UNIVERSIDADE DE SÃO PAULO FACULDADE DE CIENCIAS FARMACEUTICAS

Curso de Pós-Graduação em

Fármaco e Medicamentos

Ārea de Produção e Controle Farmacêuticos

\title{
APLICAÇÃO DO CLORETO DE TRIFENILTETRAZOLLIO NO TESTE DE LIMITE MICROBIANO EM MEDICAMENTOS E COSMÉTICOS
}

MITSUKO TABA OHARA

Tese para obtenção do grau de DOUTOR

Orientador:

Profa. Dra. TAKAKO SAlIO

São Paulo

1992 
À Prof. Dra. Takako Saito,

pela sábia orientação, constante apoio e incentivo. 
Aos meus pais

Tsuruko e Seiken,

exemplos de vida e amor.

Ao meu marido

Paulo

pela compreensão e apoio. 


\section{AGRADECIMENTOS}

À Coordenaçáo do curso de pós-graduaçáo em Fármaco e Medicamentos do Departamento de Farmácia da USP, pela atenção a nós dedicada durante todo o decorrer do curso.

Ao Prof.Dr.Reynaldo Nacco, do Departamento de Tecnologia BioquímicoFarmacêutica da Faculdade de Ciências Farmacêuticas da USP, ao Prof.Dr. José Afonso Mazzon, do Departamento de Administração da Faculdade de Economia, Administração e Contabilidade da USP e a Profa.Dra. Maria Elena Taqueda, do Departamento de Engenharia Química da Escola Politécnica da USP, pela análise estatística de resultados.

À pós-graduanda Márcia Regina S. Ferreira , pela execução de testes experimentais prévios.

À Profa.Dra. Elfriede M. Bacchi,pela tradução de textos em alemão.

À Profa.Assist. Telma Mary Sakuda e a Profa.Dra. Terezinha de Jesus Andreoli Pinto, pelas sugestões, apoio e amizade.

À bibliotecária Sra. Moema R. dos Santos, pela orientação e revisão das referências bibliográficas.

À Sra. Auriluce Missiano de Oliveira, pelos serviços de digitação e impressão.

À Sra. Márcia Vallim, pelos serviços diversos.

À todos que colaboraram na execução deste trabalho. 
MITSUIKO TABA OHARA

APLICAÇÃo DO CLORETO DE TRIFENILTETRAZÓLIO NO TESTE DE LIMITE MICROBIANO EM MEDICAMENTOS E COSMÉTICOS

COMISSÃO JULGADORA

TESE PARA OBTENÇÃO DO GRAU DE DOUTOR

TakAkE SAito

Presidente e Orientador

$\frac{\text { MAliA Tosé Vieica FonsecA }}{\text { Primeiro Examinador }}$

Becnadette Doca G. Mello Fronco

Segundo Examinador

flavio Alterthur

Terceiro Examinador

ÉLika Rosa malia kedoc

Quarto Examinador

São Paulo, 27 de $\quad 10 \quad$ de 1992. 


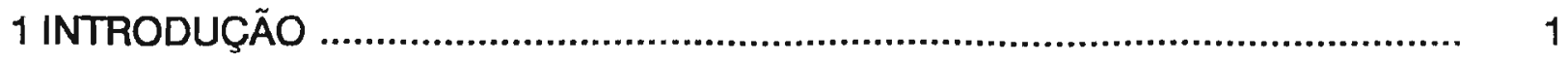

2 OBJETIVO .......................................................................................

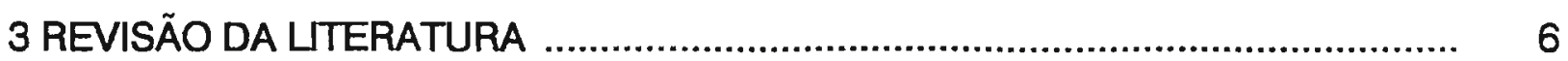

3.1 Padrão microbiano de medicamentos não estéreis .......................................... 6

3.2 Padrão microbiano de cosméticos .............................................................. 11

3.3 Avaliação da qualidade microbiana de medicamentos não estéreis e de cosméticos

3.3.1 Métodos oficiais para medicamentos não estéreis ........................................ 15

3.3.1.1 Amostragem e preparação do material .................................................... 17

3.3.1.2 Preparação de amostras ...................................................................... 20

3.3.1.3 Técnicas de contagem de microrganismos viáveis..................................... 29

3.3.2 Métodos alternativos ................................................................................. 41

3.3.2.1 Métodos por automatização de técnicas tradicionais .................................. 42

3.3.2.2 Métodos de contagem direta .............................................................. 44

3.3.2.3 Métodos de contagem baseados no metabolismo microbiano .................... 48

3.3.2.4 Métodos de bioluminescência ................................................................ 50

3.4 Compostos empregados na deteç̧ão de microrganismos .............................. 51

3.4.1 Cloreto de trifeniltetrazólio ....................................................................... 55

3.4.1.1 Aplicação ............................................................................................ 55

3.4.1.2 Mecanismo de reação .............................................................................. 61

4 MATERIAL E MÉTODOS ........................................................................... 70

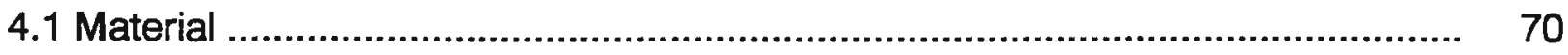

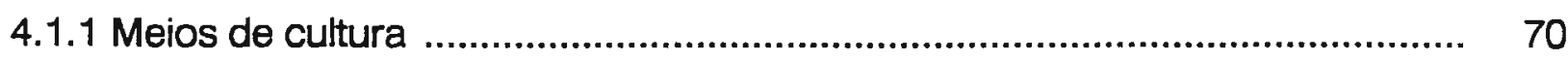

4.1.2 Reagentes ..................................................................................... 71

4.1.3 Especialidades farmacêuticas .................................................................... 71

4.1.4 Produtos cosméticos ............................................................................. 72

4.1.5 Suspensão de microrganismos padrões ……............................................ 72

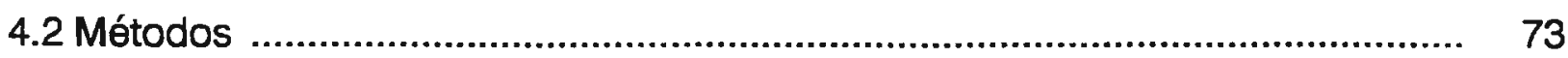


4.2.1 Preparação dos meios de cultura

4.2.2 Preparação de ágar bacteriológico a 1,0\% com trifeniltetrazólio.

4.2.3 Preparação das soluções de cloreto de trifeniltetrazólio.

4.2.4 Preparação de suspensão aquosa de hidróxido de alumínio a 6,0\%

4.2.5 Preparação de solução aquosa de hidróxido de sódio $2 \mathrm{~N}$

4.2.6 Preparação de solução fisiológica

4.2.7 Preparação da suspensão de bactérias

4.2.8 Preparação da suspensão de leveduras

4.2.9 Determinação da concentração mínima inibitória do cloreto de trifeniltetrazólio

4.2.10 Verificação da influência do inóculo, aditivos ao meio de cultura $\theta$ concentração do cloreto de trifeniltetrazólio no desenvolvimento da coloração .......

4.2.11 Comparação entre a técnica de tubos múltiplos com sub-cultura e emprego de cloreto de trifeniltetrazólio na detecção de microrganismos viáveis

4.2.12 Detecção de Candida albicans pela técnica de tubos múltiplos com sub-cultura e pela redução do cloreto de trifeniltetrazólio em meio alcalinizado .......

4.2.13 Avaliação da atividade inibitória do polissorbato 20 e 80 e da lecitina de soja adicionados ao meio de caseína-soja

4.2.14 Determinação da concentração mínima eficaz do cloreto de trifeniltetrazólio para revelação de colônias bacterianas

4.2.15 Determinação da concentração mínima eficaz do cloreto de trifeniltetrazólio para revelação de colónias de leveduras

4.2.16 Determinação da concentração mínima eficaz do cloreto de trifeniltetrazólio para revelação de colónias de bactérias desenvolvidas em meio com opacidade

4.2.17 Determinação da concentração mínima eficaz do cloreto de trifeniltetrazólio para revelação de colônias de $C$. albicans desenvolvidas em meio com opacidade

4.2.18 Comparação entre as técnicas de tubos múltiplos com sub-cultura e de semeadura em profundidade mediante revelação das colônias com cloreto de trifeniltetrazólio em amostras de produtos comerciais, inoculadas com microrganismos padrões

4.2.19 Avaliação da eficiência do cloreto de trifeniltetrazólio aplicado ao método de tubos múltiplos e semeadura em profundidade para determinação de carga microbiana contaminante em amostras comercializadas 
5 RESULTADOS

6 DISCUSSÃO

6.1 Considerações gerais

6.2 Concentração mínima inibitória do cloreto de trifeniltetrazólio

6.3 Infiuência da concentração de cloreto de trifeniltetrazólio do inóculo e de aditivos ao meio de cultura no desenvolvimento da coloração

6.4 Comparação entre a técnica de tubos múltiplos com sub-cultura e emprego de cloreto de trifeniltetrazólio na detecção de microrganismos

6.5 Determinação da concentração mínima eficaz de cloreto de trifeniltetrazólio para revelação de colónias bacterianas e de leveduras

6.6 Avaliação da eficiência de cloreto de trifeniltetrazólio aplicado aos métodos de tubos múltiplos e de semeadura em profundidade para determinação de carga microbiana em amostras de produtos comerciais

7 PROPOSTA DE MÉTODO ANAĹTICO OFCIAL PARA O TESTE DE UMITE MICROBIANO EM MEDICAMENTOS HIDROINSOLÚVEIS FORTEMENTE OPALESCENTES E COM BAIXA CARGA MICROBIANA (NÃO MAIS QUE $10^{2} \mathrm{UFC} / \mathrm{mL}$ ) 170

7.1 Método para contagem de microrganismos aeróbios em medicamentos e cosméticos, na forma de suspensão ou emulsão pela técnica de tubos múltiplos

7.2. Método para contagem de microrganismos aeróbios em medicamentos e cosméticos, na forma de suspensăo ou emulsão pela técnica de semeadura em profundidade

8 CONCLUSÕES

9 REFERÊNCIAS BIBLIOGRÁFICAS 174

RESUMO 209

ABSTRACT 211 


\section{INTRODUÇÃO}

$\mathrm{Na}$ elaboração de um medicamento ou de cosmético, cujo desenvolvimento envolve desde o seu projeto até a produção do mesmo, a garantia de qualidade deve ser aspecto primordial a ser considerado para assegurar a eficácia, inocuidade e a aceitabilidade do produto pelo paciente ou consumidor.

A qualidade microbiana é um dos atributos essenciais para 0 desempenho desses produtos, principalmente quanto à segurança e aceitabilidade, pois a presença de microrganismos, a partir de determinado nível, implica na deterioração dos mesmos e ainda, dependendo da espécie, acarreta sério risco ao usuário.

Os métodos farmacopêicos de avaliação da qualidade microbiana diferem em função da classificação dos medicamentos em produtos estéreis e não estéreis. Para aqueles do primeiro grupo é exigido o testę de esterilidade, ensaio limite, cujo padrão de exigência recai na probabilidade de $10^{-6}$. Para os não estéreis, a avaliação consiste na determinação estimativa ou quantitativa de microrganismos contaminantes viáveis e comprovação de ausência de alguns patogênicos específicos. Portanto, igualmente se refere ao ensaio limite, com nível de tolerância diferente em relação à primeira classe de medicamentos.

Os métodos oficiais para determinação de microrganismos contaminantes viáveis em medicamentos não estéreis, extensivos aos cosméticos, são aqueles convencionalmente utilizados para contagem de microrganismos viáveis. Esses defrontam-se com certas restrições em função da natureza da amostra, o que acaba limitando sua aplicação ampla a todos os tipos de amostras. A escolha do método a ser adotado está em função das características da forma farmacêutica e do nível da carga microbiana contaminante.

O padrão microbiano internacional, estabelecido na década de 70 , sugere que o limite do número de bactérias aeróbicas mesofilicas seja de $10^{2} / \mathrm{g}(\mathrm{mL})$ 
para produtos de uso tópico e $10^{3} / \mathrm{g}(\mathrm{mL})$ para outros. Porém, não consta nas farmacopéias algum padrão comum a todos os medicamentos não estéreis. Todavia, aqueles especificados para algumas matérias-primas e produtos indicam a tendência para o limite menor que $10^{2} / \mathrm{g}(\mathrm{mL})$. Esta orientação verifica-se, também, para os cosméticos.

Na avaliação dessas amostras, a fim de comprovar a conformidade para com tais padrões, o método analítico deve ser, por sua vez, compatível com as características da amostra, inerentes à forma farmacêutica.

Para produtos líquidos, a filtração em membrana é considerado método de escolha, pois permite análise de amostras com baixa carga contaminante, com vantagem da eliminação dos princípios ativos que poderiam acarretar atividade biostática. No entanto, esse método não é aplicavél para todos os líquidos, sendo possível apenas para amostras compatíveis com o sistema de filtração esterilizante, ou seja, soluções ou sólidos solúveis em fluidos aquosos ou em solventes orgânicos biocompatíveis.

A filtração em membrana é particularmente útil para se testar amostras com carga microbiana muito pequena, como por exemplo a água destilada a ser utilizada na preparação de soluções parenterais de grande volume, em que o limite recomendado para contaminante bacteriano é de no máximo 25 UFC/100 mL.

Apesar de ser método mais adequado para se testar amostras dessa natureza, uma vez que pode filtrar grandes volumes, esse também apresenta alguns problemas, tais como a dificuldade na visualização de colônias transparentes ou muito pequenas, nacessitando de recurso complementar para se efetuar a contagem.

Outro método quantitativo, convencionalmente empregado para análise de medicamentos e cosméticos, é a contagem em meio sólido. Essa técnica apresenta limitação para amostras cuja característica prejudica a transparência do meio de cultura ou contém partículas insolúveis que dificultam a distinção entre essas e 
colônias.

As farmacopéias preconizam a semeadura da amostra a partir da mesma diluída de 10 vezes. Quando a turvação do produto impede a contagem de colónias, por não apresentar transparência do gel, a orientação é para utilização de diluições maiores.

Para maior precisão do método recomenda-se que o resultado seja obtido a partir de dados experimentais, cujo número de colónias tenha sido de 30 a 300 por placa. Consequentemente, essa técnica é aplicável para amostras com carga mínima de $1,5 \times 10^{2} \mathrm{UFC} / \mathrm{g}(\mathrm{mL})$, inoculando-se $2 \mathrm{~mL}$ da diluição $10^{-1}$, pois para volumes inferiores o número de colónias por placa será menor que 30 , o que é considerado pouco preciso. Portanto, a técnica de ágar fundido, nas condições estabelecidas para a sua validade, não pode ser aplicada para amostras que se enquadram às exigências especificadas em não mais que $10^{2} / \mathrm{g}(\mathrm{mL})$ ou àquelas que provocam opacidade do gel ou ainda por se tratarem de suspensões particuladas.

$\mathrm{Na}$ análise de amostras em que tanto a filtração como a contagem em placas não são aplicáveis, a orientação consiste na utilização do método de tubos multiplos em meio líquido (número mais provável). Entretanto, esse método é estimativo, além de não permitir detecção fácil e direta do crescimento microbiano, quando testadas amostras diferentes de soluções, como suspensões ou algumas emulsões. Para a diferenciação da turvação inerente à natureza da amostra com aquela resultante do crescimento microbiano, recorre-se à sub-cultura, que representa tempo adicional na obtenção de resultados.

Face às limitações dos métodos convencionais de determinação do número de microrganismos contaminantes viáveis em diferentes tipos de amostras, faz-se necessária a adaptação dos mesmos a fim de padronizar outros, como recursos alternativos, que sejam mais rápidos e eficazes.

Alguns compostos que se modificam, tornando-se coloridos ou 
fluorescentes em presença de organismos, são empregados em microbiologia para diferentes finalidades.

O cloreto de 2,3,5-trifeniltetrazólio (TTC) é substância incolor que quando reduzido à formazano é de coloração vermelha. Esse corante tem sido utilizado em trabalhos que envolvem deteç̧ão de microrganismos viáveis, com várias aplicações, merecendo mais estudos. 


\section{OBJETIVO}

Se de um lado a influência de alguns fatores físico-químicos envolvendo a reação do 2,3,5-trifeniltetrazólio (TTC) junto ao crescimento microbiano é conhecida, do outro, a interação com variados tipos de amostras medicamentosas e cosméticas, quando da sua utilização no controle de qualidade sanitária das mesmas, deve ser melhor estudada.

O objetivo do presente trabalho foi estabelecer as condições para a aplicabilidade desse corante na detecção de microrganismos viáveis em medicamentos e cosméticos, com a finalidade de reduzir o tempo de análise, bem como possibilitar o ensaio de amostras com baixa carga contaminante, por sua vez contendo material particulado hidro-insolúvel. 


\section{REVISÃO DA LITERATURA}

\subsection{Padrão microbiano de medicamentos náo estéreis}

A qualidade microbiana de medicamentos não estéreis mereceu maior atenção por parte dos órgãos governamentais de saúde e das indústrias, após a década de 60 , quando foram relatados casos de infecção, alguns com consequências graves ou fatais, decorrentes da utilização de produtos farmacêuticos contaminados com microrganismos infecciosos 24, 66, 98, 118, 126, 135, 168, 192, 225.

Anteriormente, apenas a farmacopéia da Checolosváquia incluia o padrão microbiano para os medicamentos não estéreis, com limite de $5 \times 10^{4} / \mathrm{g}(\mathrm{mL})$ para contagem total de viáveis e ausência de contaminantes indicadores da contaminação fecal, e de outros patogênicos específicos e bolores ${ }^{42}$. Nas outras farmacopéias constavam especificações para algumas matérias-primas de origem natural, sendo a gelatina a primeira para a qual foi estabelecido o limite microbiano ${ }^{75}$, 236, 237, 238.

KALLNGS e colaboradores 118 foram considerados pioneiros nos trabalhos de qualidade sanitária de medicamentos não estéreis, quando relataram vários casos de infecção veiculados por medicamentos contaminados, em 1966, na Suécia. Esses pesquisadores, após levantamento da qualidade dos medicamentos comercializados naquele país, sugeriram o limite de $10^{2}$ bactérias $/ \mathrm{g}(\mathrm{mL})$, com ressalva de que nos casos em que esse limite não fosse possível de ser atingido, referindo-se a preparações contendo insumos de origem animal ou vegetal, comprovasse a ausência de coliformes e de outros microrganismos patogênicos que pudessem, potencialmente, estar presentes. Esse padrão foi adotado pelo Ministério da Saúde da Suécia, em 1967, tendo sido o limite quantitativo retificado para contagem total de microrganismos viáveis ou ausência de coliformes e de Salmonella sp ${ }^{230}$.

A Farmacopéia Internacional de 1970 190, apesar de não estabelecer um padrão microbiano com limites, especificava que a contaminação 
microbiana em medicamentos não estéreis deveria ser menor ou igual aos níveis permitidos para alimentos, segundo a legislação de cada país.

A nível internacional, propostas de padrão microbiano foram efetuadas pela Federação Farmacêutica Internacional (FIP) ${ }^{47}$ e pela Comissão da Farmacopéia Européia ${ }^{230}$, em 1973. As duas propostas basearam-se no risco da contaminação para o paciente em função da via de administração. Para os medicamentos de uso tópico, que não necessitavam de atender às provas de esterilidade, porém por serem preparações para aplicação em áreas mais susceptíveis à contaminaçào como pele lesada, nariz, garganta, ouvido, etc., foi recomendado o limite máximo de $10^{2}$ microrganismos viáveis $\theta$ ausência de enterobactérias por grama. Além disso, ausência de $P$. aeruginosa e $S$. aureus em $1 \mathrm{~g}(\mathrm{~mL})$ do produto. Para outras preparações, o limite estabelecido foi de $10^{3}$ e $10^{4}$ para bactérias aeróbias e $10^{2}$ para leveduras e bolores, além de ausência de $E$. coli em $1 \mathrm{~g}(\mathrm{~mL})$; em alguns casos recomenda ainda ausência de Salmonella $s p, P$. aeruginosa e $S$. aureus e tolerância de enterobactérias até $10^{2} / \mathrm{g}(\mathrm{mL})$. Quanto à tolerância para bactérias aeróbias totais, $10^{4} / \mathrm{g}(\mathrm{mL})$, refere-se ao caso de produtos com componentes que são inevitavelmente fontes de contaminação, e que tal carga não pode ser reduzida pelo processo de fabricação.

O padrão proposto pela Comissão da Farmacopéia Européia difere daquele da FIP, no tocante aos patogênicos em produtos de uso oral, não exigindo ausência de $S$. aureus e de $P$. aeruginosa.

A Sociedade Italiana de Ciências Farmacêuticas (SISF) ${ }^{62}$ sugeriu, também, padrão semelhante ao da FIP, porém menos exigente para produtos de uso tópico. O limite para essa classe de produtos quanto a carga total foi menor que $10^{2} / \mathrm{g}$ $(\mathrm{mL})$ de bactérias aeróbias mesofilicas, e o mesmo limite para a soma de bolores e leveduras; quanto aos patogênicos, exigiu ausência específica de $E$. coli/g $(\mathrm{mL})$ e não de enterobactérias. Por outro lado, para medicamentos de uso oral, o limite máximo de bactérias aeróbias foi de $10^{3} / \mathrm{g}(\mathrm{mL})$, não havendo a tolerância para $10^{4} / \mathrm{g}(\mathrm{mL})$. 
Entretanto, a restrição aos microrganismos específicos se deteve apenas na ausência de E. coli/g (mL).

O Laboratório Nacional de Saúde da França ${ }^{186}$, também, adotou o padrão sugerido pela FIP, com divergência apenas quanto aos microrganismos específicos. Esse padrão acrescentou a exigência quanto à ausência de estreptococos fecais e de clostrídios sulfito-redutores, tanto para produtos de uso tópico como para os de uso oral.

A partir dos padrões propostos pelos órgãos oficiais de saúde, dois autores sugeriram modificações, principalmente em relação aos microrganismos específicos que deveriam estar ausentes. TAGLIAPIETRA ${ }^{230}$, em 1978, sugeriu um padrão que vincula a pesquisa de microrganismos específicos à carga microbiana viável total. Quando esse número nos produtos de uso tópico, for menor que $10 / \mathrm{g}(\mathrm{mL})$ e $10^{2} / \mathrm{g}(\mathrm{mL})$ nos de uso oral, a pesquisa de patogênicos específicos restringe-se à $E$. coli; nos casos em que as cargas são superiores a esses limites, as especificações são as mesmas àquelas propostas pela SISF para os de uso tópico e às da Comissão da Farmacopéia Européia para os de uso oral. Por outro lado, a orientação de RINGERTZ e RINGERTZ ${ }^{208}$, de 1982, é contrária à do pesquisador anterior. Esses sugerem o mesmo limite da FIP quanto a carga microbiana, porém muito mais abrangente quanto aos microrganismos que devem estar ausentes. Nos produtos de uso tópico, os microrganismos que devem ser pesquisados, segundo esses autores são: $S$. marcescens, Klebisiella sp, P. putida, P. multivorans, C. perfringens, C. tetani, C. novy, Aspergillus sp e C. albicans, além daqueles recomendados pela FIP; ausência de Shigella sp e fungos produtores de toxinas são incluídos para os de uso oral.

Anteriormente, em 1972, BRUSCH ${ }^{34}$ considerava que os produtos de uso tópico deveriam ser isentos de $C$. tetani e $C$. perfringens em $0,1 \mathrm{~g}$ de amostra. Ainda em relação aos mesmos produtos, EVANS ${ }^{71}$ sugeriu, no mesmo ano, ausência de bactérias Gram negativas e de endotoxinas. 
Segundo BAIRD ${ }^{11}$, apesar da importância do controle microbiano de produtos não estéreis ter sido reconhecido há muitos anos, a implantação e aceitação dos padrões sanitários tem ocorrido lentamente. Este fato pode ser observado nas farmacopéias em que os padrões estão sendo incluídos gradativamente.

A Farmacopéia Americana é aquela que introduziu especificações de qualidade microbiana para maior número de matérias-primas e produtos. Em 1970, quando foi incluído, pela primeira vez, o número de produtos para os quais constava o limite microbiano,era de 13, 3 com especificação qunato a carga microbiana viável. Dentro dos insumos, 6 especificavam quanto à carga microbiana viável e $7 \mathrm{com}$ exigência quanto a ausência de Salmonella sp e ou $E$. coli ${ }^{34,230}$.

A National Formulary da mesma época (NF XII) também estabeleceu limites para 12 matérias-primas, porém sendo apenas $1 \mathrm{com}$ limite para contagem total de contaminantes viáveis enquanto que em todas exigia a ausência de Salmonella sp ${ }^{230}$.

Na última edição da Farmacopéia Americana (USP XXII) ${ }^{246}$, de 1990, constam 49 matérias-primas com especificação quanto a qualidade microbiana. Dessas, em 16 consta o limite de carga microbiana viável que varia de $10^{2}$ a $10^{3} / \mathrm{g}(\mathrm{mL})$ com ou sem exigência quanto à ausência de $E$. coli e/ ou de Salmonella sp em $10 \mathrm{~g}$ $(\mathrm{mL})$; no restante das monografias consta a exigência quanto à ausência de $E$. coli e ou Salmonella sp e em algumas, $S$. aureus e $P$. aeruginosa. Nessa edição foi acrescentado o limite máximo para o número de fungos, para 2 matérias-primas. Em relação aos produtos, especificações microbianos foram ampliados para 34 de uso oral e 66 de uso tópico. Para os de uso oral, em 16 configuram o limite de carga microbiana viável de no máximo $10^{2} / \mathrm{g}(\mathrm{mL})$, além de $10^{3} / \mathrm{g}$ e $400 / \mathrm{g}$, respectivamente, para as pastas de carboximetilcelulose e hidróxido de magnésio. Quanto aos microrganismos patogênicos específicos exige ausência de $E$. coli em algumas monografias e em outras, somente, Salmonella sp, ou a ausência de ambos em $10 \mathrm{~g}(\mathrm{~mL})$ de amostra. 
Para alguns produtos consta, ainda, exigência adicional para $P$. aeruginosa e $S$. aureus. Para os de uso tópico, a especificação refere-se apenas à ausência de S. aureus e de $P$. aeruginosa em $10 \mathrm{~g}(\mathrm{~mL})$, com exceção de solução otológica de benzocaína, creme de haloprogina e sulfato de polimixina B e bacitracina zinco, nas formas de aerossol e pó, para os quais estabelece o limite de número de microrganismos viáveis ${ }^{56}$.

DAVISON 56 não considera claro o critério adotado para o estabelecimento dessas especificações, uma vez que exclui alguns cremes aquosos, géis e loções, mas inclui pomadas de bases oleosas que não são, geralmente, sujeitas à contaminação microbiana. Da mesma forma, segundo o autor, não se justifica a inclusão de ausência de E. coli e Salmonella sp em solução otológica de benzocaína e creme de haloprogina.

A Farmacopéia Britânica introduziu o teste para contaminação microbiana em 1973 30. A especificação dessa edição exige ausência de microrganismos patogênicos, que são: E. coli, Salmonella sp e Pseudomonas sp. A edição de $1988{ }^{32}$ mantém, ainda, a exjgência apenas semi-quantitativa, porém com especificação para $P$. aeruginosa, $S$. aureus e enterobactérias, além daquelas citadas na edição anterior.

Na Farmacopéia Européia de $1985^{69}$ consta o limite microbiano para 18 matérias-primas com números que variam de $10^{2}$ a $10^{4} / \mathrm{g}(\mathrm{mL})$ para contagem total de aeróbios viáveis e ausência de E. coli em $1 \mathrm{~g}(\mathrm{~mL})$ e de Salmonella sp em $10 \mathrm{~g}$ $(\mathrm{mL})$. Em algumas monografias exige a ausência de enterobactérias $e$ de $P$. aeruginosa. Nessa farmacopéia consta a orientação de que o limite máximo de aceitação deve ser de 5 vezes o limite especificado. Logo, quando o limite especificado é de $10^{2} / \mathrm{g}(\mathrm{mL})$ o valor máximo para aceitação da amostra (lote) é de $5 \times 10^{2} / \mathrm{g}(\mathrm{mL})$.

O padrão adotado pela Farmacopéia Italiana de 1985 (FU IX) ${ }^{9}$ é o de 2 níveis, proposto por TAGLIAPIEIRA ${ }^{231}$, com algumas modificações. Tanto para produtos de uso tópico como oral, desde que a carga microbiana aeróbia seja menor que 10/g ( $\mathrm{mL}$ ) não há exigência para a pesquisa de microrganismos patogênicos. 
Ultrapassado esse limite as especificações diferem para os de uso tópico e oral. Para os de primeiro grupo o limite máximo de bactérias aeróbias mesófilas é de $10^{2} / \mathrm{g}(\mathrm{mL})$ e $10 / \mathrm{g}(\mathrm{mL})$ de bolores e leveduras, complementado com a ausência de $P$. aeruginosa e S. aureus em $1 \mathrm{~g}(\mathrm{~mL})$. Para os de uso oral, o limite para as bactérias é de $10^{3}$ a $10^{4} / \mathrm{g}$ $(\mathrm{mL})$ e $10^{2} / \mathrm{g}(\mathrm{mL})$ para bolores e leveduras; permite tolerância de até $10^{2} / \mathrm{g}(\mathrm{mL})$ para enterobactérias e exige ausência de $E$. coli em igual quantidade de amostra e de Salmonella sp em $10 \mathrm{~g}(\mathrm{~mL})$.

Como a $4^{a}$ edição da Farmacopéia Brasileira ${ }^{74}$ de 1988 contem apenas os métodos gerais, apesar da inclusão de procedimento para contagem de microganismos viáveis e pesquisa e identificação de patógenos, não existe especificação quanto à qualidade microbiana. Igualmente, na edição anterior também não constaram os limites para produtos não estéreis ${ }^{73}$.

A norma orientativa de controle de qualidade em hospitais regionais dos Estados Unidos, referente às matérias-primas e preparações utilizadas em hospitais, revisada em 1989, apresenta dois limites. Para matérias-primas e produtos de uso oral o limite é de $10^{2} / \mathrm{g}(\mathrm{mL})$ com o máximo de $10^{3} / \mathrm{g}(\mathrm{mL})$, enquanto que para os de uso tópico, respectivamente 10 e $10^{2} / \mathrm{g}(\mathrm{mL})$. Os patogênicos considerados indesejáveis são: S. aureus, Pseudomonas $s p$, enterobactérias e clostrídio em $1 \mathrm{~g}(\mathrm{~mL})$ e Salmonella sp em $10 \mathrm{~g}(\mathrm{~mL})$ para matérias-primas; os mesmos microrganismos, exceto clostrídios e Salmonella sp para os de uso tópico; para os de uso oral, E. coli e Salmonella sp respectivamente em $1 \mathrm{~g}(\mathrm{~mL})$ e $10 \mathrm{~g}(\mathrm{~mL})$ e tolerância de $10^{2}$ de enterobactérias ou Pseudomonas $\mathrm{sp} / \mathrm{g}(\mathrm{mL})$ de amostra 56.

\subsection{Padrão microbiano de cosméticos}

Igualmente aos medicamentos, os cosméticos também foram responsáveis por infecção, principalmente por meio indireto através dos cosméticos utilizados pela equipe médica hospitalar 10, 99, 160, 222, 249 . Os casos de infecção diretamente relacionados com o uso de cosméticos referem-se àqueles decorrentes dos produtos contaminados e aplicados na àrea dos olhos e de talco em recém- 
nascidos $99,205,248,260$.

Em relação aos cosméticos não existem padrões oficiais, mas apenas especificações que devem ser adotados como normas de orientação.

Nos Estados Unidos, Food and Drug Administration (FDA) não estabeleceu um padrão microbiano para cosméticos, no entanto declara na Seção 601 que "um cosmético será considerado adulterado se:

a) contiver qualquer substância venenosa ou nociva que possa provocar danos ao usuário, sob condições de uso prescritas no rótulo ou em condições normais de uso;

b) consiste inteira ou parcialmente de qualquer sujidade ou substância deteriorada ou decomposta;

c) tiver sido preparado, embalado ou transportado em condições sanitárias não adequadas que se possam tornar contaminados por sujidades ou pelo qual possa provocar danos para saúde".

O FDA interpreta a adulteração, baseada no ítem a, como sendo presença de microrganismos infecciosos como $P$. aeruginosa e $S$. aureus e no item b, interpretando a carga excessiva de microrganismos como sujidade ${ }^{144}$.

A Cosmetic Toiletry Fragrance Association (CTFA) dos Estados Unidos estabeleceu, em 1973, o limite de $5 \times 10^{2}$ UFC/g (mL) de microrganismos viáveis para produtos utilizados para área dos olhos e para bebês e $10^{3} \mathrm{UFC} / \mathrm{g}(\mathrm{mL})$ para outros cosméticos ${ }^{231}$.

A diretriz da Comunidade Económica Européia quanto à qualidade microbiana em cosméticos estipula, no seu artigo 2, que "produtos cosméticos colocados no mercado da Comunidade não devem ser passíveis de causar dano para saúde humana, quando são aplicados sob condições normais de uso". Entretanto, face às necessidades de definição quanto aos limites de tolerância foi nomeado um sub- 
grupo para estabelecer especificações. A proposta desse grupo consistiu no plano de 3 classes, com um limite de aceitabilidade, outro para rejeição e o intermediário entre esses dois números, considerado de aceitabilidade com reserva. O limite aceitável foi de $10^{3} / \mathrm{g}(\mathrm{mL})$ e o de rejeição, $10^{4} / \mathrm{g}(\mathrm{mL})$. Nos casos em que nehuma amostra apresentar carga acima de $10^{4} / \mathrm{g}(\mathrm{mL})$ e no máximo 2 das 5 amostras estiver entre $10^{3}$ a $10^{4} / \mathrm{g}(\mathrm{mL})$ o lote será considerado aceitável; quando o número de amostras na faixa intermediária exceder de 2 será recomendado pesquisa de $P$. aeruginosa, $S$. aureus e C. albicans em $1 \mathrm{~g}$ do produto. Evidentemente, se todas as amostras apresentarem carga abaixo do limite de aceitabilidade o lote será aprovado e da mesma forma, se qualquer amostra estiver com carga acima de $10^{4} / \mathrm{g}(\mathrm{mL})$ será rejeitado. Para os produtos da área dos olhos ou para bebês, o limite intermediário estabelecido foi de 1 em 5 amostras e para patogênicos, ausência em $10 \mathrm{mg} 226$.

As normas de orientação da Cosmetic and Toiletry Manufacturers Association da Austrália introduziram limites mais rígidos, pois a tolerância para microrganismos viáveis é de $10^{2} \mathrm{UFC} / \mathrm{g}(\mathrm{mL})$, exceto em preparações nas quais o componente de maior proporção é mineral, onde a carga permitida é de até $10^{3} \mathrm{UFC} / \mathrm{g}$ $(\mathrm{mL})$. Para produtos da área dos olhos o limite especificado foi de $10 \mathrm{UFC} / \mathrm{g}(\mathrm{mL})$. Em relação aos microrganismos específicos, esse guia fornece a relação de organismos e aqueles a serem pesquisados devem ser selecionados pelo produtor, por exclusão, com base na sua experiência, que indica aqueles mais prováveis de serem contaminantes indesejáveis. Os microrganismos para os quais constam métodos de isolamento e identificação nesse guia são: S. aureus, E. coli, Salmonella sp, Pseudomonas sp, C. albicans e clostrídios ${ }^{226}$.

$\mathrm{Na}$ Inglaterra, a Toilet Preparations Federation (TPF) sugere o limite menor que $10^{3} \mathrm{UFC} / \mathrm{g}(\mathrm{mL})$ para bactérias aeróbias, leveduras e bolores. Os produtos destinados à área dos olhos e para os bebês devem ser enquadrados ao limite de tolerância de menor que $10^{2} \mathrm{UFC} / \mathrm{g}(\mathrm{mL})^{226}$.

No Brasil, o Grupo de trabalho de cosméticos reunidos no Instituto 
Nacional de Controle de Qualidade em Saúde da Fundação Oswaldo Cruz (INCQS/FIOCRUZ) 146 recomenda limite máximo de $50 \mathrm{UFC} / \mathrm{g}(\mathrm{mL})$ de microrganismos viáveis totais, quando se referem aos cosméticos da área dos olhos; $10^{2} \mathrm{UFC} / \mathrm{g}(\mathrm{mL})$ para os de uso infantil, para área genito-urinária e para loções e cremes com base aquosa, além de produtos que entram em contacto com mucosas e aqueles que podem ser inalados; $10^{3} \mathrm{UFC} / \mathrm{g}(\mathrm{mL})$ para demais cosméticos. Para todos os produtos recomendam a ausência de $P$. aeruginosa, $S$. aureus enterobactérias em $1 \mathrm{~g}(\mathrm{~mL})$ e com ressalva para ausência de clostrídios quando se tratar de pós.

\subsection{Avaliação da qualidade microbiana de medicamentos não estéreis e de cosméticos}

Os levantamentos da qualidade microbiana de medicamentos não estéreis e de cosméticos foram realizados na década de 60, utilizando-se de métodos baseados naqueles estabelecidos para análise de água e alimentos, uma vez que não havia método padronizado para essa classe dos medicamentos $118,208$.

Os métodos para determinação de pureza microbiana descritos nas farmacopéias em vigor, para análise de medicamentos não estéreis, são técnicas microbiológicas convencionalmente empregadas 2, 3, 32, 60, 68, 74, 150, 246 . Consistem em técnicas de preparação da amostra, sua semeadura em meios para contagem de microrganismos viáveis e procedimentos para detecção de bactérias patogênicas 32 , $60,74,246$.

O resultado do teste para determinação de microrganismos contaminantes na amostra depende da técrica de amostragem, da eficiência quanto à neutralização de agentes antimicrobianos do produto e da sensibilidade do método de contagem empregado. A pesquisa de patogênicos depende, ainda, da escolha dos meios de recuperação de microrganismos debilitados, visando seletividade. Evidentemente que se deve considerar a competência e a precisão dos analistas, uma vez que esses fatores são fundamentais, influindo em menor ou maior grau nos 
resultados 12,82

\subsubsection{Métodos analíticos oficiais para medicamentos não estéreis}

Os métodos para análise microbiológica de matérias-primas e medicamentos não estéreis foram introduzidos nas farmacopéias e compêndios oficiais a partir da década de 70, com exceção da Farmacopéia da Checolosváquia, que já exigia o teste em 1954 30, 43, 68, 74, 242.

Nos Estados Unidos os procedimentos gerais para execução dos testes foram apresentados pela primeira vez, na $18^{\mathrm{a}}$ edição da Farmacopéia Americana (USP XVIII) em 1970, enquanto que na Inglaterra, em 1973 30, 242.

Anteriormente, os métodos de avaliação da qualidade microbiana constavam, especificamente em monografias de algumas matérias-primas de origem natural $75,236,237,238,239,240,241$. A gelatina foi a primeira para a qual foi descrito 0 método de análise bacteriológica na Farmacopéia Americana (USP XII) ${ }^{236}$, em 1942 , com procedimentos para contagem de bactérias e pesquisa de $E$. coli. Nas edições posteriores o teste foi incluido, também, em monografias de outras matérias-primas de origem natural $237,238,239,240,241$. A Farmacopéia Brasileira ${ }^{75}$, em 1959, a exemplo da americana em vigor ${ }^{239}$, apresentou o teste para a gelatina e levedura seca, com descrição da técnica de contagem de bactérias e pesquisa de coliformes para o primeiro insumo e a contagem de bactérias e bolores para o segundo.

Nas farmacopéias de alguns paises da Europa, vigentes na década de 60, não houve menção aos testes microbiológicos, nem mesmo nas monografias das matérias-primas citadas anteriormente ${ }^{76,189}$. Apesar disso, nas décadas de 60 e 70, os órgãos oficiais de Saúde Pública da Europa descreveram os métodos que foram empregados para análise de medicamentos não estéreis, com a finalidade de se conhecer a situação da qualidade microbiana desse grupo de produtos 47,117,182. Entretanto, estes procedimentos foram incluidos, somente nas farmacopéias editadas mais recentemente, na década de $80^{60,68,74}$. Na Itália e Alemanha os métodos gerais 
para controle de qualidade microbiológica dessa classe de medicamentos consta, respectivamente, nas edições de 1985 e 1986 9,60. Mesmo nos compêndios internacionais, como a Farmacopéia Européia de $1980^{67}$ e a Internacional de $1979{ }^{235}$, não fazem referência aos testes, apesar de os mesmos terem sido apresentados pela OMS ${ }^{263}$, em 1969 e pela FIP, em 1976 47. Em 1983 a Farmacopéia Européia incluiu essa metodologia 68. Na Internacional de 198972 constam a especificações e as modificações dos métodos gerais fisico-químicos, publicados em 1979, porém não fazem referência a métodos microbiológicos para os não estéreis.

Acompanhando a tendência internacional, no Brasil, a metodologia geral foi descrita somente na $4^{8}$ edição da Farmacopéia Brasileira, de $1988^{\mathbf{7 4}}$.

Os métodos oficiais para análise de medicamentos não estéreis consistem na determinação quantitativa de microrganismos viáveis e/ou na comprovação de ausência de microrganismos patogênicos ou oportunistas, numa determinada tomada de ensaio, que podem representar risco à saúde do consumidor $32,47,60,62,68,74,246$.

A USP XVIII 245 introduziu o teste de limite microbiano com métodos para contagem total de microrganismos aeróbios além do isolamento e identificação de $S$. aureus, $P$. aeruginosa, Salmonella sp e E. coli. Edições posteriores 243, 244, 245 não apresentaram modificações a não ser na USP XXII ${ }^{246}$ em que foi acrescentada a contagem combinada de bolores e leveduras.

A norma britânica que configurou inicialmente na BP 73, não sofreu alterações na de $1980^{30,31}$. Entretanto, na última, de $1988^{32}$, houve modificações pois, exige ausência de $P$. aeruginosa e $S$. aureus, mantendo as espécies anteriormente discriminadas como indesejáveis ( $E$. coli e Salmonella sp ). Inclui também, a técnica para contagem de microrganismos viáveis, com diferenciação para bactérias e fungos, além de enterobactérias e outras Gram-negativas. Apesar dessa técnica analítica, não há exigência de limite para contaminantes viáveis totais em monografias. Esse método geral é a mesma da Farmacopéia Européia de $1983^{68}$, que 
por sua vez é basicamente o mesmo apresentado pela FIP ${ }^{47}$, em 1976. A Farmacopéia Britânica inclui justificativas sobre a reprodução do teste da Européia, de modo a atender a conveniência dos usuários que seguem os padrões da segunda, uma vez que aquí são exigidos limites de carga contaminante viável total em algumas monografias $32,69$.

Os métodos apresentados nas últimas edições das farmacopéias em vigor são basicamente semelhantes entre si. Alguma particularidade diz respeito à determinação quantitativa de enterobactérias e outras Gram-negativas, como configura na BP $88^{32}$ e DAB $9{ }^{60} \theta$ a inclusão do método para anaeróbias em produtos de uso tópico na Farmacopéia Brasileira de $1988^{74}$ e especificamente de clostrídio e Clostridium perfringens na Farmacopéia Européia de $1991^{70}$.

\subsubsection{Amostragem e preparação do material}

Qualquer processo de amostragem pressupõe que os atributos de qualidade estão distribuídos de forma homogênea dentro do lote, uma vez que a sua qualidade é estimada a partir de resultados determinados em amostras retiradas do lote 12. Entretanto, os contaminantes podem não estar igualmente distribuídos em todo 0 lote do produto quando esse não estiver sob a forma de soluções aquosas. Em produto não aquoso, microrgarismos podem crescer preferencialmente na superfície do mesmo $12,215$.

Segundo International Comission on Microbiological Specifications for Foods (ICMS) ${ }^{234}$, para obtenção de amostra representativa, a técnica de amostragem ao acaso é mais adequada e mais confiável que a tentativa conciente de retirar unidades de várias partes do lote. Entretanto, quando se conhecem as fontes de variação e se sabe que o lote é potencialmente de qualidade não uniforme, permite várias amostragens, retirando determinado número de unidades do lote, consideradas sub-lotes. 
Nos códigos oficiais para análise de medicamentos constam diferentes conotações quanto à técnica de amostragem.

A Farmacopéia Americana, em sua $18^{\mathrm{a}}$ edição ${ }^{233}$, de 1970 recomendava que a tomada de ensaio deve ser proveniente de 10 unidades, sendo 1,0 g de cada frasco. Porém, a última, a $22^{\circledR}$ edição ${ }^{246}$ de 1990 não especifica o número de unidades que deve ser retirado para compor a amostra do lote. Situação idêntica ocorre com a Farmacopéia Britânica de $1988{ }^{32}$.

O procedimento da Federação Farmacêutica Internacional de 1976 47 orienta que a amostra deve ser composta de conteúdo retirado de no mínimo 4 frascos originais. Quanto a quantidade a ser retirada deve ser aquela suficiente para execução de todos os testes e se necessário, repetí-los.

Em 1968, BUHLMANN ${ }^{36}$ sugeriu o conteúdo de 3 ou mais frascos, perfazendo no mínimo $100 \mathrm{~mL}$ ou g, para produto final de líquidos aquosos e aqueles solúveis em água. Para os não filtráveis, como produtos oleosos, suspensões e preparações insolúveis em água, a amostra qde $10 \mathrm{~g}$ é composta da mesma forma.

Particular atenção é referida na Farmacopéia Brasileira de $1988^{\mathbf{7 4}}$ com relação à amostragem de produtos em processamento. Deve-se coletar 3 amostras do início, 4 do meio e 3 do fim do processo referente a um determinado lote. Os testes devem ser executados na mistura dessas unidades.

A técnica de amostragem mais detalhada foi introduzida mais recentemente, com planos de 2 e 3 classes de atributos para análise de água, alimentos e cosméticos $\mathbf{7 , 8 , 2 3 4}$. Nestes planos, a coleta da amostra é efetuada da mesma forma que no plano simples, porém cada uma é analisada separadamente e não a partir da amostra média. Isto possibilita a obtenção de maiores informações sobre o lote, permitindo adotar especificação menos rígida, baseada na possibilidade de pequena proporção das amostras estarem ligeiramente fora dos limites ${ }^{12}$.

O plano de 2 classes de atributos é utilizado para análise de água, 
estabelecendo-se que a presença de E. coli não é permitida em amostra alguma, porém no máximo 2 das 5 podem conter enterobactérias ${ }^{7}$.

No plano de 3 classes são estabelecidos 3 níveis de qualidade: plenamente aceitável, aceitável com reserva e inaceitável.

O emprego dessses planos na indústria farmacéutica tem-se restringido à testes e especificações estabelecidas para uso interno 12.

Além do plano de amostragem, outro aspecto de importância analítica é a tomada de ensaio. Quantidades de 1, 2, 5 e $10 \mathrm{~g}$ foram empregadas para análise de matérias-primas e produtos terminados $\pi 7,100,118,166,182,254,259$.

Nos métodos oficiais em vigor há um concenso para utilização de $10 \mathrm{~g}(\mathrm{~mL})$ 32, 60, 68, 74, 246. O método da Federação Farmacêutica Internacional permite a redução da tomada de ensaio para $1 \mathrm{~g}$ no caso de produtos muito caros ${ }^{47}$. Igualmente, a Farmacopéia Brasileira ${ }^{74}$ especifica a tomada de ensaio de $1 \mathrm{~g}(\mathrm{~mL})$ para o teste de contagem total de microrganismos viáveis pelo método de tubos múltiplos, em amostras líquidas.

A Food and Drug Administration (FDA), nos procedimentos para análise de cosméticos, estabelece a utilização de $10 \mathrm{~g}(\mathrm{~mL})$, porém permite tomadas de ensaio menores, quando o volume de cada frasco é inferior a $10 \mathrm{~g}(\mathrm{~mL})$. Nestes casos recomenda a utilização de todo o conteúdo do frasco ${ }^{141}$.

O Association of Official Analytical Chemists (AOAC) ${ }^{5}$, para contagem de bactérias em cosméticos, estabelece tomada de ensaio de $50 \mathrm{~g}$ para a preparação da diluição 1:10. Exceção é feita para líquidos, pois, volumes de $1 \mathrm{~mL}$ podem ser semeados diretamente ou após diluição de $1 \mathrm{~mL}$ em $9 \mathrm{~mL}$ de fluido diluente. 


\subsubsection{Preparação das amostras}

A precisão dos métodos de detecção de microrganismos viáveis, utilizando meios de cultura, depende fundamentalmente da preparação da amostra, para que os contaminantes presentes possam estar em contacto íntimo com os mesmos, possibilitando o acesso aos nutrientes ${ }^{254}$.

Os procedimentos para preparação da amostra dependem da sua natureza, de forma a compatibilizá-los com a técnica de contagem a ser aplicada.

Os métodos oficiais de contagem de microrganismos viáveis preconizam a preparação da amostra de modo a obter solução, suspensão ou emulsão correspondente à diluição 1:10 em diluentes biocompatíveis. Diluições posteriores para adequação do número de microrganismos com o método de contagem também são efetuadas com os mesmos fluidos $32,60,68,74,246$.

A Farmacopéia Americana XXII ${ }^{246}$ recomenda que o tratamento a ser empregado seja apropriado para as características físicas da amostra, de forma a obter soluções ou suspensões adequadas para o teste a ser executado e que, por sua vez, não altere o número e o tipo de microrganismos originalmente presentes. Observação semelhante consta no método da FIP ${ }^{47}$.

A preparação de amostras sob a forma de soluções, suspensões aquosas ou sólidos solúveis em água consite na diluição direta, sem qualquer outro tratamento.

Os aerossóis necessitam de tratamento específico para se efetuar a tomada de ensaio. Nos métodos oficiais a técnica descrita recomenda 0 congelamento do produto na sua embalagem em gelo sêco e alcool e posterior violação do material de acondicionamento para evaporação do propelente à temperatura ambiente ${ }^{62,74}$. Para cosméticos, o FDA ${ }^{141}$ recomenda o direcionamento dos jatos da amostra diretamente no diluente, préviamente pesado. 
Entre líquidos biocompatíveis, as soluções como água peptonada a 1,0\%, caldo nutriente, caldo lactosado, solução fisiológica tamponada pH 7,0 e tampão fosfato $\mathrm{pH} 7,0$ contendo $0,1 \%$ de peptona foram empregados ou recomendados como diluentes na análise microbiológica de medicamentos e cosméticos 37, 118, 125, 166, 254.

Nos métodos oficiais o diluente de escolha recaiu em tampão fosfato $\mathrm{pH} \mathrm{7,2} \mathrm{ou} \mathrm{7,0,} \mathrm{contendo} \mathrm{ou} \mathrm{não} \mathrm{outros} \mathrm{componentes} \mathrm{5,} \mathrm{74,} \mathrm{141,} \mathrm{246.} \mathrm{A}$ adequacidade da solução tampão pH 7,2 baseia-se no trabalho de BUTTERFIELD ${ }^{39}$ que ao analisar 6 diluições na contagem de bactérias em águas de superfície verificou que essa solução e a mesma contendo alguns sais foram aquelas que melhor mantiveram a viabilidade dos microrganismos até 30 minutos de contato. Por outro lado, o contacto com água destilada por igual período provocou a redução do número inicial em $62,0 \%$.

FERREIRA e FREITAS $\pi$, também, concluiram que dos vários diluentes estudados para análise de talco, a solução de salina com tampão fosfato foi aquela que melhor promoveu a recuperação de microrganismos. Entretanto, OBLINGER e KENNEDY ${ }^{169}$ não verificaram diferença estatisticamente significativa entre água peptonada a 0,1\% e 0,5\%, estudadas como diluentes de vários alimentos. No entanto, observaram que na média, os valores obtidos foram maiores quando da utilização da solução tampão pH 7,2 e menores com água destilada.

$\mathrm{Na}$ análise dos resultdos obtidos no estudo colaborativo para o leite, HUHTANEN e colaboradores ${ }^{105}$ não observaram evidências da superioridade da água tamponada $\mathrm{pH}$ 7,2 em relação à água destilada.

Segundo MAC LEOD e colaboradores ${ }^{143}$ a razão da diminuição da viabilidade dos microrganismos em água destilada é decorrência da presença de ions $\mathrm{Cu}^{+2}$, que é tóxica, principalmente para os debilitados em função de algum processo. A comprovação desse fato foi pelo teste realizado com água bidestilada utilizando materiais de vidro, ocasião em que não observaram o efeito tóxico. 
Ainda, com vistas à busca de diluente adequado para análise da contaminação em alimento, STRAKA e STOKES ${ }^{228}$ concluiram que a redução no número de viáveis em amostra diluida com água tamponada foi menor que em água destilada e em solução fisiológica. Porém, não foi considerada eficiente uma vez que verificaram redução de 20 a $30 \%$ em 20 minutos de contato, chegando à $80 \%$ em 1 hora. Segundo esses autores a adição de peptona na concentração de $0,1 \%$ promoveu a proteção dos microrganismos durante 1 hora, desde que $\circ \mathrm{pH}$ estivesse na faixa de 6,0 a 7,3. O problema da adição de peptona, em contraposição, é a multiplicação de microrganismos nesse meio quando em contato por período de 2 horas.

O auxílio da peptona na recuperação de microrganismos debilitados foi, também, observado por BOWMAN 27 no levantamento da qualidade microbiana efetuado em antibióticos.

Segundo KOLLING e SCHAPOVAL ${ }^{125}$, na determinação do número de microrganismos contaminantes em algumas emulsões cosméticas, o número obtido foi maior com a utilização de caldo lactosado como liluente, quando comparado aquele obtido com diluição da amostra em solução salina peptonada tamponada $\mathrm{pH} 7,0$.

A American Public Health Association (APHA), nos métodos para análise microbiológica para alimentos e para laticínios, adota a solução tamponada de BUTTERFIELD 19, 39, 85. Segundo BELL e colaboradores 19 a manutenção dessa solução justifica-se pela sua equivalência com outros diluentes e também, em função da falta de evidências significativas para a sua substituição.

A Farmacopéia Americana XXII ${ }^{246}$, também, indica como diluente para medicamentos não estéreis a solução tampão pH 7,2 ou caldo caseína-soja . 0 mesmo fluido é sugerido no método da AOAC ${ }^{5}$ para diluição de cosméticos, na avaliação da qualidade microbiana dos mesmos. 
BUHMAN ${ }^{36}$ recomenda a solução salina tamponada com $0,1 \%$ de peptona. Esse diluente foi adotado pela FIP 47 e posteriormente pelas Farmacopéias Britânica de $1988^{32}$ e Alemã de $19866^{60}$.

A Farmacopéia Brasileira ${ }^{74}$ define um diluente para cada grupo de produtos de acordo com as características físicas dos mesmos. São empregadas água destilada, solução tampão pH 7,2, caldo nutriente, solução aquosa de peptona a 0,1\% e o meio mais rico denominado "caldo de enriquecimento".

A diluição da tomada de ensaio em alguns dos diluentes aquosos anteriormente comentados pode resultar em misturas homogêneas, sendo nesse último caso com formação de supensões ou emulsões. Em tais situações recomendase o emprego de agentes tensoativos $32,47,60,246$. Esses compostos são geralmente adicionados nos diluentes de amostras com base oleosa como emulsões $A / O$ ou O/A $32,36,47,60,246$.

Para preparações de pós ou sólidos de difícil molhabilidade, 0 tensoativo é adicionado diretamente na amostra, de forma a se obter, pela homogeneização, mistura pastosa que facilita a diluição com o fluido aquoso, resultando dispersão mais estável ${ }^{5,32,47}$. As concentrações de polissorbatos 20 e 80 recomendados são de 0,1, 4,0, 5,0 e 10,0\% ${ }^{32,47,60,71,246 .}$

A Farmacopéia Brasileira 4a edição ${ }^{74}$ indica, além desses, o tetradecil sulfonato de sódio para dispersão de cremes e pomadas.

Segundo FERREIRA e FRETTAS $\pi$ o polissorbato 80 foi o mais eficiente entre os agentes umectantes estudados, seguido de citrato de sódio e monoestearato de glicerila, quando efetuaram análise microbiológica do talco.

Para amostra em que a diluição em fluido contendo polissorbato não é eficiente, BUHLMANN ${ }^{36}$ sugere a execução do teste na porção aquosa, após separação das fases. 
MC CONVILLE e colaboradores 152 não obtiveram resultados satisfatórios na preparação de amostras de cosméticos lipófilos anidros mediante o emprego de polissorbato, segundo o método recomendado por TENENBAUM ${ }^{232}$, que sugere a dispersão da amostra com igual volume de polissorbato 80 e diluição da mistura com água peptonada. Segundo os pesquisadores, embora a dispersão seja homogênea, ocorre a separação das fases imediatamente após adição do diluente. A sugestão dos mesmos consiste no emprego da associação de polissorbato $60 \mathrm{com}$ monooleato de sorbitan (Arlacel 80), pois o primeiro apresenta características hidrófilas enquanto que o segundo, propriedades hidrófobas. Orientação semelhante consta no método do FDA ${ }^{141}$ para análise de cremes e produtos contendo bases oleosas, pois recomenda a dispersão da amostra em óleo mineral, antes da adição de polissorbato para favorecer a formação de emulsão.

Em alguns produtos de base oleosa, somente pela adição de tensoativos, não se obtem dispersão homogênea. Nesses casos a mistura deve ser submetida ao aquecimento, em banho de água, que varia de 40 a $48^{\circ} \mathrm{C} 5,32,36,74,118$, 246.

Orientação complementar consta da Farmacopéia Brasileira IV ${ }^{\mathbf{7 4}}$, que inclui a dissolução da amostra em miristato de isopropila, previamente aqucido a $45-48^{\circ} \mathrm{C}$, para posterior filtração em membrana. A técnica é basicamente a mesma daquela descrita para o teste de esterilidade, na Farmacopéia Ameicana de $1985^{245}$, com modificações quanto à subdivisão de amostras em 6 porções de $1 \mathrm{~g}$, dissolvidas isoladamente em $100 \mathrm{~mL}$ de solvente.

O aquecimento é recurso empregado para preparação de amostras de outros tipos' além daquelas de base oleosa.

A dissolução da gelatina e de cápsulas gelatinosas vazias é obtida com auxilio de aquecimento. Para a primeira a Farmacopéia Brasileira IV ${ }^{\mathbf{7 4}}$ preconiza 0 emprego de água aquecida a $48^{\circ} \mathrm{C}$ e manutenção a $45^{\circ} \mathrm{C}$ durante 30 minutos; para cápsulas, o procedimento recomendado é a dissolução em tampão pH 7,2 aquecido a 
45-48 C. BUOGO e RATT ${ }^{37}$ sugerem agitação durante 4 horas a temperatura ambiente e 1 hora a $45^{\circ} \mathrm{C}$, para dissolução das cápsulas.

Segundo FERREIRA e FREITAS 77 o número de microrganismos recuperados foi maior quando foi adotado aquecimento da suspensão de amostras de talco em diluente. A hipótese dos autores para o resultado obtido é o favorecimento da remoção de bactérias aderidas às partículas.

A Farmacopeia Americana XXII ${ }^{246}$ recomenda que a temperatura para preparação das amostras não deve ultrapassar $45^{\circ} \mathrm{C}$, entretanto, orientação para temperatura de $48^{\circ} \mathrm{C}$ consta na Farmacopéia Brasileira ${ }^{\mathbf{7 4}}$.

Quanto ao tempo máximo em que a amostra pode permanecer a essas temperaturas, a Farmacopéia Britânica ${ }^{32}$ e a Farmacopéia Alemã ${ }^{60}$ limitam para 30 minutos.

$\mathrm{Na}$ avaliação microbiológica de medicamentos e de cosméticos, outro fator que pode influir no resultado é a presença de agentes antimicrobianos ou de sistemas conservadores. Para evitar resultados falsos, os métodos oficiais em vigor ${ }^{32}$, $60,68,74,246$ recomendam a validação do método para cada tipo de amostra, tanto para contagem de microrganismos viáveis como para pesquisa de patogênicos. 0 procedimento consiste na execução do teste com amostra propositalmente inoculada com microrganismos padrões. Para o método de contagem de viáveis o número de inóculo é da ordem de 100 células. As Farmacopéias Brasileira ${ }^{74}$, Britânica ${ }^{32}$, Alemã 60 e a Européia ${ }^{68}$ recomendam o teste com S. aureus, B. subtilis, E. coli e C. albicans. Nos trabalhos realizados na Dinamarca a escolha dos microrganismos foi dirigida em função da via de administração. Para os de uso tópico foram inoculados S. epidermidis, Rodothorula rubra e Clostridium butyricum e para os de uso oral, $S$. aureus e $C$. albicans 141, 252.

Segundo BRUCH ${ }^{34}$, apesar da validação do teste, não se conhece a sensibilidade do método, pois o comportamento de microrganismos que se 
desenvolvem naturalmente em sistemas com conservantes ou substâncias antimicrobianas pode ser diferente daqueles inoculados, por serem esses cepas de laboratório.

Uma vez verificada a atividade inibidora da amostra, o método a ser aplicado deve ser testado, a fim de garantir a eliminação de tal influência e com isso evitar resultado falso-negativo.

Os recursos disponíveis são a filtração da amostra em membranas de 0,45 $\mu \mathrm{m}$ quando isso é possível, ou ainda submeter à diluição além da concentração mínima inibitória, ou inativação dos componentes antimicrobianos através da adição de substâncias neutralizantes $32,60,68,74,215,246$.

Os conservantes são os principais agentes responsáveis pela atividade inibitória de crescimento microbiano em produtos líquidos semi-sólidos. Para a neutralização desses compostos os polissorbatos 20 e 80 são recomendados pelos códigos oficiais $32,60,68,73,215,246$. A escolha desses compostos é justificada pela capacidade de neutralização da atividade antimicrobiana de alguns conservantes mais utilizados em medicamentos e em cosméticos como clorobutanol, clorhexidina, cresóis, compostos de amônio quaternário, ácido sórbico, fenóis e principalmente os parabenos $^{12,23, \quad 179,193,195,215,257 .}$

Segundo PATEL e KOSTENBAUDER ${ }^{179}$, a adição de $5 \%$ de polissorbato 80 reduziu a concentração livre de metil e propilparabenos para $22 \%$ e $4,5 \%$, respectivamente. POELMAN e colaboradores ${ }^{195}$, também, verificaram que a adição de $2 \%$ de polissorbato na solução de $0,1 \%$ de metilparabeno provoca a diminuição da concentração livre do mesmo para 38\%. Com o aumento da concentração do tensoativo para $10 \%$ a do agente antimicrobiano caiu para $10 \%$ da quantidade inicial.

O polissorbato 80 é o mais empregado, embora, segundo KOHN e colaboradores $^{123}$, o 20 seja mais efetivo na inativação de parabenos. 
A Farmacopéia Americana XXII 246 recomenda a adição de polissorbato 20 na concentração de $4 \%$, associada a $0,5 \%$ de lecitina, previamente misturados em caldo cseína-soja. Orientação semelhante configura na Farmacopéia Brasileira IV ${ }^{74}$, com a utilização de polissorbato 80 a $0,4 \%$ e $0,5 \%$ de lecitina no diluente.

A razão da inclusão da lecitina é a sua atividade neutralizante sobre compostos de amónio quaternário, clorhexidina e clorbutanol 177, 214, 254.

A associação de polissorbato e lecitina é consagrado tanto é que meios de cultura desidratados contendo esses compostos são comercializados sob denominação de caldo ou ágar letheen. PALMIERI 177 sugeriu, como diluente para avaliação de produtos de uso tópico, esse meio desidratado comercial adicionado de bissulfito de sódio. Segundo o autor, a lecitina e o polissorbato agem como tensoativos e emulsificantes e que, além de inativar conservantes, promovem o contato do microrganismo com a fase aquosa do meio de cultura. A função do bissulfito de sódio é neutralizar a ação dos conservantes tipo aldeído, como por exemplo, o glutaraldeído.

A inativação de outras substâncias com ação antimicrobiana é obtida com adição de neutralizantes específicos, como a $\beta$-lactamase para as penicilinas, o tiossulfato de sódio para os halogenados, tioglicolato de sódio ou cisteina para os mercuriais, etc. $214,215,254$.

Os recursos empregados para preparação da amostra, de modo a compatibilizá-los com a técnica de contagem, podem provocar danos aos microrganismos presentes 202.

A manutenção da amostra no fluido de diluição, com o tampão pH 7,2 por uma hora pode reduzir o número de microrganismos em até $80 \%$. Por outro lado, a adição de nutrientes pode promover a multiplicação quando em contato por períodos mais longos 228.

TURAKKA e colaboradores $\mathbf{2 5 0}$ relataram que o polissorbato 80 , 
adicionado no diluente na concentração de $5 \%$, ocasionou a diminuição do número de B. subtilis.

A Farmacopéia Americana XXII 246 permite até 1 hora entre a preparação da amosta e a semeadura em meio de cultura. BUOGO e RATTI ${ }^{37}$ e Van ABBÉ e colaboradores ${ }^{254}$ orientam que esse tempo não deve ultrapassar de 30 minutos. Em oposisão, a APHA 20,104 é mais rígida, recomendando que entre a diluição e a inoculação o tempo gasto seja preferencialmente dentro de 10 minutos e não ultrapasse 20.

¿Quando o método empregado é pela filtração da amostra, outros cuidados são envolvidos, pois o miristato de isopropila foi verificado ser tóxico para microrganismos. EVANS e colaboradores ${ }^{71}$ observaram que a permanência de bactérias, durante 10 minutos, nesse solvente esterilizado pelo calor, provocou perda de viabilidade de aproximadamente $90 \%$. TSUJl e colaboradores ${ }^{249}$, também, relataram que inóculos de $10^{2}$ de $P$. aeruginosa e $E$. coli foram destruidos à temperatura ambiente no mesmo tempo de contato. Segundo esses autores, o aquecimento acentua a toxicidade do miristato de isopropila. É considerando essa característica que os métodos oficiais recomendam a esterilização do solvente por filtração em membrana de 0,22 $\mu \mathrm{m}$ de porosidade 32, 68, 74, 246 . Entretanto, o solvente esterilizado por esse processo, também, é tóxico, pois apresenta o valor de " $\mathrm{D}$ " igual a 19 minutos, para $P$. aeruginosa ainda que esse dado seja 10 vezes menor que aquele, de quando submetido à autoclavação ${ }^{249}$. Essa toxicidade intrínseca para bactérias Gram-negativas pode fornecer resultados falsos, se a amostra não for dissolvida, filtrada e a membrana lavada rapidamente ${ }^{34}$.

A temperatura do meio de cultura a $45^{\circ} \mathrm{C}$, na técnica de semeadura em profundidade, também, foi citada por VANDERZANT e MATTHYS ${ }^{255}$ como causa de redução de viabilidade de microrganismos psicrofílicos. 


\subsubsection{Técnicas de contagem de microrganismos viáveis}

Os métodos de determinação do número de microrganismos viáveis, constantes em farmacopéias, referem-se à contagem em placas por semeadura em profundidade, à filtração por membrana e ao ensaio estimativo dos tubos múltiplos ou da diluição, pelo número mais provável (NMP) 32, 60, 68, 74, 246.

A escolha de um deles deve basear-se nas características do produto a ser examinado, quanto à hidrossolubilidade ou não, à natureza dos componentes no que diz respeito à atividade antimicrobiana e ao grau de contaminação estimado ${ }^{47}$. O método deve ser de simples execução, porém capaz de fornecer resultados quantitativos exatos e precisos ${ }^{36}$.

A Farmacopéia Americana XXII ${ }^{246}$, por exemplo, cita que para produtos hidrossolúveis, com componentes antimicrobianos, o método de filtração pode ser empregado. Entretanto, não descreve a metodologia no capítulo correspondente ao teste de limite microbiano, orientando para se reportar àquela do teste de esterilidade. Para amostras suficientemente solúveis ou aquelas cuja dispersão seja translúcida ao ponto de permitir a visualização de colônias, esse compêndio recomenda a utilização da técnica de ágar fundido, em placas, reservando aquela em meio líquido para os casos em que a contagem em meio sólido não é aplicável.

A Farmacopéia Britânica ${ }^{32}$ e a Alemã ${ }^{60}$ descrevem os 3 métodos, porém não especifica a natureza dos produtos para os quais cada um deva ser adotado. Por outro lado, na Farmacopéia Brasileira IV $\mathbf{7 4}$, as técnicas são detalhadamente descritas para cada grupo de produtos com determinada característica física.

BUHLMANN ${ }^{36}$, em 1968, sugeriu a divisão das amostras em 2 classes para fins de avaliação da qualidade microbiológica. Uma abrangendo produtos aquosos ou solúveis em água, testadas por filtração em membrana e outra dos 
insolúveis, por contagem em placas.

A Federação Farmacêutica Internacional (FIP) 47 adotou as sugestões desse autor e estabeleceu, para amostras que podem ser filtradas, 0 método de filtração por membrana como o de escolha. Recomenda a utilização das técnicas de contagem em ágar e em tubos múltiplos para aquelas que não atendem às exigências da filtração, com ênfase particular para a de número mais provável no caso de amostras com baixa carga contaminante.

A orientação da Organização Mundial da Saúde 263 quanto ao critério para escolha do método é a mesma. Recomenda a contagem em placas para produtos na forma de sistema disperso, com carga microbiana acima de 100 organismos /g ( $\mathrm{mL}$ ) e o método do número mais provável para aqueles com carga menor.

Tendo em vista algumas vantagens e desvantagens inerentes a cada um dos métodos, algumas vezes são efetuados ensaios prévios. Nesse sentido, KALUNGS e colaboradores 118 utilizaram 2 estágios para avaliação da qualidade microbiana de medicamentos não estéreis comercializados na Suécia. Inicialmente, as amostras foram submetidas à triagem, em meios líquidos. Apenas aquelas que apresentaram crescimento foram reanalisadas efetuando-se determinações quantitativas pelo método de contagem em placas.

O FDA, segundo PALMIERI 177 , também, utiliza o teste prévio, inoculando-se $1 \mathrm{~g}(\mathrm{~mL})$ em meios líquidos, antes da determinação quantitativa.

O método de contagem em placas por semeadura em profundidade é considerado preciso, rápido e de fácil execução. No entanto, como todo método biológico está sujeito a falhas, podendo ocorrer erros de até $100 \%{ }^{215}$

As células microbianas frequentemente ocorrem como aglomerado nas amostras. A adição do diluente na tomada de ensaio e subsequente agitação tem a finalidade de distribuir homogeneamente as células contaminantes, porém esses 
processos podem não separá-las completamente. A agitação inicial com misturador mecânico pode ser mais eficiente, embora não assegure a distribuição dos microrganismos como células isoladas. Consequentemente, cada colônia no meio pode ser originária de uma ou de um aglomerado de células. Outra fonte de erros pode ser a incapacidade de alguns microrganismos formarem colônias em meio sólido ${ }^{38}$.

Para líquidos viscosos pode não ocorrer a completa homogeneização da amostra com o meio de cultura, resultando em colônias aglomeradas, o que será outro fator de erro ${ }^{71}$.

A desvantagem desse método, enfatizada por alguns autores ${ }^{36}$, 177, 213, é a possibilidade dos contaminantes serem parcialmente danificados em consequência da temperatura do meio de cultura de aproximadamente $45^{\circ} \mathrm{C}$, e com isso sendo incapazes de crescimento durante a incubação. Esse propblema foi comprovado para bactérias psicrófilas ${ }^{255}$.

ROMOND 213 considera como vantagens do método de "pourplate" sobre a contagem por semeadura em superfície a possibilidade maior de deteç̧ão de bactérias anaeróbicas facultativas, além de deparar com menos problemas quando da presença de bactérias invasivas. Apesar disso, a dificuldade na identificação de colônias é apontada como desvantagem.

A aplicação do método de contagem em placas por semadura em profundidade é limitante para amostras contendo carga contaminante abaixo de determinado número. BREED e DOTTERRER ${ }^{28}$, em 1916, relataram que para contagem de número de colónias numa placa, a faixa de menor erro era de 30 a 300 colônias. Os métodos de contagem de microrganismos em medicamentos e cosméticos propostos, seguiram essa orientação $47,213,254$.

Mais recentemente, TOMASIEWICZ e colaboradores ${ }^{247}$ indicaram ser mais adequada a faixa de 25 a 250 colônias. Esses valores foram adotados pelo American Public Health Association (APHA), nos métodos padrões para análise de 
alimentos, edição de $1984{ }^{38}$. A Farmacopéia Americana de 1990 (USP XXII) ${ }^{246}$, porém, mantém a primeira orientação.

Segundo RUSSEL ${ }^{215}$, o número mínimo de 30 colônias por placa, considerado adequado estatísticamente, restringe a aplicação desse método para suspensões com carga menor que 60 organismos/ g $(\mathrm{mL})$. Isso, em decorréncia da preparação da amostra na diluição 1:10 e necessidade da inoculação de pelo menos 5 $\mathrm{mL}$ dessa diluição, o que acarreta como inconveniência a redução da firmeza do gel, quando se utilizam placas de Petri com $10 \mathrm{~cm}$ de diâmetro.

As últimas edições das Farmacopéias Brasileira ${ }^{74}$, Britânica ${ }^{32} \mathrm{e}$ Alemã 60 não fazem menção ao limite inferior, porém recomendam que a contagem deve ser efetuada nas placas com menos de 300 colónias.

BUSTA e colaboradores ${ }^{38}$ orientam que quando as colônias em número maior que 100 não apresentam separação adequada entre as mesmas, podese efetuar o cálculo a partir dos dados das placas com 10 a 100 colónias. Para avaliação do número de bolores e leveduras, que se enquadra na situação acima descrita, o método da FIP ${ }^{47}$ recomenda que a contagem seja efetuada nas placas com 50 a 100 colônias. As Farmacopéias Britânica ${ }^{32}$ e a Brasileira ${ }^{74}$ também sugerem como limite superior 100 colônias de fungos por placa.

A presença de bactérias com características de crescimento invasivo, espalhando-se rapidamente na superfície do gel, dificulta a contagem das colónias. Nesses casos, a orientação do procedimento a ser adotado será a invalidação da placa quando mais da metade da área da placa estiver coberta com o crescimento ${ }^{254}$. Nos casos em que a proporção ocupada for menor, a contagem das colônias poderá ser efetuada em áreas livres desses microrganismos. Entretanto, quando não for possível evitar a contagem, BUSTA e colaboradores ${ }^{38}$ sugerem critérios para diminuir o erro. Segundo os mesmos autores, colônias em forma de cadeia parecem ser provenientes da desagregação de aglomerados de bactérias em função da homogeneização da amostra com o meio de cultura, inerente à técnica de 
semeadura em profundidade. Apesar desse parecer, segundo os autores, a cadeia deve ser contada como uma colónia, no caso de presença de apenas uma. Porém, a orientação difere dessa quando uma ou mais cadeias prsentes parecem ser originadas de fontes separadas. Nesse caso, os autores recomendam a contagem de cada cadeia que parece ser proveniente de uma fonte, como uma colónia.

BUSTA e colaboradores ${ }^{38}$, comentam, ainda, sobre as colônias que se espalham na interface do meio de cultura e a parede da placa, seja no fundo ou lateral, ou sobre a superfície do ágar, como sendo decorrentes do acúmulo de umidade naqueles pontos. Quando a amostra é uniformemente homogeneizada com o meio de cultura, raramente os microrganismos se desenvolvem dessa forma. Esses autores orientam que qualquer laboratório com $5 \%$ de placas com mais de $1 / 4$ de área coberta com essas colónias, deve adotar medidas para eliminação desse problema. ROMOND 213 sugere adição de fina camada de ágar sobre a camada do meio semeado, como recurso para sanar o problema.

Modificações da tradicional técnica de semeadura em profundidade foram propostos para diminuir as interferências responsáveis pelo erro analítico 47,121. A FIP 47 sugere a análise envolvendo 2 camadas: a primeira, basal, consiste somente de meio de cultura; a amostra, préviamente misturada com o meio de cultura fundido, é depositada sobre o meio basal solidificado. $\mathrm{KOCH}{ }^{121}$ propõe, ainda, a adição de uma terceira camada de meio de cultura sobre o semeado.

O método de contagem em placas pela semeadura em superfície não consta dos compêndios oficiais, porém, foi utilizado em levantamentos de avaliação da qualidade microbiológica de medicamentos e cosméticos $37,159,166$.

Essa técnica foi recomendada por ROMOND ${ }^{213}$ e pelo FDA 177 para análise de cosméticos e preparações para uso tópico. A justificativa pela preferência da semeadura em superfície sobre o método de "pour-plate" é para evitar efeitos prejudiciais provocado pelo calor do meio fundido, pois pode ser até fatal para microrganismos debilitados 180,203,255. Em estudo comparativo, as contagens 
efetuadas por esse método forneceram resultados com carga contaminante maior que aquele de semeadura em profundidade, para algumas amostras 36, 44, 197, 203.

A transparência do meio não é fator essencial para a eficiência desse método, podendo ser empregado para amostras que provocam opalescência do gel, como as suspensões. Outro fator positivo do método é a facilidade de observação da morfologia das colônias, posssibilitando ao analista distinguir mais facilmente a presença de diferentes tipos de contaminantes ${ }^{38}$.

Nessa técnica, a capacidade de absorção do líquido pelo gel para se obter colônias isoladas, limita a quantidade de amostra a ser semeada. Volumes de 0,1 a $0,5 \mathrm{~mL}$ são recomendados, ainda que alíquotas de $1,0 \mathrm{~mL}$ tenham sido empregadas $38,166$.

Para aplicação dessa técnica, RUSSEL 215 considera $15 / 9(\mathrm{~mL}) 0$ número de microrganismos limitante na amostra original, uma vez que não é praticavel semeadura de volume maior que $2,0 \mathrm{~mL}$. Por outro lado, amostras com número elevado de microrganismos podem ser submetidos a diluição prévia, para se ter número de colônias menor que 150, número considerado adequado para contagem por essa técnica.

O método de filtração em membrana foi recomendado como método mais adequado para avaliação de amostras filtráveis. Entretanto, como outros métodos, esse também apresenta vantagens e desvantagens 46, 76.

BARZAGHI e colaboradores ${ }^{18}$, no estudo de reprodutibilidade de dados efetuados em diferentes laboratórios, não obtiveram resultados equivalentes. Segundo os autores, a técnica é de fácil execução, aparentemente, pois vários fatores como diferença de fluxo das substâncias nutrientes através da membrana, a falta de uniformidade da membrana quanto à umectação pelo meio de cultura, falhas na execução do teste, etc, podem resultar em erros.

A aplicação desse método em amostras onde não se conhece a 
magnitude da carga microbiana presente, exige filtração de diferentes alíquotas. LUHDORF e TYBRING ${ }^{142}$ testaram 421 amostras de solução de uso oral, empregando teste preliminar. Para isso, filtrando $1,0 \mathrm{~mL}$ da amostra, esse dado permitiria determinar a diluição necessária para se ter número adequado de colônias para contagem. RUSSEL 215 considera como limite máximo 100 colônias e a FIP 47 200. Segundo BUHLMANN ${ }^{36}$, a filtração de 1,0 e 10,0 mL da amostra sem diluição tem-se mostrado satisfatório para o controle de medicamentos.

HIRSCH e colaboradores 100 utilizaram filtros adaptados em seringas, uma vez que são sitemas mais económicos e rápidos que as unidades de filtração convencionais. RODRIGUES e KROL ${ }^{214}$ propuseram uma variação do método de filtração por membrana baseada na contagem direta de células, visando diminuir o tempo de incubação. A técnica empregada por esses autores consiste na deposição da membrana em solução de alaranjado de acridina, após incubação no meio de cultura. A contagem de microcolônias é efetuada empregando-se microscópio de epifluorescência. Segundo os autores, o tempo de incubação para o desenvolvimento das microcolónias foi de 3 a 6 horas, sendo o método aplicável para amostras com carga acima de $10^{3}$ bactérias $/ \mathrm{g}(\mathrm{mL})$.

O método da diluição ou número mais provável (NMP) é estimativo da densidade de microrganismos viáveis na amostra. O NMP baseia-se na probabilidade estatística e os resultados estão diretamente relacionados a frequência de uma série de resultados positivos ${ }^{170,171 .}$

O NMP pode ser empregado para uma única ou várias diluições. Segundo HALVORSON e ZJEGLER ${ }^{96}$, no caso de uma única diluição a precisão depende não somente do número de tubos inoculados mas também da população microbiana. Teoricamente, pelo desenvolvimento da equação da probabilidade, o máximo de precisão é obtido com população entre 1,2 a 1,5 organismos/mL. Considerando-se que o número de microrganismos é desconhecido, não é possível determinar a real precisão da determinação. Quando se utilizam várias diluições, a 
precisão é independente do número de microrganismos e dependente somente do número de tubos de cada diluição ${ }^{97}$.

Esse método é considerado pouco preciso quando comparado ao método de contagem em placas por semeadura em profundidade, pois cada tubo corresponde a pequena fração da superfície da placa de Petri ${ }^{121}$. MAC CARTHY e colaboradores 151 verificaram que a precisão do método de "pour-plate", com 10 réplicas, foi 3 vezes maior que o NMP.

Os métodos oficiais para a análise de medicamentos e alimentos recomendam réplicas de 3 ou 5 tubos de cada diluição. Porém, segundo $\mathrm{KOCH}{ }^{122}$, o resultado obtido com esses números de réplicas é pouco preciso e considera adequado quando for com 10 tubos de cada diluição, como foi proposto por HALVORSON e ZIEGLER ${ }^{96,97}$. O autor sugere o cálculo do NMP para cada resultado obtido através de programa aplicável a calculadora programável, pois, das 1000 possíveis combinações, nas tabelas constam apenas 210 .

BUOGO e RATTI ${ }^{37}$ analisaram 32 xaropes e 60 medicamentos sólidos como comprimidos e drágeas pelo método do NMP e pela contagem em placas com semeadura em superfície. Os resultados obtidos foram equivalentes para bactérias. Entretanto, a contagem do número de bolores foi maior pelo método de placas. Segundo os autores, a diferença pode ser decorrente da auto contaminação por esporos que são liberados na mesma placa, a partir de colônias que crescem e esporulam rapidamente. Frente aos resultados obtidos, os autores consideram que a qualidade microbiana de uma produção normal de medicamentos pode ser controlada através do NMP e pela pesquisa de algum microrganismo facilmente identificável como E. coli.

EVANS e colaboradores ${ }^{71}$ relatam que 3 loções do tipo O/A deliberadamente contaminadas, foram analisadas por vários laboratórios pelo método de semeadura em profundidade ou pelo método de diluição. Os resultados obtidos foram igualmente satisfatórios, apesar da variação das técnicas, meios e diluentes. 
Segundo ROMOND ${ }^{213}$, apesar da imprecisão, esse método apresenta vantagens sobre os outros, que justifica a sua utilização. Segundo o mesmo, - meio líquido é favorável para recuperação de microrganismos debilitados por condições agressivas da amostra; a possibilidade de testar quantidade maior de amostra, sem diluição do meio de cultura, desde que se empregue concentração dupla de nutrientes, e aplicabilidade para amostras de qualquer natureza física.

Quando da aplicação do método do NMP para amostras que não permitem a visualização da turvação proveniente do crescimento microbiano, é necessário o auxilio de recursos como sub-cultura, adição de corantes de oxi-redução como resazurina, azul de metileno e cloreto de trifeniltetrazólio $32,47,74,170,246$. A subcultura pode ser executada no meio líquido ou sólido 32, 47, 74, 246.

A observação microscópica é outro recurso que pode ser empregado, para essa finalidade, porém, alta carga inicial de microrganismos não viáveis podem falsear o resultado ${ }^{170}$.

Os microrganismos possuem grande divergência na temperatura ótima de crescimento. Consequentemente, a temperatura de incubação para detecção deveria ser aquela ideal para o crescimento dos microrganismos presentes. $\mathrm{Na}$ determinação inespecífica a temperatura é dirigida para microrganismos potencialmente presentes ${ }^{38}$.

Em medicamentos e cosméticos, geralmente as bactérias presentes são mesófilas. Esses contaminantes desenvolvem-se a temperatura de 37 a $40^{\circ} \mathrm{C}$, porém, são inibidos a $20^{\circ} \mathrm{C}$. Algumas bactérias crescem bem em larga faixa de temperatura, enquanto outras são mais exigentes ${ }^{254}$. Muitos microrganismos provenientes de água não se desenvolvem em temperatura acima de $30^{\circ} \mathrm{C}$, enquanto para alguns, a incubação a $25^{\circ} \mathrm{C}$ é limitante ${ }^{215}$.

Antes de 1950 a temperatura de incubação estabelecida para a maioria dos testes de esterilidade era de $37^{\circ} \mathrm{C}$ para bactérias e $20-25^{\circ} \mathrm{C}$ para bolores e 
leveduras. Posteriormente e gradativamente nos métodos de várias farmacopéias, a temperatura foi alterada para $32-35^{\circ} \mathrm{C}$ em função das bactérias comuns do ar representarem maior fonte potencial de contaminação de produtos farmacêuticos em vez dos patogênicos. A ocorrência de infecção em pacientes que receberam plasma contaminado $\operatorname{com} P$. aeruginosa direcionou a temperatura de incubação do teste para $30-32^{\circ} \mathrm{C}$, uma vez que esse agente foi inviabilizado a $35^{\circ} \mathrm{C}$. Entretanto, em 1970 , a Farmacopéia Americana XVIII retornou à orientação para faixa de $30-35^{\circ} \mathrm{C}{ }^{216}$.

Além da temperatura, o conhecimento da relação com o tempo de incubação é importante para interpretação de resultados, principalmente quando se utiliza meios seletivos. Métodos estabelecidos para alimentos são rígidos nesse aspecto. Pode-se observar tal preocupação quando, nos métodos da AOAC ${ }^{5}$ para contagem de bactérias em placas, especificam tempo de $48 \pm 3$ horas para o leite chegando a rigidez de 4 dias \pm 3 horas para outros alimentos.

Nos trabalhos de levantamento da qualidade microbiana de medicamentos não estéreis realizados nas décadas de 60 e 70, diferentes temperaturas e tempos de incubação foram empregados, uma vez que não haviam métodos padronizados. Temperaturas de 22 a $37^{\circ} \mathrm{C}$ foram utilizados para contagem de bactérias e 20 a $25^{\circ} \mathrm{C}$ para bolores e leveduras ${ }^{80,} 84,100,159,166,183,203,223,252,259$.

KALLINGS e colaboradores 118 empregaram a temperatura de $37^{\circ} \mathrm{C}$ para triagem qualitativa das amostras quanto à presença de contaminantes em meio líquido. Para a determinação quantitativa, houve a preocupação desses autores na deteç̧ão de bactérias mesófilas e também das psicrófilas, incubando-se as placas a $35^{\circ} \mathrm{C}$ durante 24 horas e a $22^{\circ} \mathrm{C}$ por 48 horas.

Nos levantamentos efetuados pelos Laboratórios da National Health Pharmacetical Service da Dinamarca 80,84,142,183,203,223,252, visando a determinação da carga microbiana viável em medicamentos e matérias- primas não estéreis pela técnica de tubos múltiplos e também em contagens em meio sólido, não houve padronização quanto à temperatura e tempo de incubação. Para a técnica de 
diluição a temperatura foi $d e 37^{\circ} \mathrm{C}$, independentemente da forma farmacêutica, porém, o tempo de incubação variou de 3 a 5 dias. Quando foi empregado o meio sólido as condições foram differentes para cada forma farmacêutica. Para análise de comprimidos e medicamentos de uso tópico a temperatura foi de 35 a $37^{\circ} \mathrm{C}$ durante 3 dias; para matérias-primas, 32 a $34^{\circ} \mathrm{C}$ por 3 a 5 dias e para líquidos, de 30 a $32^{\circ} \mathrm{C}$ durante 3 dias. A contagem de bolores e leveduras foi a $20-25^{\circ} \mathrm{C}$ por 7 dias.

Segundo BUHLMANN ${ }^{36}$, a incubação a $30^{\circ} \mathrm{C}$ possibilita detecção de bactérias mesófilas e psicrófilas e também de bolores e leveduras, empregando-se meio de caseina-soja $\theta$ Sabouraud, respectivamente. ROMOND 213 também sugere a temperatura de $30^{\circ} \mathrm{C}$ para bactérias mesófilas, enquanto que BUOGO e RATTI ${ }^{37}$, $35^{\circ} \mathrm{C}$ durante 48 horas.

Os métodos propostos para avaliação de cosméticos, também, não são padronizados quanto às condições de incubação. Faixas de temperaturas de $28-32^{\circ} \mathrm{C}$ e $35^{\circ} \mathrm{C}$ para bactérias e de $22-25^{\circ} \mathrm{C}$ e $26-30^{\circ} \mathrm{C}$ para fungos, foram sugeridas $81,254$.

Nos códigos oficiais em vigor 32, 60, 74, 246 a temperatura de incubação é padronizada para $30-35^{\circ} \mathrm{C}$ para bactérias e $20-25^{\circ} \mathrm{C}$ para bolores e leveduras, porém, o tempo difere em cada farmacopéia. Para as bactérias, a Americana 246 estabelece de $24-48$ horas, a Britânica ${ }^{32}$ de 2 a 5 dias, a Brasileira ${ }^{74}$ de 4 dias e a Alemã ${ }^{60}$ de 5 dias. Para bolores e leveduras, respectivamente de 5 a 7,2 a 5,7 e 5 dias.

Além das condições já comentadas, a característica nutricional do meio de cultura é outro aspecto importante que influi na precisão dos resultados.

Em estudos de contaminação microbiana em medicamentos, um único meio de cultura foi empregado para contagens de bactérias e fungos, diferindo apenas na temperatura de incubação $118,158,166$.

Segundo SCOTT ${ }^{216}$, considerando-se que nenhum meio promove 
o crescimento de todas as bactérias, bolores e leveduras, mais de um deveria ser utilizado para contagem de microrganismos contaminantes. BRUSCH ${ }^{34}$, pela mesma justificativa, recomenda a contagem em 2 meios de cutura para análise de medicamentos.

Os meios de cultura, empregados ou recomendados, para determinação do número de bactérias em medicamentos e cosméticos são: ágar sangue ${ }^{159,259}$ ágar peptona de carne ${ }^{118}$, ágar "plate count ${ }^{1258}$ (ágar triptona glicose e extrato de levedura) ${ }^{254}$, ágar nutriente ${ }^{37}$, ágar e caldo caseína-soja ${ }^{36,166}$ e caldo tioglicolato ${ }^{37}$. Para determinação de bolores e leveduras: ágar e caldo Sabourauddextrose 36, 37, 47, 166 e ágar extrato de malte 177, 254. O meio de caseína-soja adicionado de polissorbato, lecitina e bissulfito de sódio foi empregado pelo FDA 177 para análise de cosméticos e medicamentos de uso tópico.

Métodos oficiais em vigor 32, 60, 68, 74, 246 indicam o meio de caseína-soja para bactérias e o Sabouraud-dextrose para bolores e leveduras. Para aumentar a seletividade do meio de Sabouraud-dextrose as Farmacopéias Britânica, Européia e Alemã recomendam adição de antibióticos para inibir o crescimento de bactérias. Benzilpenicilina sódica e tetraciclina na concentração de $0,1 \mathrm{~g}$ por litro ou 0,005\% de cloranfenicol são os antibióticos sugeridos ${ }^{32,47,60,68}$.

Para cosméticos, o FDA ${ }^{\mathbf{8 1 , 1 7 7}}$ sugere a adição de 0,004\% de clortetraciclina no meio de Sabouraud-dextrose ou ágar batata dextrose acidificado.

O método da FIP $\mathbf{4 7}$ recomenda, além da adição de antibióticos, o exame microscópico para confirmação de leveduras em relação a bactérias resistentes.

VAN ABBÉ ${ }^{254}$ recomenda a adição de cicloheximida a 0,001\% no meio de ágar "plate count" para inibição de leveduras.

$\mathrm{Na}$ Inglaterra os levantamentos efetuados em medicamentos pelo Laboratório de Serviço de Saúde Publica ${ }^{159}$ e em matérias-primas por WESTWOOD 259 empregaram o mesmo meio para contagem de bactérias e fungos. A diferenciação 
foi obtida através da temperatura de incubação de $37^{\circ} \mathrm{C}$ durante 48 horas para as primeiras e $22-25^{\circ} \mathrm{C}$ por 7 dias para bolores $\theta$ leveduras.

Alguns códigos oficiais recomendam a validação do teste através da verificação da capacidade promotora de crescimento de meios de cultura 32,60,74 . Consiste da inoculação de S. aureus, B. subtilis, E. coli e C. albicans, nas condições especificadas para o teste das amostras. Nesse particular, SCOTT 216 contesta a utilização de microrganismos padrões, sugerindo o emprego de microrganismos isolados do proprio produto pelo fato de permitir avaliação mais real.

\subsubsection{Métodos analíticos alternativos}

Sabe-se que os métodos microbiológicos tradicionalmente empregados para determinação da carga contaminante em medicamentos e cosméticos são, também, trabalhosos e requerem longo tempo para obtenção de resultados. Isso em função do período de incubação, geralmente de 24 horas a 7 dias, necessário para visualização do crescimento microbiano $57,109,138$.

Como foi relatado anteriormente, os compêndios oficiais apresentam como métodos para avaliação de medicamentos não estéreis, apenas os de contagem em placa por semeadura em profundidade, a técnica de filtração em membrana e a de tubos múltiplos. Entretanto, a Farmacopéia Americana (USP XXII) 246 de 1990 cita que métodos automatizados podem ser empregados em substituição aos descritos, desde que validados como sendo equivalentes ou melhores.

Vários métodos alternativos foram desenvolvidos para aplicação em controle de qualidade em indústrias, principalmente de alimentos, visando a redução de trabalho ou eliminação ou diminuição do tempo de incubação requerido pelas técnicas tradicionais $\mathbf{5 7 , 1 0 2 , 1 3 8 .}$ 


\subsubsection{Métodos por automatização de técnicas tradicionais}

Dentre várias alternativas aquelas que visam a redução de trabalho e material baseiam-se na automatização de técnicas tradicionais. Uma delas, aquela proposta pela APHA ${ }^{102}$, visa eliminar a etapa de diluição das amostras, quando o ensaio é pelo método de semeadura em profundidade. Como nesse caso o número de colônias por placa deve situar-se entre 30 a 300 ou 25 a 250, esse recurso, descrito para análise de laticínios, introduziu a inoculação de volumes reduzidos, da ordem de 0,001 $\mathrm{mL}$, semeados com alça devidamente calibrada. A técnica, apesar de simples, deve ser devidamente padronizada para evitar erros, principalmente decorrentes do reduzido volume de inoculação. O volume empregado limita a aplicação desse método a amostras com carga microbiana na faixa de $10^{4}$ a $10^{5}$. Segundo WRIGHT e colaboradores $^{264}$, a utilização dessa técnica é viável desde que a carga contaminante da amostra não exceda a $2 \times 10^{5} \mathrm{UFC} / \mathrm{mL}$

O método da gota também visa a eliminação das diluições. Consiste na inoculação da amostra através da deposição de determinado número de gotas, de volume previamente conhecido, a partir de pipetas especialmente calibradas, na superfície do gel. As gotas espalham-se naturalmente em áreas de 1,5 a 3,0 cm de diâmetro e as placas são incubadas após a absorção do líquido pelo meio de cultura ${ }^{38}$ Em função do reduzido volume, o método não é recomendado para se testar amostras com menos de $3 \times 10^{3} \mathrm{UFC} / \mathrm{g}(\mathrm{mL})$. Esse método é sugerido por BAIRD ${ }^{12}$ para triagem de amostras quando há suspeitas de alta carga contaminante.

Outra técnica proposta para obter-se número aproximado de microrganismos consiste em passar a superfície do meio de cultura solidificado, contido em lâmina com cavidade, no líquido a ser testado. O nível mínimo de detecção é de $10^{3}$ $\mathrm{UFC} / \mathrm{mL}^{215}$.

CARVALHAL e colaboradores 42 desenvolveram o método combinado do NMP com a técnica de gotas em superfície. Gotas de $5 \mu \mathrm{L}$ de cada 
diluição da amostra são depositados em cada setor delimitado por um "template". Cada espaço individual corresponde a1 tubo do método convencional. Segundo os autores, uma placa de Petri de $140 \mathrm{~mm}$ pode acomodar 14 diluições. A leitura dos resultados baseia-se na presença ou ausência de crescimento e a obtenção do número mais provável é calculado segundo mesmo princípio do método tradicional. Os autores verificaram correlação entre o método da gota e a contagem em superfície, utilizandose para o método alternativo 3 diluições decimais sucessivas com réplicas de 5 para cada diluição.

Baseando-se no mesmo propósito, de eliminação de diluição da amostra, foi desenvolvido o método de inoculação automatizada para contagem de microrganismos $5,64,90,91,102,138,264$. Nessa técnica, um volume conhecido de amostra é semeado em forma de espiral de Arquimedis sobre a superfície do meio de cultura solidificado. A quantidade de amostra decresce à medida que o espiral move-se do centro para a parede da placa, e após incubação as colónias aparecem ao longo da linha do espiral.

A determinação do número de microrganismos na amostra é efetuada com auxilio de contador que divide a placa em áreas delimitadas por linhas circulares e radiais. A contagem das colônias é efetuada nas áreas onde o número é mais adequado. A sensibilidade desse método limita a sua aplicação a amostras com cargas de $5 \times 10^{2}$ a $5 \times 10^{5}$ UFC/mL 5,102,138. Sua aplicabilidade, em função da natureza física da amostra, restringe-se à líquidos na forma de solução ou aquelas facilmente homogeneizadas e que resultem em suspensões não muito viscosas.

Amostras com partículas ou líquidos viscosos podem ser analisados por esse método, submetendo-se à filtração prévia ou à diluição. Entretanto, essas operações redundam em mais trabalho, com pouca vantagem sobre o método de contagem em placas $57,{ }^{109}$. Esse método é recomendado pelo AOAC 5 para contagem de microrganismos em alimentos e cosméticos. Segundo um estudo colaborativo efetuado em leite e alimentos, o método mostrou ser equivalente à 
contagem padrão em placas ${ }^{91,185}$

JARVIS e EASTER 109, ao efetuar pesquisa, através de questionário, junto aos laboratórios de microbiologia de industrias farmacêuticas, de cosméticos, de bebidas e de alimentos, concluiu, que cerca de $10 \%$ utiliza esse método em substituição à tradicional contagem em placas.

\subsubsection{Métodos de contagem direta}

Entre os métodos alternativos desenvolvidos, visando redução ou eliminação do período de incubação, alguns permitem a obtenção de resultados em tempo menor que 12 horas e outros, até em menos de 1 hora $57,102,138$.

A contagem eletrônica direta das células é uma técriica rápida e quantitativa. O método consiste na passagem da amostra diluida em solução de eletrólitos, em fluxo através de pequeno orifício. Os microrganismos presentes são detectados pelo aumento da resistência elétrica, quando da sua passagem, uma vez que a condutividade do meio é menor 121,138. Essa técnica é empregada rotineiramente em hematologia clinica. No entanto, para aplicação em microbiologia possui limitações. Bactérias muito pequenas são dificilmente detectadas e a grande desvantagem é a contagem total dos microrganismos, tanto viáveis como os não viáveis ${ }^{121}$.

A natureza da amostra pode ser fator limitante para sua aplicação, pois o método é compatível com líquidos não viscosos e isento de partículas ${ }^{109}$.

LEECH 138 testou esse método para xaropes, contaminados com Pseudomonas sp, obtendo resultados satisfatórios.

PINDER e colaboradores 192 introduziram modificação nesse método, empregando 2 parâmetros de detecção, a saber: tamanho de partículas e conteúdo em ácidos nucleicos, após reação com brometo de etídio. Segundo os autores, a técnica apresenta boa correlação com o método de contagem em placas 
para cargas de $10^{2}$ a $10^{7}$ microrganismos $/ \mathrm{mL} \theta$ a resposta pode ser obtida em poucos minutos.

Entre os métodos alternativos para detecção de microrganismos, um dos mais difundidos para monitoração microbiológica em indústrias farmacêuticas, de alimentos e bebidas e também na avaliação da qualidade de água, consiste na contagem celular direta após filtração e coloração, utilizando-se de microscópio de epifluorescência 58, 59, 109, 138, 211, 212.

A filtração associada à epifluorescência é uma técnica simples e rápida, pois permite a obtenção de resultados em menos de 1 hora $\mathbf{5 7 , 1 3 8}$. Outra vantagem sobre os outros métodos é a possibilidade de quantificar diretamente 0 número de microrganismos viáveis ${ }^{138}$.

O alaranjado de acridina é o composto fluorogênico mais empregado nesse método, para visualização das células $26,58,59,138,211$. A reação desse corante na ligação com os ácidos nucleicos da célula intensifica a fluorescência, sendo que células viáveis adquirem fluorescência alaranjada, decorrente da mistura de amarelo esverdeada do corante ligado ao DNA e de vermelha, ao RNA 94, 138, 145.

A relação entre a viabilidade e a cor da fluorescência foi demonstrada por MC KINNON e MANSELL ${ }^{153}$. No entanto, segundo DENYER e WARD ${ }^{58}$, o número de bactérias foi mais próximo daquele obtido através de contagem em placas quando foi considerada a soma das células com fluorescência esverdeada e vermelho-alaranjada.

De acordo com RODRIGUES e KROLL 211, a coloração com alaranjado de acridina não foi satisfatória para contagem de leveduras, considerandose a dificuldade de diferenciação entre as células viáveis e não viáveis. A modificação proposta pelos autores para melhorar a eficiência do método foi a coloração conjunta desse corante e o verde Janus. Essa técnica forneceu resultados mais próximos aos obtidos por contagem em placas, quando foram testadas suspensões de culturas 
puras em diluentes. Entretanto, quando foi aplicado à análise de bebidas, a diferenciação foi pouco confiável.

O alaranjado de acridina é o composto mais empregado nesse método, embora outras substâncias tenham sido uttilizadas para visualização das células ${ }^{180,267}$. O diacetato de fluoresceína foi sugerido por PATON e JONES ${ }^{180}$ para contagem de bactérias e leveduras viáveis. ZIMMERMANN e colaboradores 267 empregaram o cloreto de 2-(p-iodofenil)-3-(p-nitrofenil)5-feniltetrazólio para contagem de bactérias aquáticas.

A contagem direta de microrganismos corados em suspensão, utilizando câmaras de contagem como Petroff-Hausser, foi empregada para culturas puras $41,49,94,184$. Sua aplicação em amostras só é possível quando as mesmas estão com alta carga microbiana, da ordem de $10^{8} / \mathrm{mL}$, o que não é a condição geralmente observada em produtos farmacêuticos e cosméticos, razão pela qual emprega-se a contagem em membrana após filtração de alíquotas compativeis com o nível estimado de contaminação $\mathbf{5 7 , 9 4}$.

A eficiência da técnica de contagem direta após filtração está relacionada às características da membrana. Para que os resultados obtidos sejam precisos e exatos a membrana deve propiciar a retenção de todos os microrganismos presentes na amostra, que por sua vez, devem ser visíveis sobre a superfície do filtro. Ao lado disso, deve permitir alto contraste entre a bactéria e o fundo, após coloração 26,101

O filtro de policarbonato possue características que atendem melhor à essas exigências que o de celulose, pois possuem poros mais uniformes além da superfície plana, que permite a retenção de todas as bactérias presentes na amostra sobre a superfície da membrana $26,58,59,101,136,176$. Tal fato foi comprovado por HOBBIE e colaboradores ${ }^{101}$ e BOWDEN ${ }^{26}$, pois pelas contagens comparativas efetuadas empregando os 2 tipos de filtros, o policarbonato mostrou ser superior, obtendo-se números maiores. 
Em alguns métodos analíticos visando a filtração de microrganismos há recomendação para uso de membrana com porosidade de 0,45 $\mu \mathrm{m}$ 74,245. Entretanto, no estudo de HOBBIE e colaboradores ${ }^{101}$, a contagem de bactérias em amostras de água, usando filtro de policarbonato de $0,2 \mu \mathrm{m}$, acusou o dobro do número detectado pela membrana de celulose de $0,45 \mu \mathrm{m}$.

A grande vantagem do método de contagem direta após filtração em relação a outros processos alternativos é a possibilidade de aplicação em amostras com baixa carga contaminante, uma vez que a sensibilidade é dependente do volume que pode ser filtrado ${ }^{58}$.

Segundo PETIPHER e RODRIGUES ${ }^{188}$, a sensibilidade de detecção microbiana para amostras de leite foi de $10^{3}-10^{4}$ microrganismos $/ \mathrm{mL}$. Por outro lado, DENYER e WARD ${ }^{58}$ conseguiram detectar até 25 bactérias por mililitro em fluidos intravenosos, filtrando-se volume de $500 \mathrm{~mL}$ Sensibilidade maior foi obtida por DENYER e LYNN ${ }^{59}$ utilizando pré-enriquecimento, através de incubação da membrana com o meio de cultura líquido adicionado sobre a mesma. Esse recurso aumentou a sensibilidade em 500 vezes. Para a obtenção do número de bactérias originalmente presentes na amostra, os autores empregaram o tempo de geração média, determinada para alguns microrganismos e relacionaram com o tempo de incubação da membrana. Com essa técnica, após incubação de 6 horas, conseguiram detectar até 6 microrganismos por mililitro.

Em se tratando de análise de água e fluidos intravenosos, a correlação entre o número obtido pelo método de filtração associado a epifluorescência e aquele pelo método de contagem em placas foi alta 58,59 . PALMGREN e colaboradores ${ }^{176}$, também, obtiveram resultados equivalentes quando a amostra era constituída de ar contendo esporos de bolores. Entretanto, a correlação foi baixa para amostras com bactérias.

A aplicabilidade desse método com contagem direta depende intimamente da filtrabilidade da amostra. Mesmo naqueles que são soluções, a 
presença de impurezas suspensas pode saturar os poros, limitando o volume a ser filtrado e consequentemente dirninuindo a sua sensibilidade ${ }^{50,59}$. Além disso, soluções viscosas necessitam de diluição antes de serem submetidas à filtração 138.

A aplicação em amostras líquidas que não são soluções, como por exemplo o leite, exige tratamento prévio, com adição de diluentes contendo tensoativos e tripsina para eliminação de células somáticas e glóbulos de gordura ${ }^{187}$. Segundo PETTIPHER e colaboradores ${ }^{187}$, com essa preparação prévia, a técnica passa a ser adequada para cargas bacterianas de $5 \times 10^{3}$ a $5 \times 10^{8} / \mathrm{mL}$ de leite.

A avaliação da amostra com esse método de observação direta ao microscópio exige contagem de muitos campos. PALMGREN e colaboradores 176 examinaram 40 campos ou 400 células na contagem de bactérias do ar. DENYER e WARD 58 utilizaram a contagem de 10 campos ou 200_células, no máximo de 35 campos.

LARSSON e colaboradores ${ }^{136}$ compararam os resultados obtidos por 3 métodos de contagem direta em águas de lagos: o primeiro, por meio de microscópio comum, na amostra contida em câmaras de $0,1 \mathrm{~mm}$ de profundidade; o segundo através de microscópio de epifluorescência na amostra filtrada e corada com alaranjado de acridina; o último, através de microscopia eletrónica na amostra concentrada por centrifugação, cujo sedimento foi misturado com ágar fundido para obtenção de bloco de gel, por sua vez submetido a tratamento com outros reagentes. Segundo os autores os 3 métodos citados mostraram-se equivalentes.

\subsubsection{Métodos de contagem baseados no metabolismo}

microbiano

- Entre outros métodos alternativos, o elétrico automatizado possibilita a detecção de microrganismos indiretamente por meio de monitoração de metabólitos 40,57,78,92,102,109,138. Como a atividade metabólica dos microrganismos 
presentes no meio de cultura converte moléculas em eletrólitos, o método elétrico baseia-se na mudança de condutividade do meio de cultura, medida antes e após incubação.

A mudança elétrica pode ser avaliada como impedância, medida essa empregada nos métodos automatizados. A impedância permanece praticamente constante e a mudança ocorre quando o número de microrganismos atinge $10^{6}$ a $10^{7}$ organismos por mililitro. O parâmetro de avaliação da carga microbiana na amostra é o tempo requerido para o inóculo inicial atingir o limite de detecção 40,102. Assim, segundo FIRSTENBER-EDEN e TRICARICO ${ }^{79}$, as bactérias psicrófilas e mesófilas do leite podem ser detectadas em 4 horas por esse método.

Visando sua aplicabilidade na análise de cosméticos, LEECH ${ }^{138}$ testou vários artigos de toucador. Segundo o trabalho desse autor, os tempos de detecção foram de 7 a 27 horas, dependendo do produto. O tempo requerido pelas bactérias Gram-negativas não fermentadoras foi equivalente ao tempo de incubação exigido pelo método de contagem de placas. Ainda, alguns microrganismos não produziram eletrólitos suficientes para promover mudança de impedância detectável, em meios de cultura normalmente empregados, como caldos caseína-soja e nutriente.

KAISERMAN e colaboradores ${ }^{117}$, também, testaram esse método para determinação de carga bacteriana em cosméticos. Nesse estudo as amostras foram inoculadas com microrganismos, cujo tempo de geração foi previamente determinado. O número de microrganismos originalmente presente foi obtido relacionado-se o tempo de detecção para mudança de impedância com o tempo de geração do microganismo. Segundo esses autores, o limite mínimo de microrganismo necessário para a detecção foi de $10^{3}$ organismos $/ \mathrm{mL}$ Para amostras com cargas menores sugere a pré-incubação pelo tempo suficiente para atingir essa carga.

A microcalorimetria é outro método automatizado estudado para determinação de microganismos em cosméticos. Inicialmente foi aplicado em laboratórios de análises clínicas para testes de sensibilidade de antibióticos 57, 138. 
O princípio desse método é a detecção de calor produzido pela atividade catabólica microbiana ${ }^{109,138}$. Sua sensibilidade, pelo uso de istrumentos disponíveis, é de $10^{4}$ a $10^{5}$ organismos por mililitro, sendo que o parâmetro de avaliação é o tempo gasto para o inóculo inicial atingir essa carga ${ }^{138}$.

Segudno LEECH ${ }^{138}$, os tempos de detecção foram de 4 e 12 horas para duas amostras de xampus com carga microbiana inicalmente equivalentes, indicando ser o método dependente não somente da carga inicial, mas também, da velocidade de multiplicação.

Outro método baseado na detecção de metabólitos provenientes de atividade microbiana, através de medida de dióxido de carbono marcado foi, sugerido por ANDERSON ${ }^{4}$ para análise de medicamentos.

CUTLER e colaboradores 52 , baseado nesse fundamento, efetuaram a avaliação de atividade antimicrobiana de antibióticos, através de cinética de crescimento. O tempo para a obtenção dos resultados foi em média de 3 horas, empegando-se inóculo de $10^{5}$ bactérias $/ \mathrm{mL}$. Apesar dessa rapidez na obtenção de resultados, segundo JARVIS e EASTER ${ }^{109}$, a limitação da sua aplicação em laboratórios industriais refere-se à utilização de materiais radioativos com seus cuidados e consequências.

\subsubsection{Método de bioluminescência}

A detecção de bioluminescência através da monitoração de adenosina trifosfato (ATP) de microrganismos foi estudado para aplicação em cosméticos e fluidos intravenosos $25,57,138$. O método envolve a detecção de luz emitido pela reação do ATP dos microrganismos com luciferina e luciferase $25,109$. Essa reação é limitada não somente pela carga microbiana, mas também, pela presença de diferentes compostos químicos. A aplicação em análise de medicamentos e cosméticos pode exigir a diluição do produto, em alguns casos até 1:1.000, tornando- 
se compatível somente com amostras com elevada carga microbiana ${ }^{138}$.

\subsection{Compostos empregados na detecção de}

microrganismos

Na procura de métodos que propiciem a obtenção de resultados mais rápidos na detecção e diferenciação de bactérias, novas técnicas tem sido desenvolvidas, baseadas na utilização de substratos cromogênicos ou fluorogênicos. A coloração desses compostos são decorrentes de reações como hidrólise, redução enzimática, de ligação com componentes da célula como os ácidos nucleicos e proteínas e mudança de pH do meio em função da presença de metabólitos bacterianos ${ }^{145}$.

Os corantes que se tornam fluorescentes ou coloridos após hidrólise enzimática são geralmente empregados para contagem seletiva de microrganismos pois para que a reação ocorra é necessário que a enzima esteja presente no microrganismo.

Os derivados do ácido $\beta$-D-glucopiranosiduronico são exemplos de substratos dessa natureza, mais frequentemente utilizados para contagem, tanto em meio sólido como líquido, de bactérias que possuem $\beta$-glucuronidase como a $E$. coli ${ }^{6}$, $14,53,145$.

O diacetato de fluoresceína é outro composto empregado para contagem não seletiva de microrganismos, que se torna fluorescente através de hidrólise 49, 180, 184. A enzima responsável por essa reação é a acetilesterase presente nas células. A fluorescência concentra-se no interior da célula sendo observada por meio de microscópio de epifluorescência ${ }^{35,155}$.

Embora a maioria dos microrganismos seja capaz de desenvolver fluoresceína, MEDZON e BRADY 155 verificaram que das 59 cepas de bactérias testadas, 16 apresentaram resultados negativos. Entretanto, em relação aos bolores e 
leveduras todas, as 22 cepas testadas hidrolizaram o corante.

Segundo estudo de BRUNIUS ${ }^{35}$, o desenvolvimento de fluoresceína pela bactéria depende das condições técnicas de coloração, que devem ser determinadas para cada microrganismo.

Entre os compostos que se tornam fluorescentes em decorrência da ligação com ácidos nucleicos, o alaranjado de acridina e o brometo de etídio foram empregados para contagem de microrganismos $41,48,58,59,138,184,211$. A reação desses corantes com os ácidos nucleicos das células, resulta em aumento de intensidade de fluorescência $54,145$.

O alaranjado de acridina desenvolve fluorescência de coloração diferente em função da ligação ao DNA ou RNA, sendo amarelo-esverdeada com o primeiro e vermelha com o segundo. Esta diferenciação é a base da contagem de microrganismos viáveis em médodos diretos,utilizando-se de microscópio de epifluorescência ${ }^{54}$.

DONKERSLOOT e colaboradores ${ }^{63}$ relata que a quantificação de DNA por meio de reação com brometo de etídio e leitura da fluorescência resultante permite a determinação do número de microrganismos, sendo método tão sensível quanto a nefelometria e 10 vezes mais que a turbidimetria.

PEDRAL 184 e CORREA 49 empregaram a combinação de diacetato de fluoresceína com o brometo de etídio para facilitar a diferenciação de células viáveis das não viáveis de leveduras. Segundo esses autores a técnica com combinação de corantes foi mais sensível que o método de contagem em placas. CALICH e colaboradores ${ }^{41}$, também, obtiveram correlação desse com o método de placas, utlizando-se os 2 corantes, na contagem de leveduras.

Os corantes que são aceptores de hidrogênio são reduzidos quando em presença de microrganismos pela transferência de elétrons ${ }^{65,} 109$. 
O azul de metileno e a resazurina são corantes tradicionalmente empregados para o teste de redução para o leite cru ${ }^{65}$. O primeiro, de coloração azul, torna-se incolor na forma reduzida e a resazurina, de azul para coloração rosa e finalmente incolor ${ }^{65,200}$.

O teste de redução tem a finalidade de, indiretamente, estimar o numero de bactérias, baseando-se no tempo de redução do corante, uma vez que o tempo de redução é inversamente proporcional à carga microbiana ${ }^{65}$. Entretanto, 0 tempo é dependente não somente do número de microrganismos inicialmente presentes, mas também da velocidade de crescimento dos mesmos 200 .

Segundo JOHNS ${ }^{113}$, verificou-se correlação dos resultados obtidos por esse método com aqueles obtidos na contagem em placas. No entanto, no inverno, quando o número de bactérias psicrófilas foi maior, essa relação não foi observada, pois essas reduzem os corantes mais lentamente que as mesófilas.

Apesar das falhas, o teste de redução de corantes continua a ser empregado em detrimento de métodos mais precisos em decorrência da facilidade de execução e baixo custo ${ }^{65}$.

O verde Janus é outro composto, cuja coloração é diferente no estado oxidado e reduzido, sendo aplicado para detecção de microrganismos. Esse corante é verde escuro na forma oxidada; quando reduzido torna-se inicialmente vermelho e passa para incolor. A primeira reação indica quebra do grupo azo e posteriormente a redução do grupo azônio ${ }^{162}$.

Os sais de tetrazólio, também, são compostos que mudam de coloração quando reduzido. Esses são uma das poucas substâncias que são incolores na forma oxidada e coloridas na reduzida ${ }^{149}$.

O cloreto de trifeniltetrazólio (TTC) foi o primeiro sal de tetrazólio a ser sintetizado. A ampla aplicação desse corante na área biológica induziu à síntese de outros sais de tetrazólio, visando obtenção de substâncias com propriedades 
semelhantes ao primeiro ou ainda melhores. O cloreto de neotetrazólio, o seu derivado dimetoxilado, o azul de tetrazólio, e o cloreto de 2-(p-iodofenil)-3-(p-nitrofenil)-5feniltetrazólio foram sintetizados. O neotetrazólio, após redução, torna-se púrpura escura ou preto, o azul de tetrazólio forma pigmento azul e o último, vermelho escuro 224, 267.

Esses corantes apresentam propriedades semelhantes às do TTC e foram empregados para a mesma finalidade, ou seja, detecção de bactérias, determinação de atividade enzimática, determinação de concentração mínima inibitória de antibióticos, testes para verificar viabilidade de tecidos, etc. 55, 133, 199, 261, 268.

Os sais de tetrazólio possuem efeito inibitório sobre o crescimento de microrganismos.

Segundo MAY e colaboradores ${ }^{150}$, os sais de ditetrazólios (neotetrazólio, azul de tetrazólio e azull de nitrotetrazólio) são mais tóxicos para microrganismos que os monotetrazólios (trifeniltetrazólio e iodonitrotetrazólio). Esses autores verificaram, também, que o azul de nitrotetrazólio foi aquele que inibiu maior número de microrganismos em concentrações menores quando comparado a outros sais. Por outro lado, o trifeniltetrazólio foi aquele que apresentou menor atividade inibitória. KORN e KUSHNAREV ${ }^{128}$ comprovaram, também, maior toxicidade do azul de nitrotetrazólio frente à E. coli, S. aureus e B. pseudoanthracis. TENGERDY e colaboradores ${ }^{233}$ igualmente relataram que o azul de tetrazólio é mais tóxico que o trifeniltetrazólio. Segundo esses autores, a concentração do primeiro para provocar redução de $50 \%$ do crescimento de $E$. coli foi de $0,029 \mathrm{mg} / \mathrm{mL}$ e $0,001 \mathrm{mg} / \mathrm{mL}$ para $S$. aureus, enquanto que o trifeniltetrazólio para produzir o mesmo efeito foi, respectivamente, de $0,09 \mathrm{mg} / \mathrm{mL}$ e $0,1 \mathrm{mg} / \mathrm{mL}$

Segundo HURWIT e MC CARTHY 106 solução a $1 \%$ de TTC é auto esterilizante. HUDDLESSON e BALTZER ${ }^{103}$ relataram que bactérias Gramnegativas são mais resistentes à ação inibitória do TTC que as Gram-positivas. Esses autores utilizaram $0,01 \%$ do corante para detecção de bactérias Gram-negativas e 
0,0025\% para as Gram-positivas, por serem essas inibidas em presença de maior concentração.

MAY e colaboradores 150 verificaram, também, mesmo fato. Segundo relato desses autores, essa diferença de comportamento dos 2 grupos de bactérias poderia ser explicada pela semelhança de estrutura dos tetrazólios ao do corante trifenilmetano $\theta$ também pela sua propriedade de reduzir a tensão superficial. A maior permeabilidade das bactérias Gram-positivas aos trifenilmetanos e, também, aos agentes que reduzem a tensão superficial foi comprovada como causa da maior sensibilidade dessas bactérias à ação dos mesmos.

A resistência dos microrganismos ao TTC depende, também, da espécie. NEAL e CALBERT 165 verificaram que bactérias do mesmo gênero são inibidas por concentrações diferentes de TTC. Esses autores citam que Streptococcus thermophilus é inibido por concentrações menores que $1,2 \mathrm{mg} / \mathrm{mL}$ do corante enquanto para S. lactis essa concentração não foi inibitória.

\subsubsection{Cloreto de trifeniltetrazólio}

\subsubsection{Aplicação}

O cloreto de trifeniltetrazólio (TTC)foi sintetizado por PECHMANN e RUNGE ${ }^{181}$ em 1894. Entretanto, a aplicação no campo biológico ocorreu somente após 1941, quando KUHN e JERCHEL ${ }^{130}$ demonstraram que o corante incolor, em presença de material vivo se tomava vermelho. Esses autores demonstraram a redução do TTC por leveduras, bactérias e plantas.

Após 1950 muitas propostas de aplicação biológica do TTC foram objeto de trabalho de vários pesquisadores ${ }^{224}$. Uma das primeiras aplicações do corante foi para verificar a capacidade germinativa de sementes ${ }^{29}$.

A constatação da redução do corante pelas células e tecidos animais como leucócitos humanos, fígado de camundongo, cérebro, músculo, 
cartilagem, etc., conduziram alguns autores ao estudo da reação pelos tecidos neoplásicos $95,149,229$.

Mais recentemente, o TTC é empregado no campo da pesquisa biológica como recurso histológico para determinação da medida de áreas isquêmicas nos estudos experimentais de enfartes cerebrais e de miocárdio em animais $86,107,115$, 124,178

Entre outras aplicações da propriedade de redução do TTC pelos microrganismos pode ser citado o de WOOD ${ }^{261}$, cujo emprego visou a detecção de aglutininas de Brucella sp em leite. Refere-se ao teste de anel que consiste na adição do antígeno corado com TTC, em função do fato de que esse corante não altera a especificidade antigênica da superfície da célula.

Em pesquisas imunológicas, SENTERFIT e JENSEN 218 utilizaram o corante no desenvolvimento de vacinas para verificar a capacidade do anticorpo produzido inibir a replicação de microrganismos. Esses autores justificaram o emprego do TTC com o objetivo de tornar o método mais rápido e simples. O princípio do método baseia-se no fato de que a presença de anticorpos específicos inibe o metabolismo do microrganismo e consequentemente também a redução do corante.

O emprego da propriedade redutora do TTC, como característica de diferenciação de microrganismos, foi proposto através de vários trabalhos 87,103 , $154,209,222,251$.

Segundo HUDDLESON e BALTZER ${ }^{103}$, colônias de diferentes espécies ou variedades da mesma cepa desenvolvem diversas tonalidades de vermelho ou similares quando cultivadas em meio contendo TTC. Entretanto, a coloração da borda é diferente dependendo do microrganismo, sendo mais frequentes o verde, azul, amarelo e vermelho.

GERSHENFELD e WEBER, Jr. ${ }^{87}$ testaram TTC para diferenciação de cepas de Staphylococcus sp, sendo a coloração das colônias diferente para cada 
caso. Foram observadas a coloração vermelha, violeta-avermelhada e amareloalaranjada. Segundo esse autores o corante permite diferenciar estafilococos coagulase-positiva da negativa, pois as primeiras resultam em colónias com coloração laranja na área central, enquanto que outra são de coloração rosa.

Segundo SLANETZ e colaboradores 222 a redução do TTC para coloração marrom pelo Streptococcus faecalis é uma característica que pode ser empregada para diferenciação em relação a outros enterococos. Entretanto, MEAD 154 comprovou que a reação não era específica para S. faecalis. Esse autor testou 201 cepas de enterococos e verificou que algumas, além de $S$. faecalis, também, reduziam - TTC, resultante em colônias com coloração marrom. Da mesma forma encontraram cepas desse microrganismo com reação negativa.

TURNER e colaboradores ${ }^{251}$ propuseram a utilização do TTC para diferenciação de Streptococcus lactis que reduzem o corante da S. cremoris que não o reduz.

LEDERBERG ${ }^{137}$ empregou o TTC para detectar mutantes de $E$. coli que não fermentam carboidratos. O ácido produzido por cepas selvagens inibiram a redução do corante enquanto os mutantes que não produzem ácido foram capazes de desenvolver formazano. ZAMENHOF 265 utilizou o corante de maneira similar para detectar mutante de $E$. coli que não fermentam lactose. Os fermentadores produziram colônias incolores, enquanto que a coloração vermelha foi para os lactose-negativos e rosada para as intermediárias.

USKA e colaboradores ${ }^{140}$ relataram sobre a influência do TTC na produção de ácido láctico pelas bactérias heterofermentadoras. Esses autores sugeriram que a coenzima nicotinamida-adenosina-dinucleotídio reduzida (NADH), requerida na produção de ácido láctico a partir do piruvato, havia sido oxidado pelo TTC.

MATALON e SANDINE 147 propuseram um meio para 
diferenciação de bacilos e cocos em iogurtes. Segundo os autores, no meio suplementado com o TTC o Streptococcus thermophilus se desenvolve em forma de pequenas colônias vermelhas, enquanto o Lactobacillus bulgaricus forma colónias grandes e brancas.

QUEIROZ e colaboradores ${ }^{198}$, também, sugeriram um meio de cultura contendo TTC para isolamento de Campylobacter pylori, para melhor reconhecimento e idenfificação presuntiva desse microrganismo. O uso de discos de papel impregnados com esse corante para identificação dessa espécie foi proposto por RIBEIRO e colaboradores 206.

Outra aplicação desse corante foi proposta por RIOUX e colaboradores 209 para diferenciação de C. albicans de outras leveduras. No meio contendo TTC, as colônias dessa espécie são brancas, enquanto que de outras, de coloração rosa, possibilitam identificação rápida, para fins de diagnóstico.

WOODS e SMITH 262 propuseram a aplicação do TTC para identificação de micoplasma, após incubação em meio seletivo visando a eliminação de sub-cultura.

Outra aplicação atribuída ao TTC foi para a identificação da presença de antibióticos no leite $46,164,165$. O teste baseia-se na inibição de crescimento de Streptococcus thermophilus inoculado ao leite e avaliado pelo grau de redução do corante (intensidade de coloração vermelha), que é inversamente proporcional à concentração do antibiótico.

Para detecção de bacteriófagos lácticos utiliza-se do mesmo princípio, baseado na lise do Streptococcus lactis, inoculado ${ }^{139}$.

A determinação de sensibilidade à antibióticos empregando o TTC foi proposta de JENSEN ${ }^{111}$ para uso em laboratório clínico. Segundo esse autor a diferença no nível de concordância obtida em comparação ao teste de disco em papel no meio de ágar sangue, não permite considerar os 2 métodos equivalentes. 
GIFFORD e BORING 89 e JONHSON e colaboradores ${ }^{114}$, também, recorreram ao mesmo corante para visualização de crescimento microbiano na determinação de MIC de antibióticos em meio líquido. Segundo os primeiros autores os resultados foram obtidos em 10 horas com o método utilizando O TTC enquanto que pelo método padrão foram necessários de 36 a 48 horas, em alguns casos. Esses autores testaram 40 cepas de $S$. aureus contra dicloxacilina e segundo os resultados obtidos, os autores sugerem que o método utilizando o corante pode ser adotado efetivamente para determinação de MIC. No segundo trabalho, os autores empregaram 218 cepas de bactérias Gram-negativas fermentadoras contra 11 antibióticos, onde verificaram $93 \%$ de concordância com o método padrão que consiste na visualização de turvação.

PRATT e DUFRENOY 196 e USDIN e colaboradores 253 empregaram o corante para fins quantitativos. Os primeiros visando a determinação de potência de penicilina com $S$. aureus, enquanto o segundo grupo, para auxiliar a revelação da zona de crescimento microbiano na determinação quantitativa de fatores de crescimento. Segundo os autores, a utilização do corante no método de difusão em ágar é um recurso que aumenta a sensibilidade a níveis obtida no ensaio em meio líquido, com a vantagem sobre esse pela simplicidade e redução de interferência de sais, solventes ou outras substâncias inibitórias. A sensibilidade obtida para o ácido fólico foi de $10^{-6} \mu \mathrm{g}$, possibilitando o ensaio em amostras onde $\mathrm{O}$ fator de crescimento presente ocorre em concentrações extremamente pequenas.

Entre outros estudos envolvendo o mecanismo de reação de redução do TTC está a atividade de desidrogenase. $O$ corante foi utilizado para estudo de atividade dessa enzima em tecidos animais e bactérias como Brucella sp ${ }^{132,}{ }^{156}$, 217.

KUN e ABOOD 132 empregaram o corante na determinação de desidrogenase succínica de tecidos animais por método colorimétrico.

A medida da atividade desidrogenásica dos sistemas de lodo 
ativado por meio de redução do TTC, atuando o mesmo como aceptor artificial de hidrogênio, foi proposta por JONES e PRASAD ${ }^{116}$.

O estudo de fisiologia de cepas de Penicillium chrysogenum, produtoras de penicilina, foi efetuado por FRED e KNIGHT ${ }^{83}$. Esses relacionaram 0 grau de redução de TTC com o estado metabólico das células, concluindo que a produção de penicilina estava na dependência da diminuição de metabolismo celular, durante o qual se verificava menor redução do corante.

O TTC foi empregado, como recurso complementar, na determinação de microrganismos contaminantes em diferentes amostras com características que dificultam a visualização do crescimento microbiano. $\mathrm{Na}$ determinação qualitativa do alto nível de microrganismos contaminantes em leite é sugerido a utilização do TTC para revelação de microrganismos, adicionando-se o corante diretamente na amostra e submetendo à incubação ${ }^{163}$.

$\mathrm{Na}$ contagem de bactérias em alimentos, contendo partículas com baixa carga microbiana em que diluições maiores não podem ser empregadas, é sugerida sua adição ao meio de cultura a fim de garantir a diferenciação entre essas partículas e colônias ${ }^{38}$.

O uso do TTC na avaliação da qualidade microbiana em cosméticos emulsivos, depositando-se pequenas porções da amostra sobre a superfície do meio de cultura sólido contendo o corante, consiste em verificar o nível de contaminação pela intensidade de coloração desenvolvida ${ }^{254}$; ou no caso de amostras com baixa carga contaminante, sua determinação é feita mediante redução no volume do meio e aumento da tomada de ensaio ${ }^{110}$.

Na determinação da carga microbiana contaminante em matériasprimas insolúveis, como $\mathrm{CMC}$, celulose cristalina, etc., utilizados na produção de medicamentos, a adição de TTC no meio de cultura, diminui o tempo dispendido na contagem de colônias elimina a necessidade de lentes de aumento. $O$ corante auxilia 
na diferenciação de colônias das partículas da amostra ${ }^{93}$.

CODY e colaboradores 45 utilizaram o TTC para determinação quantitativa de E. coli e S. aureus, no método para avaliação da eficiência de remoção de microrganismos potencialmente patogênicos, em processos de lavagem de tecidos de uso hospitalar. O método consiste na contagem direta das colónias no tecido, coberto com o meio de cultura adicionado do corante.

Segundo KENNER e colaboradores 119 a contagem de esptreptococos em águas de superfície, seja pela filtração da amostra em membrana ou por semeadura em profundidade, é facilitada pela revelação das colónias com TTC quando esse corante é adicionada aos meios seletivos. KOUJIMA e KANEMASA ${ }^{129}$, também, propuseram o mesmo recurso para melhorar a contagem de enterococos na análise de qualidade sanitária de água, pela técnica de filtração em membrana.

Ainda, entre outras aplicações do TTC, pode ser citada a de HURTWITZ e MC CARTHY 106 em teste de eficiência de conservantes. No aconpanhamento do ensaio através da determinação periódica do nível de germes sobreviventes, esses autores sugerem a substituição do método de contagem em placas pela filtração da amostra. A membrana é inoculada em meio de cultura líquido contendo TTC, seguida de incubação durante 4 a 6 horas. A avaliação consiste na leitura espectrofotométrica do formazano, após extração com butanona.

MATILLA 148 sugere o emprego do TTC como indicador do crescimento bacteriano no teste de atividade de desinfetantes no meio líquido. Segundo o autor, esse método modificado que se baseia na redução do corante, quando comparado àquele que se fundamenta na turvação, é mais rápido e a leitura pode ser efetuada sem utilização de instrumento.

\subsubsection{Mecanismo de reação}

Os sais de tetrazólio são substâncias orgânicas coloridas na forma reduzida, constituindo uma das exceções dentre substâncias orgânicas ${ }^{149}$. 
O cloreto de trifeniltetrazólio pode ser reduzido pela luz, pelas substâncias redutoras como açúcares e ditionito de sódio 108, 116, 167, 258.

Na redução fotoquímica, principalmente pela radiação ultra violeta, resulta o trifenilformazano e uma substância oxidada incolor, denominada foto.TTC.

Essa reação é dependente de pH, ocorrendo mais intensamente em pH alcalino ${ }^{116}$.

Nos organismos vivos, a redução do corante ocorre pela ação de enzimas 22, 33, 112, 116, 131, 149, 156, 172, 209, 219, 224.

A hipótese da ação dos compostos redutores normalmente presentes na células sobre o corante foi descartada, considerando-se $\circ \mathrm{pH}$ em que 0 formazano é desenvolvido "in vitro" a partir da atuação dessas substâncias. Os açúcares reduzem o corante em pH acima de 11 e outros compostos redutores como cisteína, glutationa e ácido ascórbico, em pH acima de 9 130,149.

Em presença de tecidos ou células, a solução incolor de TTC é reduzida a formazano, composto com coloração vermelha, mesmo em pH próximo de 7,0 , pela seguinte reação ${ }^{149}$ :

$\mathrm{C}_{6} \mathrm{H}_{5}-\mathrm{C}=\mathrm{N}-\mathrm{N}-\mathrm{C}_{6} \mathrm{H}_{5}$
$\mathrm{C}=\underset{+}{\mathrm{N}-\mathrm{C}_{6} \mathrm{H}_{5}}$

cloreto de 2,3,5- trifeniltetrazólio

$$
\begin{aligned}
\mathrm{Cl}^{-} \stackrel{+2 \mathrm{e}^{-}+2 \mathrm{H}^{+}}{\longrightarrow} \mathrm{C}_{6} \mathrm{H}_{5}-\mathrm{C}=\mathrm{N}-\mathrm{NH}-\mathrm{C}_{6} \mathrm{H}_{5} \\
\mathrm{~N}=\mathrm{N}-\mathrm{C}_{6} \mathrm{H}_{5}
\end{aligned}
$$$$
+\mathrm{H}^{+} \mathrm{Cl}^{-}
$$

trifenilformazano

MATTSON e colaboradores 149 consideraram os sistemas enzimáticos como responsáveis pela reação "in vivo", em decorrência de observação da perda da capacidade de redução pelos tecidos, quando aquecidos a $82^{\circ} \mathrm{C}$. Observação semelhante foi relatada por GUNZ ${ }^{95}$ quando células ou extrato isento de células de leveduras foram aquecidas a $60^{\circ} \mathrm{C}$. 
Segundo JERCHEL e MOHLE ${ }^{112}$, o potencial redox do TTC é de aproximadamente $-0,08 \mathrm{~V}$. Segundo os autores essa característica possibilita que o corante atue como aceptor de elétrons na presença de muitos piridino-nucleotídiodesidrogenases. Esses mesmos autores observaram a redução do TTC em pH 6,6 pela glicose- desidrogense, em presença de glicose.

KUN 131 estudou a redução do TTC pelas enzimas isoladas de tecidos animais e de leveduras; verificou essa reação com triose-fosfato desidrogenase, mas não pela ação da mitocôndria, quando frutose-1-6-fosfato foi colocado como substrato. Entretanto, ocorreu rápida redução quando foi adicionado mitocondria ao sistema triose-fosfato-desidrogenase e frutose-1-6-fostato. Segundo o autor, para a redução do TTC pelas enzimas glicolíticas necessita-se de um componente presente na mitocondria, que é uma flavoproteina. As aminoácidodesidrogenases, que são flavoproteinas, reduziram o TTC diretamente, sendo a reação mais intensa em anaerobiose.

BRODIE e GOTS ${ }^{33}$ investigaram o efeito do fosfogliceraldeidodesidrogenase e da flavoproteina isolada de leveduras sobre a redução do TTC. Esse corante, no sistema com fosfogliceraldeido e NAD, não alterou a velocidade de redução do NAD e não se verificou o desenvolvimento de formazano. Porém, após adição de flavoproteina houve a redução.

SEVAG e FORBES ${ }^{219}$, no estudo de atividade desidrogenásica em células de $S$. aureus, observaram que o $\alpha$-cetoglutarato é inibidor da reação de redução de TTC em meio contendo glicose e alanina ou glicose e ácido glutâmico. Observaram, também, que o sulfatiazol inibiu o desenvolvimento de coloração, inicialmente. Esse efeito inibitório foi sendo gradualmente reduzdio, demonstrando ser uma inibição competitiva. Segundo os autores, essa observação confirma o mecanismo de ação proposto para redução do TTC, que consiste na transferência de hidrogênio para o corante da flavoproteina reduzida. Esse é o mesmo mecanismo de ação das sulfonamidas sobre as flavoproteinas. 
LISKA e colaboradores 140 estudaram a ação do TTC na conversão da lactose para ácido láctico, pelas bactérias lácticas. Essa reação, por meio da glicólise, envolve ação de NADH que reduz o ácido pirúvico a láctico. Esses autores relataram que o TTC inibe a produção de ácido láctico e consequentemente ocorre o acúmulo do ácido pirúvico. Segundo os mesmos o potencial de oxi-redução do TTC e redução do ácido pirúvico são semelhantes, ocorrendo a competição pelo NADH.

Alguns autores demonstraram que o formazano, produzido pela redução do TTC pelas bactérias e leveduras, localiza-se em grânulos vermelhos intracelulares 156, 157, 162, 258 . Essas estruturas foram apontadas por alguns autores como sendo sítios de redução $156,157,162$.

\section{Segundo MUDD e colaboradores ${ }^{162}$, as áreas de redução} aparecem inicialmente como grânulos redondos que aumentam até o diâmetro atingir o tamanho da célula. O aumento ocorre por um processo de desenvolvimento do composto ao redor de um loco inicial. Esses autores observaram que geralmente grandes grânulos aparecem nos polos das células e as menores no centro, em número de 2 a 4 por célula. A observação desses grânulos, em bactérias e micobactérias, induziram erroneamente sobre a existência de mitocondrias nesses microrganismos.

\section{MELLO e SILVA 156 observaram pontos de maior atividade} enzimática em células de Brucellas sp coradas com TTC. Nas células esses pontos situavam-se numa das extremidades e raramente em duas. Esses autores consideraram, também, a possibilidade de serem essas estruturas, mitocondrias. A mesma possibilidade foi relatada por MERKEL e NICKERSON 157 baseada na observação de que na redução do TTC por $C$. albicans, certos ativadores, particularmente cianeto de potássio e sal dissódico do ácido etilenodiamina tetracético, causaram a dispersão do formazano, insolúvel em água, ao redor das células. Verificaram, macroscopicamente, a liberação de partículas coradas para o exterior, sendo as mesmas idênticas àquelas observadas no interior da célula. WEIBULL 258 provou serem essas conclusões falsas, mostrando que os grânulos eram de 
formazano insolúvel, formado pela coalescência do corante no interior da célula bacteriana. Esses grânulos primários crescem e coalescem em 1 ou 2 partículas maiores. Prova conclusiva foi obtida após rompimento, liberação dos grânulos e sua remoção através de centrifugação. O sobrenadante foi capaz de reduzir o TTC, comprovando não serem essas partículas sítios de redução.

Vários pesquisadores tentaram investigar a relação entre a viabilidade das células e a redução do TTC ${ }^{95,127,} 227$.

GUNZ 95 relatou que células de leveduras reduzem 0 corante prontamente e que a atividade redutora se mantem mesmo nas células não viáveis, bem como nos filtrados de extratos, livres de células. Entretanto, o aquecimento a $60^{\circ}$ C durante 3 períodos de 10 minutos inibiu completamente a reação.

Alguns trabalhos relataram que tecidos e certos microrganismos não reduzem o TTC 119,157,162,172,175, 227.

Segundo STEIN e GERARDE ${ }^{227}$ a reação de redução não é necessariamente uma medida de viabilidade celular, uma vez que a positividade depende da combinação de desidrogenases, além da necessidade de penetração do TTC para o interior da célula, através da membrana celular.

As investigações de KOPPER ${ }^{127}$ acrescentaram outros dados, como a de que $o$ aquecimento da suspensão microbiana a $46-56^{\circ} \mathrm{C}$ durante 10 minutos ou a exposição da mesma a agentes antimicrobianos provocaram perda de atividade redutora, que por sua vez foi diretamente proporcional à diminuição de viabilidade. Em culturas de células jovens essa redução foi mais acentuada que para aquelas de 18 horas, estando a diminuição da reação intimamente relacionada com o número de células viáveis em culturas jovens. Entretanto, para culturas de 18 horas essa relação não foi observada, para $\circ$ que $\bigcirc$ autor sugere ser decorrente do aumento de permeabilidade celular naquelas mais velhas.

KENNER e colaboradores ${ }^{119}$ testaram 21 espécies dentre os 
gêneros Streptococcus, Pediococcus, Leuconostoc e Lactobacillus em meio de cultura contendo TTC para verificar a capacidade de redução desses microrganismos. Dentre essas as culturas de Pediococcus cerevisiae e Lactobacillus plantarum não formaram colônias coloridas. PAGANO e colaboradores ${ }^{175}$, também, testaram algumas espécies de leveduras e constataram que apenas $C$. albicans não reduziu o corante, enquanto outras espécies testadas formaram colónias rosadas em meio com TTC. RIOUX e colaboradores 209 testaram 23 leveduras ascosporadas e 19 anascosporadas e verificaram que além de $C$. albicans, Pichia fermentans, C. rugosa e C. krusei não formaram colônias coloridas.

RAUT 201 observou que colónias de leveduras quando irradiadas com radiação ultra violeta perderam a capacidade de reduzir o TTC. Segundo o autor, ocorre deficiência no sistema de citocromos. OGUR e colaboradores ${ }^{172}$ após testarem 100 leveduras, sendo metade com respiração suficiente e o restante deficiente, verificaram que até 3 horas após adição de TTC nas colônias já formadas, manteve-se a diferenciação dos 2 grupos. Após esse período algumas células com respiração deficiente tornaram-se levemente rosadas, aumentando esse número após 24 horas. RIOUX e colaboradores ${ }^{209}$, também, verificaram que cepas que normalmente reduzem - TTC quando cultivadas em meio contendo esse corante podem gerar mutantes sem essa capacidade.

Outras substâncias como edetato de sódio e cianeto de potássio possuem ação mutagênica sobre a característica redutora de TTC, fato observado por MERKEL e NICKERSON ${ }^{157}$ em C. albicans.

Segundo RIOUX e colaboradores ${ }^{209}$ a hipótese da redução do TTC, como resultado do equilíbrio entre o metabolismo fermentativo e respiratório, não justifica a ausência de redução em leveduras de metabolismo oxidativo muito ativo como C. albicans e em leveduras com respiração deficiente. Para esses autores as leveduras que não reduzem TTC possuem em comum ausência de sistema enzimático específico. 
TENGERDY e colaboradores ${ }^{233}$ relataram que somente bactérias em crescimento reduzem o TTC, tendo se baseado em resultados obtidos com culturas cuja carga inicial era de $10^{4}$ e $10^{7}$ cólulas em que não foram detectadas quantidades significativamente diferentes de formazano. Obsrvação semelhante foi citada por FRED e KNIGHT ${ }^{83}$ para Penicillium chrysogenum. Em culturas com 1 a 3 dias, período no qual a velocidae de metabolização é alta, a redução do corante também ocorreu rapidamente. Consequentemente, a velocidade de redução foi menor em culturas com maior tempo de incubação, não ocorrendo a reação em culturas com 8 dias.

KOPPER $^{127}$ testou suspensões de E. coli resultantes da incubação durante 4 e 18 horas quanto à atividade redutora, avaliado através da quantidade do formazano. A constatação desse experimento corrobora as conclusões de outros pesquisadores, pois na cultura de 4 horas, apesar do número menor de células (10 10 células) houve formação de 170 a $200 \mu \mathrm{g}$ de formazano, enquanto que $3 \times 10^{10}$ células, resultante da incubação de 18 horas, formou 80 a $110 \mu \mathrm{g}$.

Além da idade ds células, a redução do TTC é influenciada pelos fatores do meio.

NICKERSON e MERKEL 167 verificaram que suspensões de algumas leveduras com 72 horas de incubação não reduziram o TTC no escuro, enquanto que para culturas jovens, esses autores não observaram diferença decorrente da luminosidade. Segundo os mesmos autores os inibidores de redução de TTC foram mais efetivos no escuro que na presença de luz. Os íons metálicos são inibidores de redução de TTC, pois esses estabilizam o corante contra foto-redução. Assim, a adição de edetato de sódio e cianeto de sódio que apresentam ação quelante aumentam a redução do TTC.

KUN e ABOOD 132 investigaram a determinação de desidrogenase-succínica em homogenizado de fígado de ratos, utilizando TTC. Encontraram diferença considerável na velocidade de redução em função dos meios serem em aerobiose ou anaerobiose. Em outro trabalho, KUN 131 verificou que 
soluções de flavoproteinas com aminoácido-desidrogenase de tecidos animais transferem elétrons para TTC sob condições anaeróbicas. Segundo o autor, a diminuição da redução pelos aminoácido-desidrogenases em aerobiose é provavelmente devido ao mecanismo de competição com oxigênio e o TTC. JONES e PRASAD ${ }^{116}$, também, relataram que o oxigênio molecular é competidor direto na função de aceptor de hidrogênio, em microrganismos. A reação atinge o mesmo nível em aerobiose como em anaerobiose, porém, na primeira condição o tempo necessário é maior, caracterizando a inibição competitiva.

Segundo BRODIE e GOTS ${ }^{33}$, na reação do TTC com flavoproteina e $\mathrm{NADH}$, a quantidade de formazano produzido em aerobiose foi muito pequena e ocorreu em faixa estreita de $\mathrm{pH}(7,5$ a 8,3$)$, quando comparado com a reação em anaerobiose. Os autores justificam essa diferença em função da elevação do potencial de oxi-redução para nível não favorável, com competição entre o oxigênio e TTC pela flavoproteina ou envolvimento de outros mecanismos na redução aeróbica de TTC.

MELO e SILVA 156 verificaram que a redução de TTC depende não somente do microrganismo, mas também, do substrato. Esses autores testaram duas espécies de Brucella frente a diferentes carboidratos, aminoácidos e álcoois. De uma forma geral os compostos foram oxidados mais intensamente pelo $B$. suis que pelo B. abortus. Na presença de D-xilose, L-arabinose, D-glicose, D-galactose e maltose a quantidade de formazano obtido foi maior que em tampão com D-frutose. Não foi observado oxidação de D-lactose pois não se verificou diferença na redução do TTC entre os meios adicionados de tampão contendo esse açúcar e o controle. Larabinose, D-galactose, D-glicose e D-xilose e D-frutose foram oxidados pelo $B$. abortus enquanto lactose e maltose não foram utilizados. Segundo os autores, entre os aminoácidos, somente a alanina promoveu redução intensa do corante enquanto Darginina, L-asparagina, D-ácido glutâmico e glicina não acentuaram a reação.

Em trabalho de SEVAG e FORBES ${ }^{219}$ houve demonstração de 
que a adição de glicose e aminoácidos aumentou a redução de TTC pelo $S$. aureus, cuja atividade foi limitada quando isoladamente adicionados ao meio.

BARTLEIT e colaboradores ${ }^{16}$, porém, verificaram que a adição de glicose isoladamente no meio de cultura na concentração de $0,5 \%$ acentuou a produção de formazano. Os mesmos autores demonstraram que o metosulfato de fenazina e o ágar também possuem a propriedade de acelerar a redução do TTC. Segundo os pesquisadores, baseado no trabalho de DICKENS e MC ILWAIN ${ }^{61}$, a ação do primeiro composto é explicado pelo fato de ser esse um transportador de elétrons, que poderia ser substituto de flavoproteina. A adição de ágar na concentração de $0,05 \%$ e $0,08 \%$ aumentou a redução do corante, porém na concentração de $0,1 \%$ o efeito observado foi contrário. 


\section{MATERIAL E MÉTODOS}

\subsection{Material}

O material, objeto deste estudo, consistiu de meios de cultura, reagentes, especialidades farmacêuticas, produtos cosméticos e microrganismos padrões, a saber:

\subsubsection{Meios de cultura}

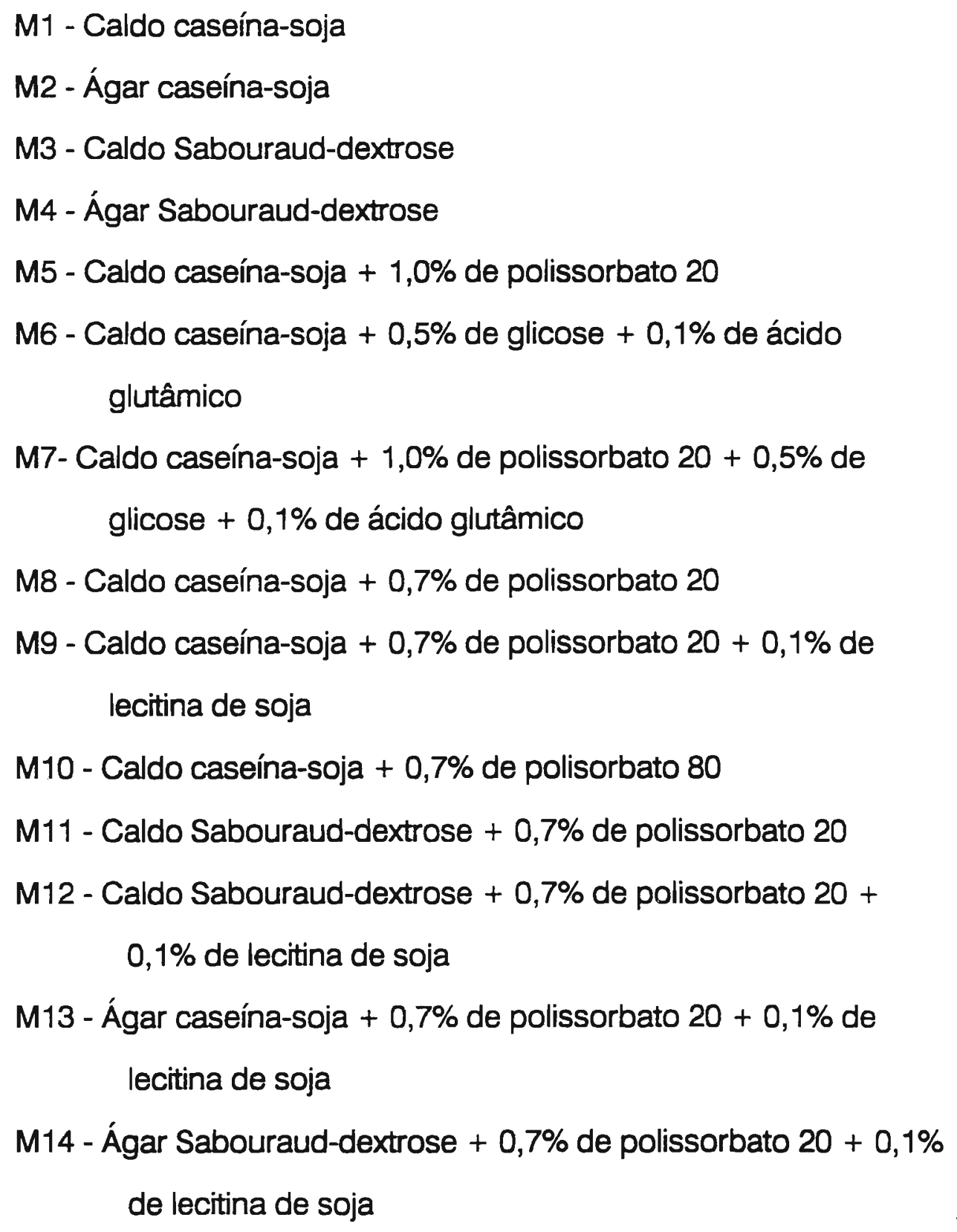




\subsubsection{Reagentes}

R1 a R7 - Solução de cloreto de 2, 3, 5-trifeniltetrazólio (TTC) a $0,25,0,5,1,0,1,2,2,0,5,0$ e 10,0\% em água destilada

R8 a R14 - Ágar bacteriológico a 1,0\% em água destilada com $0,025,0,05,0,1,0,2,0,5,1,0$ e $2,0 \%$ de TTC

R15 a R19 - Ágar bacteriológico a 1,0\% em tampão fosfato pH 7,5 com $0,1,0,2,0,5,1,0$, e 2,0\% de TTC

R2O - Solução aquosa de hidróxido de alumínio a 6,0\%

R21 - Solução aquosa de hidróxido de sódio 2 N

R22 - Solução fisiológica estéril

\subsubsection{Especialidades farmacêuticas}

Amostras de especialidades farmacêuticas, adquiridas em farmácias e drogarias de São Paulo, conforme a fórmula declarada:

F1 - Suspensão de hidróxido de alumínio a 6,1\%, fabricante $A$ Hidróxido de alumínio $930 \mathrm{mg}$ Veículo q.s.p. $15 \mathrm{~mL}$

F2 - Suspensão de hidróxido de alumínio a 6,1\%, fabricante B F3 - Suspensão de pectina

Caolim $2,96 \mathrm{~g}$

Pectina $0,07 \mathrm{~g}$ Veículo q.s.p. $15 \mathrm{~mL}$ 
F4 - Suspensão de eritromicina

Eritromicina (estearato) $\quad 250 \mathrm{mg}$

Veículo q.s.p. $\quad 10 \mathrm{~mL}$

F5 - Suspensão de metronidazol

Benzoilmetronidazol $200 \mathrm{mg}$

Veículo q.s.p. $\quad 5 \mathrm{~mL}$

F6 - Suspensão de fosfato tricálcico a 1,0\%

Fosfato tricáicico $\quad 150 \mathrm{mg}$

Vitamina D $562,5 \mathrm{UI}$

Fluoreto de sódio $\quad 1,5 \mathrm{mg}$

Suspensão coloidal q.s.p. $\quad 15 \mathrm{~mL}$

\subsubsection{Produtos cosméticos}

Amostras de produtos cosméticos adquiridos em farmácias, drogarias ou lojas especializadas de São Paulo:

C1 - Creme hidratante

C2 - Creme condicionador de cabelos, fabricante A

C3 - Creme condicionador de cabelos, fabricante B

C4 - Creme condicionador de cabelos, fabricante C

C5 - Loção hidratante, fabricante D

C6 - Loção hidratante, fabricante E

\subsubsection{Suspensão de microrganismos padrões}

Mi1 - Staphylococcus aureus ATCC 6538

Mi2 - Staphylococcus epidermidis ATCC 12228

Mi3 - Micrococcus /uteus ATCC 9341

Mi4 - Micrococcus flavus ATCC 14552

Mi5 - Bacillus subtilis ATCC 6623 


\author{
Mi5 - Bacillus subtilis ATCC 6623 \\ Mi6 - Bacillus pumilus ATCC 14884 \\ Mi7 - Pseudomonas aeruginosa ATCC 15442 \\ Mi8 - Escherichia coli UC 677 \\ Mi9 - Candida albicans ATCC 10231 \\ Mi10 - Sacharomyces cerevisiae ATCC 2601 \\ Mi11 - Sacharomyces cerevisiae ATCC 9763
}

\title{
4.2 Métodos
}

\subsubsection{Preparação dos meios de cultura (M1 a M14)}

Os meios caldo e ágar caseína-soja e Sabourad-dextrose foram preparados a partir do meio desidratado, conforme instrução do fabricante (Difco).

O polissorbato 20 e 80 (Atlas) e a lecitina de soja (Veado d'Ouro) foram adicionados, antes da esterilização, dissolvidos na água destilada empregada para a preparação dos meios.

Os meios contendo glicose $e$ ácido glutâmico foram preparados da seguinte maneira:

- o meio de cultura desidratado foi dissolvido em água destilada, com volume correspondente a $90 \%$ daquela recomendada pelo fabricante;

- a glicose e o ácido glutâmico, sob a forma de solução aquosa, respectivamente, a 5,0 e 1,0\% previamente esterializada por filtração através de membrana de ésteres de celulose, de porosidade de 0,45 $\pm 0,02 \mu \mathrm{m}$ e 47,0 $\mathrm{mm}$ de diâmetro, em unidades filtrantes individuais (Millipore), foram adicionados ao meio de cultura esterilizado, respeitando a proporção volumétrica de $10 \%$. 


\subsubsection{Preparação de ágar bacteriológico a 1,0\% com trifeniltetrazólio} (R8 a R14)

A dispersão de ágar bacteriológico (Difco) a 1,0\% (p/v) em água destilada foi submetida à esterilização em autoclave a $121^{\circ} \mathrm{C}$ durante 15 minutos.

O cloreto de trifeniltetrazólio (Sigma) foi adicionado ao ágar fundido na quantidade necessária para obter as concentrações de 0,025, 0,05, 0,1, 0,5, 1,0 e $2,0 \%(\mathrm{p} / \mathrm{v})$ e a mistura foi aquecida até fervura e resfriada para aproximadamente $48^{\circ} \mathrm{C}$.

Para a preparação do ágar em tampão fosfato $\mathrm{pH} 7,5$ foi empregado o mesmo procedimento, substituindo-se a água destilada para dispersão do ágar por tampão fosfato pH 7,5 . O TTC foi adicionado a fim de obter as concentrações de $0,1,0,2,0,5,1,0$ e 2,0\% (p/v) (R15 a R19).

\subsubsection{Preparação das soluçōes de cloreto de trifeniltetrazólio}

As soluções aquosas de cloreto de trifeniltetrazólio foram preparadas a partir de quantidade suficiente deste sal (Sigma) em água destilada a fim de obter $1,0,2,0,5,0$, e $10 \%(p / v)$.

As soluções foram esterilizadas através de filtração em membranas de ésteres de celulose, porosidade 0,45 $\pm 0,02 \mu \mathrm{m}$ e diâmetro de $47 \mathrm{~mm}$, em unidades filtrantes individuais (Millipore).

As soluções com concentrações menores de TTC foram obtidas a partir da solução a 1,0\% por meio de diluições com água destilada estéril.

\subsubsection{Preparação de suspensão aquosa de hidróxido de alumínio a $6,0 \%$}

Quantidade suficiente de hidróxido de alumínio, grau farmacêutico, foi adicionada em água destilada para obter suspensão a 6,0\% $(p / v)$ e esterilizada em autoclave a $121^{\circ} \mathrm{C}$, durante 15 minutos. 


\subsubsection{Preparação da solução aquosa de hidróxido de sódlo $2 \mathrm{~N}$}

A solução foi preparada com hidróxido de sódio p.a. (Merck) $(9,0$ g) em água destilada (100 mL) e esterilizada em autoclave a $121^{\circ} \mathrm{C}$, durante 15 minutos.

\subsubsection{Preparação de solução fisiológica}

A solução foi preparada com cloreto de sódio p.a. (Merck) na concentração de $0,9 \%$ em água destilada e submetida à esterilização em autoclave a $121^{\circ} \mathrm{C}$, durante 15 minutos.

\subsubsection{Preparação da suspensão de bactérias}

Todas as espécies bacterianas foram cultivadas em meio inclinado de ágar caseína-soja (M2) incubando-se os tubos em estufa a $36,0 \pm 1,0^{\circ} \mathrm{C}$, durante 2 horas.

A massa celular resultante do crescimento foi recolhida em $9,0 \mathrm{~mL}$ de solução fisiológica estéril e a suspensão obtida foi submetida à contagem de organismos viáveis, pela técnica de semeadura em profundidade. Para isto, foram efetuadas diluições decimais seriadas até $10^{-7} \mathrm{em} \mathrm{9,0} \mathrm{mL} \mathrm{de} \mathrm{solução} \mathrm{fisiológica} \mathrm{estéril.}$ Alíquotas de 1,0 $\mathrm{mL}$ das diferentes diluições foram transferidas para placas de Petri, em duplicata e homogeneizadas com $15 \mathrm{~mL}$ de ágar caseína-soja (M2), esterilizada e mantida a cerca de $48^{\circ} \mathrm{C}$. Após incubação das placas em estufa a $36,0 \pm 1,0^{\circ} \mathrm{C}$, durante 48 horas, foi efetuada a contagem de colônias, empregando-se contador de colônias Quebec $^{R}$.

O número de unidades formadoras de colônias por mililitro (UFC/mL) da suspensão foi determinada a partir de placas que acusaram contagem de 30 a 300. 


\subsubsection{Preparação da suspensão de leveduras}

As leveduras foram cultivadas em meio inclinado de ágar Sabouraud-dextrose (M4), incubando-se os tubos em estufa a $20-25^{\circ} \mathrm{C}$, durante 48 horas.

O procedimento para obtenção da suspensão e determinação da $\mathrm{UFC} / \mathrm{mL}$ foi o mesmo utilizado para bactérias (item 4.2.7), diferindo no tocante ao meio de cultura e condições de incubação.

\subsubsection{Determinação da concentração mínima inibltória do cloreto de trifeniltetrazólio 48}

A concentração mínima inibitória foi determinada para os seguintes microrganismos: Staphylococcus aureus ATCC 6538, Micrococcus luteus ATCC 9341, Micrococcus flavus ATCC 14552, Bacillus subtilis ATCC 6623, Bacillus pumilus ATCC 14884, Pseudomonas aeruginosa ATCC 15442 e Escherichia coli UC 677.

A partir da suspensão de cada microrganismo, de concentração conhecida (item 4.2.7), foram efetuadas diluições necessárias com solução fisiológica estéril para se obter $10^{3}, 10^{2}$ e $10 \mathrm{UFC} / \mathrm{mL}$

Alíquotas de $1 \mathrm{~mL}$, de cada uma destas, foram inoculadas para réplicas de 3 tubos contendo $10 \mathrm{~mL}$ de caldo caseína-soja (M1) e para 3 outras séries de triplicata adicionadas de cloreto de trifeniltetrazólio. A concentração final deste corante, no meio de cultura, foi de 30,60 e $120 \mu \mathrm{g} / \mathrm{mL}$. Para isto, a partir da solução aquosa concentrada contendo $12 \mathrm{mg} / \mathrm{mL}$ foram transferidas alíquotas de $0,25,0,5$ e 1,0 mL para cada $100 \mathrm{~mL}$ do caldo caseína-soja (M1).

Todos os tubos correspondentes ao teste com um determinado microrganismo foram simultaneamente incubados em estufa, a $33 \pm 1^{\circ} \mathrm{C}$, observando se diariamente até 72 horas, quanto ao aparecimento da turvação, suspendendo-se a 
incubação após a constatação do crescimento nos tubos sem o corante, no decorrer deste período. O grau de turbidez, representando por cruz, foi atribuído de forma relativa dentro de cada microrganismo teste.

\subsubsection{Verificação da influência do inóculo, aditivos ao meio de cultura e concentração do cloreto de trifeniltetrazólio no desenvolvimento da coloração}

Os sistemas testados (Tabela I) apresentaram como componentes, o caldo caseína-soja (M1) e o mesmo acrescido de:

- polissorbato $20(1,0 \%)(M 5)$

- glicose $(0,5 \%)$ e ácido glutâmico $(0,1 \%)(M 6)$;

- polissorbato 20, glicose e ácido glutâmico nas concentrações anteriores (M7).

Cada um destes sistemas, por sua vez, foi adicionado de 3 ou 4 diferentes concentrações de cloreto de trifeniltetrazólio $(0,25,0,5,1,0$ e 2,0\%).

O procedimento para a preparação das soluções do corante foi conforme item 4.2.3. As concentrações finais de $250,500,1000$ e $2000 \mu \mathrm{g} / \mathrm{mL}$ foram obtidas transferindo-se de cada solução do corante, alíquotas de $0,5 \mathrm{~mL}$ para tubo contendo $4,5 \mathrm{~mL}$ de meio, com ou sem outros reagentes mencionados.

As suspensões de $S$. aureus e de $P$. aeruginosa com $10^{9} \mathrm{UFC} / \mathrm{mL}$, obtidas segundo item 4.2.7, foram submetidas à diluição decimal seriada, em solução fisiológica estéril, de modo que alíquotas de $0,5 \mathrm{~mL}$ da suspensão quando adicionada ao meio correspondesse ao inóculo deste ensaio. Os inóculos testados foram $10^{5}$ a $10^{8}$ $\mathrm{UFC} / \mathrm{ml}$.

Todos os tubos foram incubados em estufa a $33 \pm 1^{\circ} \mathrm{C}$ observando-se a mudança de coloração no meio líquido com a vista desarmada (macroscopicamente), após 1, 2 e 4 horas. 
TABELA I. Combinação de variáveis do meio de cultura para verificação da sua influência frente a diferentes concentrações de TTC.

\begin{tabular}{|c|c|c|c|c|c|c|c|c|}
\hline \multirow[t]{2}{*}{ Sistema } & \multirow{2}{*}{$\begin{array}{l}\text { Caldo } \\
\text { caseína- } \\
\text { soja }\end{array}$} & \multirow{2}{*}{$\begin{array}{l}\text { Polissor- } \\
\text { bato } 20 \\
(1,0 \%)\end{array}$} & \multirow{2}{*}{$\begin{array}{l}\text { Glicose } \\
(0,5 \%)\end{array}$} & \multirow{2}{*}{$\begin{array}{l}\text { Ác. glu- } \\
\text { tâmico } \\
(0,1 \%)\end{array}$} & \multicolumn{4}{|c|}{$\overline{\overline{T T C}(\mathrm{mg} / \mathrm{mL})}$} \\
\hline & & & & & $\overline{0,25}$ & 0,50 & 1,0 & 2,0 \\
\hline 1 & $x$ & & & & $x$ & & & \\
\hline 2 & $x$ & & & & & $x$ & & \\
\hline 3 & $x$ & & & & & & $x$ & \\
\hline 4 & $x$ & & & & & & & $x$ \\
\hline 5 & $x$ & $x$ & & & $x$ & & & \\
\hline 6 & $x$ & $x$ & & & & $x$ & & \\
\hline 7 & $x$ & $x$ & & & & & $x$ & \\
\hline 8 & $x$ & & $x$ & $x$ & $x$ & & & \\
\hline 9 & $x$ & & $x$ & $x$ & & $x$ & & \\
\hline 10 & $x$ & & $x$ & $x$ & & & $x$ & \\
\hline 11 & $x$ & & $x$ & $x$ & & & & $x$ \\
\hline 12 & $x$ & $x$ & $x$ & $x$ & $x$ & & & \\
\hline 13 & $x$ & $x$ & $x$ & $x$ & & $x$ & & \\
\hline 14 & $x$ & $x$ & $x$ & $x$ & & & $x$ & \\
\hline
\end{tabular}


Análise semelhante foi efetuada com os mesmos sistemas, apenas variando o tamanho do inóculo e aumentando o tempo de incubação para 20 horas, a $33 \pm 1{ }^{\circ} \mathrm{C}$. Neste caso, $S$. aureus e $P$. aeruginosa foram testados a $10^{6}$ e $10^{5} \mathrm{UFC} / \mathrm{mL}$.

O procedimento analítico aplicado para M. flavus, S. epidermidis, B. subtilis e M. Iuteus foi semelhante, frente aos sistemas 2, 3, 6, 7, 13 e 14 (Tabela I), com incubação de até 4 horas, com inóculo de $10^{8}$ e $10^{7} \mathrm{UFC} / \mathrm{mL}$.

Tubos controle de todos os sistemas, sem o inóculo, foram submetidos às mesmas condições do teste.

A observação macroscópica foi no sentido de efetuar comparações dentro de cada variável frente a 3 ou 4 concentrações diferentes do corante, assim como a comparação foi entre as variáveis para a mesma concentração de TTC para um determinado tempo de incubação.

\subsubsection{Comparação entre a técnica de tubos múltiplos com sub-cultura}

e emprego de cloreto de trifeniltetrazólio na detecção de microrganismos viáveis

Tanto as cepas padrões de bactérias como de leveduras foram submetidas ao teste. Para isto, seguindo o procedimento dos itens 4.2.7 e 4.2.8, foram obtidas suspensões de cada microrganismo, com $100 \mathrm{UFC} / \mathrm{mL}$ para bactérias e 10 e $100 \mathrm{UFC} / \mathrm{mL}$ para leveduras. A partir de cada uma das 3 suspensões foram efetuadas as diluições $10^{-1}$ e $10^{-2}$, com solução fisiológica estéril e todas, inclusive aquela sem diluição, serviram como inóculo do teste de tubo múltiplo.

Os meios de cultura para bactérias foram caldo caseína-soja (M1), este adicionado de polissorbato $20(0,7 \%)(M 8)$ e este último acrescido de lecitina de soja $(0,1 \%)$ (M9). No caso de leveduras o meio foi de caldo Sabouraud-dextrose (M3) e este contendo as mesmas substâncias, nas concentrações iguais às empregadas para bactérias (M11 e M12). 
Cada microrganismo foi testado frente aos 3 meios de cultura, sendo que cada caso em 18 tubos contendo $9 \mathrm{~mL}$, de modo que alíquotas de $1 \mathrm{~mL}$ de cada diluição do inóculo foram transferidas para réplicas de 6 tubos.

Os tubos com bactérias foram incubados em estufa a $33 \pm 1^{\circ}$ durante 20 horas e aqueles com leveduras, a $20-25^{\circ} \mathrm{C}$ por 72 horas, após o que foram observados macroscopicamente quanto à intensidade de turvação.

De cada tubo, após a homogeneização manual, foi transferida uma alçada para $5 \mathrm{~mL}$ de caldo caseína-soja (M1) ou caldo Sabouraud-dextrose (M2), respectivamente para bactérias e leveduras.

Os tubos correspondentes à sub-cultura de bactérias foram incubadas em estufa à $33 \pm 1^{\circ} \mathrm{C}$ e a observação da turvação foi após 5,18 e 48 horas Para as leveduras a temperatura de incubação foi a $20-25^{\circ} \mathrm{C}$ e a observação, após 18 , 24 e 48 horas.

Após retirada da amostra para semeadura em sub-culturas, foi adicionada à série de tubos originais solução de $T T C \mathrm{com} 10 \mathrm{mg} / \mathrm{mL}$. Para a metade dos 6 tubos de cada série foi transferida a alíquota de $0,5 \mathrm{~mL}$ e para outra metade, 0 dobro da solução do corante por tubo.

O procedimento para os tubos inoculados com a suspensão de levedura contendo $10 \mathrm{UFC} / \mathrm{mL}$ e as 2 diluições decimais, obtidas a partir desta, foi diferente. Alíquotas de $5 \mathrm{~mL}$ foram retiradas dos tubos originais e transferidas para tubos vazios, para os quais foram adicionados volumes de 0,25 e 0,5 mL da solução de TTC. Os tubos originalmente inoculados foram novamente incubados nas condições anteriores por mais 24 horas.

A observação macroscópica dos tubos quanto à intensidade de coloração no caso de bactérias foi após 1, 2, 3 e 18 horas de incubação em estufa à 33 $\pm 1^{\circ} \mathrm{C}$ e naqueles com leveduras, após $1,2,4$ e 18 horas a $20-25^{\circ} \mathrm{C}$. 
A intensidade de turvação e da coloração nos tubos originais foi representada por número de cruzes, atribuído de forma relativa dentro de cada microrganismo, usando o meio não inoculado como controle.

As sub-culturas foram observadas quanto à presença de turvação que foi representada por cruz.

\subsubsection{Detecçáo de Candida albicans pela técnica de tubos múltiplos com sub-cultura e pela reduçáo do cloreto de trifeniltetrazólio em meio alcalinizado}

Suspensão C. albicans com 100, 10 e 1 UFC/mL foram obtidas segundo procedimento descrito no item 4.2.8.

Alíquotas de $1 \mathrm{~mL}$ de cada concentração do microrganismo foram transferidas para 18 tubos contendo $9 \mathrm{~mL}$ de caldo Sabouraud-dextrose (M3) e para igual número de tubos com o mesmo meio adicionado de $0,7 \%$ de polissorbato 20 (M11).

Após incubação de 72 horas em estufa a $20-25^{\circ} \mathrm{C}$ foi observada a intensidade de turvação do crescimento nos tubos e a seguir foram efetuadas subculturas, transferindo-se uma alçada de todos os tubos para igual número de tubos contendo $5 \mathrm{~mL}$ de caldo Sabouraud-dextrose (M3) e os mesmos incubados em estufa a $20-25^{\circ} \mathrm{C}$.

Após procedimento anterior, os 18 tubos originais, correspondentes a um determinado inóculo e meio de cultura, foram divididos em 3 grupos de 6. Para 3 tubos de cada grupo foi acrescido $0,5 \mathrm{~mL}$ de solução aquosa estéril de hidróxido de sódio $2 \mathrm{~N}$ por tubo. A seguir, alíquotas de $0,5 \mathrm{~mL}$ da solução aquosa estéril de cloreto de trifeniltetrazólio a 2\% (R5), $5 \%$ (R6) e 10\% (R7) foram adicionadas, respectivamente, para cada grupo. A preparação das soluções de TTC foi segundo as condições descritas no item 4.2.3. 
A leitura da intensidade de coloração foi efetuada com a vista desarmada, 2 horas após a adição de TTC.

A avaliação da sub-cultura, tendo como parâmetro a turvação, foi após 48 horas de incubação.

\subsubsection{Avaliaçáo da atividade inibitória do polissorbato 20 e 80 e da lecitina de soja adicionados ao meio de caseína-soja}

As suspensões com $10^{2} \mathrm{UFC} / \mathrm{mL}$ de $S$. aureus, $S$. epidermidis e $M$. luteus foram preparadas seguindo o procedimento do item 4.2.7. Estas suspensões foram submetidas à diluição decimal até $10^{-2} \mathrm{em}$ solução fisiológica estéril.

Cada suspensão de microrganismo foi inoculado no meio de caldo caseína-soja (M11), o mesmo adicionado de 0,7\% de polissorbato 80 (M10) ou 20 (M8), e o último mais lecitina de soja na concentração de 0,1\% (M9). Para isto, alíquotas de 1 $\mathrm{mL}$ de cada suspensão foram transferidas para 10 tubos contendo $9 \mathrm{~mL}$ de cada um dos meios de cultura.

A incubação foi $a 33 \pm 1^{\circ} \mathrm{C}$, com observação visual da turvação após 20, 24 e 48 horas.

4.2.14 Determinação da concentração mínima eficaz do cloreto de trifeniltetrazólio para revelação de colónias bacterianas

Suspensão de $S$. aureus, $B$. subtilis, $P$. aeruginosa e $E$. coli com cerca de 50 UFC/mL foram preparadas conforme técnica descrita no item 4.2.7.

Alíquotas de $1 \mathrm{~mL}$ de cada suspensão foram pipetadas para 16 placas de Petri, sendo que para a metade foram transferidos $15 \mathrm{~mL}$ de ágar caseínasoja (M2) fundida e mantida a cerca de $48^{\circ} \mathrm{C}$, e para o restante, $20 \mathrm{~mL}$, seguido de homogeneização manual. 
O mesmo procedimento foi efetuado, empregando-se ágar caseína-soja com $0,7 \%$ de polissorbato 20 e $0,1 \%$ de lecitina de soja (M13).

Após incubação das placas em estufa a $33 \pm 1^{\circ} \mathrm{C}$ durante 48 horas a superfície do meio de cultura foi coberta com $5 \mathrm{~mL}$ de ágar bacteriológico a $1 \%$, fundido, contendo diferentes concentrações do corante e mantido a temperatura de cerca de $48^{\circ} \mathrm{C}$. Sua preparação foi conforme o procedimento descrito no item 4.2.2, de modo a obter as seguintes concentrações: $0,025,0,05,0,1$ e 0,2\% (p/v) (R8 a R11).

Para cada microrganismo, volume e composição do meio de cultura foram testadas 2 placas frente a cada concentração do corante.

A observação macroscópica da coloração das colônias localizadas sobre a superfície do gel e daquelas próximas ao fundo da placa foi após 15, 30 e 60 minutos a partir da aplicação do reagente, sendo que as placas foram reincubadas a 33 $\pm 1^{\circ} \mathrm{C}$.

\subsubsection{Determinação da concentração mínima eficaz do cloreto de trifeniltetrazólio para revelação de colônias de leveduras}

O procedimento foi o mesmo adotado para bactérias (item 4.2.14), empregando-se culturas de $C$. albicans e $S$. cerevisiae ATCC 2601. O meio de cultura utilizado foi ágar Sabouraud-dextrose (M4) e este acrescido de 0,7\% de polissorbato 20 e $0,1 \%$ de lecitina de soja (M14), testando-se apenas o volume de $20 \mathrm{~mL}$ por placa.

Após incubação das placas em estufa a $20-25^{\circ} \mathrm{C}$ durante 72 horas, a revelação das colônias foi pela técnica aplicada às bactérias (item 4.2.14), empregando-se o corante a 0,1,0,2, 0,5, 1,0 e 2,0\%, com a diferença de que o revelador havia sido preparado em tampão $\mathrm{pH}$ 7,5 em vez de água destilada.

A observação macroscópica das colônias foi efetuada 1 e 2 horas após adição do reagente, mantendo-se as placas a temperatura ambiente. 


\subsubsection{Determinação da concentração mínima eficaz do cloreto de trifeniltetrazóllo para revelaçăo de colónla de bactérias desenvolvidas em melo com opacidade}

As suspensões de S. aureus, P. aeruginosa, B. subtilis e E. coli com cerca de $50 \mathrm{UFC} / \mathrm{mL}$ foram preparadas conforme técnica descrita no item 4.2.7.

Alíquotas de $1 \mathrm{~mL}$ de cada suspensão e igual volume de suspensão aquosa estéril de hidróxido de alumínio a 6,0\% (R20) foram transferidas para 16 placas de Petri. $O$ meio de cultura empregado foi ágar caseína-soja (M2) em volumes de $15 \mathrm{~mL}$ para 8 réplicas e $20 \mathrm{~mL}$ para o restante das placas.

A sequência do teste, quanto à incubação e aplicação do revelador, foi a mesma descrita no item 4.2.14.

Após a aplicação do reagente na superfície do meio, as placas foram reincubadas em estufa a $33 \pm 1^{\circ} \mathrm{C}$, efetuando-se a contagem das colônias com coloração vermelha a $0,5,1$ e 2 horas.

\subsubsection{Determinação da concentração mínima eficaz do cloreto de trifeniltetrazólio para revelação de colônias de C. albicans desenvolvidas em meio com opacidade}

A suspensão de $C$. albicans, com cerca de $50 \mathrm{UFC} / \mathrm{mL}$, foi preparada conforme a técnica descrita no item 4.2.8.

O mesmo procedimento adotado para bactérias no item 4.2.16 foi aplicado neste caso, empregando-se 4 placas de Petri, com $15 \mathrm{~mL}$ e outros $4 \mathrm{com} 20$ $\mathrm{mL}$ de ágar Sabouraud-dextrose (M4). Este meio, adicionado de $0,7 \%$ de polissorbato 20 e $0,1 \%$ de lecitina de soja (M14) foi testado nas mesmas condições.

A incubação das placas em estufa foi a $20-25^{\circ} \mathrm{C}$ durante 72 horas. 
As concentrações de TTC testadas foram de 0,5, 1,0 e 2,0\% em ágar bacteriológico a 1\% em tampão fosfato pH 7,5 (R17 a R19).

A contagem das colônias, com coloração vermelha, foi efetuada $0,5,1,2$ e 3 horas após aplicação do corante à superfície do meio de cultura, mantendo as placas a temperatura ambiente.

4.2.18 Comparação entre as técnicas de tubos múltiplos com subcultura e de semeadura em profundidade mediante revelação das colônias com cloreto de trifeniltetrazólio em amostras de produtos comerciais, inoculadas com microrganismos padrōes 74,246

Amostras de creme hidratante (C1), suspensão de hidróxido de alumínio (F1) e cremes condicionadores de cabelos (C2 e C3) foram empregadas neste teste.

Estas amostras foram previamente comprovadas quanto à ausência de microrganismos contaminantes através do método estimativo de tubos múltiplos. Para isto, tomadas de $10 \mathrm{~g}$ das amostras semi-sólidas e $10 \mathrm{~mL}$ da suspensão foram diluídas em $90 \mathrm{~mL}$ de solução fisiológica estéril contendo $2,0 \%(p / v)$ de polissorbato 20. O diluente, quando da utilização para os cremes, foi previamemte aquecido para cerca de $45^{\circ} \mathrm{C}$. As amostras C1 e C3 foram mantidas em banho de água a $45 \pm 1^{\circ} \mathrm{C}$, com auxílio de agitação manual até se tornarem dispersões homogêneas.

A partir desta amostra diluída foram efetuadas mais 2 diluições decimais seriadas com $9 \mathrm{~mL}$ do diluente acima empregado.

Alíquotas de $1 \mathrm{~mL}$ de cada diluição da amostra foram transferidas para réplica de 3 tubos contendo $9 \mathrm{~mL}$ de caldo caseína-soja (M1).

Após incubação dos tubos em estufa a $33 \pm 1^{\circ} \mathrm{C}$ durante 48 horas foi efetuada a sub-cultura, semeando-se uma alçada para correspondente número de 
potubos contendo $5 \mathrm{~mL}$ do mesmo meio de cultura (M1)

Após incubação destes tubos por 24 horas em estufa a $33 \pm 1^{\circ} \mathrm{C}$ foi efetuada a observação quanto à presença ou ausência de turvação, cujos dados foram comparados aos da Tabela de NMP ${ }^{74}$.

Seguindo a mesma técnica foram preparadas dispersões das mesmas amostras na proporção de $20 \mathrm{~mL}$ desta para $60 \mathrm{~mL}$ do diluente. Os microrganismos utilizados como contaminantes destas dispersões foram $P$. aeruginosa, $B$. subtilis $\Theta M$. Iuteus, inoculados separadamente. A amostra F1 foi testada frente a estas 3 cepas, enquanto que $C 1$ com $P$. aeruginosa e $B$. subtilis e $C_{2}$ e C3, apenas com $P$. aeruginosa. A diluição da suspensão microbiana foi conforme descrito no item 4.2.7, transferindo-se cerca de $2 \times 10^{3}$ UFC para $80 \mathrm{~mL}$ de cada dispersão. A partir destas, alíquotas de $2 \mathrm{~mL}$ transferidas para réplicas de 10 placas de Petri e homogeneizadas com $15 \mathrm{~mL}$ de ágar caseína-soja (M2).

Após a incubação das placas, em estufa a $33 \pm 1^{\circ} \mathrm{C}$ durante 48 horas, a superfície do meio de cultura de cada placa foi coberta com $5 \mathrm{~mL}$ de ágar bacteriológico a $1 \%$ em água contendo $0,1 \%$ de TTC (R10), preparado conforme descrito no item 4.2.2.

A contagem das colónias vermelhas foi após 1 hora de reincubação das placas em estufa a $33 \pm 1^{\circ} \mathrm{C}$ (Met.4).

A dispersão contaminada, submetida ao teste, foi novamente diluída, transferindo-se $28 \mathrm{~mL}$ para frascos contendo $42 \mathrm{~mL}$ do diluente. Esta segunda diluição igualmente submetida à contagem pela mesma técnica (Met.3), serviu também para efetuar a estimativa da carga viável pela técnica de tubos múltiplos. Para isto, foram efetuadas mais 3 diluições decimais seriadas em solução fisiológica estéril.

De cada diluição, alíquotas de $1 \mathrm{~mL}$ foram transferidas para 30 tubos contendo $9 \mathrm{~mL}$ de caldo caseína-soja (M1). A combinação de 4 diluições com 3 tubos cada consistiu num ensaio, originando total de 10 testes para cada 
microrganismo.

Os tubos foram incubados em estufa a $33 \pm 1^{\circ} \mathrm{C}$ durante 48 horas após o que foram efetuadas observações quanto à presença de turvação e executadas as sub-culturas de todos os tubos, transferindo-se tomada de alçada para $5 \mathrm{~mL}$ do mesmo caldo. A observação da turvação foi após 24 horas de incubação, nas mesmas condições (Met.1).

Após amostragem do conteúdo dos tubos originais para subcultura, para cada um destes foram adicionados $0,5 \mathrm{~mL}$ de solução aquosa de TTC a $1 \%$ (R3) e reincubados nas mesmas condições, durante 1 hora (Met.2).

A combinação do número de tubos positivos, em função do parâmetro de turvação ou coloração serviu para a determinação da estimativa de carga contaminante após o confronto com a Tabela de NMP ${ }^{74}$.

\subsubsection{Avaliação da eficiência do cloreto de trifeniltetrazólio aplicado ao método de tubos múltiplos e semeadura em profundidade para determinação de carga microbiana contaminante em amostras comercializadas 74,246}

Foram envolvidas neste ensaio as amostras F2, F3, F4, F5 e F6, C4, C5 e C6, adquiridas no comércio, conforme descritas no item 4.1.3.

Estas foram previamente analisadas quanto à carga microbiana contaminante, pelo método estimativo de tubos múltiplos, conforme descrito no item 4.2.11, empregando-se o caldo caseína-soja e como recurso para detecção do crescimento, a sub-cultura.

Amostras que não apresentaram carga microbiana viável foram excluídas deste experimento. Aquelas com número mais provável (NMP) maior que $10^{3} / \mathrm{g}(\mathrm{mL})$ foram retestadas pelo método de semeadura em profundidade. Para isto, foram testadas as diluições de $10^{-1}$ a $10^{-4}$, utilizando solução fisiológica estéril como 
diluente, usando como primeira dispersão aquela da técnica de tubo múltiplos. De cada diluição, alíquotas de $1 \mathrm{~mL}$, em duplicatas, foram homogeneizadas com cerca de $15 \mathrm{~mL}$ de meio de ágar caseína-soja (M2).

Após incubação das placas, por 72 horas, em estufa a $33 \pm 1^{\circ} \mathrm{C}$ foi efetuada a contagem do número de colônias, empregando-se o contador de colônias Quebec $^{R}$. O número de unidades formadoras de colônias por grama ou mililitro (UFC/g ou $\mathrm{mL}$ ) de amostra foi determinado a partir das placas com 30 a 300 colônias.

Para o ensaio com o TTC, amostras com carga contaminante original superior a $10^{2} / \mathrm{g}(\mathrm{mL})$ foram ajustadas após a esterilização, de modo que a diluição inicial apresentasse número de viáveis correspondente a $10^{2} \mathrm{UFC} / \mathrm{g}(\mathrm{mL})$ do produto como tal. Para isto, $20 \mathrm{~g}(\mathrm{~mL})$ da amostra foram diluídos com $60 \mathrm{~mL}$ de solução fisiológica estéril adicionada de $2 \%(p / v)$ de polissorbato 20 . Esta dispersão foi submetida à esterilização em autoclava, à $121^{\circ} \mathrm{C}$, durante 15 minutos e reinoculados com a mesma amostra, diluída com o mesmo diluente, de modo que contivesse cerca de $2 \times 10^{3} \mathrm{UFC} / \mathrm{mL}$, transferindo-se alíquota de $1 \mathrm{~mL}$.

O prosseguimento do ensaio foi exatamente igual àquele executado no teste anterior (item 4.2.18), correspondente aos produtos inoculados com microrganismos padrões.

\subsubsection{Análise estatística dos resultados 221}

A análise estatística foi efetuada para os dados obtidos nos dois últimos testes.

A comparação entre os métodos, dentro de cada amostra, foi através do teste de Kruskal-Walis, cuja estatística foi denotada por $\mathrm{H}$. 
Para a análise da variabilidade ou precisão dos métodos dois a dois, dentro de cada amostra, foi utilizado o teste de Siegel-Tukey unilateral.

O teste de Friedman foi aplicado para comparação dos coeficientes de variação entre os métodos.

O nível de significância adotado foi de $5 \%(\alpha=0,05)$ 


\section{RESULTADOS}

Os dados referentes à concentração mínima inibitória (MIC) do cloreto de trifeniltetrazólio frente a $S$. aureus, M. luteus, M. Flavus, B. subtilis, B. pumilus, $P$. aeruginosa e $E$. coli constam nas Tabelas II a IV.

A comparação das intensidades de coloração nas diferentes combinações de meio e concentração de TTC para suspensões de $S$. aureus, $P$. aeruginosa, S. epidermidis, $M$. flavus, $M$. luteus e $B$. subtilis, com inóculo de $10^{8}$ UFC/mL, após incubação de 1, 2 e 4 horas, encontra-se nas Tabelas $V$ a X. Os dados do mesmo ensaio referentes ao ináculo de $10^{7} \mathrm{UFC} / \mathrm{mL}$, após incubação de 4 horas, constam nas Tabelas XI e XII. Pela diminuição do inóculo de S. aureus e $P$. aeruginosa não houve desenvolvimento da coloração macroscopicamente visível com até 4 horas de incubação; os dados referentes à incubação de 20 horas constam nas Tabelas XIII e XIV.

Os dados referentes à comparação entre as técnicas de tubos múltiplos com sub-cultura e de redução de TTC encontram-se nas Tabelas XV a XXII e XXIV a XXVII, sendo que de XV a XVIII se referem a $S$. aureus, S. epidermidis, $M$. luteus, M. flavus, B. subtilis, $B$. pumilus, $P$. aeruginosa e $E$. coli e XXIV e XXV, aos inóculos de C. albicans e S. cerevisiae, todos frente à concentração de $500 \mu \mathrm{g} / \mathrm{mL}$ de TTC. Os dados do mesmo ensaio,com $1.000 \mu \mathrm{g} / \mathrm{mL}$ do corante, configuram nas Tabelas XIX a XXII para as bactérias e XXVI e XXVII para as leveduras. Os dados referentes ao mesmo ensaio, realizado para $C$. albicans em meio de cultura alcalinizado encontramse na Tabela $X X X$.

A tabela XXIII refere-se ao número total de tubos com resposta positiva decorrentes dos dados das Tabelas XV a XXII. Nas tabelas XXVIII e XXIX constam os dados resultantes, respectivamente, das Tabelas XXIV e XXVI e das XXV e XXVII.

Os dados referentes à determinação da concentração mínima 
eficaz de TTC para coloração de colónias de bactérias desenvolvidas por semeadura em profundidade constam na Tabela XXXII; os dados, correspondentes às leveduras configuram nas Tabelas XXXIII e XXXIV, em função do gel preparado em água ou em tampão fosfato $\mathrm{pH} 7,5$.

Nas tabelas XXXV e XXXYI constam os dados relativos à determinação de concentração mínima eficaz de TTC para revelação de colônias, respectivamente, para bactérias e leveduras, em meio com opacidade.

$\mathrm{Na}$ tabela $X X X I$ configuram os dados da avaliação da atividade inibitória do polissorbato 20 e 80 e da lecitina de soja frente a S. aureus, S. epidermidis e M. luteus.

Os dados referentes a carga viável de microrganismos padrões em produtos comercializados determinados, pelas técnicas de tubos múltiplos e semeadura em profundidade, após revelação com TTC ou sub-cultura constam na Tabela XXXVII. Na Tabela XLl encontram-se os dados relativos aos microrganismos contaminantes.

A comparação dos dados de contagem em amostras com microrganismos padrões, entre os métodos de tubos múltiplos e semeadura em profundidade dentro de cada amostra consta na Tabela XXXVIII. O mesmo teste aplicado às amostras do mercado contaminadas consta na Tabela XLIII.

As medidas de variabilidade descritivas estão nas Tabelas XXXIX e XLIV.

A comparação das variabilidades entre o método de tubos múltiplos em relação à semeadura em profundidade consta nas Tabelas XL e XLV.

Nas Tabelas XLI e XLVI estão configurados os valores de comparação dos coeficientes de variação dos 3 métodos obtidos respectivamente a partir de amostras com microrganismos padrões e naturalmente contaminadas. 
TABELA II. Determinação da Concentração mínima Inibitória do TTC em meio líquido frente a 3 inóculos de diversos microrganismos.

\begin{tabular}{|c|c|c|c|c|c|c|c|}
\hline \multirow{2}{*}{$\begin{array}{l}\text { Microorga- } \\
\text { nismo }\end{array}$} & \multirow{2}{*}{$\begin{array}{l}\text { Inóculo } \\
\text { (UFC/Tubo) }\end{array}$} & \multicolumn{4}{|c|}{$\pi \mathrm{TC}(\mu \mathrm{g} / \mathrm{mL})$} & \multirow{2}{*}{$\begin{array}{l}\text { Intensi- } \\
\text { dade de } \\
\text { turvação }\end{array}$} & \multirow{2}{*}{ Coloração ${ }^{b}$} \\
\hline & & 0 & 30 & 60 & 120 & & \\
\hline S. aureus & $10^{3}$ & $x$ & $x$ & $x$ & $x$ & $\begin{array}{l}3(3+) \\
3(3+) \\
3(2+) \\
3(2+)\end{array}$ & $\begin{array}{l}3(-) \\
3(+) \\
3(+) \\
3(+)\end{array}$ \\
\hline & $10^{2}$ & $x$ & $x$ & $x$ & $x$ & $\begin{array}{l}3(3+) \\
3(2+) \\
3(+) \\
3(+)\end{array}$ & $\begin{array}{l}3(-) \\
3(-) \\
3(-) \\
3(-)\end{array}$ \\
\hline & 10 & $x$ & $x$ & $x$ & $x$ & $\begin{array}{l}3(3+) \\
3(+) \\
3(+) \\
3(+)\end{array}$ & $\begin{array}{l}3(-) \\
3(-) \\
3(-) \\
3(-)\end{array}$ \\
\hline M. flavus & $10^{3}$ & $x$ & $x$ & $x$ & $x$ & $\begin{array}{l}3(3+) \\
3(-) \\
3(-) \\
3(-)\end{array}$ & $\begin{array}{l}3(-) \\
3(-) \\
3(-) \\
3(-)\end{array}$ \\
\hline & $10^{2}$ & $x$ & $x$ & $x$ & $x$ & $\begin{array}{l}3(2+) \\
3(-) \\
3(-) \\
3(-)\end{array}$ & $\begin{array}{l}3(-) \\
3(-) \\
3(-) \\
3(-)\end{array}$ \\
\hline & 10 & $x$ & $x$ & $x$ & $x$ & $\begin{array}{l}3(+) \\
3(-) \\
3(-) \\
3(-)\end{array}$ & $\begin{array}{l}3(-) \\
3(-) \\
3(-) \\
3(-)\end{array}$ \\
\hline M. Iuteus & $10^{3}$ & $x$ & $x$ & $x$ & $x$ & $\begin{array}{l}3(3+) \\
3(-) \\
3(-) \\
3(-)\end{array}$ & $\begin{array}{l}3(-) \\
3(-) \\
3(-) \\
3(-)\end{array}$ \\
\hline & $10^{2}$ & $x$ & $x$ & $x$ & $x$ & $\begin{array}{l}3(3+) \\
3(-) \\
3(-) \\
3(-)\end{array}$ & $\begin{array}{l}3(-) \\
3(-) \\
3(-) \\
3(-)\end{array}$ \\
\hline & 10 & $x$ & $x$ & $x$ & $x$ & $\begin{array}{l}3(3+) \\
3(-) \\
3(-) \\
3(-)\end{array}$ & $\begin{array}{l}3(-) \\
3(-) \\
3(-) \\
3(-)\end{array}$ \\
\hline
\end{tabular}

(-) Sem turvação ou coloração

a) número de tubos com resposta positiva, comparada para cada espécie, considerando $(+)$ como a menor turvação macroscopicamente detectável.

b) número de tubos com resposta positiva, comparada para cada espécie, considerando $(+)$ como a menor coloração macroscopicamente detectável. 
TABELA III. Determinação da Concentração mínima inibitória do TTC em meio líquido frente a 3 inóculos de diversos microrganismos.

\begin{tabular}{|c|c|c|c|c|c|c|c|}
\hline \multirow{2}{*}{$\begin{array}{l}\text { Microorga- } \\
\text { nismo }\end{array}$} & \multirow{2}{*}{$\begin{array}{l}\text { Inóculo } \\
\text { (UFC/Tubo) }\end{array}$} & \multicolumn{4}{|c|}{ TTC $(\mu \mathrm{g} / \mathrm{mL})$} & \multirow{2}{*}{$\begin{array}{l}\text { Intensi- } \\
\text { dade de } \\
\text { turvaçãoa }\end{array}$} & \multirow{2}{*}{$\begin{array}{l}\text { Colora- } \\
\text { çãob }\end{array}$} \\
\hline & & 0 & 30 & 60 & 120 & & \\
\hline \multirow[t]{3}{*}{ B. subtilis } & $10^{3}$ & $x$ & $x$ & $x$ & $x$ & $\begin{array}{l}3(3+) \\
3(+) \\
3(+) \\
3(+)\end{array}$ & $\begin{array}{l}3(-) \\
3(-) \\
3(-) \\
3(-)\end{array}$ \\
\hline & $10^{2}$ & $x$ & $x$ & $x$ & $x$ & $\begin{array}{l}3(3+) \\
3(+) \\
3(+) \\
3(+)\end{array}$ & $\begin{array}{l}3(-) \\
3(-) \\
3(-) \\
3(-)\end{array}$ \\
\hline & 10 & $x$ & $x$ & $x$ & $x$ & $\begin{array}{l}3(3+) \\
3(+) \\
3(+) \\
3(+)\end{array}$ & $\begin{array}{l}3(-) \\
3(-) \\
3(-) \\
3(-)\end{array}$ \\
\hline \multirow[t]{3}{*}{ B. pumilus } & $10^{3}$ & $x$ & $x$ & $x$ & $x$ & $\begin{array}{l}3(2+) \\
3(+) \\
3(+) \\
3(+)\end{array}$ & $\begin{array}{l}3(-) \\
3(-) \\
3(-) \\
3(-)\end{array}$ \\
\hline & $10^{2}$ & $x$ & $x$ & $x$ & $x$ & $\begin{array}{l}3(2+) \\
3(+) \\
3(+) \\
3(+)\end{array}$ & $\begin{array}{l}3(-) \\
3(-) \\
3(-) \\
3(-)\end{array}$ \\
\hline & 10 & $x$ & $x$ & $x$ & $x$ & $\begin{array}{l}3(2+) \\
3(+) \\
3(+) \\
3(+)\end{array}$ & $\begin{array}{l}3(-) \\
3(-) \\
3(-) \\
3(-)\end{array}$ \\
\hline
\end{tabular}

(-) sem turvação ou coloração

a) número de tubos com resposta positiva, comparada para cada espécie, considerando (+) como a menor turvação macroscopicamente detectável.

b) número de tubos com resposta positiva, comparada para cada espécie, considerando (+) como a menor coloraçāo macroscopicamente detectável. 
TABELA IV. Determinação da Concentração mínima inibitória do TTC em meio líquido frente a 3 inóculos de diversos microrganismos.

\begin{tabular}{|c|c|c|c|c|c|c|c|}
\hline \multirow{2}{*}{$\begin{array}{l}\text { Microorga- } \\
\text { nismo }\end{array}$} & \multirow{2}{*}{$\begin{array}{l}\text { Inóculo } \\
\text { (UFC/Tubo) }\end{array}$} & \multicolumn{4}{|c|}{$\pi \mathrm{TC}(\mu \mathrm{g} / \mathrm{mL})$} & \multirow{2}{*}{$\begin{array}{l}\text { Intensi- } \\
\text { dade de } \\
\text { turvaçãoa }\end{array}$} & \multirow{2}{*}{$\begin{array}{l}\text { Colora- } \\
\text { çāob }\end{array}$} \\
\hline & & 0 & 30 & 60 & 120 & & \\
\hline \multirow[t]{3}{*}{$P$. aeruginosa } & $10^{3}$ & $x$ & $\mathrm{x}$ & $x$ & $x$ & $\begin{array}{l}3(3+) \\
3(3+) \\
3(3+) \\
3(3+)\end{array}$ & $\begin{array}{l}3(-) \\
3(+) \\
3(+) \\
3(+)\end{array}$ \\
\hline & $10^{2}$ & $x$ & $\mathrm{x}$ & $x$ & $x$ & $\begin{array}{l}3(+) \\
3(+) \\
3(+) \\
3(+)\end{array}$ & $\begin{array}{l}3(-) \\
3(+) \\
3(+) \\
3(+)\end{array}$ \\
\hline & 10 & $x$ & $x$ & $x$ & $x$ & $\begin{array}{l}3(t) \\
3(t) \\
3(t) \\
3(t)\end{array}$ & $\begin{array}{l}3(-) \\
3(+) \\
3(+) \\
3(+)\end{array}$ \\
\hline \multirow[t]{3}{*}{ E. coli } & $10^{3}$ & $x$ & $x$ & $x$ & $x$ & $\begin{array}{l}3(3+) \\
3(3+) \\
3(3+) \\
3(3+)\end{array}$ & $\begin{array}{l}3(-) \\
3(+) \\
3(+) \\
3(+)\end{array}$ \\
\hline & $10^{2}$ & $x$ & $x$ & $x$ & $x$ & $\begin{array}{l}3(3+) \\
3(3+) \\
3(3+) \\
3(3+)\end{array}$ & $\begin{array}{l}3(-) \\
3(+) \\
3(+) \\
3(+)\end{array}$ \\
\hline & 10 & $x$ & $x$ & $x$ & $x$ & $\begin{array}{l}3(3+) \\
3(3+) \\
3(3+) \\
3(3+)\end{array}$ & $\begin{array}{l}3(-) \\
3(-) \\
3(+) \\
3(+)\end{array}$ \\
\hline
\end{tabular}

(-) sem turvação ou coloração

a) número de tubos com resposta positiva, comparada para cada espécie, considerando (+) como a menor turvação macroscopicamente detectável.

b) número de tubos com resposta positiva, comparada para cada espécie, considerando (+) como a menor coloraçāo macroscopicamente detectável. 


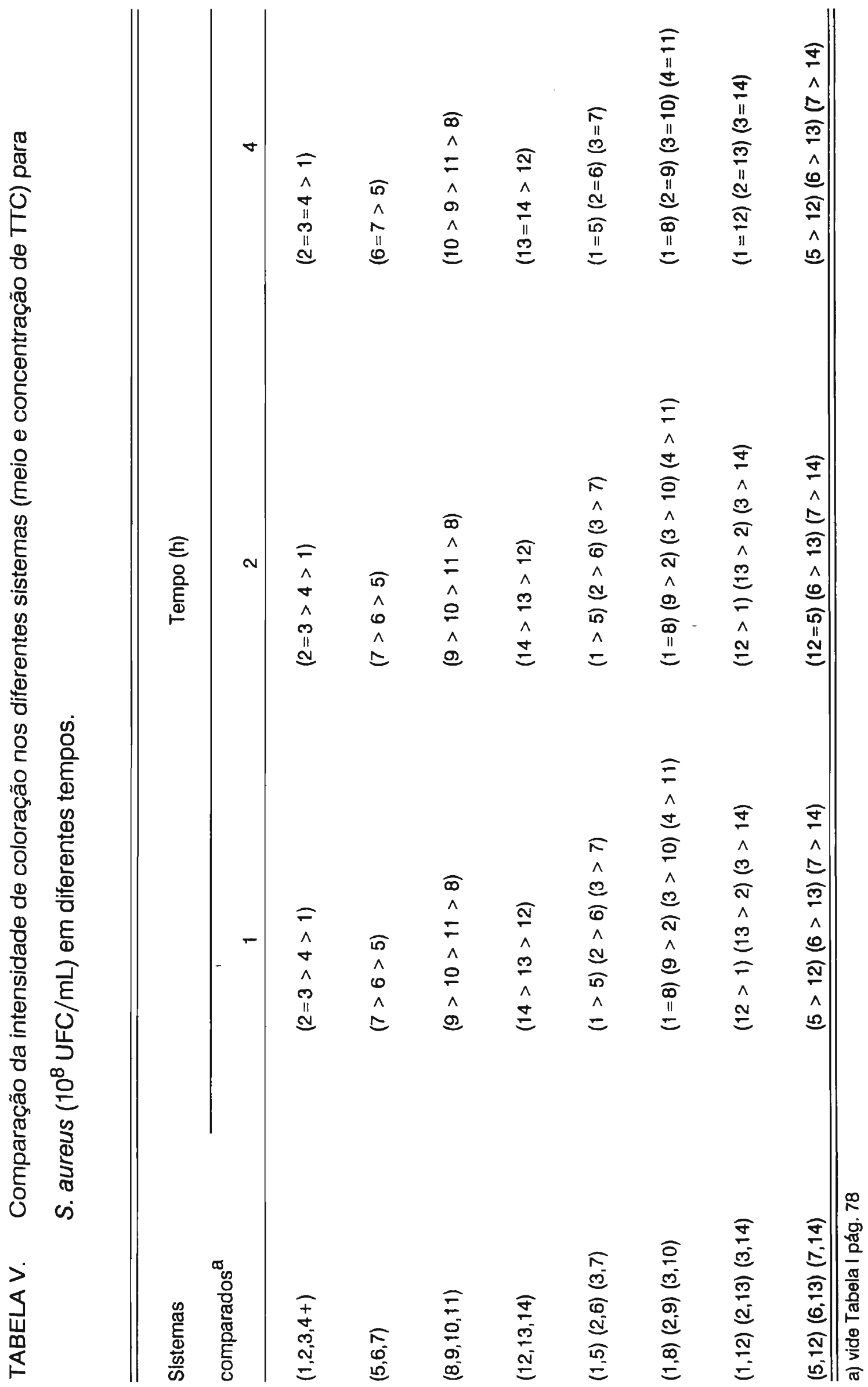




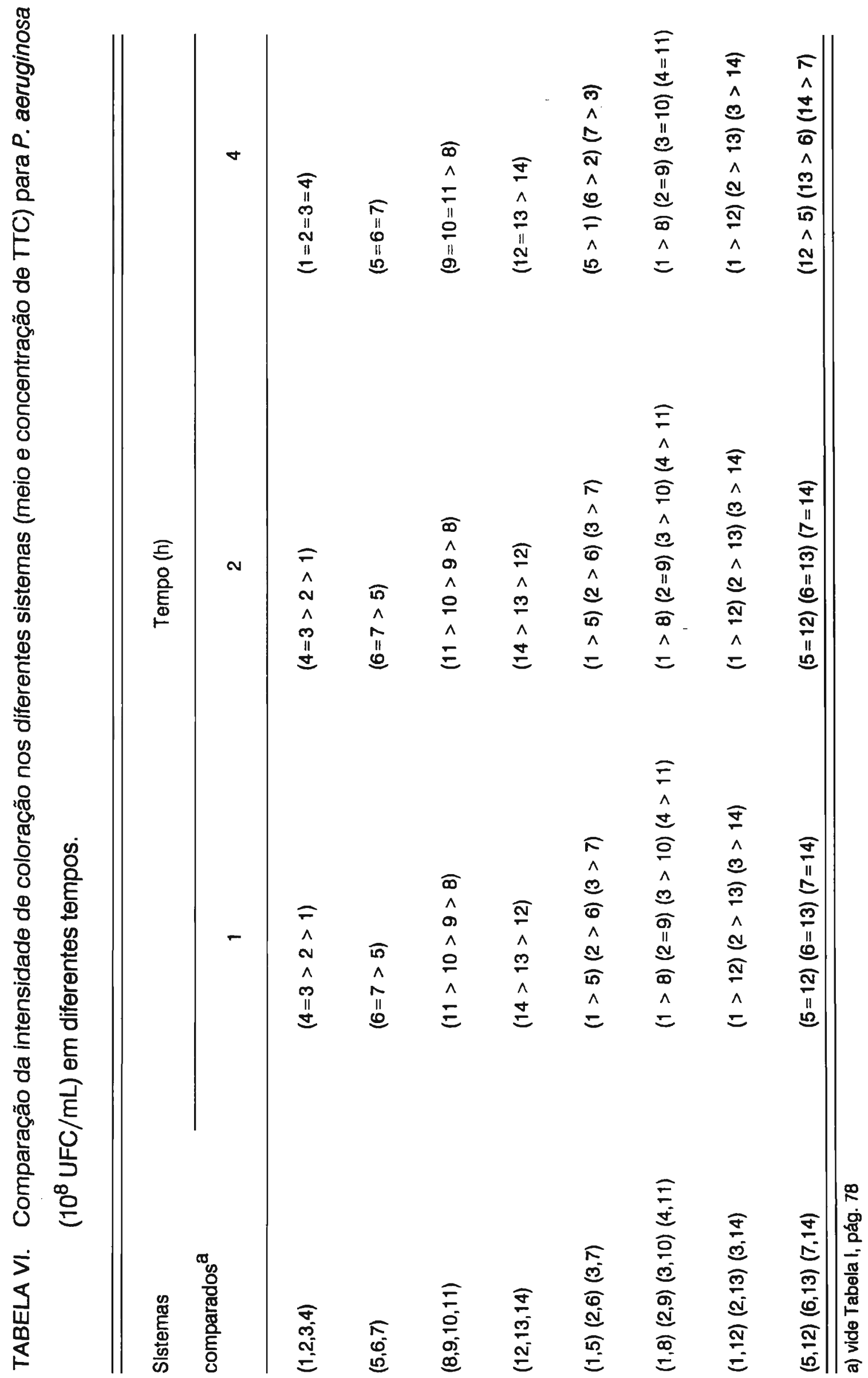




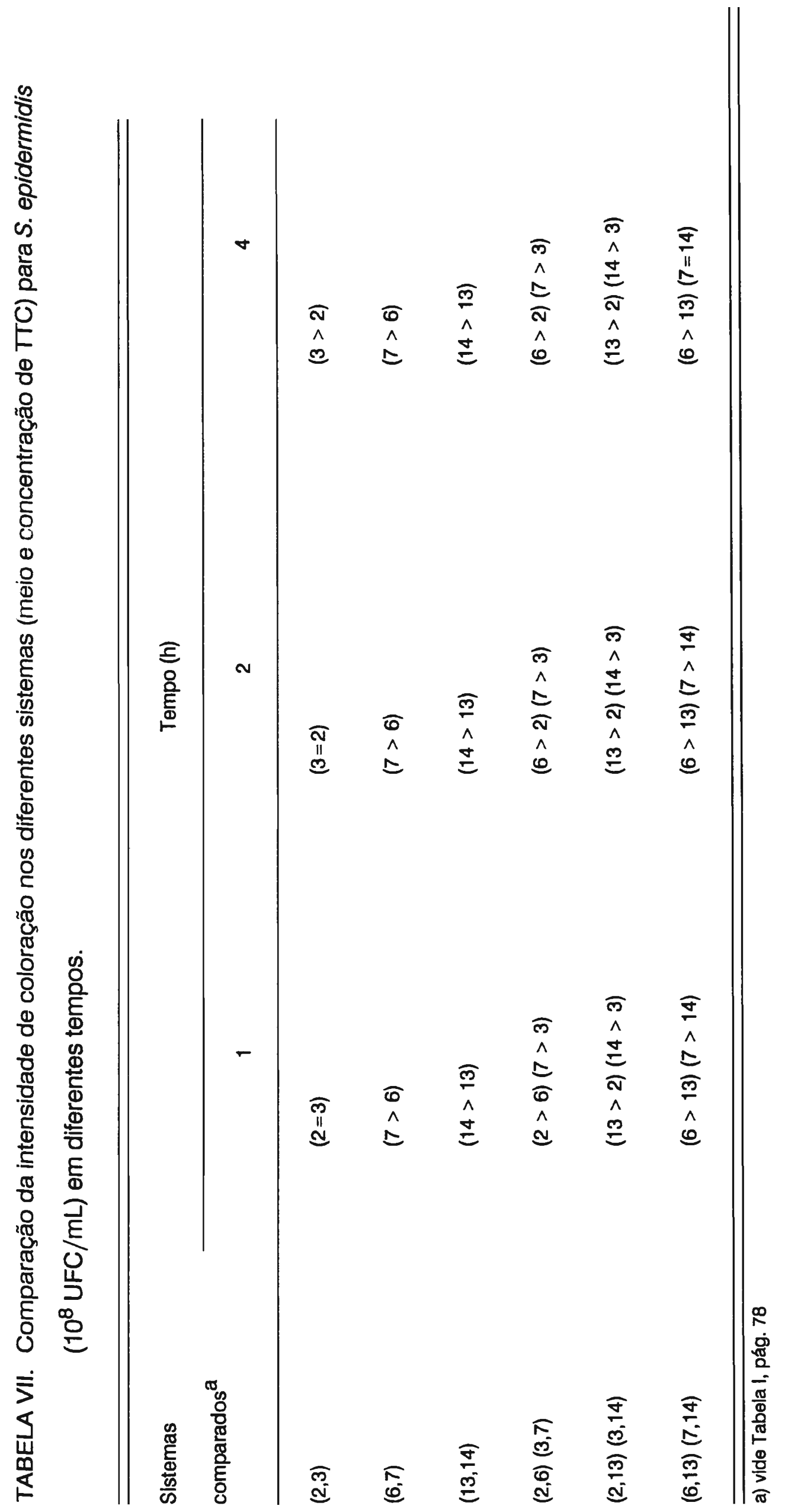




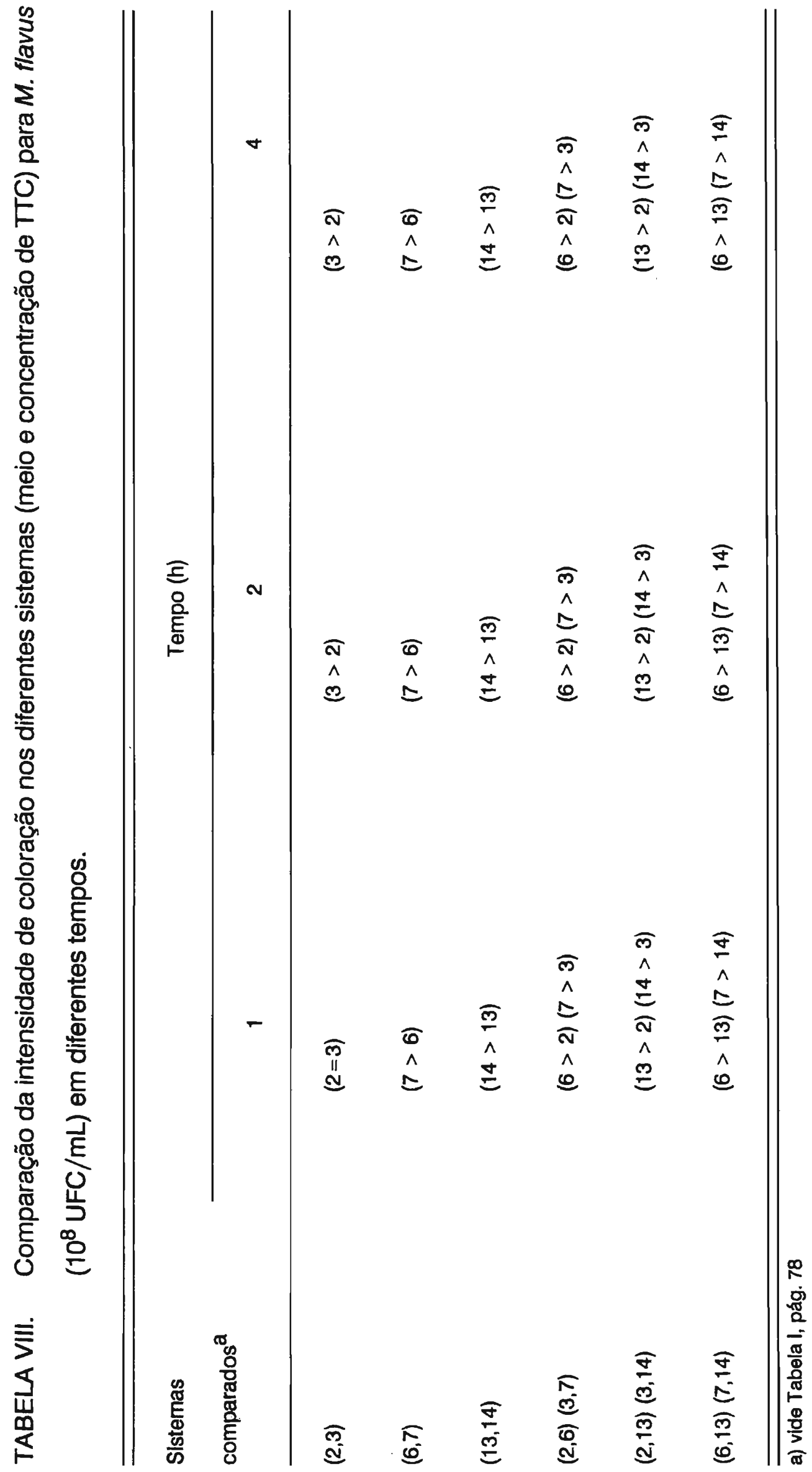




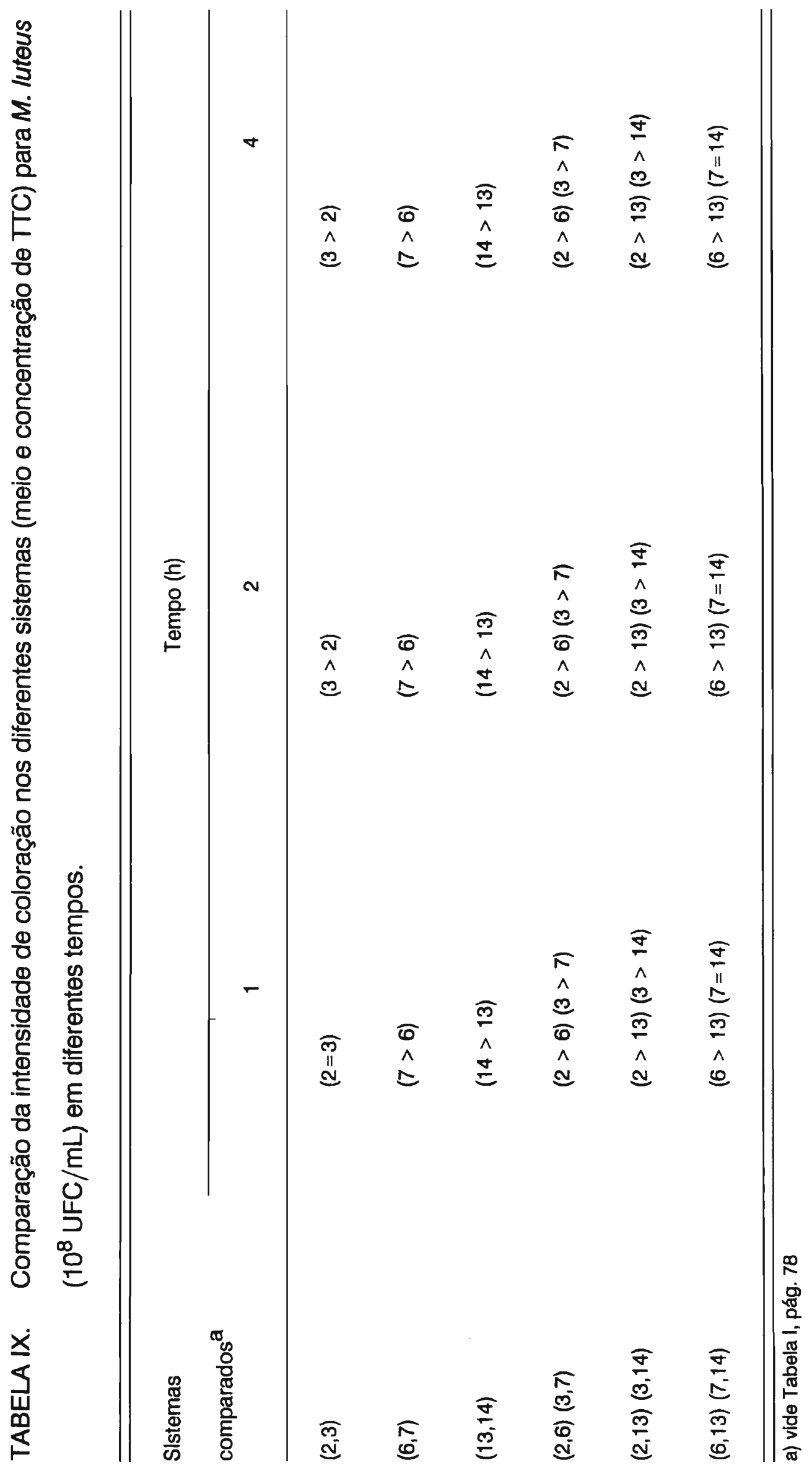




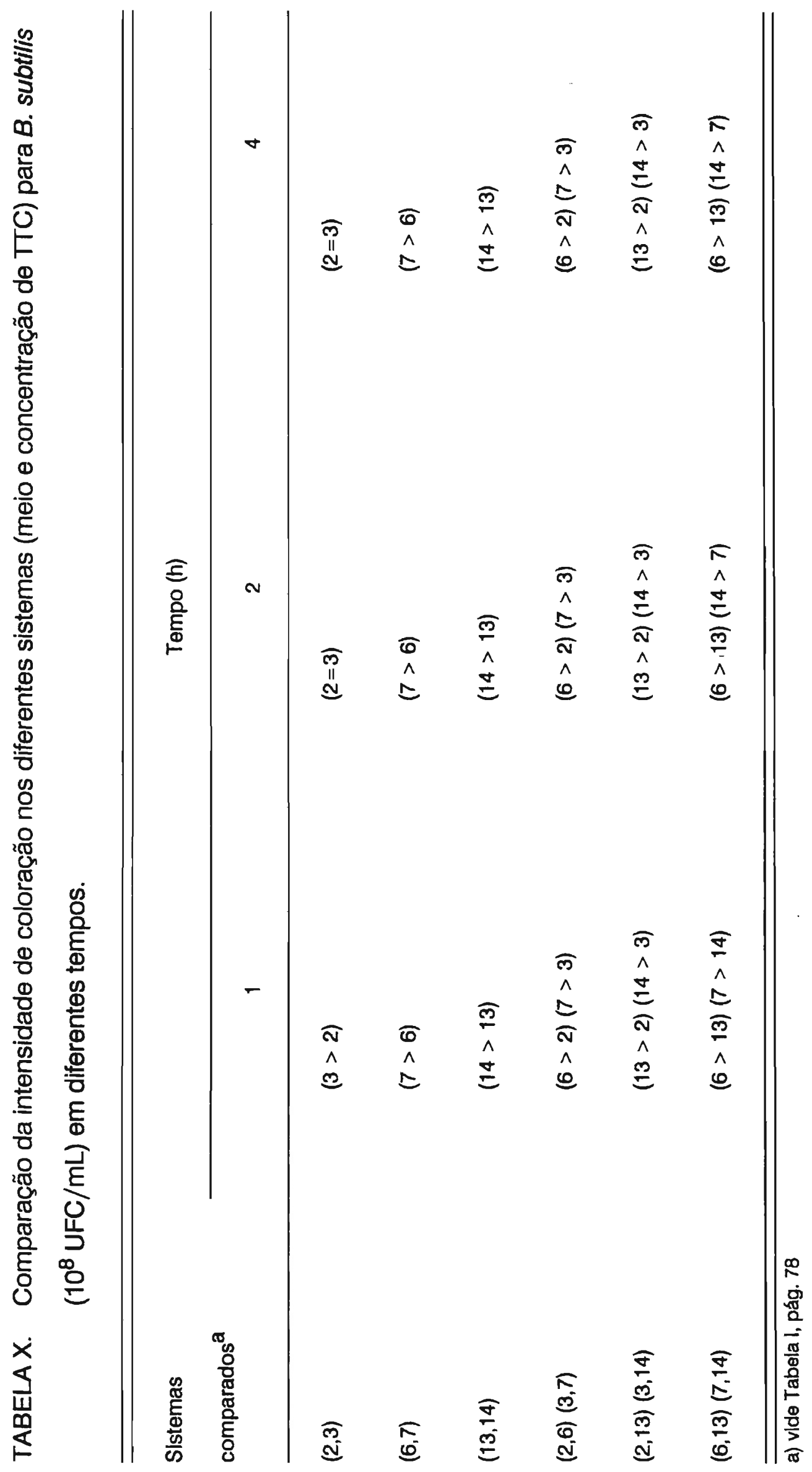




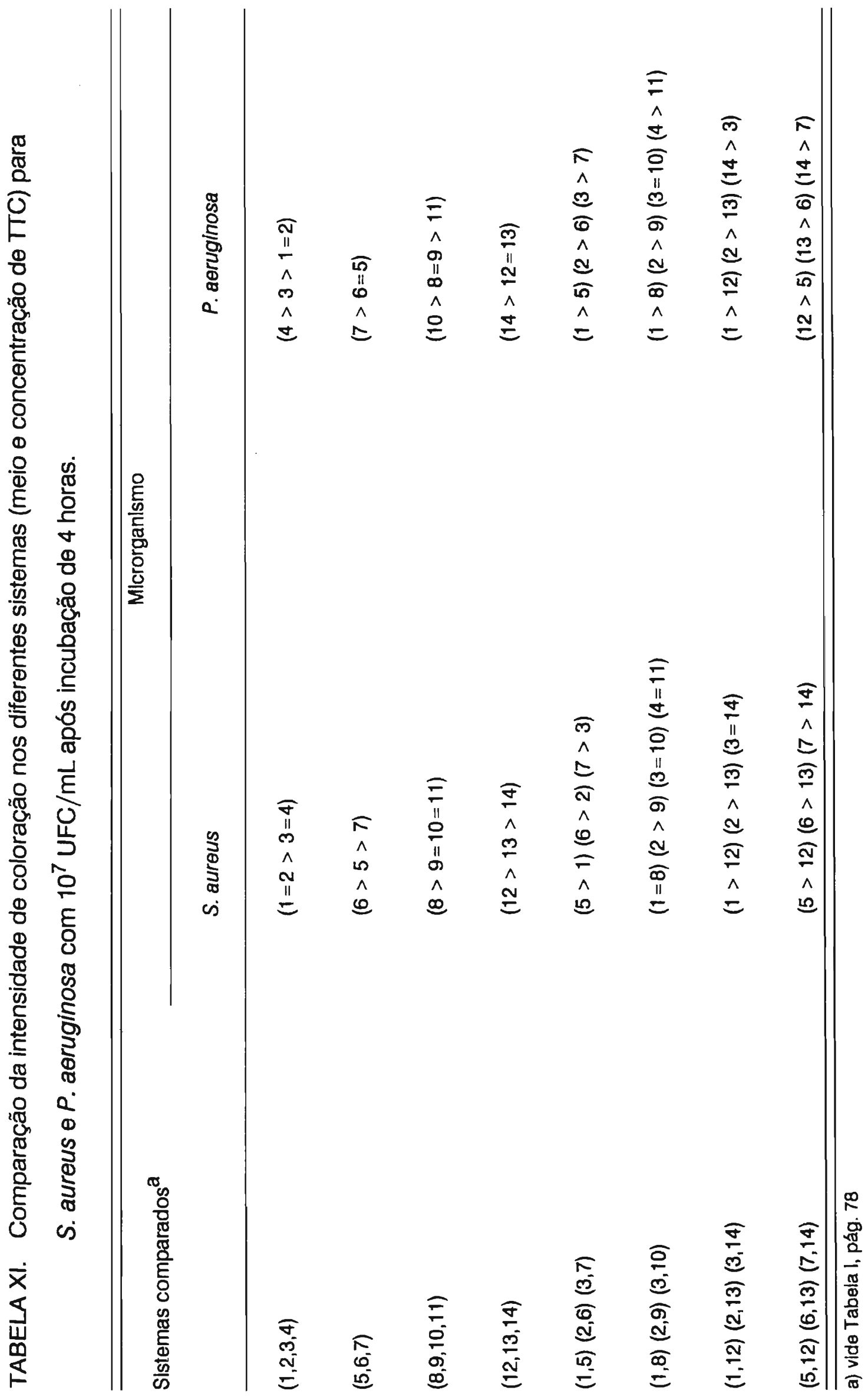




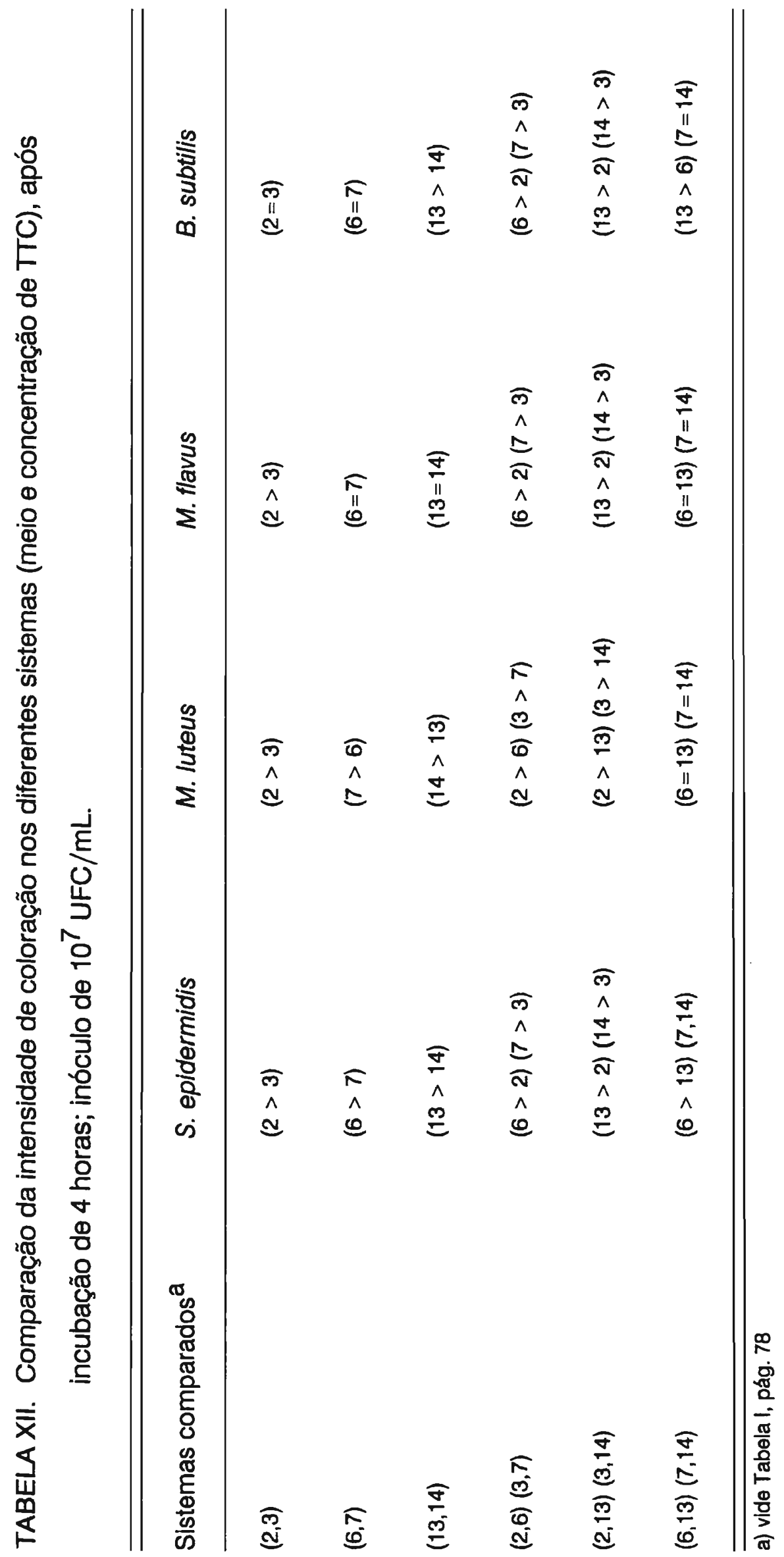




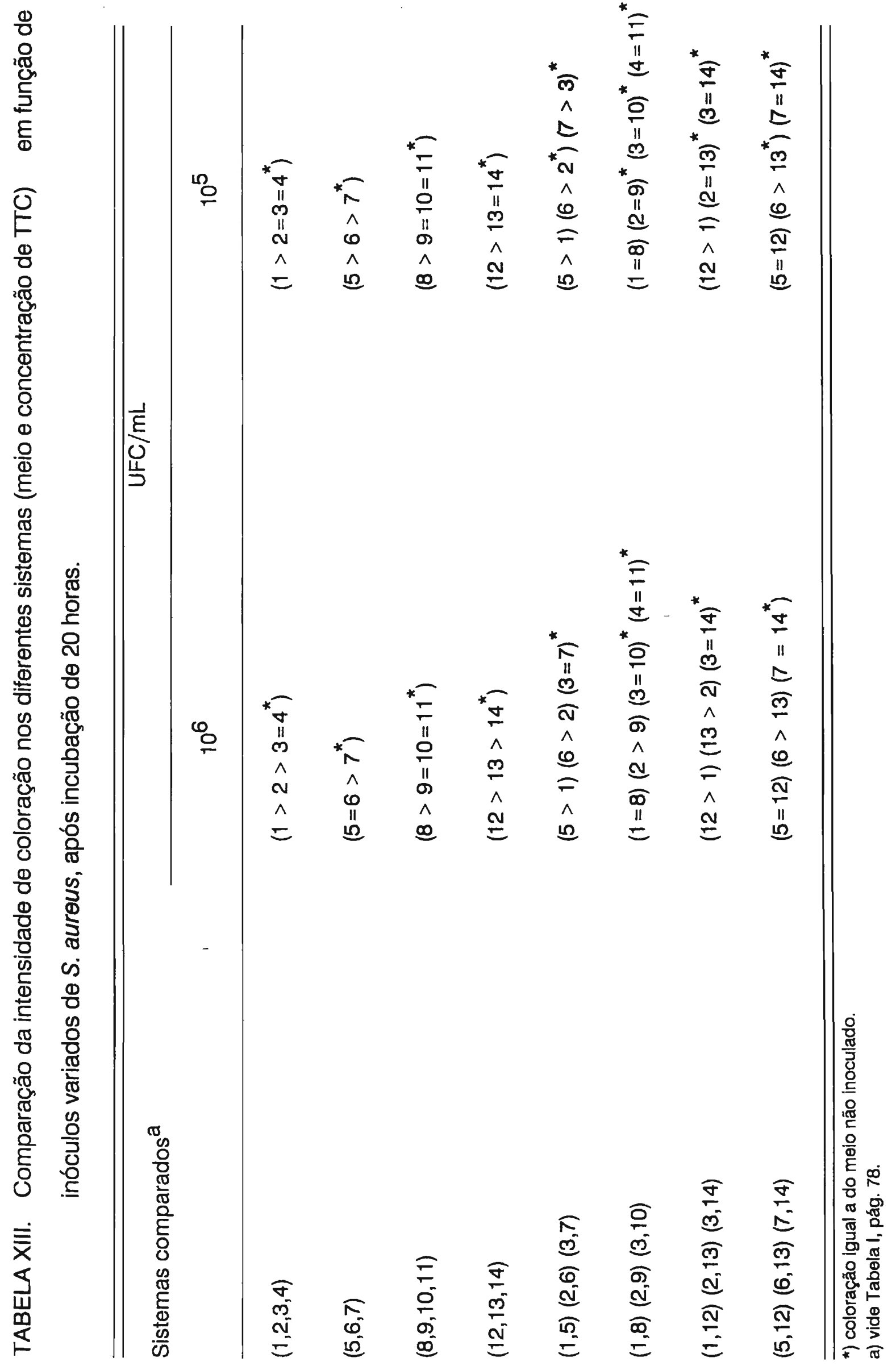




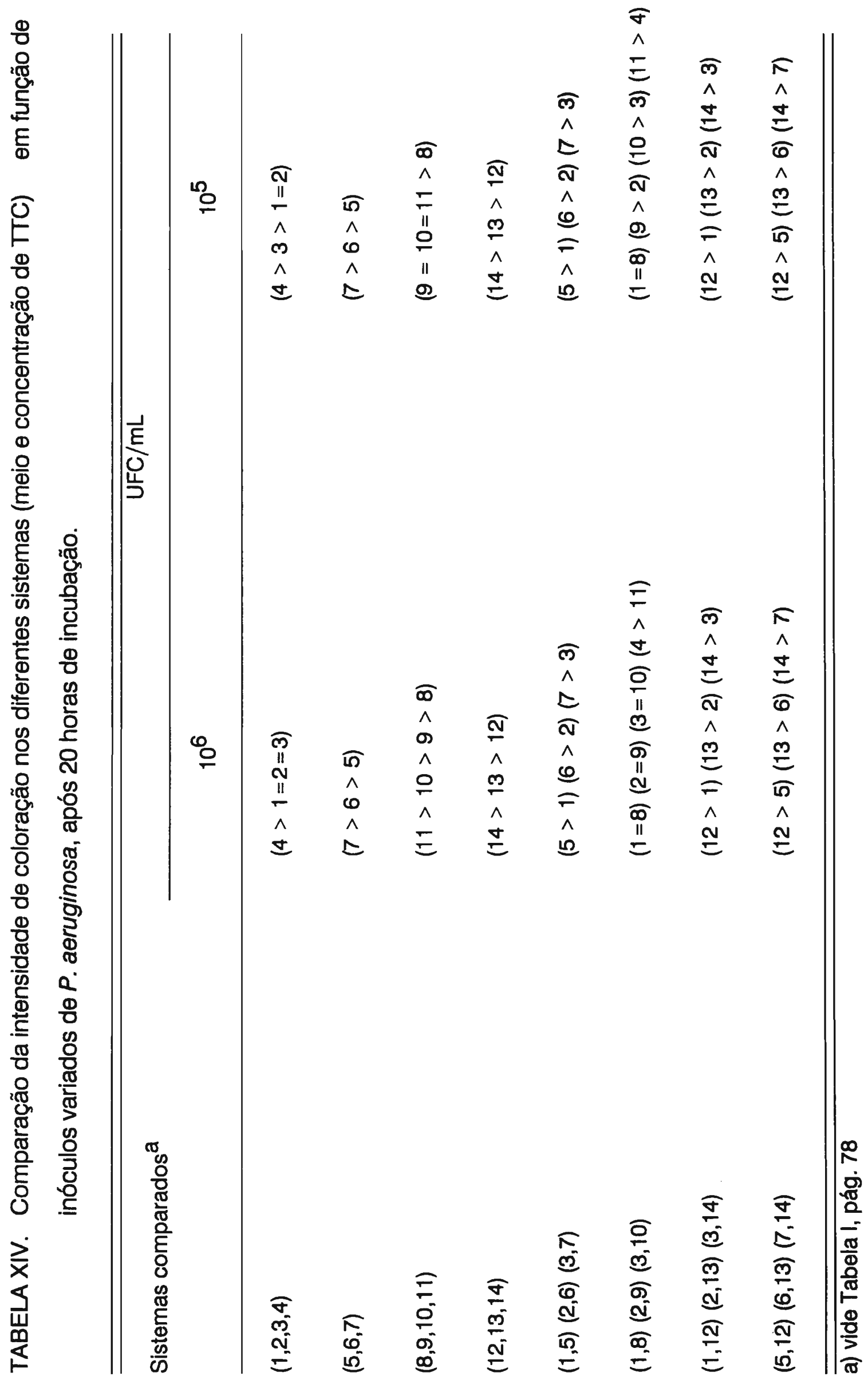




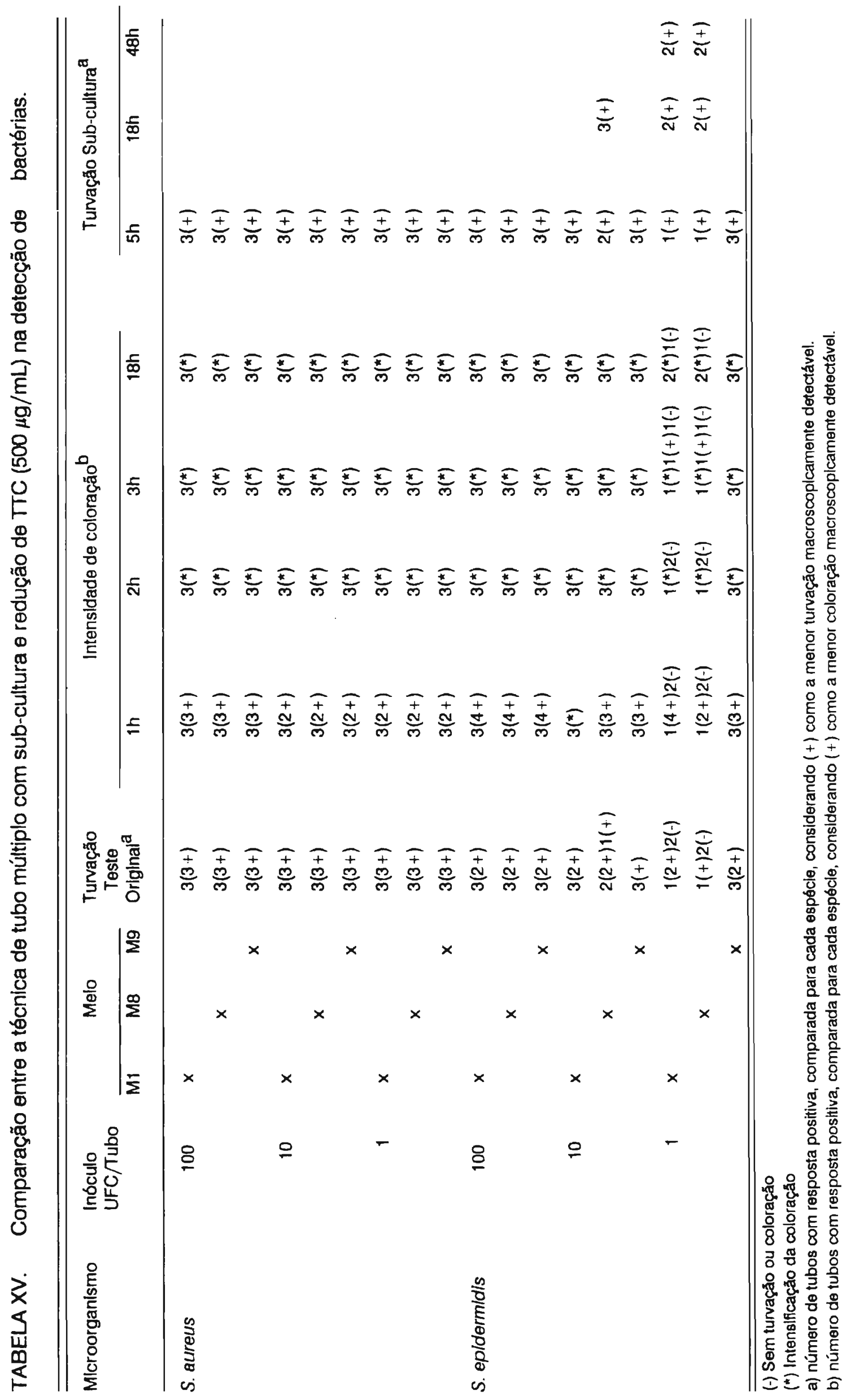




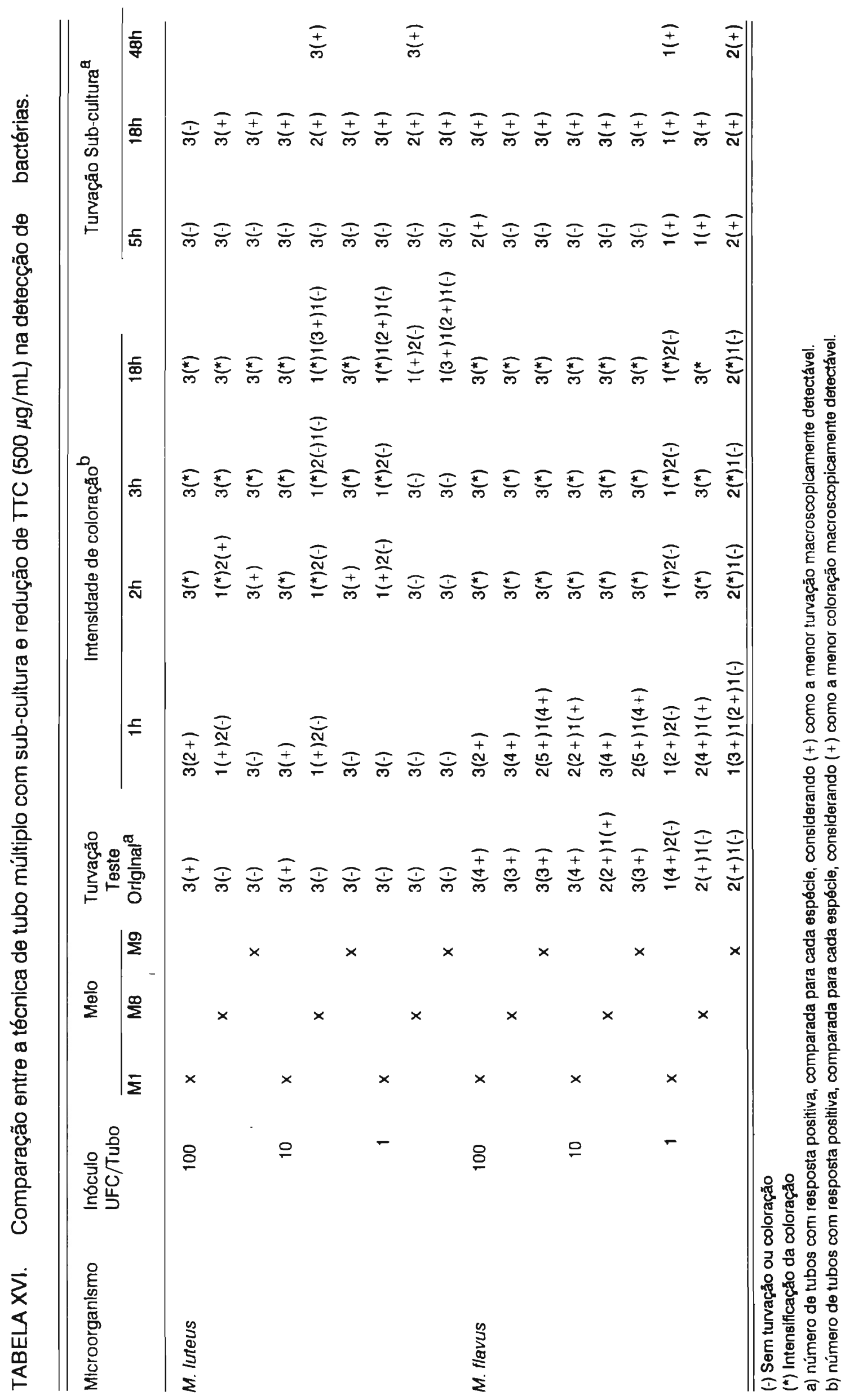




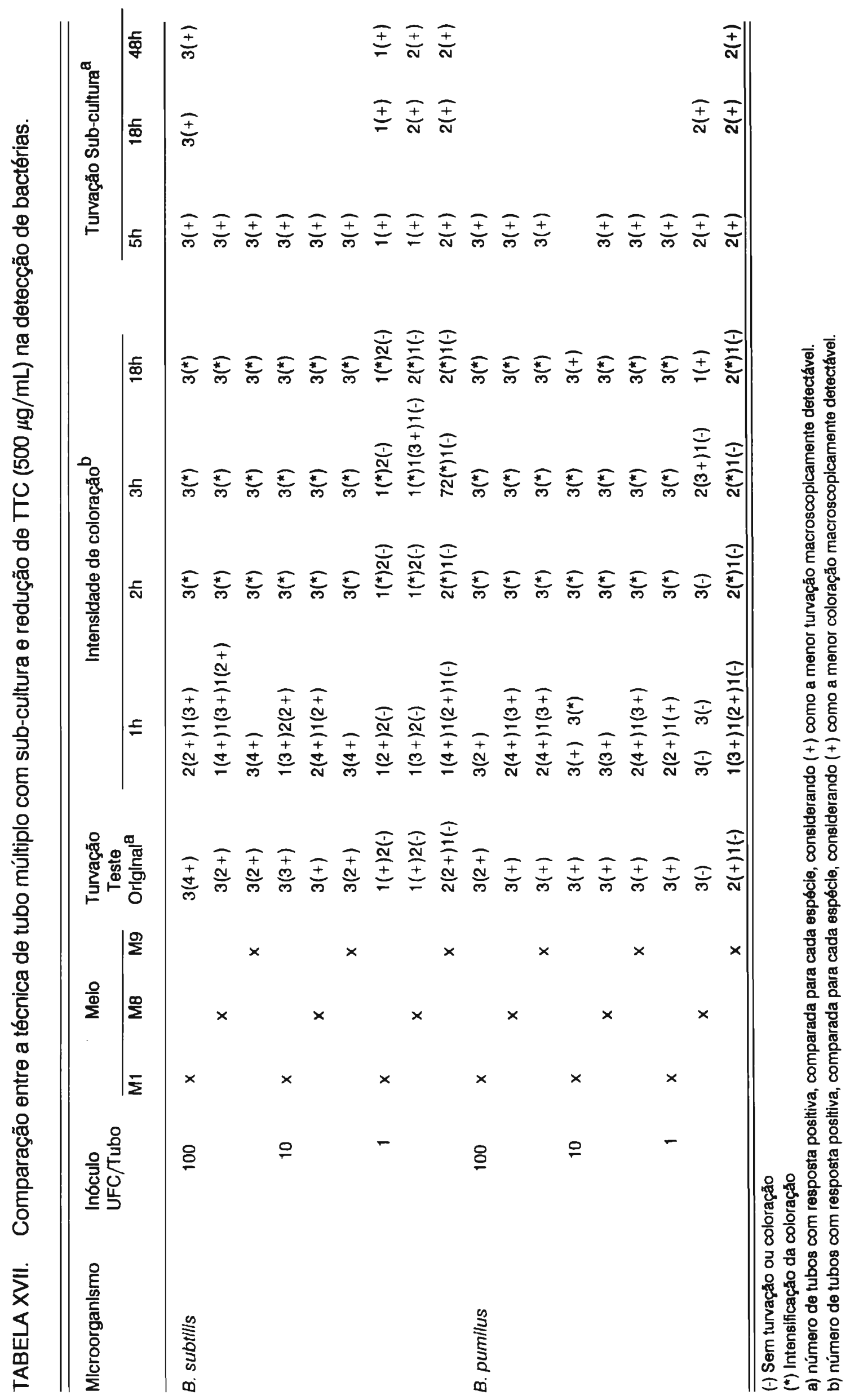




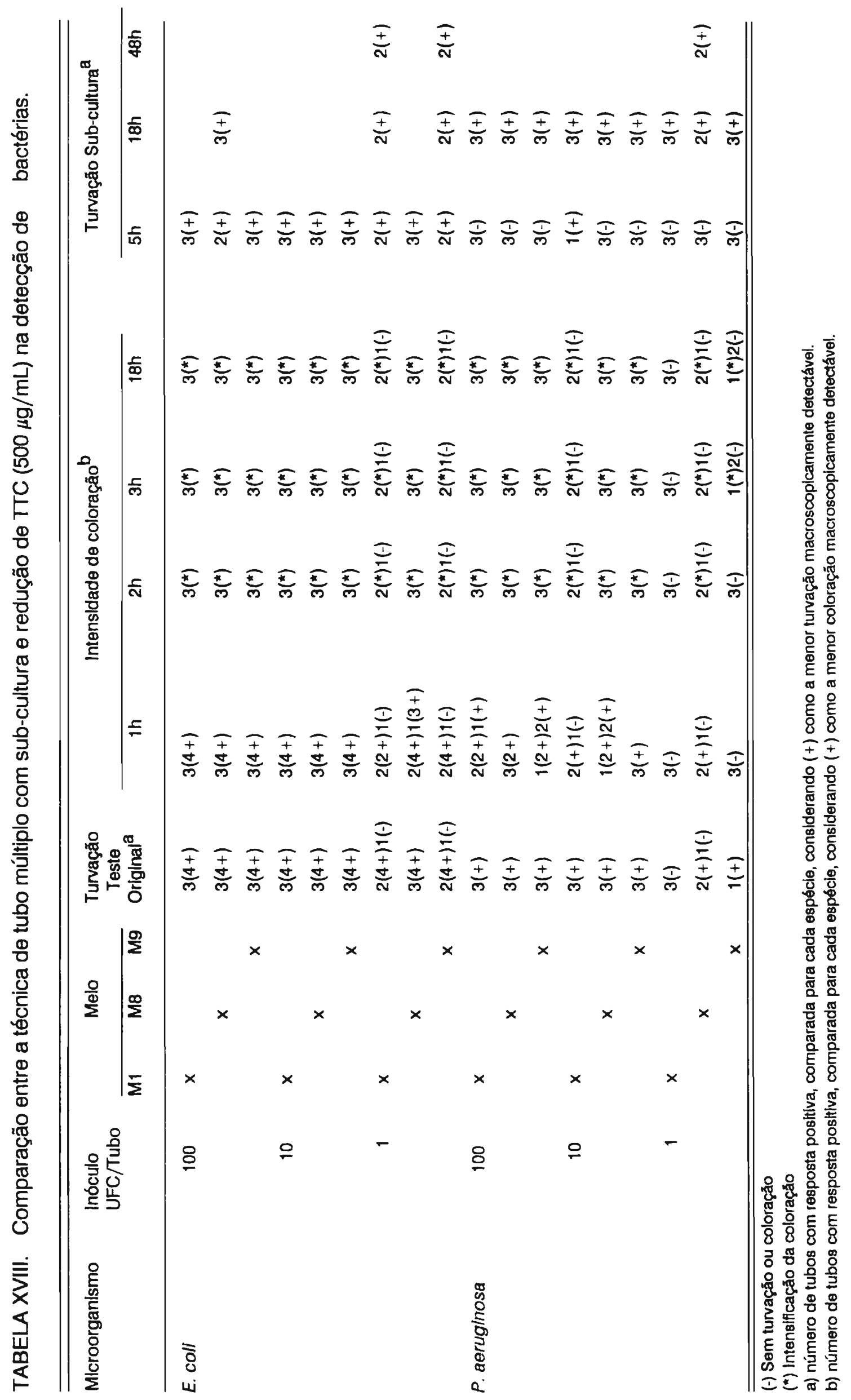




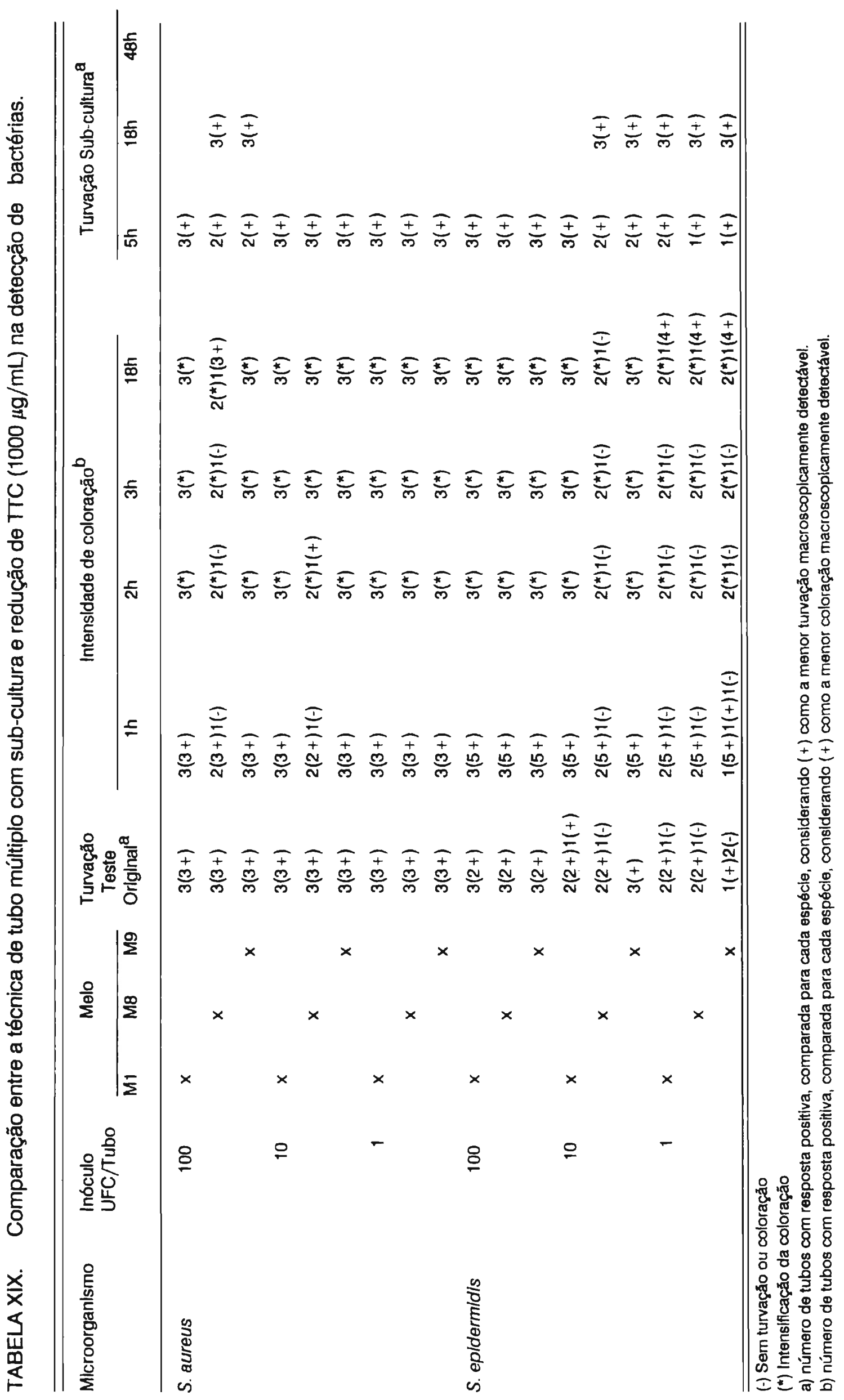




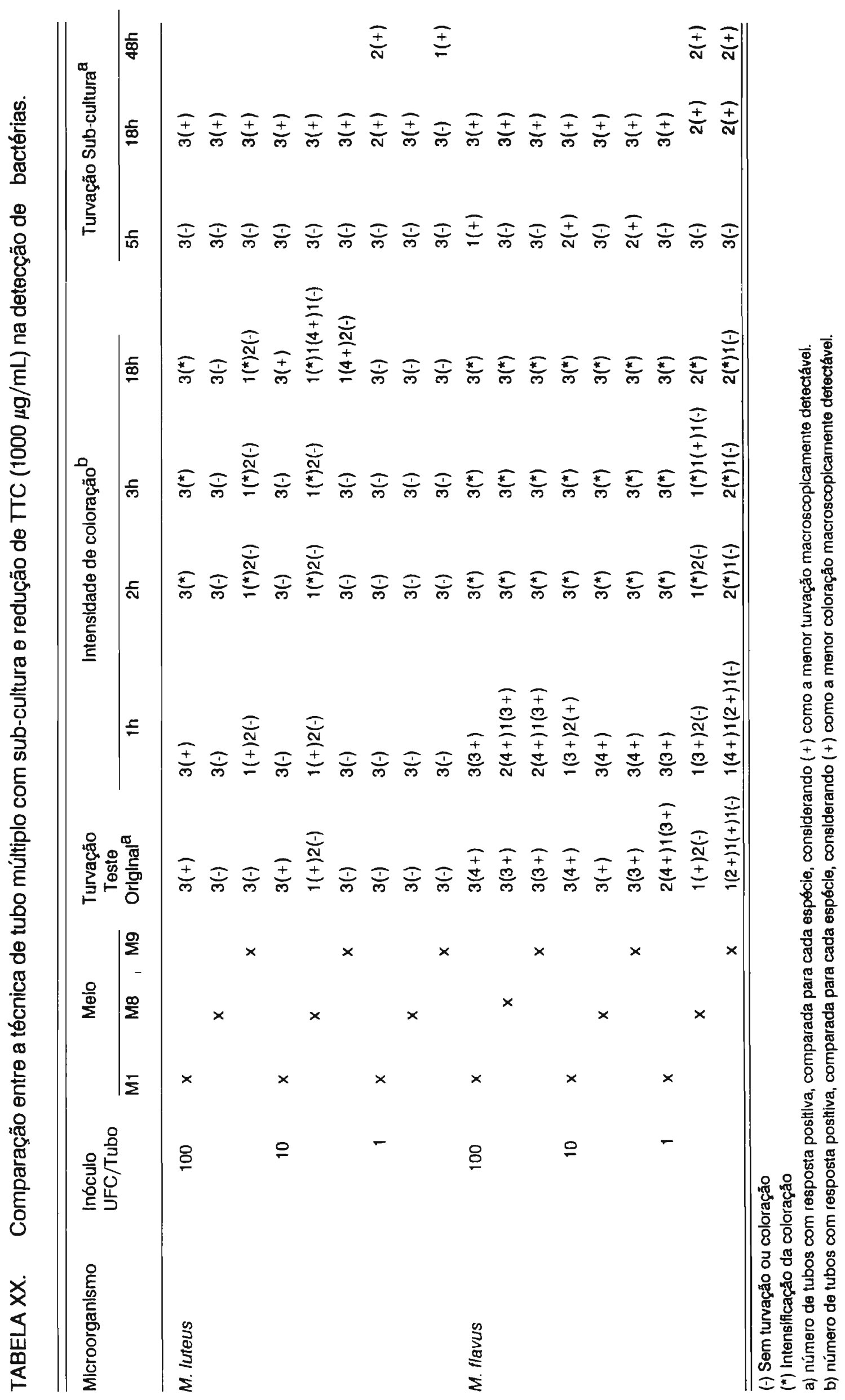




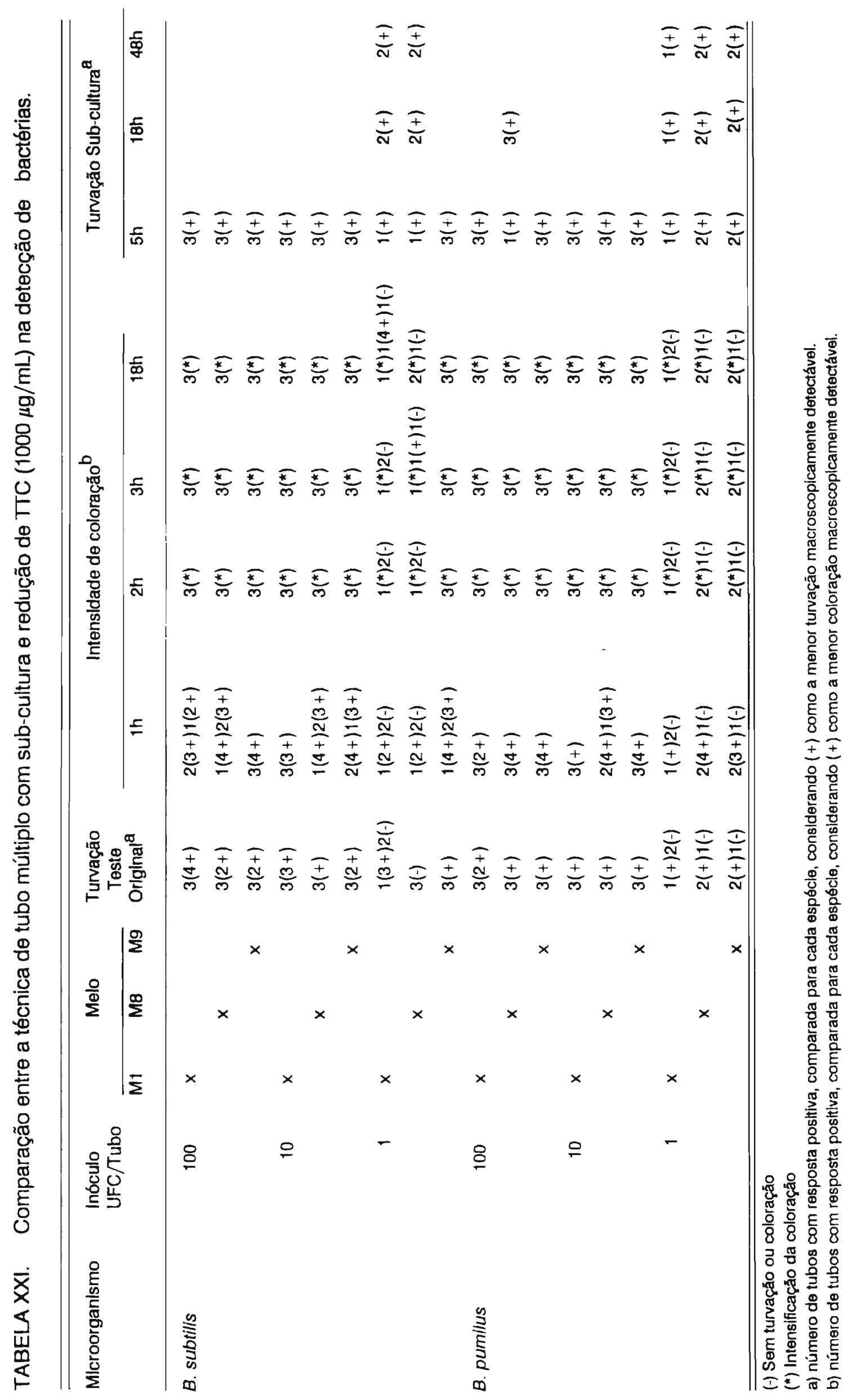




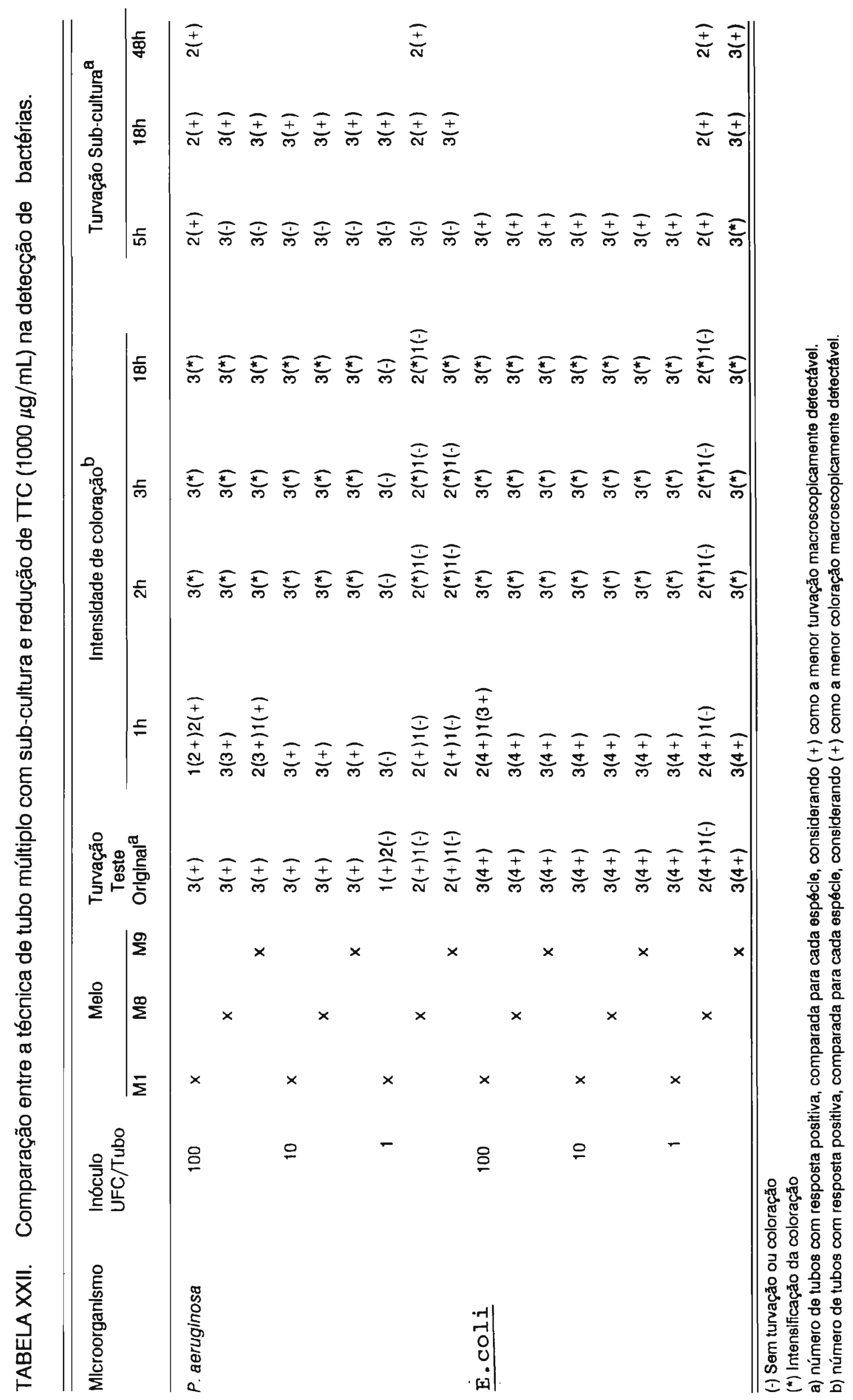




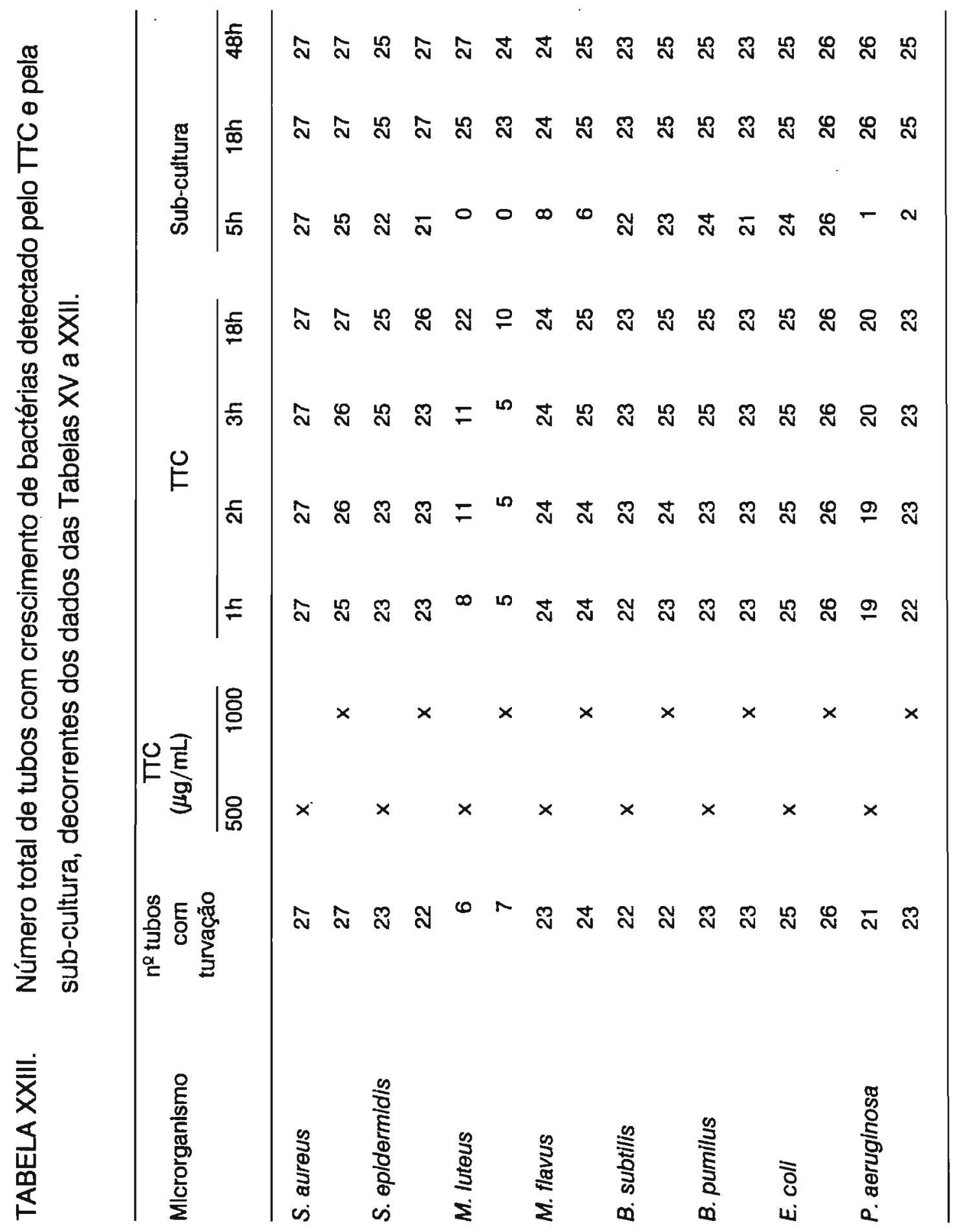




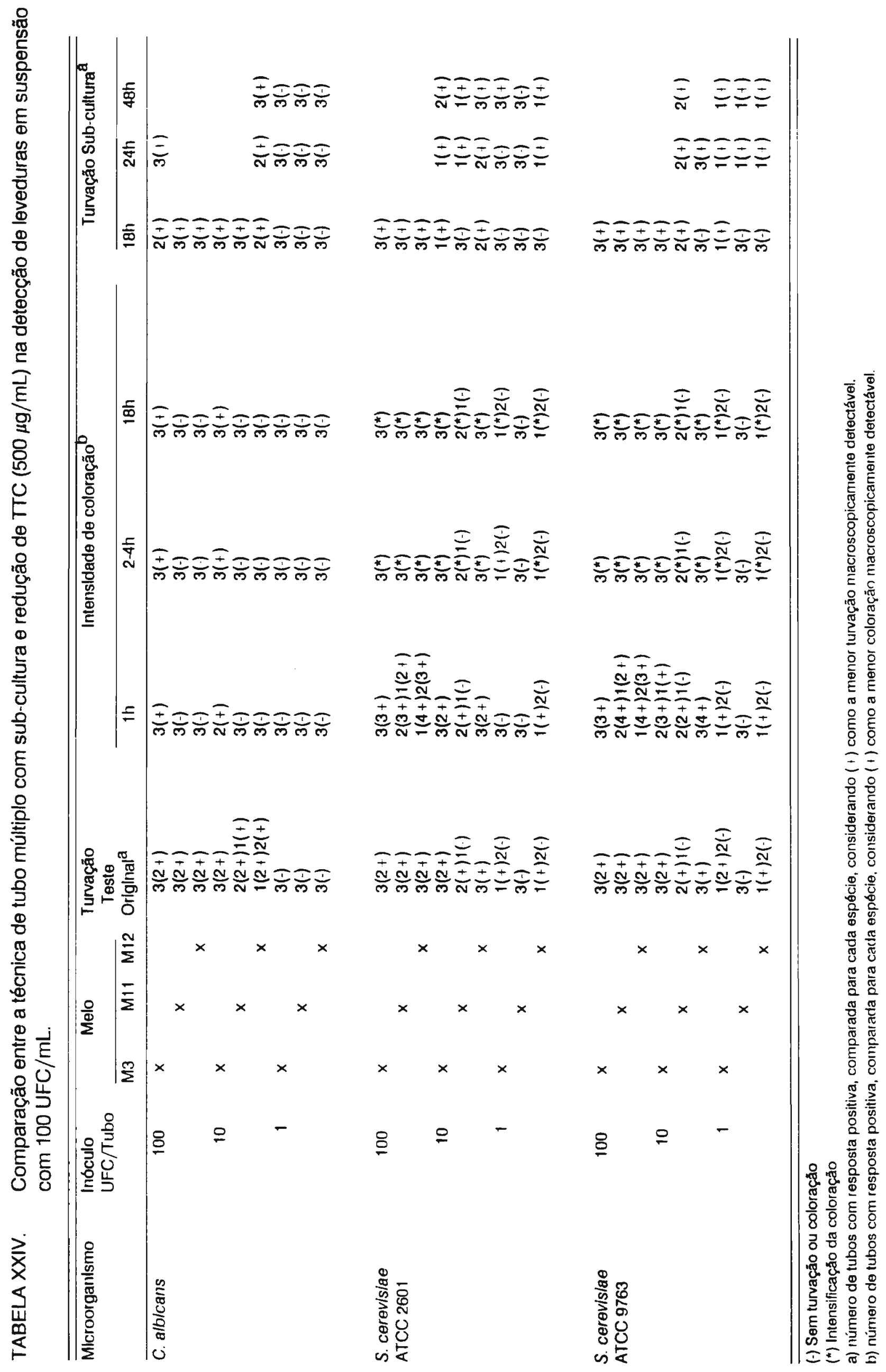




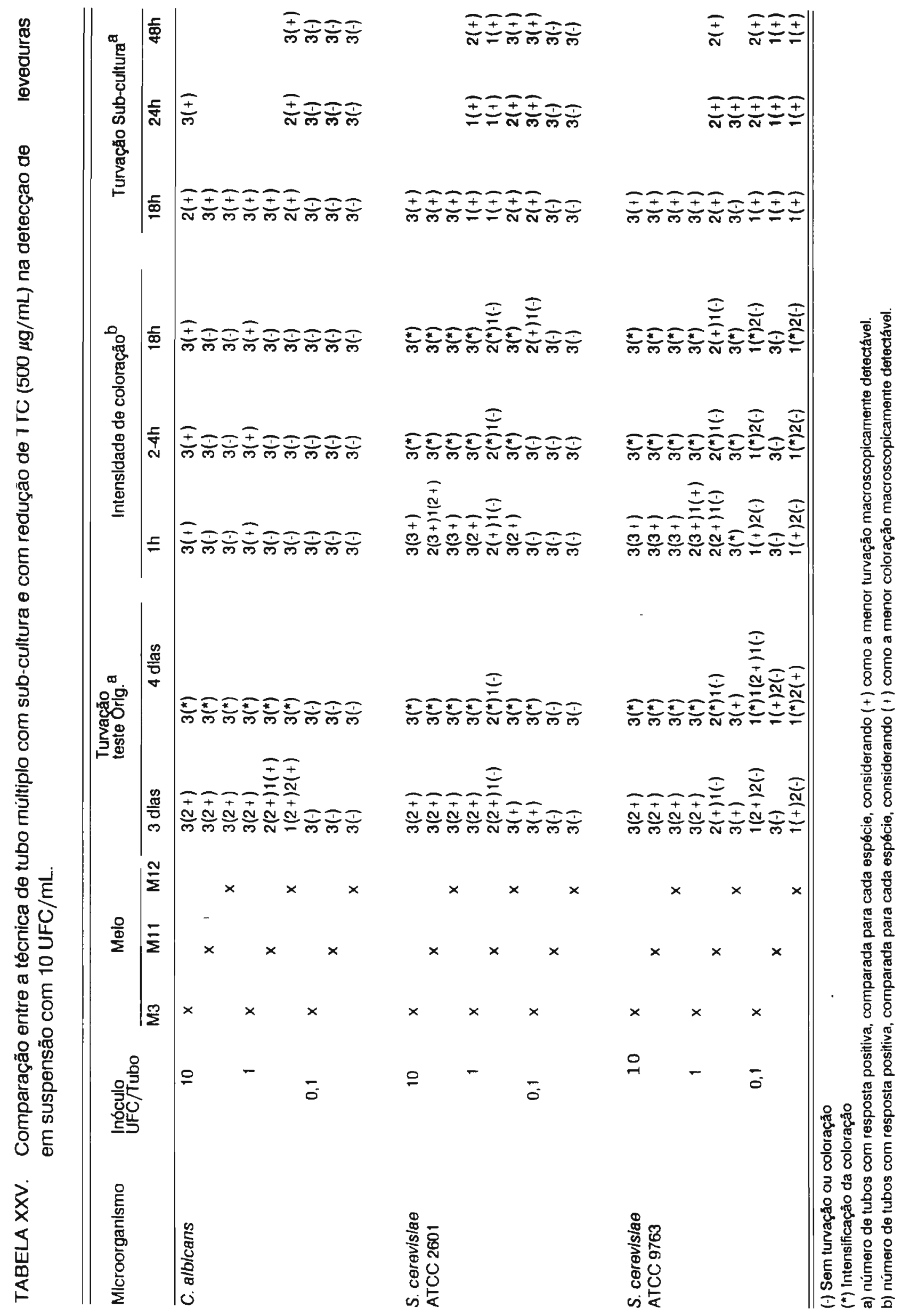




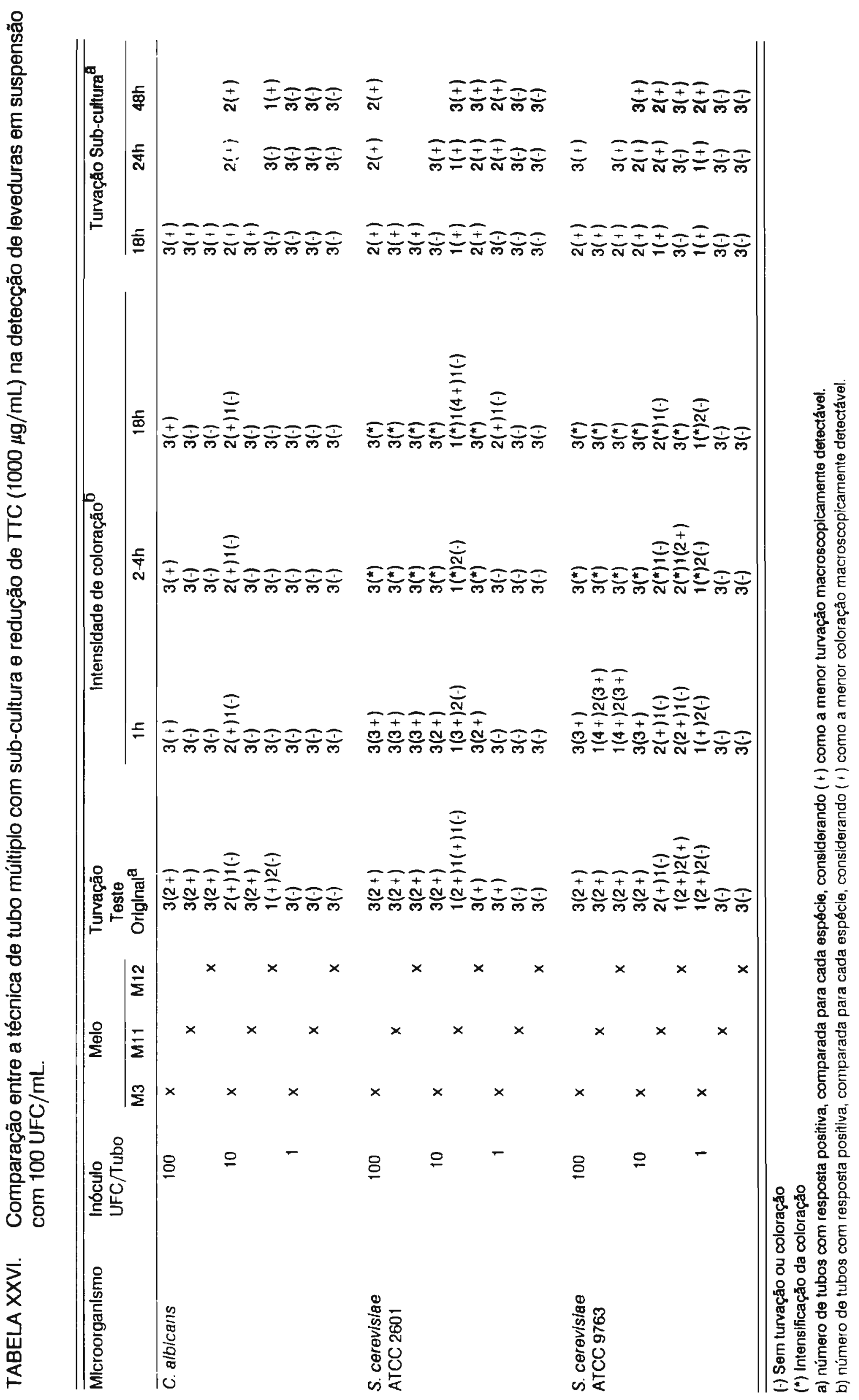




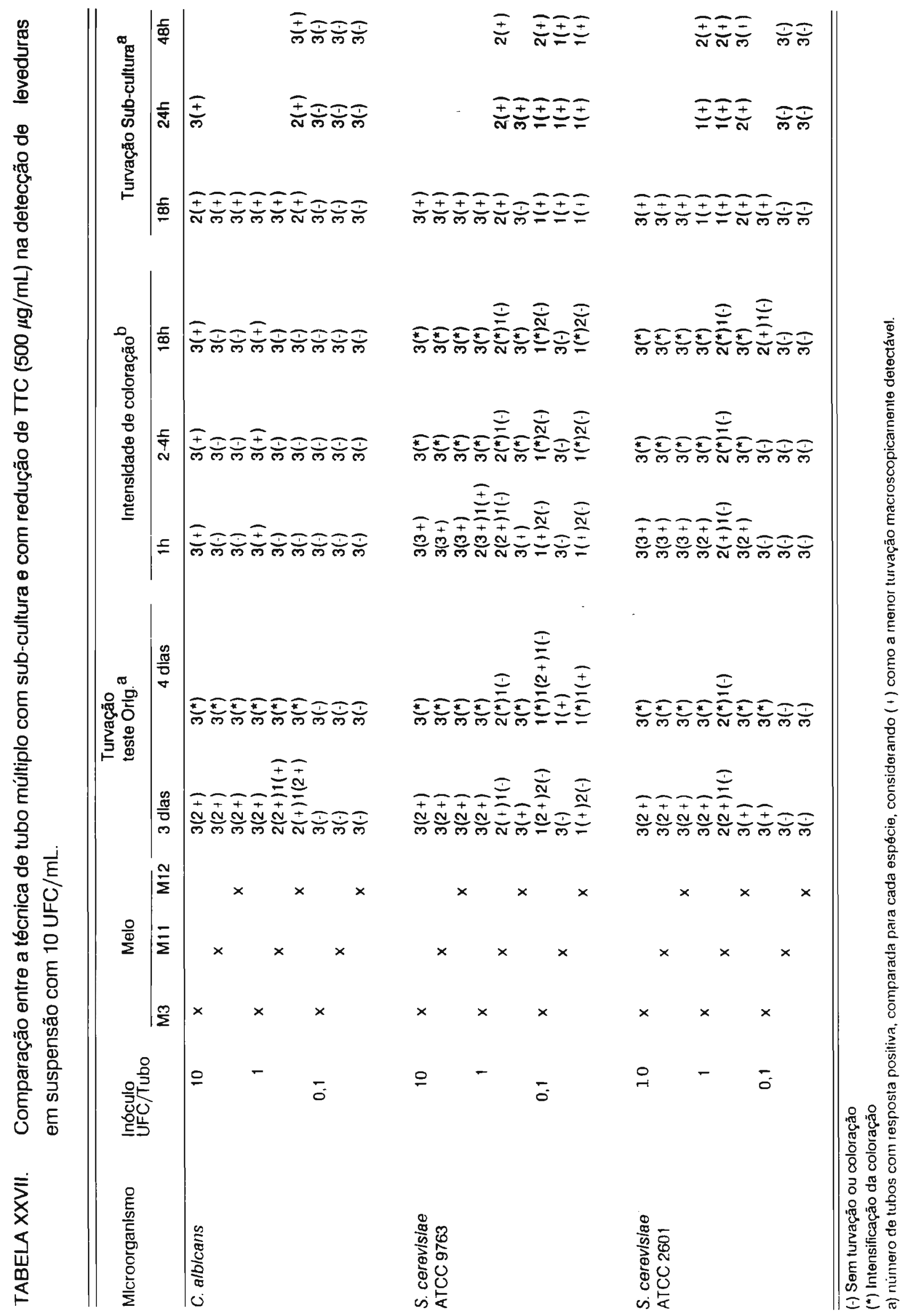


TABELA XXVIII. Número total de tubos com crescimento de leveduras detectado pelo TTC e pela sub-cultura com inóculo de 100, 10 e 1 UFC/tubo, decorrentes dos dados das Tabelas XXIV e XXVI.

\begin{tabular}{|c|c|c|c|c|c|c|c|c|c|}
\hline \multirow[t]{2}{*}{ Mlcroorganismo } & \multirow{2}{*}{$\begin{array}{r}\text { ne tubos } \\
\text { com } \\
\text { turvação }\end{array}$} & \multicolumn{2}{|c|}{$\begin{array}{c}\text { TTC } \\
(\mu \mathrm{g} / \mathrm{mL})\end{array}$} & \multicolumn{3}{|c|}{ TTC } & \multicolumn{3}{|c|}{ SUB-CULTURA } \\
\hline & & $\overline{500}$ & 1000 & 1h & 4h & $18 \mathrm{~h}$ & $\overline{18 h}$ & $24 h$ & $48 \mathrm{~h}$ \\
\hline S. cerevisian & 19 & $x$ & & 19 & 19 & 19 & 15 & 20 & 20 \\
\hline ATCC 9763 & 18 & & $x$ & 17 & 17 & 18 & 11 & 15 & 19 \\
\hline \multicolumn{10}{|l|}{ S. cerevisien } \\
\hline \multirow[t]{2}{*}{ ATCC 2601} & 18 & $x$ & & 17 & 18 & 18 & 12 & 13 & 18 \\
\hline & 19 & & $x$ & 19 & 19 & 20 & 11 & 16 & 20 \\
\hline \multirow[t]{2}{*}{ C. alblcans } & 18 & $x$ & & 5 & 5 & 6 & 16 & 17 & 18 \\
\hline & 15 & & $x$ & 5 & 5 & 5 & 14 & 14 & 15 \\
\hline
\end{tabular}

TABELA XXIX - Número total de tubos com crescimento de leveduras detectado pelo TTC e pela sub-cultura com inóculo de 10, 1 e 0,1 UFC/tubo, decorrentes dos dados das Tabelas XXV e XXVII.

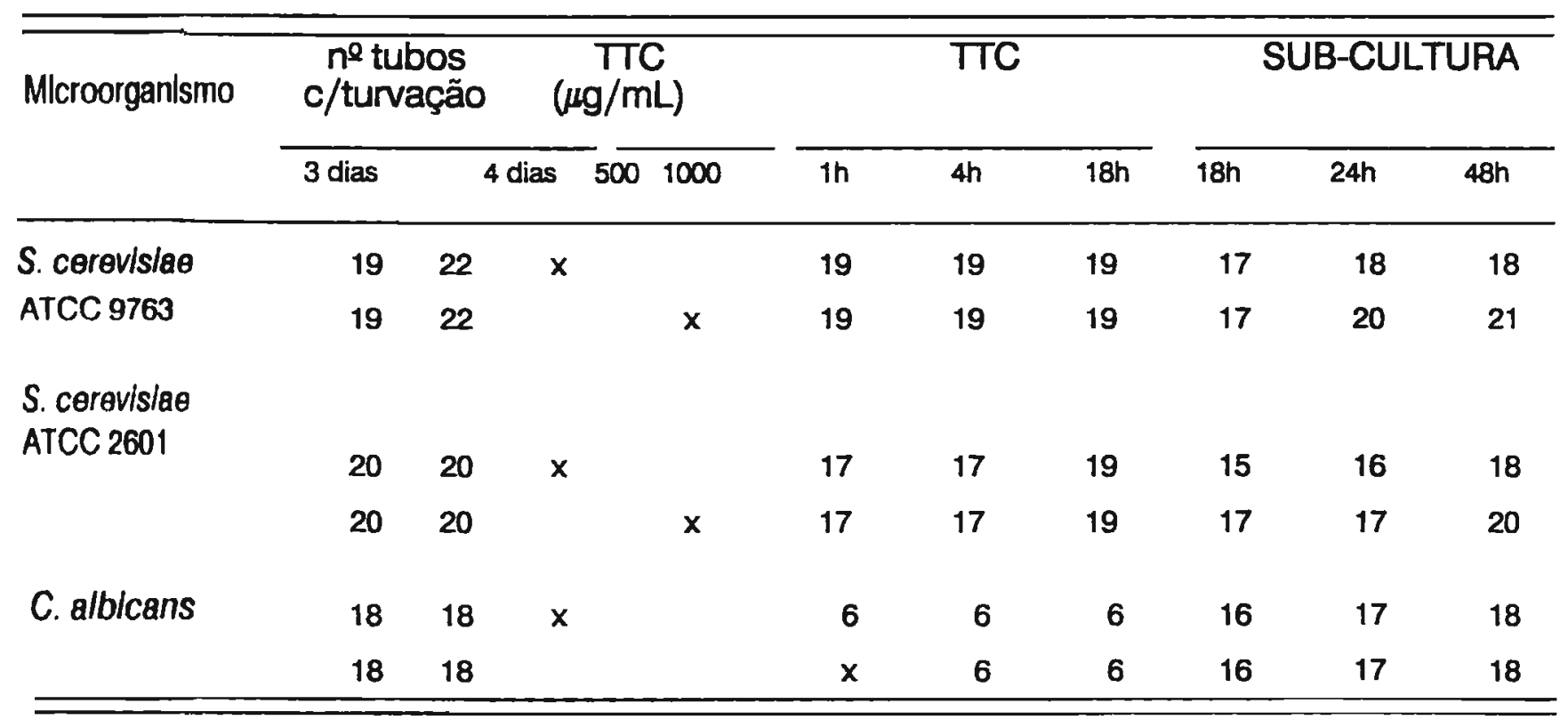


TABELA XXX. Comparação entre a técnica de tubo múltiplo com sub-cultura e redução de TTC em meio alcalino na detecção de $C$. albicans.

\begin{tabular}{|c|c|c|c|c|c|c|c|c|c|}
\hline \multirow{2}{*}{$\begin{array}{c}\text { Inóculo } \\
\text { (UFC/tubo) }\end{array}$} & \multicolumn{2}{|c|}{ Meio } & \multirow{2}{*}{$\begin{array}{c}\text { Turvaçäo } \\
\text { Teste } \\
\text { orlginal }^{a}\end{array}$} & \multirow[t]{2}{*}{$\mathrm{Na}(\mathrm{OH})$} & \multicolumn{3}{|c|}{$\mathrm{TTC}(\mu \mathrm{g} / \mathrm{mL})$} & \multirow{2}{*}{$\begin{array}{c}\text { Intensidade } \\
\text { coloração }\end{array}$} & \multirow{2}{*}{$\begin{array}{l}\text { Turvaçāo } \\
\text { Sub-cultura }\end{array}$} \\
\hline & M3 & M11 & & & 1000 & 2500 & 5000 & & \\
\hline \multirow[t]{4}{*}{100} & $x$ & & $3(2+)$ & & $\bar{x}$ & & & $3(+)$ & $3(+)$ \\
\hline & $x$ & & $3(2+)$ & $x$ & $x$ & & & $3(2+)$ & $3(+)$ \\
\hline & & $x$ & $3(2+)$ & & $x$ & & & $3(-)$ & $3(+)$ \\
\hline & & $x$ & $3(2+)$ & $x$ & $x$ & & & $3(-)$ & $3(+)$ \\
\hline \multirow[t]{4}{*}{10} & $x$ & & $3(2+)$ & & $x$ & & & $3(+)$ & $3(+)$ \\
\hline & $x$ & & $3(2+)$ & $x$ & $x$ & & & $3(2+)$ & $3(+)$ \\
\hline & & $x$ & $3(2+)$ & & $x$ & & & $3(-)$ & $3(+)$ \\
\hline & & $x$ & $3(2)$ & $x$ & $x$ & & & $3(-)$ & $3(+)$ \\
\hline \multirow[t]{4}{*}{1} & $x$ & & $3(2)$ & & $x$ & & & $3(t)$ & $3(+)$ \\
\hline & $x$ & & $2(2+)$ & $x$ & $x$ & & & $2(2+)$ & $2(+)$ \\
\hline & & $x$ & $3(2+)$ & & $x$ & & & $3(-)$ & $3(+)$ \\
\hline & & $x$ & $3(2+)$ & $x$ & $x$ & & & $3(-)$ & $3(+)$ \\
\hline \multirow[t]{4}{*}{100} & $x$ & & $3(2+)$ & & & $x$ & & $3(2+)$ & $3(+)$ \\
\hline & $x$ & & $3(2+)$ & $x$ & & $x$ & & $3(4+)$ & $3(+)$ \\
\hline & & $x$ & $3(2+)$ & & & $x$ & & $3(+)$ & $3(+)$ \\
\hline & & $x$ & $3(2+)$ & $x$ & & $x$ & & $3(2+)$ & $3(+)$ \\
\hline \multirow[t]{4}{*}{10} & $x$ & & $3(2+)$ & & & $x$ & & $3(2+)$ & $3(+)$ \\
\hline & $x$ & & $3(2+)$ & $x$ & & $x$ & & $3(4+)$ & $31+1$ \\
\hline & & $x$ & $3(2+)$ & & & $x$ & & $3(+)$ & $3(+)$ \\
\hline & & $x$ & $3(2+)$ & $x$ & & $x$ & & $3(2+)$ & $3(+)$ \\
\hline \multirow[t]{4}{*}{1} & $x$ & & $2(2+)$ & & & $x$ & & $2(2+)$ & $2(+)$ \\
\hline & $x$ & & $3(2+)$ & $x$ & & $x$ & & $3(4+)$ & $3(+)$ \\
\hline & & $x$ & $2(2+)$ & & & $x$ & & $2(+)$ & $2(+)$ \\
\hline & & $x$ & $2(2+)$ & $x$ & & $x$ & & $2(2+)$ & $2(+)$ \\
\hline \multirow[t]{4}{*}{100} & $x$ & & $3(2+)$ & & & & $x$ & $3(3+)$ & $3(+)$ \\
\hline & $x$ & & $3(2+)$ & $x$ & & & $x$ & $3(5+)$ & $3(+)$ \\
\hline & & $x$ & $3(2+)$ & & & & $x$ & $3(+)$ & $3(+)$ \\
\hline & & $x$ & $3(2+)$ & $x$ & & & $x$ & $3(3+)$ & $3(+)$ \\
\hline \multirow[t]{4}{*}{10} & $x$ & & $3(2+)$ & & & & $x$ & $3(3+)$ & $3(+)$ \\
\hline & $x$ & & $3(2+)$ & $x$ & & & $x$ & $3(5+)$ & $3(+)$ \\
\hline & & $x$ & $3(2+)$ & & & & $x$ & $3(+)$ & $3(+)$ \\
\hline & & $x$ & $3(2+)$ & $x$ & & & $x$ & $3(3+)$ & $3(+)$ \\
\hline \multirow[t]{4}{*}{1} & $x$ & & $3(2+)$ & & & & $x$ & $3(3+)$ & $3(+)$ \\
\hline & $x$ & & $3(2+)$ & $x$ & & & $x$ & $3(5+)$ & $3(+)$ \\
\hline & & $x$ & $3(2+)$ & & & & $x$ & $3(+)$ & $3(+)$ \\
\hline & & $x$ & $2(2+)$ & $x$ & & & $x$ & $2(3+)$ & $2(+)$ \\
\hline
\end{tabular}

(-) sem coloraçăo

a) número de tubos com resposta positiva, comparada para cada espécie, considerando ( + ) como a menor turvaçāo macroscopicamente detectável.

b) número de tubos com resposta positiva, comparada para cada espécie, considerando $(+)$ como a menor coloração macroscopicamente detectável. 
TABELA XXXI. Avaliação da atividade inibitória do polissorbato 20 (M8) e 80 (M10) e da lecitina de soja (M9) adicionados ao caldo de caseína-soja (M1).

\begin{tabular}{|c|c|c|c|c|c|c|c|c|}
\hline \multirow{2}{*}{ Microrganismo } & \multirow{2}{*}{$\begin{array}{l}\text { UFC/ } \\
\text { tubo }\end{array}$} & \multicolumn{3}{|c|}{ Tempo (h) } & \multicolumn{4}{|c|}{ Prop. de tubos c/turvação } \\
\hline & & 20 & 24 & 48 & $\overline{\mathrm{M} 1}$ & M8 & M10 & M9 \\
\hline \multirow[t]{9}{*}{ S. aureus } & 100 & $x$ & & & $10 / 10$ & $10 / 10$ & $10 / 10$ & $10 / 10$ \\
\hline & & & $x$ & & $10 / 10$ & $10 / 10$ & $10 / 10$ & $10 / 10$ \\
\hline & & & & $x$ & $10 / 10$ & $10 / 10$ & $10 / 10$ & $10 / 10$ \\
\hline & 10 & $x$ & & & $10 / 10$ & $10 / 10$ & $10 / 10$ & $10 / 10$ \\
\hline & & & $x$ & & $10 / 10$ & $10 / 10$ & $10 / 10$ & $10 / 10$ \\
\hline & & & & $x$ & $10 / 10$ & $10 / 10$ & $10 / 10$ & $10 / 10$ \\
\hline & 1 & $x$ & & & $4 / 10$ & $1 / 10$ & $3 / 10$ & $4 / 10$ \\
\hline & & & $x$ & & $4 / 10$ & $1 / 10$ & $3 / 10$ & $4 / 10$ \\
\hline & & & & $x$ & $4 / 10$ & $1 / 10$ & $3 / 10$ & $4 / 10$ \\
\hline \multirow[t]{9}{*}{ S. epidermidis } & 100 & $x$ & & & $10 / 10$ & $10 / 10$ & $7 / 10$ & $9 / 10$ \\
\hline & & & $x$ & & $10 / 10$ & $10 / 10$ & $9 / 10$ & $9 / 10$ \\
\hline & & & & $x$ & $10 / 10$ & $10 / 10$ & $9 / 10$ & $10 / 10$ \\
\hline & 10 & $x$ & & & $10 / 10$ & $9 / 10$ & $8 / 10$ & $9 / 10$ \\
\hline & & & $x$ & & $10 / 10$ & $9 / 10$ & $10 / 10$ & $10 / 10$ \\
\hline & & & & $x$ & $10 / 10$ & $10 / 10$ & $10 / 10$ & $10 / 10$ \\
\hline & 1 & $x$ & & & $9 / 10$ & $9 / 10$ & $7 / 10$ & $7 / 10$ \\
\hline & & & $x$ & & $10 / 10$ & $9 / 10$ & $9 / 10$ & $10 / 10$ \\
\hline & & & & $x$ & $10 / 10$ & $9 / 10$ & $9 / 10$ & $10 / 10$ \\
\hline \multirow[t]{9}{*}{ M. luteus } & 100 & $x$ & & & $10 / 10$ & $10 / 10$ & $10 / 10$ & $10 / 10$ \\
\hline & & & $x$ & & $10 / 10$ & $10 / 10$ & $10 / 10$ & $10 / 10$ \\
\hline & & & & $x$ & $10 / 10$ & $10 / 10$ & $10 / 10$ & $10 / 10$ \\
\hline & 10 & $x$ & & & $10 / 10$ & $1 / 10$ & $0 / 10$ & $1 / 10$ \\
\hline & & & $x$ & & $10 / 10$ & $1 / 10$ & $0 / 10$ & $1 / 10$ \\
\hline & & & & $x$ & $10 / 10$ & $10 / 10$ & $10 / 10$ & $9 / 10$ \\
\hline & 1 & $x$ & & & $3 / 10$ & $0 / 10$ & $1 / 10$ & $2 / 10$ \\
\hline & & & $x$ & & $3 / 10$ & $0 / 10$ & $1 / 10$ & $2 / 10$ \\
\hline & & & & $x$ & $8 / 10$ & $9 / 10$ & $6 / 10$ & $9 / 10$ \\
\hline
\end{tabular}


TABELA XXXII. Determinação da concentração mínima eficaz de TTC para revelação de colônias de $S$. aureus, $P$. aeruginosa, B. subtilis e E. coli.

\begin{tabular}{|c|c|c|c|c|c|c|c|c|c|c|c|c|}
\hline \multicolumn{2}{|c|}{ MEIO } & \multicolumn{2}{|c|}{$\begin{array}{l}\text { VOLUME POR } \\
\text { PLACAS (mL) }\end{array}$} & \multicolumn{3}{|c|}{$\begin{array}{l}\text { TEMPO DE } \\
\text { OBS. (MIN) }\end{array}$} & \multicolumn{2}{|c|}{$\begin{array}{l}\text { POSICLÃO DAS } \\
\text { COLÓNIAS }\end{array}$} & \multicolumn{4}{|c|}{$\pi \mathrm{TC}(\%)$} \\
\hline$M_{2}$ & $M_{13}$ & 15 & 20 & 15 & 30 & 60 & sup. & prof. & 0.025 & 0.05 & 0.1 & 0.2 \\
\hline$x$ & & $x$ & & $x$ & & & $x$ & & $(+)$ & $(+)$ & $(+)$ & $(+)$ \\
\hline$x$ & & $x$ & & $x$ & & & & $x$ & $(-)$ & $(-)$ & $(-)$ & $(-)$ \\
\hline$x$ & & $x$ & & & $x$ & & $x$ & & $(+)$ & $(+)$ & $(+)$ & $(+)$ \\
\hline$x$ & & $x$ & & & $x$ & & & $x$ & $(-)$ & $(-)$ & $(-)$ & $(+)$ \\
\hline$x$ & & $x$ & & & & $x$ & $x$ & & $(+)$ & $(+)$ & $(+)$ & $(+)$ \\
\hline$x$ & & $x$ & & & & $x$ & & $x$ & $(+)$ & $(+)$ & $(+)$ & $(+)$ \\
\hline$x$ & & & $x$ & $x$ & & & $x$ & & $(+)$ & $(+)$ & $(+)$ & $(+)$ \\
\hline$x$ & & & $x$ & $x$ & & & & $x$ & $(-)$ & $(-)$ & $(-)$ & $(-)$ \\
\hline$x$ & & & $x$ & & $x$ & & $x$ & & $(+)$ & $(+)$ & $(+)$ & $(+)$ \\
\hline$x$ & & & $x$ & & $x$ & & & $x$ & $(-)$ & $(-)$ & $(-)$ & $(-)$ \\
\hline$x$ & & & $x$ & & & $x$ & $x$ & & $(+)$ & $(+)$ & $(+)$ & $(+)$ \\
\hline$x$ & & & $x$ & & & $x$ & & $x$ & $(+)$ & $(+)$ & $(+)$ & $(+)$ \\
\hline & $x$ & $x$ & & $x$ & & & $x$ & & $(+)$ & $(+)$ & $(+)$ & $(+)$ \\
\hline & $x$ & $x$ & & $x$ & & & & $x$ & $(-)$ & $H$ & $(-)$ & $(-)$ \\
\hline & $x$ & $x$ & & & $x$ & & $x$ & & $(+)$ & $(+)$ & $(+)$ & $(+)$ \\
\hline & $x$ & $x$ & & & $x$ & & & $x$ & $(-)$ & $\theta$ & $(-)$ & $(+)$ \\
\hline & $x$ & $x$ & & & & $x$ & $x$ & & $(+)$ & $(+)$ & $(+)$ & $(t)$ \\
\hline & $x$ & $x$ & & & & $x$ & & $x$ & $(+)$ & $(+)$ & $(+)$ & $(+)$ \\
\hline & $x$ & & $x$ & $x$ & & & $x$ & & $(+)$ & $(+)$ & $(+)$ & $(+)$ \\
\hline & $x$ & & $x$ & $x$ & & & & $x$ & $(-)$ & $(-)$ & $(-)$ & $(-)$ \\
\hline & $x$ & & $x$ & & $x$ & & $x$ & & $(+)$ & $(+)$ & $(+)$ & $(+)$ \\
\hline & $x$ & & $x$ & & $x$ & & & $x$ & $(-)$ & $(H)$ & $(-)$ & $(-)$ \\
\hline & $x$ & & $x$ & & & $x$ & $x$ & & $(+)$ & $(+)$ & $(+)$ & $(+)$ \\
\hline & $x$ & & $x$ & & & $x$ & & $x$ & $(+)$ & $(+)$ & $(+)$ & $(+)$ \\
\hline
\end{tabular}

(t)- Com coloração rosa a vermelha

(-) - Sem viragem do indicador 
TABELA XXXIII. Determinação da concentração mínima eficaz de TTC para revelação de colônias de leveduras.

\begin{tabular}{|c|c|c|c|c|c|c|c|c|c|c|}
\hline \multirow{2}{*}{$\begin{array}{l}\text { Microrga- } \\
\text { nismo }\end{array}$} & \multicolumn{2}{|c|}{ Meio } & \multicolumn{2}{|c|}{$\begin{array}{l}\text { Tempo de obs. } \\
\text { (h) }\end{array}$} & \multicolumn{2}{|c|}{$\begin{array}{l}\text { Posição das } \\
\text { colónias }\end{array}$} & \multicolumn{4}{|c|}{ TTC (\%) } \\
\hline & M4 & M13 & 1 & 2 & sup. & prof. & $0,1-0,2$ & 0,5 & 1,0 & 2,0 \\
\hline S. cerevisiae & $x$ & & $x$ & & $\bar{x}$ & & $(4+)$ & $(4+)$ & $(4+)$ & $\overline{(4+)}$ \\
\hline \multirow[t]{7}{*}{ ATCC 2601} & $x$ & & $x$ & & & $x$ & $(2+)$ & $(3+)$ & $(3+)$ & $(3+)$ \\
\hline & $x$ & & & $x$ & $\dot{x}$ & & $(4+)$ & $(5+)$ & $(5+)$ & $(5+)$ \\
\hline & $x$ & & & $x$ & & $x$ & $(2+)$ & $(4+)$ & $(4+)$ & $(4+)$ \\
\hline & & $x$ & $x$ & & $x$ & & $(4+)$ & $(4+)$ & $(4+)$ & $(4+)$ \\
\hline & & $x$ & $x$ & & & $x$ & $(+)$ & $(2+)$ & $(2+)$ & $(3+)$ \\
\hline & & $x$ & & $x$ & $x$ & & $(4+)$ & $(5+)$ & $(5+)$ & $(5+)$ \\
\hline & & $x$ & & $x$ & & $x$ & $(2+)$ & $(3+)$ & $(3+)$ & $(3+)$ \\
\hline \multirow[t]{8}{*}{ C. albicans } & $x$ & & $x$ & & $x$ & & $(2+)$ & $(3+)$ & $(3+)$ & $(3+)$ \\
\hline & $x$ & & $x$ & & & $x$ & $(-)$ & $(+)$ & $(t)$ & $(+)^{\prime}$ \\
\hline & $x$ & & & $x$ & $x$ & & $(2+)$ & $(3+)$ & $(4+)$ & $(4+)$ \\
\hline & $x$ & & & $x$ & & $x$ & $(-)$ & $(2+)$ & $(2+)$ & $(2+)$ \\
\hline & & $x$ & $x$ & & $x$ & & $(+)$ & $(2+)$ & $(2+)$ & $(2+)$ \\
\hline & & $x$ & $x$ & & & $x$ & $(-)$ & $(-)$ & $(-)$ & $(-)$ \\
\hline & & $x$ & & $x$ & $x$ & & $(2+)$ & $(3+)$ & $(3+)$ & $(3+)$ \\
\hline & & $x$ & & $x$ & & $x$ & $(-)$ & $(+)$ & $(+)$ & $(+)$ \\
\hline
\end{tabular}

$(\mathrm{n}+)$ - intensidade de coloraçäo rosa a vermelha

(h) - colónias brancas 
TABELA XXXIV. Determinação da concentração mínima eficaz de TTC em tampão pH 7,5 para revelação de colônias de leveduras.

\begin{tabular}{|c|c|c|c|c|c|c|c|c|c|c|}
\hline \multirow{2}{*}{$\begin{array}{l}\text { Microrga- } \\
\text { nismo }\end{array}$} & \multicolumn{2}{|c|}{ Meio } & \multicolumn{2}{|c|}{$\begin{array}{c}\text { Tempo de obs. } \\
\text { (h) }\end{array}$} & \multicolumn{2}{|c|}{$\begin{array}{l}\text { Posição das } \\
\text { colônias }\end{array}$} & \multicolumn{4}{|c|}{$\pi C(\%)$} \\
\hline & M4 & M13 & 1 & 2 & sup. & prof. & $0,1-0,2$ & 0,5 & 1,0 & 2,0 \\
\hline \multirow{8}{*}{$\begin{array}{l}\text { S. cerevisiae } \\
\text { ATCC } 2601\end{array}$} & $x$ & & $x$ & & $x$ & & $(4+)$ & $(4+)$ & $(4+)$ & $\overline{(4+)}$ \\
\hline & $x$ & & $x$ & & & $x$ & $(2+)$ & $(3+)$ & $(3+)$ & $(3+)$ \\
\hline & $x$ & & & $x$ & $x$ & & $(4+)$ & $(5+)$ & $(5+)$ & $(5+)$ \\
\hline & $x$ & & & $x$ & & $x$ & $(3+)$ & $(4+)$ & $(4+)$ & $(4+)$ \\
\hline & & $x$ & $x$ & & $x$ & & $(3+)$ & $(4+)$ & $(4+)$ & $(4+)$ \\
\hline & & $x$ & $x$ & & & $x$ & $(+)$ & $(2+)$ & $(2+)$ & $(2+)$ \\
\hline & & $x$ & & $x$ & $x$ & & $(4+)$ & $(5+)$ & $(5+)$ & $(5+)$ \\
\hline & & $x$ & & $x$ & & $x$ & $(+)$ & $(3+)$ & $(3+)$ & $(3+)$ \\
\hline \multirow[t]{8}{*}{ C. albicans } & $x$ & & $x$ & & $x$ & & $(3+)$ & $(4+)$ & $(4+)$ & $(4+)$ \\
\hline & $x$ & & $x$ & & & $x$ & $(+)$ & $(2+)$ & $(2+)$ & $(2+)$ \\
\hline & $x$ & & & $x$ & $x$ & & $(4+)$ & $(5+)$ & $(5+)$ & $(5+)$ \\
\hline & $x$ & & & $x$ & & $x$ & $(2+)$ & $(3+)$ & $(3+)$ & $3+i$ \\
\hline & & $x$ & $x$ & & $x$ & & $(+)$ & $(4+)$ & $(4+)$ & $(4+)$ \\
\hline & & $x$ & $x$ & & & $x$ & $-(-)$ & $\theta$ & $(-)$ & $(-)$ \\
\hline & & $x$ & & $x$ & $x$ & & $(2+)$ & $(5+)$ & $(5+)$ & $(5+)$ \\
\hline & & $x$ & & $x$ & & $x$ & $(-)$ & $(2+)$ & $(2+)$ & $(2+)$ \\
\hline
\end{tabular}

$(n+)$ - intensidade de coloração rosa a vermelha

(n) - colônias brancas 
TABELA XXXXV. Determinação da concentração mínima eficaz de TTC para revelação de colônias de bactérias em meio contendo 0,3 e $0,4 \%$ de hidróxido de alumínio.

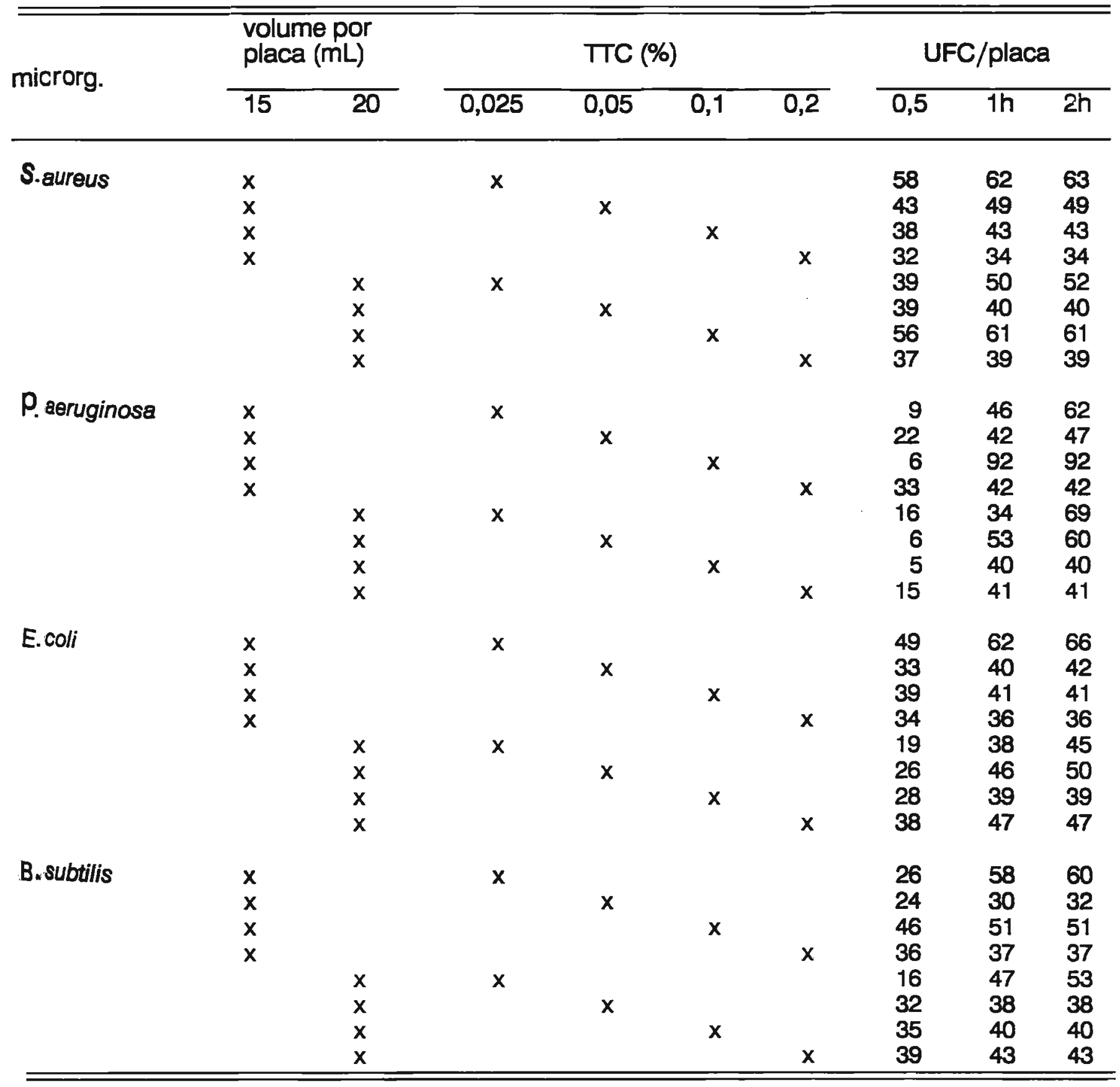


TABELA XXXXVI. Determinação da concentração rnínima eficaz de TTC em tampão pH 7,5 para revelação de colônias de $C$. albicans em meio contendo 0,3 e $0,4 \%$ de hidróxido de alumínio.

\begin{tabular}{|c|c|c|c|c|c|c|c|c|c|c|}
\hline \multicolumn{2}{|c|}{ meio } & \multicolumn{2}{|c|}{$\begin{array}{l}\text { volume por } \\
\text { placa (mL) }\end{array}$} & \multicolumn{3}{|c|}{ TTC (\%) } & \multicolumn{4}{|c|}{ UFC/placa } \\
\hline$\overline{M_{4}}$ & $\overline{M_{14}}$ & 15 & 20 & 0,5 & 1,0 & 2,0 & 0,5 & $1 \mathrm{~h}$ & $2 h$ & $3 h$ \\
\hline$x$ & & $x$ & & $x$ & & & 22 & 42 & 62 & 68 \\
\hline$x$ & & $x$ & & & $x$ & & 25 & 58 & 64 & 64 \\
\hline$x$ & & $x$ & & & & $x$ & 17 & 57 & 58 & 58 \\
\hline$x$ & & & $x$ & $x$ & & & 19 & 32 & 54 & 61 \\
\hline$x$ & & & $x$ & & $x$ & & 13 & 28 & 43 & 49 \\
\hline$x$ & & & $x$ & & & $x$ & 19 & 49 & 60 & 60 \\
\hline & $x$ & $x$ & & $x$ & & & 13 & 25 & 32 & 37 \\
\hline & $x$ & $x$ & & & $x$ & & 12 & 21 & 35 & 36 \\
\hline & $x$ & $x$ & & & & $x$ & 10 & 30 & 37 & 37 \\
\hline & $x$ & & $x$ & $x$ & & & 10 & 15 & 37 & 41 \\
\hline & $x$ & & $x$ & & $x$ & & 5 & 16 & 34 & 37 \\
\hline & $x$ & & $x$ & & & $x$ & 15 & 36 & 48 & 48 \\
\hline
\end{tabular}


TABELA XXXVII - Carga viável de microganismos padröes em produtos comercializados pelas técnicas de tubos múltiplos e semeadura em profundidade, após revelação com TTC.

\begin{tabular}{|c|c|c|c|c|c|}
\hline \multirow[t]{2}{*}{ Amost } & \multirow[t]{2}{*}{ microrganismo } & \multicolumn{2}{|c|}{$\mathrm{NMP} / \mathrm{g}(\mathrm{mL})^{*}$} & \multicolumn{2}{|c|}{$\mathrm{UFC} / \mathrm{g}(\mathrm{mL})^{\star}$} \\
\hline & & $\begin{array}{l}\text { Sub-cultura } \\
\text { (Met.1) }\end{array}$ & $\begin{array}{r}\text { TTC } \\
\text { (Met.2) }\end{array}$ & $\begin{array}{c}\text { Diluição } \\
1: 10 \\
\text { (Met.3) }\end{array}$ & $\begin{array}{l}\text { Diluição } \\
1: 4 \\
\text { (Met.4) }\end{array}$ \\
\hline \multirow[t]{3}{*}{$\mathrm{F} 1$} & P. aeruginosa (Mi7) & $31 \pm 12,3$ & $31 \pm 12,3$ & $49 \pm 18,3$ & $44 \pm 8,6$ \\
\hline & B. subtilis (Mi5) & $145 \pm 87,9$ & $145 \pm 87,9$ & $98 \pm 26,5$ & $97 \pm 41,5$ \\
\hline & M. luteus (Mi3) & $41 \pm 36,2$ & $41 \pm 36,2$ & $62 \pm 22,7$ & $50 \pm 10,4$ \\
\hline \multirow[t]{2}{*}{ C1 } & P. aeruginosa (Mi7) & $213 \pm 140,8$ & $213 \pm 140,8$ & $168 \pm 35,8$ & $183 \pm 29,7$ \\
\hline & B. subtilis (Mi5) & $67 \pm 51,8$ & $67 \pm 51,8$ & $68 \pm 28,2$ & $52 \pm 17,2$ \\
\hline $\mathrm{C}_{2}$ & P. aeruginosa (Mi7) & $23 \pm 12,2$ & $23 \pm 12,2$ & $28 \pm 10,9$ & $21 \pm 9,2$ \\
\hline $\mathrm{C}_{3}$ & P. aeruginosa (Mi7) & $21 \pm 9,7$ & $21 \pm 9,7$ & $20 \pm 10,9$ & $36 \pm 7,9$ \\
\hline
\end{tabular}

TABELA XXXVIII - Comparação entre os métodos pelo Teste de Kruskal-Walis dos dados referentes a Tabela XXXVII.

\begin{tabular}{lrrl}
\hline \hline & $\mathrm{H}$ & $\mathrm{p}$ & \\
\hline F1-Mi7 & 7.12 & 0.0284 & $(\mathrm{t} 1$ \# $\mathrm{t} 3),(\mathrm{t} 1=\mathrm{t} 4),(\mathrm{t} 4=\mathrm{t} 3)$ \\
F1-Mi5 & 1.42 & 0.4917 & \\
F1-Mi3 & 3.93 & 0.1398 & \\
C1-Mi7 & 0.99 & 0.6108 & \\
C1-Mi5 & 1.52 & 0.4663 & $\mathrm{t}$ \# $(\mathrm{t} 1=\mathrm{t} 3)$ \\
C2-Mi7 & 1.39 & 0.4996 & \\
C3-Mi7 & 14.12 & $<0.0001$ & \\
\hline & & & \\
TOTAL & 3.53 & 0.1712 & \\
\hline \hline
\end{tabular}




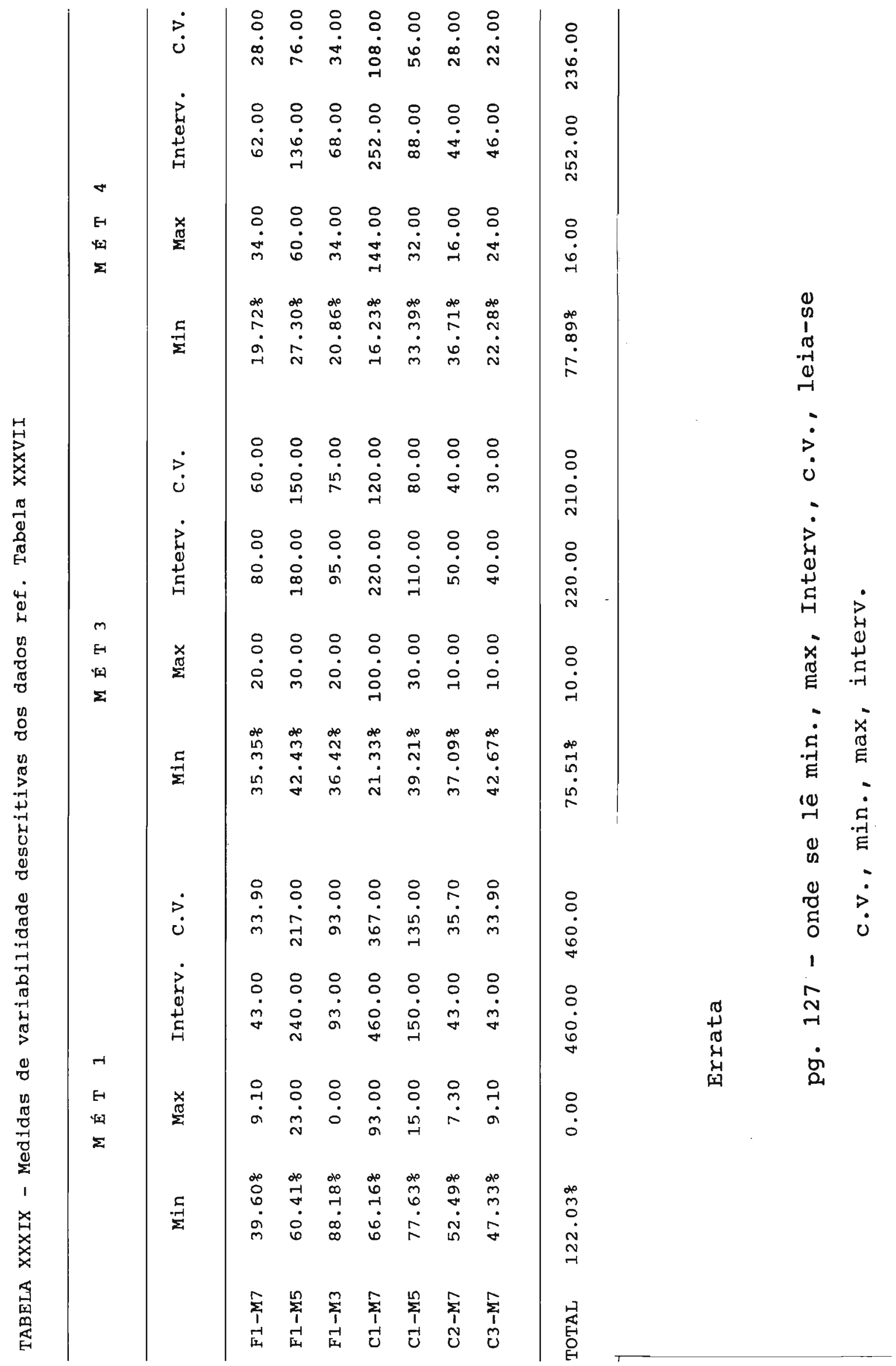


TABELA XL - Teste de Siegel-Tukey para variabilidade entre os métodos dos dados referentes a Tabela XXXVII.

\begin{tabular}{|c|c|c|c|c|}
\hline & $t 1 x+3$ & $t 1 \times t 4$ & t3 $x$ t4 & \\
\hline $\begin{array}{l}\mathrm{F} 1-\mathrm{Mi7} \\
\mathrm{F} 1-\mathrm{Mi5} \\
\text { F1-Mi3 } \\
\text { C1-Mi7 } \\
\text { C1-Mi5 } \\
\text { C2-Mi7 } \\
\text { C3-Mi7 }\end{array}$ & $\begin{array}{l}p=0.2332 \\
p=0.0821 \\
p=0.0445 \\
p=0.0010 \\
p=0.0093 \\
p=0.2867 \\
p=0.1524\end{array}$ & $\begin{array}{l}p=0.0942 \\
p=0.0376 \\
p=0.0262 \\
p=0.0026 \\
p=0.0177 \\
p=0.2885 \\
p=0.0376\end{array}$ & $\begin{array}{l}p=0.1862 \\
p=0.2885 \\
p=0.0821 \\
p=0.1524 \\
p=0.2531 \\
p=0.1862 \\
p=0.2208\end{array}$ & $\begin{array}{l}\mathrm{t} 1=\mathrm{t} 3=\mathrm{t} 4 \\
(\mathrm{t} 1 \# \mathrm{t} 4),(\mathrm{t} 1=\mathrm{t} 3),(\mathrm{t} 3=\mathrm{t} 4) \\
\mathrm{t} 1 \#(\mathrm{t} 3=\mathrm{t} 4) \\
\mathrm{t} 1 \#(\mathrm{t3}=\mathrm{t4}) \\
\mathrm{t} 1 \#(\mathrm{t} 3=\mathrm{t4}) \\
\mathrm{t} 1=\mathrm{t} 3=\mathrm{t4} \\
(\mathrm{t} 1 \# \mathrm{t} 4),(\mathrm{t} 1=\mathrm{t} 3),(\mathrm{t} 3=\mathrm{t} 4)\end{array}$ \\
\hline TOTAL & $p=0.0003$ & $p=0.0165$ & $p=0.0417$ & $\mathrm{t} 1$ \# t3 \# t4 \\
\hline
\end{tabular}

TABELA XLI - Teste de Friedman para coeficientes de variação dos dados referentes a Tabela XXXVII.

\begin{tabular}{lcccc}
\hline & MÉT. 1 & MÉT.3 & MÉT.4 & \\
\hline CV Medio & $-61.68 \%$ & $36.36 \%$ & $25.21 \%$ & $\mathrm{X}^{2}=14.00$ \\
CV Minimo & $39.60 \%$ & $21.33 \%$ & $16.23 \%$ & $\mathrm{p}<0.0001$ \\
CV Maximo & $88.18 \%$ & $42.67 \%$ & $36.71 \%$ & $\mathrm{t} 1$ \# $\mathrm{t3}$ \# t4 \\
$\mathrm{N}$ & 7 & 7 & 7 & \\
\hline \hline
\end{tabular}


TABELA XLII - Carga contaminante viável em produtos comercializados pelas técnicas de tubos múltiplos e semeadeira em profundidade após revelação com TTC.

\begin{tabular}{lccccc}
\hline \hline amostra & \multicolumn{2}{c}{$\mathrm{NMP/g( \textrm {mL } )}$} & \multicolumn{2}{c}{$\mathrm{UFC} / \mathrm{g}(\mathrm{mL})$} \\
\cline { 2 - 3 } \cline { 6 - 6 } & $\begin{array}{c}\text { sub-cultura } \\
\text { (Met.1) }\end{array}$ & $\begin{array}{c}\text { TTC } \\
\text { (Met.2) }\end{array}$ & $\begin{array}{c}\text { Diluição 1:10 } \\
\text { (Met.3) }\end{array}$ & $\begin{array}{c}\text { Diluição 1:4 } \\
\text { (Met.4) }\end{array}$ \\
\hline F2 & $22 \pm 12,8$ & $22 \pm 12,8$ & & $26 \pm 9,9$ & $23 \pm 5,9$ \\
F3 & $57 \pm 70,2$ & $57 \pm 70,2$ & & $36 \pm 10,2$ & $30 \pm 4,8$ \\
F4 & $74 \pm 64,7$ & $74 \pm 64,7$ & & $69 \pm 16,9$ & $68 \pm 17,1$ \\
F5 & $121 \pm 64,5$ & $121 \pm 64,5$ & & $58 \pm 15,8$ & $66 \pm 8,4$ \\
F6 & $209 \pm 111,4$ & $209 \pm 111,4$ & $151 \pm 25,5$ & $146 \pm 10,9$ \\
C4 & $116 \pm 71,8$ & $116 \pm 71,8$ & $52 \pm 20,9$ & $57 \pm 9,1$ \\
C5 & $103 \pm 56,5$ & $103 \pm 56,5$ & $76 \pm 18,6$ & $65 \pm 8,1$ \\
C6 & $81 \pm 62,3$ & $81 \pm 62,3$ & $58 \pm 14,0$ & $63 \pm 8,4$ \\
\hline \hline
\end{tabular}

Tabela XLIII - Comparação entre os métodos pelo Teste de Kruskal-Walis dos dados referentes a Tabela XLI.

\begin{tabular}{|c|c|c|c|}
\hline & $\mathrm{H}$ & $p$ & \\
\hline $\begin{array}{l}\text { F2 } \\
\text { F3 } \\
\text { F4 } \\
\text { F5 } \\
\text { F6 } \\
\text { C4 } \\
\text { C5 } \\
\text { C6 }\end{array}$ & $\begin{array}{l}1.81 \\
1.36 \\
1.31 \\
5.06 \\
2.00 \\
9.59 \\
6.40 \\
0.70\end{array}$ & $\begin{array}{l}0.3916 \\
0.5063 \\
0.5183 \\
0.0798 \\
0.3683 \\
0.0083 \\
0.0408 \\
0.7057\end{array}$ & $\begin{array}{l}(t 1 \# t 3),(t 1=t 4),(t 4=t 3) \\
(t 1 \# t 3),(t 1=t 4),(t 4=t 3) \\
(t 1 \# t 4),(t 1=t 3),(t 3=t 4)\end{array}$ \\
\hline TOTAL & 4.25 & 0.1195 & \\
\hline
\end{tabular}




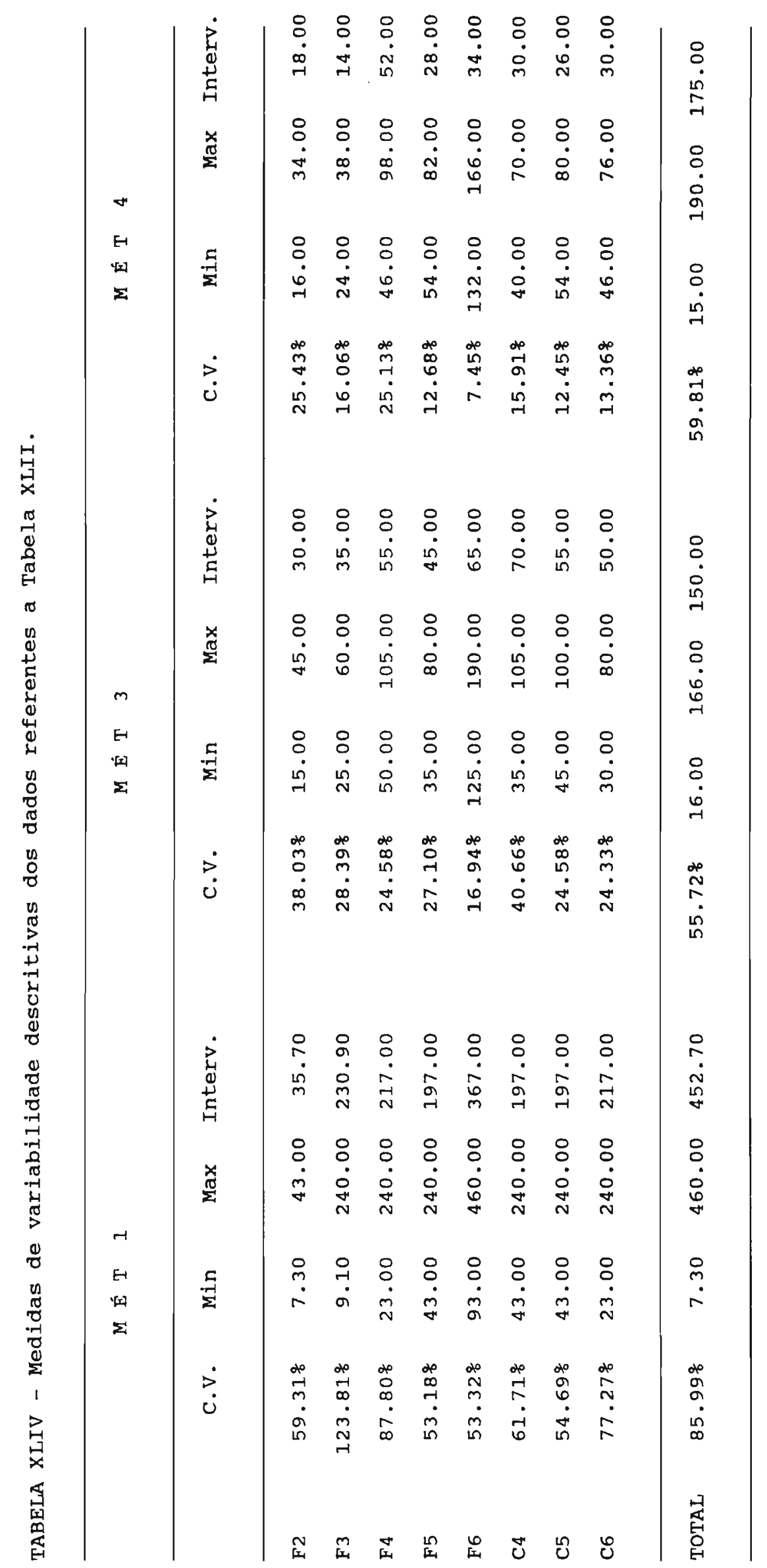


TABELA XLV - Teste de Siegel-Tukey para variabilidade entre os métodos dos dados referentes a Tabela XLI.

\begin{tabular}{lllll}
\hline & \multicolumn{1}{c}{$t 1 \times t 3$} & $t 1 \times t 4$ & $t 3 \times t 4$ & \\
\hline F2 & $p=0.2903$ & $p=0.2531$ & $p=0.0613$ & $t 1=t 3=t 4$ \\
F3 & $p=0.0010$ & $p=0.0001$ & $p=0.2531$ & $t 1 \#(t 3=t 4)$ \\
F4 & $p=0.0005$ & $p=0.0005$ & $p=0.2867$ & $t 1 \#(t 3=t 4)$ \\
F5 & $p=0.0116$ & $p=0.0003$ & $p=0.1073$ & $t 1 \#(t 3=t 4)$ \\
F6 & $p=0.0010$ & $p=0.0019$ & $p=0.0014$ & $t 1 \# t 3 \# t 4$ \\
C4 & $p=0.2867$ & $p=0.0177$ & $p=0.1862$ & $(t 1 \# t 4),(t 1=t 3),(t 3=t 4)$ \\
C5 & $p=0.2531$ & $p=0.0073$ & $p=0.0524$ & $(t 1 \# t 4),(t 1=t 3),(t 3=t 4)$ \\
C6 & $p=0.0001$ & $p=0.0001$ & $p=0.1862$ & $t 1 \#(t 3=t 4)$ \\
\hline TOTAL & & $p=0.0001$ & $p=0.0001$ & $p=0.1400 \quad t 1 \#(t 3=t 4)$ \\
\hline \hline
\end{tabular}

TABELA XLVI - Teste de Friedman para coeficientes de variação dos dados referentes a Tabela XLII.

\begin{tabular}{ccccc}
\hline \hline & MÉT.1 & MÉT.3 & MÉT.4 & \\
\hline CV Medio & $71.39 \%$ & $28.08 \%$ & $16.06 \%$ & $\mathrm{X}^{2}=14.25$ \\
CV Minimo & $53.18 \%$ & $16.94 \%$ & $7.45 \%$ & $\mathrm{p}<0.0001$ \\
CV Maximo & $123.81 \%$ & $40.66 \%$ & $25.43 \%$ & $\mathrm{t} 1$ \# t3 \# t4 \\
$\mathrm{N}$ & 8 & 8 & 8 & \\
\hline \hline
\end{tabular}


Fig. 1 - PRECISÃO DOS MÉTODOS AMOSTRAS COM MICRORG. PADROES

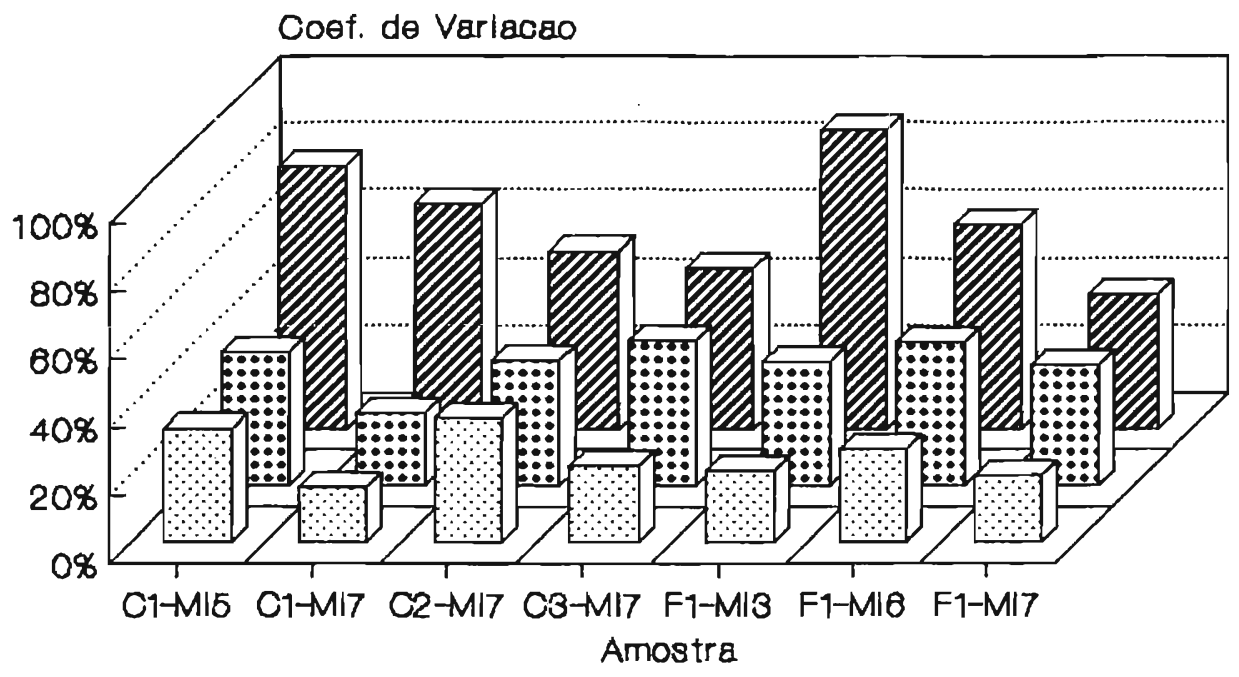

W Método 4 فétodo 3 WIIA Método 1

Fig. 2 - PRECISÃO DOS MÉTODOS AMOSTRAS CONTAMINADAS

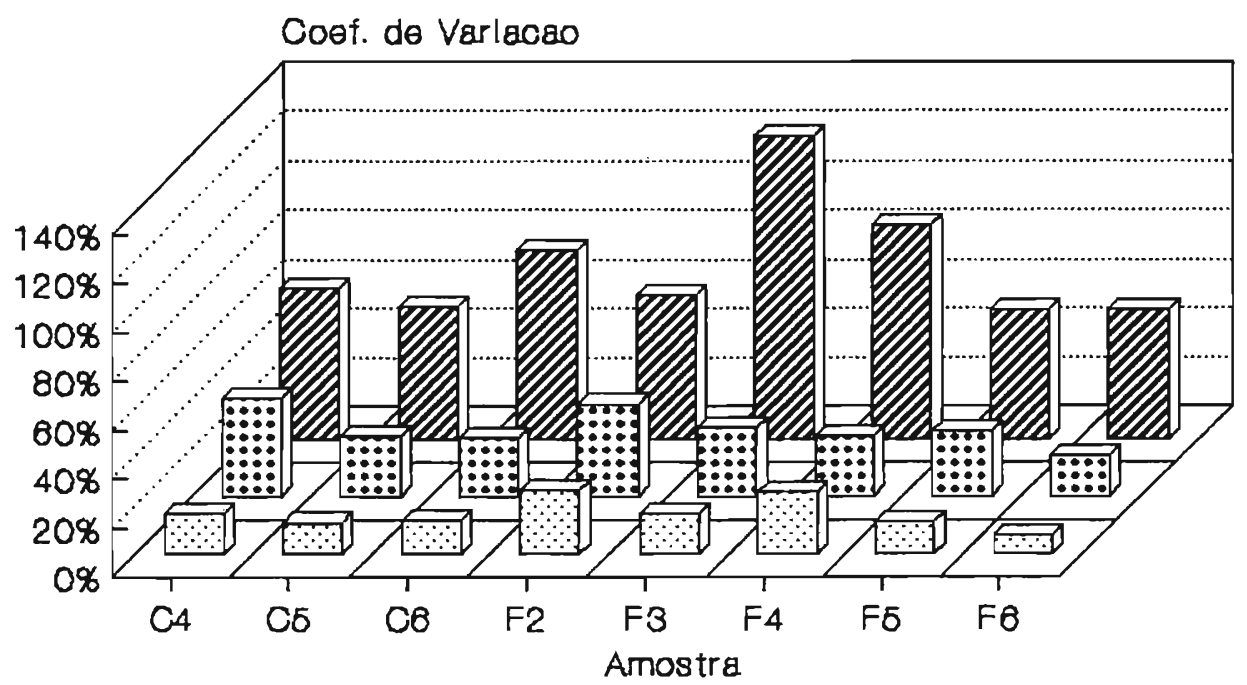

Método 4 Wi:i Método 3 Método 1 


\section{DISCUSSÃO}

\subsection{Considerações gerais}

A determinação do número de contaminantes microbianos viáveis em medicamentos não estéreis consta na Farmacopéia Brasileira ${ }^{74}$ como "método de contagem de microrganismos viáveis totais" e na USP XXII ${ }^{246}$, Farmacopéia Britânica 32 e na Alemã ${ }^{60}$ como "contagem total de microrganismos aeróbios".

Apesar da expressão "contagem total" ser amplamente empregada na microbiologia de medicamentos e cosméticos, é notória tal impropriedade, tendo em vista que os métodos analíticos envolvidos para essa finalidade apresentam limitações. Os microrganismos frequentemente presentes como contaminantes são de várias populações, com exigências nutricionais e condições de incubação diferentes.

Os métodos padrões, como os da American Public Health Association (APHA), empregam o termo "contagem padrão em placas" na avaliação microbiológica de alimentos e água, e fazem menção para que as determinações não sejam relatadas como "contagem total" 38.

Os métodos para determinação da carga microbiana contaminante em medicamentos não estéreis, constantes nas farmacopéias, são a contagem em placas por semeadura em profundidade ("pour-plate"), a filtração através de membrana e a contagem em meio líquido pelo Número Mais Provável (NMP). São os convencionalmente empregados na microbiologia tradicional, apenas introduzindo adaptação quanto à preparação da amostra, em função das suas características, principalmente quanto à atividade antimicrobiana 32,60,74,246. Sendo assim, a inconveniência desses recursos é o tempo requerido para a obtenção dos resultados, que é longo, por depender do tempo de incubação. Essa característica tem sido apontada como causa de limitação dos mesmos para o controle em processo ser mais efetivo, uma vez que os resultados obtidos são retroativos ${ }^{138}$. 
A filosofia de garantia de qualidade baseia-se na validação do processo para se obter produtos com carga microbiana dentro das especificações, e não no resultado imediato dos testes. Entretanto, mesmo com processos validados, a comprovação de que o produto está de acordo com as especificações é requerida para liberação do produto para a comercialização. As matérias-primas, mesmo aquelas provenientes de fornecedores com processos validados, são analisados para constatação de que estão dentro das especificações.

O tempo de quarentena da matéria-prima ou do produto acabado representa custo adicional no produto. Atualmente, com filosofias que preconizam demanda de estoque mínimo, os testes com obtenção de resultados mais rápidos é exigência para compatibilização com essas diretrizes.

Os ensaios físico-químicos, empregados no controle de qualidade de medicamentos e de cosméticos, evoluiram com o emprego de métodos instrumentais cada vez mais sofisticados, que permitem a obtenção de resultados em tempo cada vez menor. Por outro lado, apesar de os métodos de avaliação microbiológica convencionalmente ernpregados serem basicamente aqueles do início do século, alguns recursos alternativos mais rápidos foram desenvolvidos, visando sanar o problema anteriormente comentado. Analisando dados constantes na literatura verifica-se que esses apresentam limitações, impedindo sua aplicação a todos os tipos de amostras.

A contagem direta das células, após filtração e coloração diferencial, utilizando-se de microscópio de epifluorescência, é uma das técnicas mais difundidas. JARVIS e EASTER ${ }^{109}$ estimam em 20\% o emprego dessa técnica em substituição à contagem em placas, principalmente para determinação rápida da qualidade sanitária de leite cru e de carne. Entretanto, a aplicação desse método na rotina de controle de qualidade de medicamentos e cosméticos é ainda pouco difundida. A principal falha do método, alegada pelos analistas, na pesquisa efetuada por JARVIS e EASTER ${ }^{109}$, é a ineficiência na diferenciação entre células viáveis e não 
viáveis. Segundo LEECH $^{138}$, a baixa precisão desse método é decorrência de fallhas no treinamento de analistas $\theta$ assessoria dos fabricantes dos sistemas.

Os métodos automatizados que se baseiam no metabolismo das células não são aplicáveis para determinação quantitativa do número de microrganismos contaminantes. Como esses métodos não dependem somente da carga microbiana inicial mas também da velocidade de multiplicação dos microrganismos, o resultado obtido é qualitativo. Para obtenção do número de microrganismos inicialmente presentes, necessita-se conhecer o tempo de geração de cada cepa, pois o parâmetro de avaliação é o tempo requerido para o número original atingir o limite detectável pelo aparelho. Porém, esse dado não é previamente conhecido, uma vez que os contaminantes da amostra são desconhecidos ${ }^{138}$.

Esse método poderia ser empregado no teste para avaliação de eficiência de conservantes, tendo em vista que os microrganismos inoculados são conhecidos e assim permitir a determinação do tempo de geração dos mesmos. Por outro lado, esse tempo pode ser diferente quando se refere aos microrganismos debilitados pela presença do conservante, apresentando velocidade de multiplicação mais lenta.

Outras limitações desses métodos, mesmo para testes qualitativos, é a baixa sensibilidade. O tempo para obtenção de resultados será curto, desde que o número de microrganismos presentes seja elevado. Assim, para amostras com baixa carga microbiana o tempo necessário pode ser equivalente aos métodos tradicionais. Dependendo da natureza das amostras, para aplicação dos mesmos necessita-se de preparação prévia, que exige trabalho adicional, maior que o requerido pelas técnicas tradicionais.

Face as limitações de métodos alternativos, por serem pouco compatíveis com amostras com baixa carga microbiana, que é, geralmente, característica de medicamentos e cosméticos, na rotina de controle de qualidade desses produtos, os métodos microbiológicos tradicionais ainda são os mais 
empregados.

$\mathrm{Na}$ área de medicamentos, a restrição do uso de métodos alternativos deve-se, também, às especificações rígidas impostas por parte dos órgãos governamentais; para a substituição daqueles oficialmente adotados é necessária a comprovação de equivalência com os mesmos ${ }^{246}$. Todas as amostras de medicamentos e cosméticos podem ser analisadas por um dos métodos constantes nos códigos oficiais. Entretanto, produtos sob a forma de suspensão, de emulsão ou de sólidos que quando adicionados de diluentes aquosos resultam em sistema dispersos com partículas ou opacidade são aqueles que apresentam restrições na aplicação desses recursos analíticos.

Esse problema pode ser observado pelas medidas sugeridas ou empregadas quando da análise de amostras dessa natureza $36,100,173,174$.

BUHLMANN ${ }^{36}$, para possibilitar a aplicação do método de contagem em placas para produtos, que apresentam partículas ou opalescência na diluição correspondente a 1:10 e assim dificultando a visualização de colônias, sugere diluições mais altas. Esse recurso impede a análise de amostras com baixa carga microbiana, para cuja situação o autor recomenda a substituição do método quantitativo pelo qualitativo, inoculando-se a amostra em meio líquido.

Essa orientação foi adotada por HIRSCH e colaboradores ${ }^{100}$ na avaliação da qualidade microbiana de produtos para uso oral. O número de microrganismos contaminantes foi determinado para soluções, enquanto que as suspensões foram avaliadas apenas qualitativamente.

O método preconizado nos códigos oficiais para determinação de número de microrganismos em amostras com baixa carga microbiana é o método estimativo de diluição pelo número mais provável. Esse método, quando aplicado às amostras que resultam em turvação do meio, requer após incubação, a sub-cultura, o que exige, além de trabalho, tempo adicional de incubação para visualização do 
segundo crescimento. Para amostras dessa natureza, outro recurso proposto para detecção de microrganismos é o emprego de corantes de oxi-redução.

Corantes como o azul de metileno e resazurina são empregados nos testes de determinação do nível de contaminação em leite. Esses são compostos coloridos, que em presença de microrganismo, se tornam incolores. Inversamente, os sais de tetrazólio são incolores e quando reduzidos se tornam coloridos. A detecção macroscópica da presença de coloração em meio líquido é mais fácil que a diminuição de intensidade, situação devido principalmente ao número insuficiente de microrganismos, com isso não havendo nítida diferenciação.

O tempo para a redução total do azul de metileno, diluido de 1:250.000, somente ocorre em tempo menor que 6 horas, quando a carga bacteriana é maior que $2 \times 10^{5}$ organismos $/ \mathrm{mL}^{1}$.

A resazurina apresenta como desvantagem a dificuldade na diferenciação da coloração, pois a mudança é gradativa, passando de azul para violeta, rosa e finalmente incolor ${ }^{113,200}$.

Como recurso de auxlio para diferenciação de colônias, o cloreto de trifeniltetrazólio é mais adequado, pois a visualização de colônias vermelhas sobre fundo opalescente é mais fácil que a observação de pontos incolores no meio colorido.

A maior difusão do TTC para aplicação em determinação de microrganismos em relação aos outros sais de tetrazólio deve-se a menor toxidade desse frente aos outros ${ }^{150,233}$.

\subsection{Concentração mínima inibitória do cloreto de trifeniltetrazólio.}

O TTC foi adicionado aos meios de cultura, como recurso para identificação de microrganismos em amostras, tanto em meio líquido como sólido 93,106,110, Em vista disto, havia a necessidade da determinação da concentração mínima inibitória (MIC) deste corante, pois os contaminantes presentes nas amostras, 
ao ficarem em contacto direto com o mesmo adicionado ao meio de cultura em concentrações acima do MIC poderiam ser inibidos, conduzindo a resultado falso negativo.

As concentrações inibitórias do TTC foram determinadas para alguns microrganismos 106,150,163,165 233. Entretanto, os testes não foram padronizados quanto ao inóculo assim como quanto ao parâmetro de avaliação. Assim, TENGERDY e colaboradores ${ }^{233}$ por exemplo, utilizaram a inibição de $50 \%$ do inóculo de $10^{5}$ células após o contacto de 24 horas, ocasião em que foi efetuada a contagem dos sobreviventes. Os valores encontrados foram $100 \mu \mathrm{g} / \mathrm{mL}$ para $S$. aureus e 90 $\mu \mathrm{g} / \mathrm{mL}$ para $E$. coli. MAY e colaboradores 150 determinaram a dose mínima letal do corante, porém empregando 0,05 mL de cultura de 18 horas, como inóculo. Segundo o trabalho desses autores a concentração de $500 \mu \mathrm{g} / \mathrm{mL}$ não foi inibitória para bactérias Gram-negativas testadas, incluindo E. coli. Para B. subtilis e S. pyogenes o valor obtido foi de $32 \mu \mathrm{g} / \mathrm{mL}$. HURWITZ e MC CARTHY 106 relataram que a concentração mínima inibitória para $E$. coli foi de $2.759 \mu \mathrm{g} / \mathrm{mL}$ a $3.760 \mu \mathrm{g} / \mathrm{mL}$ quando o corante foi testado frente ao inóculo proveniente de cultura de uma noite, diluído para $10 \mathrm{~mL}$ de meio.

Através dos diversos valores de MIC relatados por esses trabalhos percebe-se que há discrepâncias em função das condições do teste. Como nos medicamentos e cosméticos a qualidade sanitária é variável quali e quantitativamente, torna-se necessária a avaliação da toxicidade do TTC frente à diferentes níveis de contaminação. Tendo em vista essa variável, neste trabalho o teste foi executado com inóculos de $10,10^{2}$ e $10^{3} \mathrm{UFC} / \mathrm{mL}$.

Entre as espécies Gram-negativas, a escolha recaiu sobre $E$. coli e $P$. aeruginosa por serem microrganismos específicos indesejáveis em medicamentos. O primeiro, em função da sua presença indicar condições inadequadas de higiene e o segundo, por ser um dos microrganismos Gram-negativos mais frequentemente isolado de medicamentos e cosméticos. Além disso, os microrganismos do gênero Pseudomonas estão relacionados à deterioração 13,21,134,207,210,256. 
Conforme os dados das Tabelas II a IV, os valores de concentração mínima inibitória (MIC) obtidos corroboram com aqueles determinados por outros autores $\mathbf{1 5 0 , 2 3 3}$.

Segundo os resultados de TENGERDY e colaboradores ${ }^{233}$ e MAY e colaboradores ${ }^{150}$, apesar de os valores de concentração mínima inibitória serem diferentes, o corante foi mais tóxico para bactérias Gram-positivas. Em função desse fato, no presente trabalho, o teste foi executado frente a maior número de espécies Gram-positivas.

Frente às concentrações testadas, apenas $S$. aureus acusou resistência, ao lado das 2 espécies Gram-negativas, com valor de MIC superior que a maior concentração testada $(120 \mu \mathrm{g} / \mathrm{mL})$. Este resultado é concordante com o de MAY e colaboradores ${ }^{150}$, pois esses verificaram que entre as bactérias Gram-positivas testadas, $S$. aureus apresentou maior resistência.

O M. flavus e o M. luteus foram aqueles que apresentaram maior sensibilidade, não se observando qualquer crescimento mesmo frente à concentração mínima testada (30 $\mu \mathrm{g} / \mathrm{mL}$ ). Quanto aos bacilos Gram-positivos observou-se inibição parcial em todas as concentrações testadas, detectada através de diminuição na intensidade de turvação, quando comparada ao crescimento no meio sem o TTC (Tabela III).

Sabe-se que o desenvolvimento da coloração depende do número de microrganismos presentes, mas também, da concentração do TTC adicionado ao meio ${ }^{258}$. Logo, o corante poderia ser utilizado em concentração abaixo do MIC desde que o mesmo fosse capaz de desenvolver coloração suficientemente intensa para permitir visualização macroscópica.

Pelos dados da Tabela IV referentes ao comportamento de bactérias Gram-negativas, a toxicidade do TTC não é o fator de restrição para o emprego do mesmo, pois a coloração é obtida em concentração que não inibe o 
crescimento. Entretanto, para bactérias Gram-positivas, considerando-se que 30 $\mu \mathrm{g} / \mathrm{mL}$ foi inibitório para estes microrganismos, a aplicação do corante somente seria válido, se o desenvolvimento de coloração ocorresse em concentrações menores que este valor. Pelos resultados obtidos (Tabela II) verifica-se que a concentração de 30 $\mu \mathrm{g} / \mathrm{mL}$ de TTC não promoveu o desenvolvimento de coloração macroscópicamente detectável, mesmo nos tubos que apresentaram turvação. Consequentemente, determinação mais precisa do valor de MIC para as bactérias Gram-positivas não foi de interesse, uma vez que é valor inferior que a menor testada.

\subsection{Influéncia da concentração de cloreto de trifeniltetrazólio, do inóculo e de aditivos ao meio de cultura no desenvolvimento da coloraçāo}

Os resultados obtidos na determinação da concentração mínima inibitória do TTC (Tabelas II a IV) mostraram que a adição do corante ao meio de cultura, juntamente com a amostra, com a finalidade de diminuir o tempo de incubação, na técnica de tubos múltiplos, não é viável. Este fato deve-se ao não aparecimento da coloração avermelhada, detectável à vista desarmada, quando a concentração do corante foi inferior ao de MIC, frente a alguns microrganismos.

Segundo vários autores, o TTC foi utilizado em concentrações muito acima do MIC para revelar viabilidade de organismos em culturas com elevada massa celular. Nessa condição a ação inibitória do corante sobre os microrganismos não interferiu no desenvolvimento do formazano $46,51,83,165$. Na literatura são citadas concentrações variando de 10 a $1.200 \mu \mathrm{g} / \mathrm{mL}$, para evidenciar o crescimento microbiano $51,106,139,165,219,233$.

A aplicação do TTC no método estimativo de tubos múltiplos implicaria na inoculação da amostra no meio de cultura convencional, com incubação até atingir número celular suficiente e posterior adição do corante, para desenvolvimento da coloração. Portanto, o tempo de incubação deverá ser suficiente 
para que a carga microbiana original atinja número detectável pela coloração.

A incubação da amostra antes da adição do corante é etapa que favorece o crescimento de microrganismos debilitados, pois esses são mais sensíveis à ação de substâncias tóxicas, necessitando de recuperação em meios sem agentes inibitórios. Essa prática é adotada na pesquisa de microrganismos específicos, em que a inoculação em meios contendo substâncias seletivas é efetuada após enriquecimento em meios não seletivos. Porém, o tempo de incubação poderia ser menor se a sensibilidade para detecção de crescimento através da coloração fosse maior que aquela baseada na turvação. Como a intensidade da coloração está diretamente relacionada ao número de microrganismos e, também, à velocidade de redução do TTC pelo microrganismo ${ }^{106,233}$, houve necessidade para a determinação do tempo de incubação em relação à carga microbiana inicial. Além disto, este inóculo não deve ser inibido pela concentração ideal do TTC, isto é, aquela com resposta macroscópica positiva.

Este estudo foi, também, direcionado para bactérias Grampositivas tendo em vista que são mais sensíveis à ação do $\Pi \mathrm{T}$ e segundo MAY e colaboradores ${ }^{150}$ a capacidade redutora do microrganismo está associada ao menor efeito letal. Entre os Gram-negativos o microrganismo de escolha foi $P$. aeruginosa pelas mesmas razões que justificaram a sua inclusão no teste de determinação de MIC.

Como naquele teste havia sido verificado que a concentração de $120 \mu \mathrm{g} / \mathrm{mL}$ não resultou em coloração intensa, para alguns microrganismos, mesmo após incubação de 72 horas, foram testadas $250,500,1.000$ e $2.000 \mu \mathrm{g} / \mathrm{mL}$.

Baseando no resultado de alguns pesquisadores ${ }^{16,219}$ quanto à adição de ácido glutâmico e de glicose ao meio de reação, neste trabalho foi efetuada a verificação da resposta do TTC frente a estes compostos, bem como polissorbato 20. O teste com o tensoativo foi pelo fato de ser sido relatado por CURRIER e DAY $\mathbf{5 1}$ que a alteração na permeabilidade da parede celular aumenta a velocidade de redução do TTC. Esses autores afirmaram ser os solventes apolares como o benzeno, 
responsáveis pela redução no tempo de reação. Entretanto, apresentam a inconveniência de toxicidade. Com relação à glicose e ácido glutâmico, SEVAG e FORBES 220 mostraram que a adição isolada não modificou a quantidade de formazano. Porém, a combinação desses resultou em aumento da redução de TTC. Entre as combinações testadas, aquela usando $1.000 \mu \mathrm{g} / \mathrm{mL}$ de ácido glutâmico foi a mais eficiente.

Neste trabalho a concentração de ácido glutâmico testada foi a mesma utilizada por esses autores. Quanto à glicose, decidiu-se por $0,5 \%$ baseado no trabalho de BARTLETT e MAZENS ${ }^{16}$ que verificaram o aumento de redução de TTC nas concentrações de 0,5 a 0,8\%. Esses detectaram a formação em maior nível, de formazano, na presença de glicose. Assim, houve a comparação entre o meio de cultura convencional e outros adicionados de ácido glutâmico, glicose e polissorbato 20.

Como segundo BIELG e colaboradores 22 o aumento de temperatura acelera a velocidade de redução do TTC pelos microrganismos, foram executados neste trabalho, testes prévios com incubação a $33 \pm 1^{\circ} \mathrm{C}$ e a temperatura ambiente. Os resultados comprovaram a observação relatada por aqueles autores, razão pela qual os tubos foram incubados em estufa após a inoculação dos meios e adição do corante, acompanhados durante 4 ou 20 horas para observar a manifestação da cor.

Pelos resultados configurados nas Tabelas $V$ a XIV verifica-se que para cada microrganismo em questão existe um sistema adequado, por sua vez relacionado ao inóculo e à concentração do TTC.

Quanto a observação macroscópica dos tubos, nos casos de reação positiva com coloração tênue ou no seu extremo, com a manifestação de vermelho intenso, por sua vez com tendência arroxeada ou rosada, houve dificuldades para a interpretação da resposta. 
Com relação a S. aureus, analisando comparativamente os sistemas 1, 2, 3 e 4, observa-se que a coloração máxima foi atingida a partir de 500 $\mu \mathrm{g} / \mathrm{mL}$, porém com intensidade menor na de $2.000 \mu \mathrm{g} / \mathrm{mL}$, indicando ter ocorrido parcial inibição. Este fato relaciona-se com a observação após 1 e 2 horas, havendo modificação quando decorridos 4 horas. 0 mesmo não pode ser dito para $P$. aeruginosa, pois, a concentração de $1.000 \mu \mathrm{g} / \mathrm{mL}$ correspondeu ao de máxima resposta; além disto, a maior concentração não apresentou ação inibitória, assim como a menor acusou intensidade igual aos demais quando decorridos 4 horas (Tabela VI).

Segundo JOHNSON e colaboradores ${ }^{114}$ o TTC é aplicável somente para detecção de organismos fermentadores porque os não fermentadores produzem quantidade muito pequena de substâncias redutoras, responsáveis pela produção de formazano. Entretanto, os resultados obtidos neste trabalho, em relação à $P$. aeruginosa, são discordantes. É bem verdade que a redução do corante ocorreu em menor intensidade que para outras bactérias, porém a resposta foi positiva.

Em vista destes resultados os outros microrganismos foram testados somente frente a concentração de 500 e $1.000 \mu \mathrm{g} / \mathrm{mL}$ de TTC. Para estes, conforme Tabelas VII a X, com exceção de $B$. subtilis, na primeira hora de reação, a coloração desenvolvida com $500 \mu \mathrm{g} / \mathrm{mL}$ foi macroscopicamente equivalente àquela com $1.000 \mu \mathrm{g} / \mathrm{mL}$ (sistemas 2=3). Este resultado, também, foi verificado por WEIBULL 258 para culturas de Bacillus megaterium, que resultou em coloração máxima com 500 $\mu \mathrm{g} / \mathrm{mL}$ após 1 hora de reação. Após 4 horas, entretanto, a coloração foi mais intensa em presença de maior concentração de TTC, exceto para $B$. subtilis que havia apresentado diferença nitidamente perceptível com $1.000 \mu \mathrm{g} / \mathrm{mL}$ na primeira hora; após 4 horas, o aumento da coloração não permitiu diferenciação entre as 2 concentrações.

Analisando os dados das Tabelas XI e XII, quando o inóculo foi de $10^{7} \mathrm{UFC} / \mathrm{mL}$, foi verificado ação inibitória do TTC sobre $S$. aureus, $S$. epidermidis, $M$. flavus e M. luteus. A coloração desenvolvida foi mais intensa nos meios com $500 \mu \mathrm{g} / \mathrm{mL}$ do que naquele com $1.000 \mu \mathrm{g} / \mathrm{mL}$, exceto para $B$. subtilis. Em relação a este 
microrganismo não foi possível a diferenciação de coloração nas duas concentrações do corante, indicando que $1.000 \mu \mathrm{g} / \mathrm{mL}$ não foi inibitória nas condições do teste.

Somente nos meios com $P$. aeruginosa com $10^{7} \mathrm{UFC} / \mathrm{mL}$ a intensidade de coloração foi proporcional à concentração do TTC, não se verificando inibição mesmo com $2.000 \mu \mathrm{g} / \mathrm{mL}$. Possivelmente, a resistência maior seja em função de ser este microrganismo uma bactéria Gram-negativa.

Inóculos com número menor de bactérias não apresentaram coloração visível, com 4 horas de incubação.

Segundo HURWITZ e MC CARTHY 106 o limite de sensibilidade determinado espectrofotometricamente, para E. coli com $500 \mu \mathrm{g} / \mathrm{mL}$ de $T T C$ e 4,5 horas de incubação foi de $10^{5}$ organismos $/ \mathrm{mL}$ Para os microrganismos testados, a visualização macroscópica foi possível somente com cargas 100 vezes maiores, no mesmo período de incubação (Tabelas XI e XII). MUSTAKALLO e colaboradores ${ }^{163}$, também, relataram que a coloração do formazano era detectável no leite em período inferior a 4,5 horas somente quando a carga contaminante era superior a $5 \times 10^{5}$ a $4 \mathrm{x}$ $10^{6} / \mathrm{mL}$

Visando melhor avaliação da ação do TTC frente a cargas menores, suspensões de $S$. aureus e $P$. aeruginosa que não desenvolveram coloração macroscopicamente detectável em 4 horas foram observadas após 20 horas (Tabelas XIII e XIV). Confirmando os dados anteriores para S. aureus, a concentração inibitória do TTC foi dependente da carga microbiana sendo estes valores menores que 500 $\mu \mathrm{g} / \mathrm{mL}$ para inóculo de $10^{5} \mathrm{UFC} / \mathrm{mL}$ e $1.000 \mu \mathrm{g} / \mathrm{mL}$ para $10^{6} \mathrm{UFC} / \mathrm{ml}$ (Tabela XIII). Em relação à $P$. aeruginosa (Tabela XIV) a coloração mais intensa foi obtida com 2.000 $\mu \mathrm{g} / \mathrm{mL}$. Para este microrganismo, a incubação promoveu, também, aumento da turvação do meio, indicando que o resultado obtido foi decorrente da multiplicação celular e não somente da redução do TTC no decorrer do tempo. 
glicose $\Theta \circ$ ácido glutâmico não promoveram o aumento na intensidade de coloração quando o inóculo foi de $10^{8} \mathrm{UFC} / \mathrm{mL}$ de $S$. aureus e de $P$. aeruginosa. Ao contrário, observou-se diminuição na maioria dos tubos. Em relação aos outros microrganismos Gram-positivos (Tabelas VII a X), apesar de não terem sido testados no meio padrão contendo somente estes componentes, pelo resultado obtido no meio contendo os 3 (sistemas 13 e 14), verifica-se que a presença adicional destes nutrientes diminuiu a intensidade de coloração quando comparado com os meios contendo somente o tensoativo (sistemas 6 e7), quando após 1 hora. Mesmo decorridas 4 horas o resultado foi praticamente igual.

A influência destes nutrientes sobre inóculos menores foi equivalente àquela obtida com inóculo de $10^{8} \mathrm{UFC} / \mathrm{mL}$ após incubações de 4 horas (Tabelas XI e XII).

Estes resultados são discordantes daqueles obtidos por SEVAG e FORBES ${ }^{219}$ que comprovaram aumento de até 30 vezes na intensidade de coloração, quando essas substâncias foram adicionadas ao meio de reação. Considerando-se que a redução do TTC é decorrente da ação de microrganismos em metabolismo, o aumento da coloração pela adição de glicose era fato esperado. Possivelmente, esta diferença seja decorrência da composição do meio em que a reação foi desenvolvida. Esses autores reportaram os resultados obtidos em solução tampão, enquanto neste trabalho foi empregado meio de cultura que contem nutrientes, inclusive glicose $\theta$ aminoácidos. FRED e KNIGHT ${ }^{83}$, também, não observaram aumento de redução de TTC com adição de glicose em suspensão de Penicillium chrysogenum, em tampão pH 7,2 .

Nas suspensões com elevadas carga microbiana que produzem formazano em quantidade perceptível em 1 hora, a influência do polissorbato 20 não foi o mesmo para todos os microrganismos testados. Para M. flavus (Tabela VIII) e B. subtilis (Tabela $\mathrm{X}$ ) a intensidade de coloração desenvolvida no meio com o tensoativo foi maior, enquanto para outros microrganismos foi menos intensa quando comparado 
ao meio de cultura sem polissorbato (Tabelas V, VI, VII e IX). Entretanto, após 4 horas, para todos os microrganismos, o desenvolvimento da coloração foi mais intensa, com exceção de $M$. luteus. Conforme os dados da Tabela XXXI, posteriormente foi verificado que o polissorbato 20 inibe este microrganismo, fato que pode explicar o resultado obtido.

Para inóculo de $10^{7} / \mathrm{mL}$, após incubação de 4 horas, o polissorbato promoveu o aumento de coloração para todos os microrganismos, com exceção de $P$. aeruginosa (Tabela XI) e M. luteus (Tabela XII). Nos meios com cargas menores de $S$. aureus (Tabela XIII) e $P$. aeruginosa (Tabela XIV) após 20 horas, a coloração foi mais intensa nos meios contendo o tensoativo.

A redução do TTC para formazano ocorre no interior da célula, com retenção do corante insolúvel 162, 258. A presença de polissorbato 20 acusou, sempre, coloração vermelha, tanto das células como do meio de cultura.

MERKEL e NICKERSON 157 observaram o mesmo efeito com a adição de cianeto de potássio ou sal dissódico do ácido etilenodiamina tetracético. Segundo esses autores, o mecanismo envolvido é a complexação de metais por esses compostos, que removem barreiras da parede celular, dependentes de metais. Reforça essa teoria o fato que outros complexantes como oxalato de sódio e dietilditiocarbamato de sódio apresentaram as mesmas propriedades.

No caso de polissorbato 20 , possivelmente a difusão do formazano, que é pouco solúvel em água, ocorre pela alteração da permeabilidade da parede celular, por ser este composto um tensoativo.

Quando o TTC é adicionado na suspensão de microrganismos, no início da reação, o acúmulo do corante reduzido no interior da célula facilita visualização da coloração. Entretanto, quando a quantidade de formazano produzido atinge nível mais elevado, a difusão do mesmo para o meio de cultura intensifica a coloração. Isto ocorre porque o meio de cultura torna-se colorido homogeneamente, 
enquanto no meio convencional a coloração é resultado de células coloridas em suspensão.

Quando a massa celular é pequena, a quantidade de formazano produzido é menor, e a difusão para o meio de cultura altera apenas levemente a tonalidade do meio de cultura, e como o próprio meio apresenta coloração amarela, a mudança para o alaranjado, dependendo da intensidade não é facilmente detectada.

Os resultados dos testes para verificar a influência dos nutrientes e do polissorbato na redução do TTC para formazano não foram precisos em função do parâmetro de medida que foi a observação visual comparativa sem utilização de instrumento.

HURWITZ e MC CARTHY ${ }^{106}$, após desenvolvimento da coloração determinaram a concentração do formazano por meio de leitura de absorbância do corante extraído com butanona. Esse método é mais preciso, porém não foi aplicado neste estudo, pois não havia interesse na diferenciação de intensidade de coloração, uma vez que a avaliação no teste de determinação da carga microbiana o recurso empregado é observação visual. Não foram efetuados outros testes mais precisos, pois verificou-se que a adição destes compostos não aumentou a intensidade de coloração, à níveis que possibilitassem a redução do tempo para detecção da coloração macroscopicamente visível. Este recurso também não possibilitou a redução do corante à níveis visualmente detectáveis com inóculos de baixa carga microbiana, em tempo menor que 4 horas.

Frente aos resultados obtidos, verificou-se que a aplicação do TTC como recurso para diminuir o tempo de incubação não é viável, pois a detecção da presença de carga microbiana, por meio de desenvolvimento de coloração, não é mais sensível que aquela que se baseia na turvação. 


\subsection{Comparação entre a técnica de tubos múltiplos com sub-cultura e emprego de cloreto de trifeniltetrazólio na detecçáo de microrganismos.}

A redução do TTC com produção de formazano em quantidade macroscopicamente visível, em tempo inferior a 4 horas, ocorre somente em presença de elevada carga microbiana. A baixa sensibilidade deste recurso alternativo não justifica a sua aplicação na detecção de microrganismos nos meios em que a turvação decorrente da presença de massa celular pode ser facilmente visualizada. Consequentemente, o uso de TTC no teste de contagem de microrganismos, em amostras solúveis em meio aquoso, não apresenta vantagens, tendo em vista que a coloração é macroscopicamente visualizada quando a massa celular pode ser detectada pela turvação.

Nas amostras que resultam em sistemas com turvação quando inoculadas em meio de cultura líquido, o emprego do TTC para visualização de massa celular pode representar redução de tempo gasto, se a detecção de microrganismos por meio deste recurso for equivalente em precisão à sub-cultura, que é o método de detecção tradicionalmente empregado.

Neste estudo, além de bactérias, as leveduras foram incluídas, pois a massa celular resultante do crescimento destes microrganismos em meio líquido, também, não pode ser detectada diretamente pela observação à vista desarmada em sistemas bifásicos. O mesmo problema não ocorre com bolores normalmente encontrados como contaminantes em medicamentos e cosméticos.

O teste foi executado com suspensão de bactérias contendo 100 UFC $/ \mathrm{mL}$. As leveduras foram testadas com 100 e $10 \mathrm{UFC} / \mathrm{mL}$. A suspensão mais diluída foi empregada considerando-se que padrões microbianos são mais rígidos para bolores e leveduras que para bactérias 47,62 . 
a adição do TTC, após curtos períodos de incubação, não é eficiente, uma vez que a coloração se desenvolveu somente em meios com alta carga bacteriana. Tendo em vista estes resultados, a adição do corante e a sub-cultura foram efetuadas após incubação de 20 horas para as bactérias e 72 horas para as leveduras, visando assegurar presença suficiente de massa celular para o desenvolvimento da coloração.

A avaliação foi efetuada nos meios padrões e também nos mesmos contendo polissorbato 20 e lecitina, pois a adição de tensoativos no meio de cultura é recurso utilizado, visando neutralização de conservantes, quando a amostra é semeada sem diluição prévia. Este recurso é empregado nestes casos, porque a carga microbiana estimada é baixa e não permite a diluição da amostra com fluidos contendo neutralizantes.

Pelos dados configurados nas Tabelas XV a XVII e XIX a XXI verifica-se que a turvação obtida nos meios com os tensoativos foi menos intensa quando comparada com aquela observada no meio de caseína-soja para as bactérias Gram-positivas, com exceção de S. aureus e S. epidermidis.

A inibição foi mais acentuada nos tubos contendo menor carga microbiana e no caso de $M$. luteus a inibição foi total, não se observando turvação.

Apesar de MAY e colaboradores ${ }^{150}$ terem relatado que bactérias Gram-positivas são mais sensíveis aos agentes tensoativos, foi efetuado teste adicional com S. aureus, $S$. epidermidis e $M$. luteus nos meios contendo os tensoativos isoladamente e lecitina, visando a confirmação da atividade inibitória dos mesmos frente à estes germes.

Pelos resultados da Tabela $X X X \mid$ verifica-se que os tensoativos testados não afetaram o crescimento de $S$. aureus, mesmo quando em presença de inóculo muito pequeno, da ordem de $1 \mathrm{UFC} / \mathrm{mL}$. Entretanto, em relação às outras bactérias testadas, confirmou a inibição verificada no teste 4.2.12 (Tabelas XVI e XX).

A atividade dos polissorbatos foi mais acentuada para $M$. luteus. 
Estes tensoativos quando testados frente ao inóculo de $10^{2} \mathrm{UFC} / \mathrm{mL}$, o número de tubos com turvação foi igual em todos os meios testados, apesar da intensidade de turvação ter sido menor naqueles contendo os mesmos, indicando presença de efeito inibitório parcial. Este efeito foi confirmado quando a carga inoculada foi 10 vezes menor. Este comportamento foi observado quando o tempo de incubação foi de 20 a 24 horas, enquanto que com 48 horas houve resultado diferente, indicando que a ação dos tensoativos não é biocida, pois a fração positiva apresentou evidências de que não há diferenças (Tabelas $X X X \mathrm{I}$ ). Pelos dados obtidos neste teste a adição de polissorbatos 80 e 20 e da lecitina nos meios de cultura não influi no resultado final, desde que o tempo de incubação seja suficientemente longo. Por outro lado, sabe-se que as condições do teste podem não reproduzir as reais de uma contagem em amostras, pois os microrganismos empregados foram aqueles provenientes de culturas puras e jovens, enquanto os contaminantes, por se encontrarem, muitas vezes, debilitados serem irreversivelmente inibidos. Consequentemente, a adição destes compostos diretamente no meio de cultura deve ser evitada quando se dispõe de outro recurso.

O TTC foi testado nas concentrações de 500 e $1.000 \mu \mathrm{g} / \mathrm{mL}$, tendo em vista que resultados anteriores mostraram coloração máxima com uma ou outra concentração, dependendo do microrganismo e do tempo de observação, após adição do corante.

Nos tubos em que a turvação foi intensa o desenvolvimento da coloração ocorreu rapidamente, em períodos inferiores a 15 minutos. Entretanto, nos meios com leve turvação a mudança da coloração macroscopicamente visível não foi tão rápida. Tendo em vista o segundo caso, foi estabelecido o tempo de 1 hora após adição do corante para se efetuar a primeira observação.

Conforme os dados constantes na Tabelas XV a XXII, todos os microrganismos testados, com exceção de $M$. luteus e $S$. aureus desenvolveram coloração visível em todos os tubos que continham o inóculo mais concentrado (10 2 
UFC/tubo), após 1 hora da adição do TTC. É bem verdade que a turvação obtida no teste original, com 20 horas de incubação de $M$. luteus foi pouco intensa mesmo com este inóculo, resultando consequentemente em ausência ou presença de coloração muito clara. Todos os tubos inoculados com cargas 10 vezes menores, que apresentaram turvação, também, se tornaram coloridos, com exceção de alguns tubos contendo $S$. aureus, $M$. luteus e $P$. aeruginosa. Estranhamente, 1 tubo com inóculo de $10^{2}$ UFC/tubo e outro com 10 UFC/tubo de S. aureus, aparentemente com intensidade de turvação equivalente aos demais que se apresentaram coloridos, não reduziram o TTC à níveis macroscopicamente visíveis, em 1 hora. Após 2 horas aquele com inóculo menor tornou-se rosado, entretanto no meio com o inóculo mais concentrado o formazano foi detectado somente na observação efetuada 18 horas após a adição do TTC (Tabela XIX).

Neste ensaio o parâmetro de detecção de células viáveis pelo TTC, com 1 hora de contacto, foi comparado ao da sub-cultura com incubação de 18 horas, sendo que os tubos que não apresentaram turvação nesse período foram reincubados até 48 horas, a fim de proceder à confirmação do resultado.

A equivalência do número de tubos com crescimento detectado pelo TTC em relação à sub-cultura foi obtida apenas para $E$. coli nas 2 concentrações do corante (Tabela XXIII). Este resultado é justificado pela turvação que foi intensa em todos os tubos, mesmo naqueles inoculados com baixa carga bacteriana.

O mesmo resultado foi constatado para $S$. aureus e $M$. flavus, na concentração de $500 \mu \mathrm{g} / \mathrm{mL}$ de TTC (Tabela XXIII). Na presença de dobro de concentração do corante o número de tubos com crescimento detectado pela subcultura foi maior, ainda que a diferença tenha sido de apenas 1 tubo para os 2 microrganismos.

A correspondência entre os 2 parâmetros não foi obsenvada quando o inóculo foi de 1 UFC/tubo ou menor. Entretanto, com exceção de alguns tubos com $P$. aeruginosa (Tabelas XVIII e XXII), desde que 0 meio apresentasse 
turvação, a adição de TTC promoveu o desenvolvimento de coloração em 1 hora, e alguns, mesmo sem turvação, tornaram-se rosados.

Quando avaliados pela observação de 3 horas após a adição do corante, a correspondência entre os 2 métodos de detecção foi maior do que aquela obtida com observação de 1 hora. Para todas as bactérias testadas, com exceção de $P$. aeruginosa $\Theta M$. luteus, o número de tubos com crescimento detectado pelo TTC na concentração de $500 \mu \mathrm{g} / \mathrm{mL}$ foi o mesmo daquele obtido pela sub-cultura, enquanto com $1.000 \mu \mathrm{g} / \mathrm{mL}$ esta correspondência foi observada somente para E. coli, M. flavus e B. pumilus (Tabela XXIII).

O resultado obtido para $P$. aeruginosa poderia ser justificado pelo relato de JOHNSON e colaboradores ${ }^{114}$. No entanto, essa afirmação é contestável, considerando-se que após 1 hora a coloração foi visualizada nos tubos com turvação. É verdade que a intensidade de coloração obtida foi menor quando comparada, por exemplo, com aquela observada nos tubos com E. coli, porém a intensidade de turvação foi também, menor. Baseado no relato daqueles autores ${ }^{\mathbf{1 1 4}}$, pode-se supor que a quantidade de substâncias redutoras de $P$. aeruginosa sendo menor tenha sido parcialmente responsável por este resultado, porém a causa parece ser também a insuficiência do tempo de incubação, uma vez que os 2 tubos que não desenvolveram coloração tinham sido inoculados com baixa carga microbiana (10 e 1 UFC/tubo) (Tabelas XVIII e XXII).

Resultado semelhante foi observado por BARTLETT e MAZENS 15 no teste para determinação de MIC empregando-se iodonitrofeniltetrazólio como agente revelador do crescimento de $P$. aeruginosa e Acinetobacter sp. Para os 2 microrganismos foi necessário inóculo de $10^{8} \mathrm{UFC} / \mathrm{mL}$, número 10 vezes maior que aquele de outros microrganismos.

Portanto, o TTC pode ser empregado para revelação de bactérias não fermentadoras desde que o tempo de incubação seja suficiente para se ter número adequado de células. 
Os resultados obtidos indicam que o período de incubação de 20 horas não é suficiente para a detecção de algumas bactérias, quando é inoculada baixa carga. Entre as bactérias testadas, além de $P$. aeruginosa, o $M$. luteus também não resultou em massa celular suficiente para o desenvolvimento de coloração, mesmo após incubação de 18 horas com o corante. Reforça esta conclusão, o resultado obtido com $M$. luteus, que mesmo a sub-cultura com incubação de 18 horas não detectou a presença do mesmo em alguns tubos, necessitando de 48 horas para o desenvolvimento de turvação. Estes dados conflitam com aqueles relatados por JOHNSON e colaboradores ${ }^{34}$. Esses afirmaram ser 4 horas de incubação suficientes para que 0 inóculo de $10 \mathrm{UFC} / \mathrm{mL}$ atingisse carga detectável pelo TTC. Porém, BARTLEIT e MAZENS ${ }^{3}$ verificaram ser necessário inóculo da ordem de $10^{7}$ a $10^{8}$ UFC/mL para o mesmo tipo de resposta.

A adição de TTC em concentração de $1.000 \mathrm{~g} / \mathrm{mL}$ (Tabelas XIX a XXII) resultou em maior intensidade de coloração para alguns tubos contendo $P$. aeruginosa, B. subtilis, S. epidermidis e S. aureus. Entretanto, essa concentração não promoveu o aumento no número de tubos com microrganismos detectados pelo corante, quando comparado àqueles obtidos com $500 \mu \mathrm{g} / \mathrm{mL}$ (Tabela XXIII).

A presença de polissorbato 20 no meio de cultura aumentou a intensidade de coloração. A adição desta substância poderia ser adotada com objetivo de facilitar a visualização da coloração. Porém, a sua atividade biostática frente a algumas bactérias como $M$. luteus, verificado pelo teste 4.2 .14 (Tabela XXXI) não justifica a inclusão do mesmo para esta finalidade, pois quando a massa celular é elevada, a coloração desenvolvida é suficientemente intensa permitindo fácil visualização.

O tempo necessário para a leitura de resultados, quando se empregou o método alternativo pelo $T \mathrm{TC}$ com $500 \mu \mathrm{g} / \mathrm{mL}$, foi menor que aquele requerido pela sub-cultura, pois, para todas as bactérias testadas, exceto $P$. aeruginosa e M. luteus, foi possível com cerca de 23 horas, considerando-se a leitura após 3 horas 
da adição do corante. Porém, o dado com sub-cultura de 5 horas, perfazendo o total de 25 horas de análise, perrnitiu equivalência somente para E. coli e B. subtilis (Tabela XXIII). Desta forma, pelo menos para a maioria dos microrganismos testados, o ternpo envolvido, para obtenção de resultado, pelo método alternativo foi menor que o convencional.

Nos meios inoculados com pequena carga de $P$. aeruginosa a subcultura com incubação de 18 horas mostrou-se mais eficiente que o TTC, uma vez que todos os tubos com crescimento foram detectados neste período de tempo, enquanto que em alguns, o meio não se coloriu na presença do corante. Por outro lado, para $M$. luteus, apesar de a sub-cultura ter detectado maior número de tubos com resposta positiva que o TTC, o período de 18 horas, também, não foi suficiente, pois alguns se tornaram turvos após 48 horas de incubação.

Como foi mencionado anteriormente, para algumas bactérias a incubação por 20 horas não é suficiente para promover aumento da carga microbiana a nível detectável pelo TTC, quando o inóculo é pequeno.

A incubação dos tubos inoculados com a amostra durante 48 horas, para posterior adição do corante, proporcionaria maior segurança nos casos de amostras com baixa carga microbiana em que a velocidade de multiplicação dos contaminantes não é suficiente para atingir número detectável pelo TTC, em 20 horas. Mesmo considerando esse tempo adicional de incubação, o método alternativo é mais rápido, se comparado ao de sub-cultura com incubação de 48 horas, tempo necessário para algumas bactérias, como foi verificado para $M$. luteus. Estes cuidados são fundamentais, uma vez que na análise de amostras não se conhecem os microrganismos contaminantes e seu número.

Em relação às leveduras, o comportamento das mesmas foi diferente frente ao TTC (Tabelas XXIV a XXVII). Para as 2 cepas de $S$. cerevisiae, a avaliação baseada na incubação de 72 horas, seguida de adição do corante e observação da coloração após 1 hora foi eficiente, somente para inóculos com cargas 
de $10^{2}$ e $10 \mathrm{UFC} /$ tubo. Alguns tubos com 1 e $0,1 \mathrm{UFC} /$ tubo tornaram-se coloridos após 4 horas, enquanto que aqueles com carga 10 vezes menor necessitaram de 18 horas. Por outro lado, a sub-cultura com incubação inferior a 48 horas, também, não foi eficiente, para todos os níveis de inóculo. Alguns tubos com nítida turvação, que acusaram resposta positiva com TTC após 1 hora de contato necessitaram de 24 a 48 horas quando avaliados pela sub-cultura.

A comparação entre o número de tubos detectados pela coloração após 1 hora e 0 da sub-cultura com incubação de 24 horas mostra que o método alternativo foi mais eficiente (Tabelas XXVIII e XXIX). Porém, quando o inóculo foi pequeno, o método da sub-cultura foi superior, desde que o tempo de incubação dos tubos tenha sido de 48 horas. Esta eficiência foi mantida mesmo frente ao teste com a leitura da reação de redução do TTC após 18 horas.

Pelos dados obtidos (Tabelas XXV e XXVI) verifica-se que o tempo de incubação de 72 horas não foi suficiente para que inóculos de 1 a 0,1 UFC/tubo, atinjam quantidade de massa celular detectável pelo TTC, após contacto de 1 a 4 horas. A sub-cultura com incubação de 24 horas, também, não foi eficiente, necessitando de 48 horas.

A detecção de $S$. cerevisiae com TTC, apesar de não fornecer resultados coerentes com o de sub-cultura com 48 horas de incubação para inóculos com baixa carga, permite efetuar a leitura em 1 hora desde que a massa celular seja elevada (Tabelas XXIV a XXVII). Portanto, apresenta vantagem em relação à técnica de sub-cultura que pode requerer até 48 horas de incubação.

No caso de 2 cepas de S. cerevisiae, quando o teste foi executado com a suspensão de $10 \mathrm{UFC} / \mathrm{mL}$, aqueles tubos contendo inóculo baixo, da ordem de 0,1 UFC/tubo, foi observado após reincubação dos mesmos por mais 24 horas. Desta forma, alguns tubos anteriormente límpidos passaram a apresentar turvação, os quais foram, também, positivados pelo TTC (Tabelas XXV e XXVII). 
A eficiência na detecção destas leveduras pelo TTC não acusou diferenças, se com a concentração de 500 ou $1.000 \mu \mathrm{g} / \mathrm{mL}$ Empregando-se tanto uma como a outra concentração a equivalência com a sub-cultura de 48 horas de incubação não foi obtida (Tabelas XXVIII e XXIX).

Logo, a opção para maior segurança nos resultados será aumentar 0 tempo de incubação dos tubos originalmente inoculados para em seguida aplicar o teste alternativo, cuja resposta pode ser obtida dentro de 1 hora. Assim, diminuiria o tempo adicional de 48 horas correspondente à sub-cultura.

A reação de C. albicans com TTC não foi a mesma observada para S. cerevisiae. Os tubos com meio de Sabouraud-dextrose (M3) com turvação desenvolveram coloração rosa no período de 1 hora após a adição do corante, porém, sem a intensificação da coloração mesmo após 18 horas. Nos tubos contendo meio adicionado de tensoativos não houve desenvolvimento de coloração, apesar da presença de massa celular, visualizada pela turvação.

A redução do TTC pelos microrganismos é dependente do $\mathrm{pH}$, sendo a faixa mais favorável de 7,0 a $7,6^{33,51,83,156}$. Neste trabalho o meio de caseínasoja (M1) não foi neutralizado após incubação com os microrganismos considerandose que o sistema tamponante do próprio meio manteria o pH próximo à neutralidade. $\mathrm{A}$ adequacidade deste procedimento foi confirmado pela redução obtida mesmo com culturas de $E$. coli, pois houve formação de intensa coloração vermelha. LEDERBERG 137 e LISKA e colaboradores ${ }^{140}$ relataram que cepas de E. coli não reduzem o TTC em função pH ácido do meio decorrente da fermentação de carboidratos.

Segundo BRODIE e GOTS ${ }^{33}$ a faixa de valores de $\mathrm{pH}$ de maior redução para leveduras situa-se entre 7,5 a 8,3, cessando completamente quando o pH do meio atingir valores de 6,9 ou 9,2. FRED e KNIGHT ${ }^{85}$, também, relataram que a redução do TTC pelos micélios de Penicillium chrysogenum foi retardado em pH abaixo de 7,2 e não se observou qualquer coloração em pH 6,0. 
O pH do caldo Sabouraud-dextrose (M3) é de $5,6 \pm 0,2$, meio considerado impróprio para redução de TTC. Apesar disto, a redução do corante pelo S. cerevisiae foi intensa mesmo sem a correção do pH para a neutralidade.

O dado encontrado para $C$. albicans não confirma aquele verificado por RIOUX e colaboradores ${ }^{209}$, que relataram serem brancas as colónias dessa espécie em meio com TTC, constituindo caracteristica de diferenciação em relação a outras espécies do gênero que adquirem coloração rósea Esse resultado pode ter sido em função das condições empregadas, pois eles usaram $100 \mu \mathrm{g} / \mathrm{mL}$ do corante em meio sólido.

Apesar do desenvolvimento da coloração em caldo Sabourauddextrose, sua intensidade foi mais clara que aquela manifestada pelos outros microrganismos, e na presença de tensoativos a reação foi negativa, como pode ser visto pelos dados das Tabelas XXIV e XXV.

Face aos dados observados, a C. albicans foi testada frente à concentrações maiores de TTC, com e sem neutralização do meio de cultura. A solução de hidróxido de sódio $2 \mathrm{~N}$ foi adicionado após a incubação, e o volume empregado foi estabelecido por testes prévios para atingir o pH próximo de 7,5.

A avaliação foi efetuada após 2 horas da adição do TTC pois após 1 hora os tubos contendo meio com tensoativo se apresentaram apenas levemente coloridos.

Pelos dados da Tabela XXX verifica-se que com o aumento da concentração de TTC a coloração se tornou mais intensa. A concentração de 1.000 $\mu \mathrm{g} / \mathrm{mL}$ do corante não foi suficiente, pois em alguns tubos não se verificou coloração, mesmo no meio de Sabouraud-dextrose neutralizado. Na presença de polissorbato 20 o corante teve que ser aumentado até $2.500 \mu \mathrm{g} / \mathrm{mL}$ e mesmo assim a coloração foi levemente avermelhada em pH ácido. A neutralização do meio provocou o aumento da intensidade de coloração em todos os tubos. A detecção do crescimento empregando- 
se esta concentração de TTC foi de total correspondência com a sub-cultura de 48 horas, confirmando a conclusão de outros pesquisadores ${ }^{33,83}$.

O uso de concentração cada vez maior do corante defronta-se com problemas inerentes à toxicidade. As concentrações de TTC superiores a 1.000 $\mu \mathrm{g} / \mathrm{mL}$ foram relatadas como sendo inibitória para algumas bactérias ${ }^{163,165,253}$. Para C. albicans, a coloração foi mais intensa com $5.000 \mu \mathrm{g} / \mathrm{mL}$ não se verificando essa ação do corante. Este resultado pode ser dependente da maior ou menor sensibilidade da levedura e também da elevada carga presente. Apesar desta relação direta entre a intensidade de cor $\theta$ aumento da concentração do corante, desde que com 2.500 $\mu \mathrm{g} / \mathrm{mL}$ já se obteve dado equivalente ao da sub-cultura, esta poderá ser empregada para a determinação da carga contaminante leveduriforme.

\subsection{Determinação da concentração mínima eficaz de cloreto de trifeniltetrazólio para revelação de colónia bacterianas e de leveduras}

A aplicação do TTC, como recurso para diferenciação de colónias de outros materiais ou para facilitar a visualização das mesmas em meios com opacidade, foi proposta por alguns autores $38,110,254$. Esses sugeriram a adição do corante no meio de cultura empregado. Entretanto, o problema desse método, como foi anteriormente comentado, é que muitas bactérias podem ser inibidas na sua

presença 150,233 . Além disso, quando se trata de método de "pour-plate" a temperatura do meio fundido acentua a agressividade dos agentes seletivos principalmente para os microrganismos debilitados 205.

BUSTA e colaboradores ${ }^{38}$, frente a essa possibilidade, recomendou efetuar, inicialmente, a contagem dos contaminantes no meio com e sem adição de TTC, para varificar a existência de qualquer efeito deletéreo do corante sobre os microrganismos presentes. Todavia, essa recomendação não procede, uma vez que a inclusão do TTC no meio de cultura tem a finalidade de justamente permitir a visualização de colônias em amostras que apresentam dificuldades para sua detecção. 
Se a contagem é possivel sem a utilização do corante, não se justifica a sua inclusão.

GOSHKO ${ }^{93}$, também, considerando a toxicidade do TTC, questionou a validade desse método e estudou os efeitos da adição do corante no meio, nas concentrações geralmente recomendadas, de 50 a $100 \mu \mathrm{g} / \mathrm{mL}$, para se testar amostras de matérias-primas insolúveis de uso farmacêutico. Segundo o mesmo, a inclusão do TTC facilitou o reconhecimento de colônias, reduzindo o tempo para a leitura de cada amostra, passando de 2 minutos para 30 segundos, além de dispensar o emprego de recurso de aumento para a contagem das mesmas. Entretanto, ao lado dessa vantagem, esse pesquisador verificou a inibição de bactérias no meio com o corante, pois o número de colónias foi significativamente menor quando comparado à contagem em meio convencional.

Neste trabalho, optou-se pela incubação da amostra juntamente com o meio de cultuta, sem o corante, para posterior adição do TTC, visando a eliminação do efeito inibitório que poderia falsear o número de colônias. Esse procedimento foi empregado por CODY e colaboradores ${ }^{\mathbf{4 4}}$ na contagem de $E$. coli, diretamente em lençóis de hospitais. Esses autores colocaram a solução aquosa de TTC a $0,1 \%$ nas placas sobre a superfície do meio de cultura.

No presente trabalho, O TTC não foi aplicado na forma de solução aquosa, pois pelos testes prévios se verificou que este procedimento provocava a desagregação das colônias situadas na superfície do meio, introduzindo erro de contagem. Decidiu-se, então, pela adição do TTC incorporado no gel com 1,0\% de ágar fundido e resfriado até cerca de $48^{\circ} \mathrm{C}$, preparado conforme descrito no item 4.2.2. Esta técnica, também, foi empregada por WOODS e SMITH ${ }^{262}$ para detecção de colônias de Mycoplasma pneumoniae.

Quando O TTC, juntamente com ágar é depositado sobre a superfície do meio de cultura, a coloração das colônias localizadas no interior deste dependerá da difusão do corante em toda a profundidade do gel e contato com as células microbianas a fim de desencadear a reação. 
A difusão de uma substância no ágar por sua vez depende da sua concentração, da área de contato, da viscosidade do sistema, da temperatura, do tempo envolvido, etc. ${ }^{48}$. Consequentemente, fatores como espessura e temperatura do meio de cultura, além do tempo após adição do corante, vão influir na coloração das colónias presentes. Evidentemente, que a espessura do meio de cultura contido na placa, de determinado diâmetro, está diretamente relacionada ao volume transferido para a mesma. Neste trabalho, a determinação da concentração mínima eficaz para a revelação de colónias foi efetuada frente a volumes de 15 e $20 \mathrm{~mL}$, em placas de Petri com $10 \mathrm{~cm}$ de diâmetro por serem parâmetros normalmente recomendados nos métodos de contagem de microrganismos viáveis pela técnica de semeadura em profundidade.

Como foi mencionado anteriormente, o aumento da temperatura acelera a redução do TTC pelos microrganismos. No método utilizado, neste trabalho, a incubação a temperatura de $33 \pm 1^{\circ} \mathrm{C}$ é duplamente favorável à coloração da colônias, pois o calor além de aumentar a atividade redutora dos microrganismos, também, aumenta a difusão do corante no ágar ${ }^{48}$.

Conforme os dados da Tabela XXXII, referentes às bactérias, observa-se nítida relação entre os vários parâmetros anteriormente comentados. A coloração das colônias situadas na superfície ocorreu no período de 15 minutos, mesmo com a concentração de $0,025 \%$ do corante. Este dado justifica-se pelo fato de que a produção de formazano é quase imediata, uma vez que o corante entra em contacto com a massa bacteriana tão logo o gel é adicionado na superfície do meio, sendo a coloração dependente somente da velocidade de redução do TTC pelo microrganismo. Comparando esta situação com a mesma reação no meio líquido, pode-se dizer que no caso de colônias a visualização da reação é melhor e mais rápida pelo fato de haver concentração de células num determinado ponto e consequentemente o formazano resultante. No caso de suspensão microbiana, embora o número fosse igual ou superior ao das colônias, este é disperso em todo volume do meio. 
A coloração das colónias localizadas na profundidade foi dependente da concentração do TTC e do volume de meio de cultura empregado, confirmando o esperado. Portanto, a coloração destas colônias em menor tempo foi obtida com a concentração de $0,2 \%$ do $T T C$ e $15 \mathrm{~mL}$ do meio de cultura. Esta combinação permitiu a coloração de todas as colónias presentes na placa em 30 minutos de reação. Entretanto, o aumento do volume para $20 \mathrm{~mL}$ aumentou, também, o tempo de leitura para 60 minutos.

Após 60 minutos de reação, todas as colônias se tornaram vermelhas mesmo aquelas combinando menor concentração $(0,025 \%)$ com maior volume $(20 \mathrm{~mL})$ de meio de cultura, indicando ter sido este tempo suficiente para a difusão do corante em toda extensão do gel. CODY e colaboradores ${ }^{45}$, também, relataram que no período de 1 hora a solução de TTC a $0,1 \%$ se difundiu completamente através de $20 \mathrm{~mL}$ de ágar.

No meio de cultura contendo tensoativo, além das colónias com reação positiva, houve formação de halo avermelhado, fato que não favorece a detecção das colônias, uma vez que a viragem puntiforme apresenta contraste melhor.

O prosseguimento deste estudo visou a constatação da aplicabilidade deste recurso em amostras de produtos cuja homogeneização em meio de cultura redunda em sistema opalescente, comprometendo a transparecência do gel e com isto dificultando a visualização pelo contraste.

A escolha do hidróxido de alumínio foi em função da sua característica altamente opalescente e, também, por ser medicamento inscrito na Farmacopéia Americana ${ }^{246}$ constando a especificação de qualidade microbiana com limite de 100 para o número total de microrganismos aeróbicos por mililitro.

A concentração testada foi de $6 \%$ por ser aquela contida em alguns produtos farmacêuticos atualmente comercializados no Brasil, e a adição de 1 $\mathrm{mL}$ desta suspensão diretamente na placa foi efetuada simulando as condições de tais 
amostras, quando submetidas à análise rotineira ou fiscal.

No teste anterior, sem adição de hidróxido de alumínio, obteve-se coloração das colônias suficientemente detectável à vista desarmada, mesmo com a concentração de 0,025\%, no tempo de 1 hora. Entretanto, a intensidade de coloração foi maior nas placas com concentração maior de TTC.

Pelos dados da Tabela XXXV, em números de colônias, verifica-se que a coloração desenvolvida com $0,025 \%$ de TTC, após 1 hora de reação, não foi eficiente para detecção das colónias presentes na placa, uma vez que após 2 horas o número foi maior que aquele obtido na contagem anterior. A concentração de 0,05\% por sua vez, também, não foi eficiente para detecção de todas as bactérias testadas, no período de 1 hora de reação, sendo o número de colônias iguais nos 2 tempos, somente para $S$. aureus. Para as outras bactérias foi necessária a concentração de $0,1 \%$ para obtenção do mesmo resultado.

No ensaio anterior, verificou-se que todas as colônias se tornaram coloridas com 0,025\% em 1 hora de reação, mesmo aquelas localizadas próximas ao fundo da placa. A diferença de resultado dos 2 testes, provavelmente, é decorrente da dificuldade de detecção de colónias, que estão mais no interior do gel, cuja coloração não é suricientemente intensa para visualização em meio com pouca transparência.

O mesmo teste foi efetuado para leveduras (Tabelas XXXIII, XXXIV e XXXVI) empregando-se concentrações maiores de TTC que aquelas testadas para bactérias, pois somente a partir de $0,1 \%$ houve revelação das colônias em meio com opacidade, exigindo 1 hora de contacto. A inclusão de concentrações maiores no teste foi pelo fato de que no meio líquido a quantidade de TTC necessária para detecção da coloração de leveduras foi maior que aquela requerida para bactérias, tomando como base o comportamento da C. albicans.

A reação das colônias de $S$. cerevisiae foi equivalente àquela observada para bactérias. As colônias dessa levedura tornaram-se coloridas após 1 
hora da adição do TTC na concentração de $0,1 \%$, tanto no meio padrão como naquele adicionado de polissorbato.

Em relação à $C$. albicans, no meio padrão, as colônias da superfície tornaram-se coloridas em todas as concentrações do TTC testadas, enquanto as da profundidade apenas com concentração acima de 0,5\%. Essas colônias no meio adicionado de polissorbato, somente, tornaram-se coloridas após 2 horas de reação, mesmo nas concentrações mais elevadas.

A diminuição na reação do TTC no meio líquido com tensoativo havia sido solucionado com a neutralização após a incubação. Como o pH do ágar Sabouraud-dextrose é o mesmo do caldo, recorreu-se também a neutralização do meio. A aplicação do TTC dissolvido em tampão pH 7,5, aumentou a intensidade de coloração das colônias, tanto daquelas da superfície como as da profundidade. Entretanto, mesmo com a neutralização, a concentração mínima e o tempo para o desenvolvimento da coloração, daquelas localizadas na profundidade do meio, no caso que contem polissorbato, foram os mesmos requeridos para a situação em que o TTC havia sido dissolvido em água.

Tendo em vista este resultado, no teste com o agente opalescente foi empregado o corante dissolvido em tampão pH 7,5, nas concentrações que promoveram desenvolvimento das colónias de C. albicans. O S. cerevisiae não foi incluído neste teste, baseando-se no fato de que se as colónias de $C$. albicans forem detectadas, as dessa levedura serão mais facilmente visualizadas, uma vez que a coloração obtida foi mais intensa para a mesma, no teste anterior (4.2.16) em condições idênticas para os dois microrganismos.

As contagens de colônias após 30 minutos e 1 hora foram efetuadas, embora se sabendo pelos resultados do teste anterior (4.2.16), que seriam insuficientes para revelação de todas as colônias. O objetivo destas determinações foi o controle do desenvolvimento da reação, avaliado pela diferença do número de colónias, no decorrer do tempo. 
No teste anterior (4.2.16) verificou-se que a concentração de 0,5\% promovia a coloração de todas as colônias de C. albicans em 2 horas após adição do corante. Entretanto, pelos resultados da Tabela XXXVI, observa-se que esta concentração não possibilitou a deteç̧ão de todas as colônias, mesmo naquelas placas com menor volume de meio de cultura. A justificativa para o dado encontrado é a mesma comentada para bactérias, ou seja, a dificuldade de visualização de colônias que estão mais no interior do meio, entre a superfície e o fundo da placa, que necessitam de maior contraste no meio com opacidade. Neste teste, quando a contagem foi efetuada após 2 horas da adição do TTC, a revelação de todas as colônias desta levedura, independentemente do volume e da natureza do meio de cultura, foi conseguida somente com a concentração de $2 \%$ do corante. Consequentemente, apesar desta concentração ser muito maior que aquela utilizada por outros autores para revelação de colônias, seu emprego será justificável em amostras com opacidade, uma vez que $C$. albicans pode ser o contaminante presente na amostra.

A toxicidade do TTC é considerada a causa da restrição para utilização de concentrações elevadas nos métodos de contagem propostos por alguns autores ${ }^{38,93,254}$. No método em estudo, porém, esse fator não influi no resultado, uma vez que as colônias já estão formadas, não havendo atuação durante a multiplicação dos microrganismos.

Apesar de não se conhecer a resposta de todos os contarninantes, possivelmente presentes na amostra, com a utilização de $2 \%$ de TTC acredita-se que assegure resultados confiáveis, pois baseia-se naquele observado a partir de uma levedura, citada na literatura como sendo não redutora de TTC. 


\subsection{Avaliação da eficiência do cloreto de trifeniltetrazólio aplicado aos métodos de tubos múltiplos e de semeadura em profundidade para determinação de carga microbiana em amostras de produtos comerciais.}

Como foi mencionado anteriormente, a maioria das especificações de qualidade microbiana de produtos constantes nas farmacopéias é de no máximo $10^{2}$ microrganismos $/ \mathrm{g}(\mathrm{mL})^{70,246}$ e para os cosméticos a tendência é a adoção desse mesmo limite.

Nos testes anteriores estudaram-se as variáveis que influem na redução do TTC para otimizar a reação, quando aplicado à contagem de microrganismos viáveis, tanto pelo método do número mais provável como pela semeadura em profundidade, visando aplicação em amostras com carga menor que $10^{2} / \mathrm{g}(\mathrm{mL})$.

Para a avaliação da eficiência do método alternativo, amostras de produtos comercializados foram submetidas à análise por este em comparação ao do número mais provável com sub-cultura, que é o método oficial da Farmacopéia Americana XXII ${ }^{246}$ para amostras de medicamentos com opacidade e carga menor que $10^{2}$ microrganismos/g $(\mathrm{mL})$.

Amostras sem contaminação natural foram testadas após inoculação com microrganismos padrões em número estimado de $10^{2}$ bactérias $/ \mathrm{g}$ $(\mathrm{mL})$, simulando as condições de um produto com essa característica.

A escolha dos microrganismos foi segundo o seguinte critério: a $P$. aeruginosa foi justificada anteriormente; $B$. subtilis, pela alta frequência de bacilos Gram-positivos verificados em medicamentos e cosméticos; $\bigcirc \mathrm{M}$. luteus foi em função da sua maior sensibilidade ao efeito tóxico do TTC que outros germes testados.

A inoculaçào dos microrganismos foi efetuada na dispersão 
preparada com adição de diluente, pois a agressividade das amostras reduzia sua carga quando inoculados diretamente no produto. Mesmo a diluição de 1:10 não possibilitou a recuperação dos 2 microrganismos Gram-positivos nas amostras C2 e C3 e o M. luteus na C1, razão pela qual não foram incluídos nos resultados (Tabela XXXVII)

Amostras originalmente contaminadas foram testadas após ajuste da carga microbiana também para cerca $10^{2} \mathrm{UFC} / \mathrm{g}(\mathrm{mL})$, uma vez que não se dispunha de amostras com carga contaminante natural nessa faixa.

Os métodos oficiais para contagem de microrganismos viáveis preconizam a diluição inicial da amostra de 1:10. Esta diluição não representa inconveniência quando se emprega o método estimativo, mesmo quando se testa amostras com carga microbiana menor que $10^{2} / \mathrm{g}(\mathrm{mL})$, uma vez que esse método foi desenvolvido para aplicação em amostras com baixa carga contaminante.

Para o emprego do método de contagem por "pour-plate" com semeadura de $2 \mathrm{~mL}$ da amostra diluida de 1:10, o número de microrganismos deveria ser maior que 150 ou 125 / g (mL). Para se testar amostras com cargas menores, haveria a necessidade de se semear quantidade maior desta. Neste caso a diluição dos nutrientes pode ser fator desfavorável para o crescimento de microrganismos quando se utiliza volumes de 15 a $20 \mathrm{~mL}$ de meio de cultura.

Em amostras líquidas com pouca viscosidade a semeadura de 1 $\mathrm{mL}$ diretamente no meio de cultura é recurso empregado para superar esse problema. Entretanto, para que são viscosos ou não podem ser amostrados por volume como pomadas, cremes, pós, etc. necessitam serem pesados e diluidos antes de serem inoculados. Além disso, a semeadura direta da amostra, também, apresenta como desvantagem a impossibilidade de neutralização de substâncias antimicrobianas durante a sua preparação, necessitando de adição de substâncias neutralizantes no próprio meio de cultura. Esta prática, apesar de utilizada, pode inibir o crescimento de alguns microrganismos, devendo ser evitada quando se dispõe de outra alternativa. 
A diluição das amostras de 1:4 foi empregada neste trabalho como alternativa para se ter maior número de colónias por placa quando foram testadas amostras com carga menor que $10^{2} / \mathrm{g}(\mathrm{mL})$. Com esta técnica pode-se empregar diluentes contendo neutralizantes de antimicrobianos e também obter número de colônias por placa na faixa considerada mais precisa.

O tempo de incubação recomendado pelos métodos oficiais para determinação de carga bacteriana contaminante varia de 48 horas a 5 dias $\mathbf{3 2 , 6 0 , 7 4 , 2 4 6}$. Pelos dados obtidos no teste anterior ( Tabelas XVI, XVII, XX, XXII) verificou-se que o tempo de incubação de 20 horas não foi suficiente para detecção de $M$. luteus e $P$. aeruginosa pelo TTC. Tendo em vista este dado, decidiu-se pela incubação por 48 horas, antes da adição do corante.

A concentraçào de $500 \mu \mathrm{g} / \mathrm{mL}$ de _ TTC foi considerada mais adequada, baseando-se, também, nos dados de testes anteriores ( Tabelas XV a XXIII) que mostraram ser esta de eficiência igual a $1000 \mu \mathrm{g} / \mathrm{mL}$

O tempo global envolvendo o teste pela técnica de tubos múltiplos com sub-cultura foi de 72 horas enquanto que aproximadamente 50 horas foram gastas pelo mesmo método com TTC. O ensaio pela semeadura em profundidade requereu igual tempo. Logo, a redução de 12 horas pode parecer pouco vantajoso. No entanto, pode representar antecipação de 1 dia para a liberação da matéria-prima ou do produto,o que, sob o apecto empresarial é de grande interesse, pois, qualquer redução no tempo de quarentena representa diminuição de custo do produto.

A opção pelo método alternativo será válido somente quando demonstrado ser este equivalente ao método convencional. Pela análise dos dados obtidos a partir de amostras não contaminadas (Tabela XXXVII) pelo método de tubos múltiplos com sub-cultura e com TTC verifica-se que os 2 foram iguais, razão pela qual não foram submetidas à análise estatística.

A comparação dos dados obtidos pelos métodos de tubos 
múltiplos com sub-cultura e o de semeadura em profundidade com inoculação das amostras diluídas de 1:10 e 1:4 (Tabela XXXVIII) não resultaram em diferença significativa para a maioria das amostras testadas. Em 2 casos em que se verificou diferença, o método de semeadura em profundidade forneceu valores maiores.

A comparação da variabilidade dos métodos alternativos propostos com o de número mais provável (Tabela $\mathrm{XL}$ ) demonstrou ser este significantemente maior, principalmente quando comparado com os dados obtidos da análise envolvendo a diluição 1:4. Ainda que essa diferença não tenha sido observada para todas as amostras, o coeficiente de variação foi sempre maior, indicando menor precisão do método oficial, como era o esperado (Tabela $X X X \mid X$ ). Esta diferença pode ser visualizada na figura 1. A comparação dos coeficientes de variação confirmou ser a diferença significativa $(p<0,0001)$ (Tabela XI_l).

Quando o mesmo teste foi aplicado em amostras contaminadas (Tabela XLII) a diferença entre os 3 métodos foi significativa para 3 amostras com valores de $p$ iguais a $0,083,0,0408$ e 0,0798 (Tabela XLIII). A técnica de semeadura em profundidade com diluição de 1:4 não mostrou diferença significativa em relação a de tubos múltiplos, em 7 das 8 amostras testadas.

A comparação da variabilidade foi semelhante àquele com microrganismos padrões (Tabela XLV), e o coeficiente de variação, também, foi sempre maior para o número mais provável (Tabela XLIV e Fig. 2), confirmando ser esta diferença significativa ( $p<0,0001$ ) (Tabela XLVI).

Os dados obtidos pela técnica de semeadura em profundidade nas diluições 1:10 e 1:4 não foram significativamente diferentes, tanto nas amostras com microrganismos padrões como naquelas com contaminantes. Entretanto, os coeficientes de variação foram sempre menores, indicando maior precisão do método com diluição menor. Este resultado, tarrıbém, confirmou o esperado, considerando que o número de colônias em média, por placa, na diluição 1:10 foi de 4 a 33 UFC para amostras com microrganismos padrões e 5 a 30 UFC para as contaminadas, enquanto 
que naqueles com diluição de 1:4 foi, respectivamente, de 18 a 91 e 11 a 73 UFC.

Portanto, pela análise dos resultados obtidos o TTC pode ser empregado para revelação de crescimento microbiano em substituição à sub-cultura, com redução no tempo de análise equivalente ao requerido pela sub-cultura. $O$ método de semeadura em profundidade, com coloração das colônias com TTC, pode ser empregado para se testar amostras com opacidade e carga contaminante menor que $10^{2}$ UFC/g (mL), como alternativa do método oficial. A diluição da amostra de 1:4 resultou em maior precisão, mantendo a vantagem da possibilidade de neutralizar os conservantes através da inclusão de inativadores no próprio diluente. 


\section{PROposta de método anAlítico oficial para O teste de limite MICROBIANO EM MEDICAMENTOS HIDROINSOLÚVEIS FORTEMENTE OPALESCENTES E COM BAIXA CARGA MICROBIANA (NÃO MAIS QUE $10^{2}$ UFC/G (ML)}

\subsection{Método para contagem de microrganismos aeróbios em medicamentos e cosméticos na forma de suspensão ou emulsão pela técnica de tubos múltiplos}

Transferir $10 \mathrm{~g}$ ( $\mathrm{mL}$ ) de amostra para $90 \mathrm{~mL}$ de diluente esterilizado. Se necessário aquecer a dispersão a $45 \pm 1^{\circ} \mathrm{C}$ por tempo não superior a 30 minutos, até obtenção de mistura homogênea. Proceder às diluições decimais seriadas no mesmo diluente. Transferir alíquotas de $1 \mathrm{~mL}$ de cada diluição para série de 3 tubos, contendo $10 \mathrm{~mL}$ de caldo caseina-soja. Incubar em estufa a $30-35^{\circ} \mathrm{C}$ durante 48 horas. Adicionar para cada tubo $0,5 \mathrm{~mL}$ de solução de cloreto de trifeniltetrazólio a $1 \%$, em água destilada, esterilizada por filtração em membrana de 0,45 $\mu \mathrm{m}$. Reincubar os tubos a $30-35^{\circ} \mathrm{C}$ durante 1 hora e efetuar a leitura, considerando como positivo aqueles com viragem do indicador para coloração alaranjada, rósea ou avermelhada.

Em se tratando de detecção de leveduras, substituir o meio por caldo Sabouraud-dextrose e usar o revelador na concentração de $5 \%$, sendo que a todos os tubos devem ser adicionados, previamente, $0,5 \mathrm{~mL}$ de solução aquosa de hidróxido de sódio $2 \mathrm{~N}$. 


\subsection{Método para contagem de microrganismos aeróblos em medicamentos e cosméticos, na forma de suspensáo e ou emulsăo, pela técnica de semeadura em profundidade}

Transferir $10 \mathrm{~g}(\mathrm{~mL})$ de amostra para $30 \mathrm{~mL}$ de diluente esterilizado. Se necessário aquecer a dispersão a $45 \pm 1^{\circ} \mathrm{C}$, por tempo não superior 30 minutos, até obtenção de mistura homogênea. Proceder às diluições decimais seriadas no mesmo diluente. Transferir alíquotas de $2 \mathrm{~mL}$ de cada diluição para réplicas de 3 placas. Adicionar 15 a $20 \mathrm{~mL}$ de ágar caseina-soja esterilizado a $48 \pm 2^{\circ} \mathrm{C}$ homogeneizar a mistura. Incubar as placas em estufa a $30-35^{\circ} \mathrm{C}$ durante 48 horas. Cobrir a superfície do meio de cultura com $5 \mathrm{~mL}$ de ágar a $1 \%$ em água destilada, contendo $0,1 \%$ de cloreto de trifeniltetrazólio, fundido e resfriado a $48 \pm 2^{\circ} \mathrm{C}$. Reincubar as placas a $30-35^{\circ} \mathrm{C}$ durante 1 hora e proceder à contagem de colônias alaranjadas, róseas ou vermelhas.

Em se tratando de deteç̧ão de leveduras, substituir o meio para ágar Sabouraud-dextrose e usar o corante na concentração de $2 \%$, sendo o ágar preparado em solução tampão fosfato pH 7,5. 


\section{CONCLUSÕES}

8.1 No teste de limite microbiano pela técnica de NMP a presença de TTC em concentração biocompatível desde o início da incubação pode conduzir a resultado falso negativo.

8.2 Pela adição de TTC ao meio de cultura, a resposta positiva está na dependência do tipo de contaminante, do inóculo, da concentração do corante e do tempo de reação.

8.3 A sensibilidade para detecção da suspensão microbiana através da coloração do trifenilformazano é equivalente aquela que se baseia na turvação, desde que conferido tempo necessário para a reação.

8.4 A glicose e o ácido glutâmico adicionados ao caldo caseína-soja não aumentam a sensibilidade da reação do TTC, em culturas bacterianas.

8.5 O polissorbato 20 promove a difusão extra-celular do trifenilformazano, e não aumenta a sensibilidade do teste, tanto em meio líquido como sólido.

8.6 O tempo de incubação no teste de limite microbiano pela técnica de NMP deve ser superior a 20 horas, quando utilizado o TTC como revelador.

8.7 No teste de limite microbiano visando leveduras, o tempo de incubação deve ser superior a 72 horas quando empregada a técnica de NMP com TTC.

8.8 $\mathrm{Na}$ análise de amostras quanto a microrganismos contaminantes em meio líquido deve-se evitar a adição de polissorbato 20 ao meio de cultura. 
8.9 A concentração recomendável de TTC a ser adicionada no meio de cultura líquido é de $500 \mu \mathrm{g} / \mathrm{mL}$ para detecção de bactérias e de $2.500 \mu \mathrm{g} / \mathrm{mL}$ para leveduras em meio neutralizado.

8.10 $\mathrm{Na}$ análise de amostras intensamente turvas, pela técnica de semeadura em profundidade a concentração mínima eficaz de TTC é 0,1\% para análise de bactérias e de 2,0\% em meio neutralizado para leveduras.

8.11 A revelaçào do crescimento microbiano pelo TTC no método de tubos múltiplos é equivalente ao da sub-cultura, quando analisadas amostras com opacidade.

8.12 A aplicação do TTC possibilita a análise de medicamentos e de cosméticos com opacidade pelo método de semeadura em profundidade.

8.13 O tempo para a obtenção de resultados pelo método oficial é de 72 horas e de 50 para o alternativo.

8.14 $\mathrm{Na}$ análise de produtos com opacidade,a precisão do método de semeadura em profundidade com revelação de colônias com TTC é maior que a do número mais provável.

8.15 $\mathrm{Na}$ análise de produtos com opacidade e carga microbiana menor que $10^{2} \mathrm{UFC} / \mathrm{g}$ $(\mathrm{mL})$ a semeadura da amostra diluida de 1:4 aumenta a precisão, quando comparada àquela de 1:10, pelo método de semeadura em profundidade. 


\section{REFERÊNCIAS BIBLIOGRÁFICAS}

1 ABELE, C. A. The methylene-blue reduction test as a means of estimating the bacterial content of milk to determine its suitability for pasteurization or as basis for grading. J. Milk Technol., Ames, v. 8, p. 67-79, 1945.

2 AMERICAN PUBLC HEALTH ASSOCIATION. Standards methods for the examination of water and wastewater. 16. ed. Washington: American Water Work Association and Water Pollution Control Federation, 1985.

AMERICAN PUBLIC HEALTH ASSOCIATION. Technical Commitee on Microbiological Methods for Foods. Compendium of methods for the microbiological examination of foods. 2.ed., Washington, 1984.

4 ANDERSON, B. Pharmaceutical applications for the Bactec 460. J. Appl. Bacteriol., Oxford, v .61, p.v-vi, 1986.

5 ANDREWS, W. H., MESSER, J. Microbiological methods. In: ASSOCIATION OF OFFICIAL ANALYTICAL CHEMISTS. Methods of analysis of the Association of Offical Analytical Chemists. 15. ed., Arlington, 1990. p. 425-496.

6 ANDREWS, W. H., WILSON, C. R., POELMA, P. L Glucuronidase assay in a rapid MPN determinations for recovery of Escherichia coli from selected foods. J. Assoc. Off. Anal. Chem., Washington, v. 70, n. 1, 1987.

7 ANON. The bacteriological examination of drinking water supplies. HMSO. London. Apud: BAIRD, R. M. Monitoring microbiological quality: conventional testing methods. In: BLOOMFIELD, S. F., BAIRD, R., LEAK, R. E., LEECH, R. Microbial quality assurance in pharmaceuticals cosmetics and toiletries. London: Ellis Horwood, 1988, p.126-144. 
8 ANON. CTPA recommended microbiological limits and guidelines for microbiological quality control. Cosmetic, Toiletry and Perfumery Association, London. Apud: BAIRD, R. M. Monitoring microbiological quality: conventional testing methods. In: BLOOMFIELD, S. F., BAIRD, R. LEAK, R. E., LEECH, R. Microbial quality assurance in pharmceuticals cosmetics and toiletries. London: Ellis Horwood, 1988 , p. $126-144$.

9 AURELI, P. , PASOIINI, B. Requisiti microbiologici dei farmaci non obbligatoriamente sterili. Boll. Chim. Farm., Milano, v. 124, p. 229-243, 1985.

10 BAIRD, R. M. Microbial contamination of cosmetic products. J.Soc. Cosmet. Chem., Easton, v. 28, p. 17-20, 1977.

11 BAIRD, R. M. Microbiological contamination of manufactured products: official and unofficial limits. In: BLOOMFIELD, S. F., BAIRD, R. M., LEAK, R.E., LEECH, R. Microbiological quality assurance in pharmaceutical, cosmetics and toiletries. Chichester: Ellis Horwood, 1988. p. 61-75.

12 BAIRD, R. M. Monitoring microbiological quality: conventional testing methods. In: DENYER, S. P., BAIRD, R. M. Guide to microbiological control in pharmaceuticals. London: Ellis Horwood, 1990. p. 125-145.

13 BAIRD, R. M., PETRIE, P. S. A study of microbiological contamination of oral medicaments. Pharm. J., London, v. 226, p. 10-11, 1981.

14 BALEBONA, M. C., MORIÑIGO, M. A., CORNAX, R. , BORREGO, J. J., TORREGROSSA, V. M., GAUTHIER, M. J. Modified most-probable-number technique for the specific determination of Escherichia coli from environmental samples using a fluorogenic method. J. Microbiol. Methods, Amsterdam, v. 12, n. $3-4$, p. $235-245,1990$. 
15 BARTLETT, R. C., MAZENS, M. F. Rapid antimicrobial susceptibility test using tetrazolium reduction. Antimicrob. Agents Chemother., Ann Arbor, v. 15, n. 6, p. 769-774, 1979.

16 BARTLETT, R. C., MAZENS, M., GREENFIELD, B. Acceleration of tetrazolium reduction by bacteria. J. Clin. Microbiol., Washington, v. 3, n. 3, p. 327-329, 1976.

17 BARZAGHI, D., BONOMI, E., CAFIERO, M., CARAZZONE, M., GeNOVA, R., GIGLIOLI, N., NERI, G., VERONESE, M. Comparison of three bacterial count methods between laboratories. Boll. Chim. Farm., Milano, v. 119, n. 5, p. $309-$ $313,1980$.

18 BARZAGHI, D., BELA , G., BIZZARRI, D., BURINATO, C., CAFIERO, M., CARAZZONE, M., FAVA, M., GENOVA, R., PIOVANI, D., VERONESE, M. ॥ conteggio microbico mediante filtrazione per membrana - considerazioni sulla riproducibilitá dei risultati. Boll. Chim. Farm., Milano, v. 121, p. 43-52, 1982.

19 BELL, R. H., POWER, D. A., RICHARDSON, G. H. Media. In: AMERICAN PUBLIC HEALTH ASSOCIATION. Technical Commitee on Microbiological Methods for Foods. Compendium of methods for the microbiological examination of foods. 2. ed. Washington, 1984.

20 BERRY, J. M., Mc NEILL, D. A., WITTER, L. D. Effect of delays in pour plating on bacterial counts. J. Dairy Sci., Champaign, v.52, p. 1456-1457. 1969.

21 BEVERIDGE, E. G., HOPE, I. A. Microbial content of pharmaceutical solutions. Pharm. J., London, v. 207, p. 102-103, 1971. 
22 BIELIG, H. J., KAUSCHE, G. A., HAARDICK, H. Uber den nachweis von reduktionsorten in bakterien . Z. Naturforsch, 4b, 80-91, 1949. Apud: KOPPER, P. H. Studies on bacterial reducing activity in relation to age of culture. J. Bacteriol., Baltimore, v. 63, n. 5, p. 639-645, 1952.

23 BLAUG, S. M. , AHSAN, S. S. Interaction of sorbic acid with nonionic macromolecules. J. Pharm. Sci., Washington, v. 50, n. 2, p. 138-141, 1961.

24 BONOMI, E., NEGREITI, F. Ricerche sul contenuto microbico di materie prime impiegatte nelle preparazioni farmaceutiche. Ann. Ist. Super. Sanità, Roma, v. 13, n.4, p. 805-832, 1977.

25 BOPP, C. A., WACHSMUTH, I. K. Luciferase assay to detect bacterial contamination of intravenous fluids. Am. J. Hosp. Pharm., Washington, v. 38, p. 1747-1750, 1981.

26 BOWDEN, W. B. Comparison of two direct-count techniques for enumerating aquatic bacteria. Appl. Environ. Microbiol., Washington, v. 33, n. 5, p. 12291132, 1977.

27 BOWMAN, F. W., WHTE, M., LYLES, R. L Microbial contamination of nonsterile antibiotic. Market samples: a survey. J. Pharm.Sci., Wahington, v. 60, n. 7, p. 1099-1101, 1971.

28 BREED, R. S., DOTTERRER, W. D. The number of colonies allowable on satisfactory agar plates. Tech. Bull.. 53. New York Agri. Exper. Sta. Geneva, N. Y. 1916. Apud: BUSTA, F. F., PETERSON, E. H., ADAMS, D. M., JOHNSON, M. G. Colony count methods. In: AMERICAN PUBLIC HEALTH ASSOCIATION. 
Technical Commitee on Microbilogical Methods for Foods. Compendium of methods for the microbiological examinations of foods. 2. ed., Washington, 1984. p. 62-83.

29 BREWER, H. E. Tetrazolium chloride as a test for damage in artificially cured peanuts. Science, Washinton, v. 110, n. 2861, p. 451-452, 1949.

30 BRITISH pharmacopoeia. London: Her Majesty's Stationery Office, 1973.

31 BRITISH pharmacopoeia. London: Her Majesty's Stationery Office, 1980.

32 BRITISH pharmacopoeia. London: Her Majesty's Stationery Office, 1988. v. 1.

33 BRODIE, A. F. , GOTS, J. S. Effects of an isolated dehydrogenase enzyme and flavoprotein on the reduction of triphenyltetrazolium chloride. Science, Washington, v. 114, n. 2950, p. 40-41, 1951.

$34 \mathrm{BRUCH}, \mathrm{C}$. W. Posible modifications of USP microbial limits and tests. Drug Cosmet.Ind., New York, v. 110, n. 6, p. 32-37, 116-121, 1972.

35 BRUNIUS, G. Technical aspects of the use of 3,6,-diacetyl fluorescein for vital fluorescent staining of bacteria. Current Microbiol., New York, v. 4, p. 321-323, 1980.

36 BUHLMANN, $X$. Method for microbiological testing of nonsterile pharmaceuticals. Appl. Microbiol., Baltimore, v. 16, n. 12, p. 1919-1923, 1968.

37 BUOGO, A. , RATTI, L. Methods for the microbiological control of nonsterile drugs. Farmaco Ed. Prat., Pavia, v. 27, n. 9, p. 523-531, 1972. 
38 BUSTA, F. F., PETERSON, E. H. , ADAMS, D. M., JOHNSON, M.G. Colony count methods. In: AMERICAN PUBLC HEALTH ASSOCIATION. Technical Commitee on Microbiological Methods for Foods. Compendium of methods for the microbiological examinations of foods. 2. ed., Washington, 1984. p. 62-83.

39 BUTTERFIELD, D. C. T. The selection of a dilution water for bacteriological examinations. J. Bacteriol., Baltimore, v. 23, p. 355-368, 1932.

40 CADY, P., DUFOUR, S. W., SHAW, J. KRAEGAR, S. J. Electrical impedance measurements: rapid methods for detecting and monitoring micro-organisms. J. Clin. Microbiol., Washington, v. 7, p. 265-272, 1978.

41 CALICH, V. L. G., PURCHIO, A., PAULA, C.R. A new fluorescent viability test for fungi cells. Mycopathologia, The Hague, v. 66, n. 3, p. 175-177, 1978.

42 CARVALHAL, M. L C., OLIVEIRA, M. S., ALTERTHUM, F. An economical and time saving alternative to the most-probable number method for the enumeration of microorganisms. J. Microbiol. Methods, Amsterdam, v. 14, n. 3, p. 165-170, 1991.

43 CÉSKOSLOVENSKY LECÓPIS, 2 vyd. (1954) Czechoslovakian Pharmacopoeia. 2. ed. Prague, p. XVII. Apud: WORLD HEALTH ORGANIZATION. Microbiological contamination of nonsterile drugs. WHO/PHARM/69453. 10p. [mimeogr.]

44 CLARK, D. S. Comparison of pour and surface plates methods for determination of bacterial counts. Can. J. Microbiol., Toronto, v. 13, p. 1409-1412, 1967. 
45 CODY, H. J., SMITH, P. F., BLASER, M. J., La FORCE, F. M., WEN-LAN, L. Comparison of methods for recovery of Escherichia coli and Staphylococcus aureus from seeded laundry fabrics. Appl. Environ. Microbiol., Washington ,v.47, n. 5, p. 965-970, 1984.

46 COLLNS, C. H. Food microbiology. Microbiological methods. London: Butterworths, 1976. p. 262-311.

47 COMMITTE OF OFFICIAL LABORATORIES AND DRUG CONTROL SERVICES. Section of industrial pharmacists - FIP. Microbiological purity of non-compulsory sterile pharmaceutical preparations: methods of examination. Pharm. Acta Helv., Zurich, v. 51, n. 3, p. 33-40, 1976.

48 COOPER, K. E. The theory of antibiotic inhibition zones. In: KAVANAGH, F. Analytical microbiology. New York: Academic Press, 1963.v. 1, p. 1-83.

49 CORRÊA, B. Avaliação da eficácia do método de fluorescência (solução de diacetato de fluoresceína e brometo de etídio) no estudo da viabilidade de amostras de leveduras não capsuladas (Candida albicans) e capsuladas (Cryptococcus neoformans). São Paulo. 1984. [ Dissertação - Mestrado, Instituto de Ciências Biomédicas - USP ]

50 CRANSTON, P. M., CALVER, J. H. Quantitative fluorescent microscopy of yeasts in beverages. Food Technol. Austr. Sydney, v. 26, n. 1, p. 15-17, 1974.

51 CURRIER, H. B., DAY, B. E. The tetrazolium reaction in yeast. Science, Washington, v. 119, p. 817, 1954. 
52 CUTLER, R. R., WILSON, P., CLARKE, F. V. Evaluation of a radiometric method for studying bacterial activity in the presence of antimicrobial agents. J. Appl. Bacteriol., Oxford, v. 66, p. 515-521, 1989.

53 DAHLÉN, G., LINDE, A. Screening plate method for detection of bacterial glucuronidase. Appl. Microbiol., Baltimore, v. 26, n. 6, p. 863-866, 1973.

54 DARKEN, M. A. Microbiological process report. Natural and induced fluorescence in microscopic organisms. Appl. Microbiol., Baltimore, v. 9, p. 354-360, 1961.

55 DAUTA, J. A staining method for the detection of impaired photosynthetic electron transport in green algae strains. Biosci. Rep., 3(4): 367-71, 1983. Apud: Chem. Abstr., Columbus, v. 99, n. 49831e, 1983.

56 DAVISON, A. L. Microbial standards for pharmaceuticals. In: DENYER, S. P., BAIRD, R. M. Guide to microbiological control in pharmaceuticals. London: Ellis Horwood, 1990. p. 356-365.

57 DENYER, S. P. Monitoring microbiological quality: application of rapid microbiological methods to pharmaceuticals. In: DENYER, S. P., BAIRD, R. M. Guide to microbiological control in pharmaceuticals. London: Ellis Horwood, 1990. p 146-156.

58 DENYER, S. P., WARD, K. H. A rapid method for the detection of bacterial contaminats in intravenous fluids using membrane filtration and epifluorescence microscopy. J. Parenter. Sci. Technol. Philadelphia, v. 37, n. 5, 1983.

59 DENYER, S. P., LYNN, R. A sensitive method for the rapid detection of bacterial contaminants in intravenous fluids. J. Parenter. Sci. Technol., Philadelphia, v. 41, ก. 2, 1987. 
60 DEUTCHES Arzneibuch. 9. ed . Stuttgart: Deutscher Apotheker Verlag, GoviVerlag Gmbh. 1986.

61 DICKENS, F., MC ILWAIN, H. Phenazine compounds as carriers in the hexosemonophosphate system. Biochem. J., London, v. 32, p. 1615-1625, 1928.

62 DOCUMENTO S. I. S. F. Proposta " Grupo biologico" "Metodi per il controllo microbiologico de farmaci non sterili". PA/PH EXP. I cm/t (75) l.12/2/75. Apud: TAGLIAPIETRA, L. La qualita microbiologica nei prodotti farmaceutici non obbligatoriamente sterili. Boll. Chim. Farm., Milano, v. 117, n. 1, p. 1-13, 1978.

63 DONKERSLOOT, J. A., ROBRISH, S. A., KRICHEVSKY, M. I. Fluorometric determination of deoxyribonucleic acid in bacteria with ethidium bromide. Appl. Microbiol., Baltimore, v. 24, n. 2, p. 179-183, 1972.

64 DONNELY, C. B., GILCHRIST, J. E., PEELER, J. E., CAMPELL, J. E. Spiral plate count method for the examination of raw and pasterurized milk. Appl. Environ. Microbiol., Washington, v. 32, p. 21-27, 1976.

65 EDMONDSON, J. E., GOLDEN, R., WEDLE, D. B. Reduction methods. In: RICHARDSON, G. H. Standard methods for examination dairy products. 15. ed., Washington: American Public Health Association. 1984. p. 259-264.

66 EIKOFF, T. C. Nosocomial salmonellosis due to carmine. Ann. Intern. Med., Philladelphia, v. 66, n. 4, p. 813-814, 1967.

67 EUROPEAN pharmacopoeia. 2. ed. Paris: Maisonneuve, 1980. 
68 EUROPEAN pharmacopoeia. 2. ed. Paris: Maisonneuve, 1983.

69 EUROPEAN pharmacopoeia. 2. ed. Paris: Maisonneuve, 1985.

70 EUROPEAN pharmacopoeia. 2. ed. Paris: Maisonneuve, 1991.

71 EVANS, J. R., GILDEN, M. M., BRUCH, C. W. Methods for isolating and identifying objectionable Gram-negative bacteria and endotoxins from topical products. J. Soc. Cosmet. Chem., New York, v. 23, n. 8, p. 549-564, 1972.

72 FARMACOPEA internacionale. 3.ed., Geneve:Organization Mundial de la Salud, 1989. v. 3.

73 FARMACOPÉIA brasileira . 3. ed. São Paulo: Organiação Andrei, 1977.

74 FARMACOPÉIA brasileira. 4. ed. São Paulo: Atheneu, 1988.

75 FARMACOPÉIA dos Estados Unidos do Brasil. 2. ed. São Paulo: Siqueira, 1959.

76 FARMACOPEIA UFFICIALE DELLA REPUBLCA ITALIANA. 7. ed. Roma: Instituto Poligráfico dello Stato P. V., 1965.

77 FERREIRA, J. M., FREITAS, Y. M. Microbiological survey of talcum powders and raw materials. Cosmet. Toiletries, Oak Park, v. 91., n. 9, p. 19-26, 1976.

78 FIRSTENBERG-EDEN, R. A. Collaborative study of the impendence method for examining raw milk samples. J. Food Prot., Ames, v. 47, p. 707-712, 1984. 
79 FIRSTENBERG-EDEN, R. A., TRICARICO, M. K. Impedimetric determination of total mesophilic and psychrotrophic counts in raw milk. J. Food Sci., Chicago, v. 48, p. $1750-1754,1983$.

80 FISCHER, A., FUGLSANG-SMIDT, B., ULRICH, K. Microbial content in non-sterile pharmaceuticals. IV. Tablets. Dan. Tidsskr. Farm., Copenhagen, v. 42, p. $125-$ $131,1968$.

81 FOOD AND DRUG ADMINISTRATION (FDA). Microbiological analytical manual for cosmetics. 1976. 24p.

82 FOWLER, J. L, CLARK, W. S., FOSTER, J. F., HOPKINS, A. Analyst variation in doing the standard plate counts as described in Standard Methods for the Examination of Dairy Products. J. Food Prot, Ames, v. 41, n. 1, p. 4-7, 1978.

83 FRED , R. B., KNIGHT, S. G. The reduction of 2,3,5-triphenyltetrazolium chloride by Penicillium chrysogenum. Science, Washington, v. 109, p. 169-170, 1949.

84 FUGLSANG-SMIDT, B., ULRICH, K. Microbial content in non-sterile pharmaceuticals. V. Tablets. Dan. Tidsskr. Farm., Copenhagen, v. 42, p. 257 263, 1968.

85 GABIS, D. A., MESSER, J. W., MIDURA, T. F., PEELER, J. T. Sampling plans, sample collection, shipment, and preparation for analysis. In: AMERICAN PUBLC HEALTH ASSOCIATION. Technical Commitee on Microbiological Methods for Foods. Compendium of methods for the microbiological examination of foods. 2. ed. Washington, 1984. 
GARCIA-DORADO, D. THEROUX, P., MUNOZ, R., ALONSO, J. ELIZAGA, J., FERNANDE-AVILES, F., BOTAS, J., SOLARES, J., SORIANO, J., DURAN, J. M. Favorable effects of hyperosmotic reperfusion on myocardial edema and infart size. Am. J. Physiol., Bethesda, v. 262, p. PH 17-22, 1992.

87 GERSHENFELD, L., WEBER, Jr. L. S. Bacterial variants produced in culture media containing 2,3,5-triphenyltetrazolium chloride. Am. J. Pharm., Philadelphia, v. 123, n. 6, p. 203-207, 1951.

88 GERSHMAN, M. Color-coding chromevalent antigen. J. Bacteriol., Baltimore, v .86, p. 883-884, 1963.

89 GIFFORD, R. R. M., BORING, J. R. Use of tetrazolium for faster MIC determinations. Clin. Res., Thorofare, v. 20, n. 3, p. 528, 1972.

90 GILCHRIST, J. E., CAMPBELL, J. E. , DONNELIY, C. B. PEELER, J. T., DELANEY, j. M. Spiral plate method for bacterial determination. Appl. Microbiol., Baltimore, v. 25 , p. $244-252,1973$.

91 GILCHRIST, J. E., DONNELLY, C. B., PEELER, J. T. DELANEY, J. M., CAMPBELL, J. E. Collaborative study comparing the spiral plate and aerobic plate count methods. J. Assoc. Offic. Anal. Chem., Washington, v. 60, p. 807-812, 1977.

92 GNANS, S., LUEDECKE, L. O. Impedance measurements in raw milk as an alternative to the standard plate count. J. Food Prot., Ames, v. 45,n. 1, p. 4-7, 1982.

93 GOSHKO, M. A. The use of TTC in USP plate count medium for enumerating low levels of bacteria from insoluble materials. Pharm. Technol., Marina del Rey, v. 8, p. 58, 60, 1984. 
94 GREENE, Jr., L. W., HESSELTINE, H. C. Use of ultraviolet light and fluorescent dyes in bacterial counting. Proc. Soc. Exp. Biol. Med., New York, v. 74, p. 171$173,1950$.

95 GUNZ, F. W. Reduction of tetrazolium salts by some biological agents. Nature, London, v. 163, n. 4133, p. 98, 1949.

96 HALVORSON, H. O., ZIEGLER, N. R. Application of statistics to problem in bacteriology. II. A consideration of the accuracy of dilution data obtained by using a single dilution. J. Bacteriol., Baltimore, v. 26, n. 4, p. 331-339.

97 HALVORSON, H. O., ZIEGLER, N. R. Application of statistics to problem in bacteriology. III. A consideration of the accuracy of dilution data obtained by using several dilutions. J. Bacteriol., Baltimore, v. 26, p. 559-567.

98 HARDY, P. C., EDERER, G. M., MATSEN, J. M. Contamination of commercially packaged urinary catheter kits with the Pseudomonas EO-1. N. Engl. J. Med., Boston, v. 282., n.1, p. 33-35, 1970.

99 HILLIS, S. The isolation of Cl. tetani from ifected talc. New Zealand Med. J., v.45, p. 419-423, 1946. Apud: BRUCH, C. W. Objectionable micro-organisms in nonsterile drugs and cosmetics. Drug Cosmet. Ind., New York, v. 111, n. 4, p. 51$54,150-156,1972$.

100 HIRSCH, J. I., CANADA, Jr., A. T., RANDALL, E. L. Microbial contamination of oral liquid medications. Am. J. Hosp. Pharm., Washington, v. 26, p. 625-629, 1969. 
101 HOBBIE, J. E., DALEY, R. J., JASPER, S. Use of nucleopore filters for counting bacteria by fluorescence microscopy. Appl. Environ. Microbiol., Washington, v. 33, n. 5, p. 1225-1228, 1977.

102 HOUGHTBY, G. A., MATURIN, L. J., KELLEY, W. R. Alternative microbiological methods. In: RICHARDSON, G. H., Standard methods for the examination of dairy products. 15. ed., Washington: American Public Health Association, 1984. p. 151-171.

103 HUDDLESON, F. , BALTZER, B. Differentiation of bacterial species and variation within species by means of 2,3,5-triphenyltetrazolium chloride in culture medium. Science, Washington, v. 112, n. 2918, p. 651-652, 1950.

104 HUHTANEN, C. N., BRAZIS, A. R., ARLEDGE, W. L, COOK, E. W., DONNELLY, C. B., GINN, R. E., JEZESKI, J. J., PUSH, D., RANDOLPH, H. E., SING, E. L. Effects of time of holding on counts of bacteria from raw milk. J. Milk Food Technol., Ames, v.35, p. 126-130, 1972.

105 HUHTANEN, C. N., BRAZIS, A. R., ARLEDGE, W. L, DONNELLY, C. B., GINN, R. E.,RANDOLPH, H. E. A comparison of phosphate buffered and distilled water dilution blanks for the standard plate count. J. Milk Food Technol., Ames,v. 38, n. 5, p. 264-268, 1975.

106 HURWITZ, S. J., MC CARTHY, T. J. 2,3,5-tripheniltetrazolium chloride as a novel tool in germicide dynamics. J. Pharm. Sci., Washington, v. 75, n.9, p. 912-916, 1986.

107 ISAYAMA, K., PITTS, L. H., NISHIMURA, M. C. Evaluation of 2,3,5triphenyltetrazolium chloride staining to delineate rat brain infarcts. Stroke, Dallas, v. 22, n. II, p. 1394-1398, 1991. 
108 JAMBOR, B. Mechanism of the reduction of tetrazolium salts. Nature, London, v. 176, n. 4482, p. 603, 1955.

109 JARVIS, B., EASTER, M. C. Rapid methods in the assessment of microbiological quality ; experiences and needs. J. Appl. Bacteriol., Baltimore, v. 63, n. 16 suppl., p. 115s-126s, 1987.

110 JAYASEKARA, B., CLAYDEN, E. J. Determination of low level microbiological contamination in cosmetics by thin film agar. Cosmet. Toiletries, Oak Park, v. 93, p. 67-73, 1978.

111 JENSEN, J. B. Triphenyltetrazolium chloride test. Lancet, London, v. 2, n. 7424, p. $1247,1965$.

112 JERCHEL, D., MOHLE, W. Ber., 77 B, 591, 1944. Apud: SMITH, F. E. Tetrazolium salt. Science, London, v. 113, n. 2948, p. 751-754, 1951.

113 JOHNS, C. K. Relation between reduction times and plate counts of milk before and after pasteurization. J. Milk Food Technol., Ames, v. 17, p. 369-371, 1954.

114 JOHNSON, T. L, FORBES, B. A., O'CONNOR-SCARLET, M., MACHINSKI, A., MC CLATCHEY, K. D. Rapid method of MIC determinations utilizing tetrazolium reduction. Am. J. Clin. Pathol., Philadelphia, v. 83, n. 3, p. 374-378, 1985.

115 JOHNSTON, W. E., VINTEN-JOHANSEN, J., SHUGART, H. E., SANTAMORE, W. P. Positive end-expiratory pressure potentiates the severity of canine right ventricular ischemia-reperfusion injury. Am. J. Physiol., Bethesda, v. 262, p. H168-H176, 1992. 
116 JONES, P. H., PRASAD, D. The use of tetrazolium salts as a measure of sludge activity. J. Water Poll. Control Fed., Washington, v. 41, n. 11, p. R441-R449, 1969.

117 KAISERMAN, J. M., MORAL, J., WOLF, B. A. A rapid impedimetric procedure to determine bacterial content in cosmetic formulations. J. Soc. Cosmet. Chem., Washington, v. 40, p. 21-31, 1989.

118 KALINGS, L O., RINGERTZ, O., SILVERSTOLPE, .L, ERNERFELDT, F. Microbiological contamination of medical preparations. Acta Pharm. Suec., Stockholm, v. 3, n. 3, p. 219-228, 1966.

119 KENNER, B. A., CLARK, H. F., KABLER, P. W. Fecal streptococci. I. Cultivation and enumeration of streptococci in surface waters. Appl. Microbiol., Washington, 9, p. 15-20, 1961.

120 KOBURGER, J. H. Pouring of petri plates: a potential source of error. J. Food Prot., Ames, v. 43, p. 561-562, 1980.

$121 \mathrm{KOCH}, \mathrm{A}$. L Growth measurement. Manual of methods for general bacteriology. Washington: American Society of Microbiology, 1981. p. 179-207.

$122 \mathrm{KOCH}, \mathrm{A}$. L Estimation of the most probable numer with a programable pocket calculator. Apll. Environ. Microbiol., Washington, v. 43, n. 2, p. 488-490.

123 KOHN, S. R., GERSHENFELD, L, BARR, M. Effectiveness of antibacterial agents presently employed in ophthalmic preparations as presevative against Pseudomonas aeruginosa. J. Pharm. Sci., Washington, v. 52, p. 967-974, 1963. 
124 KOHUT, J. J., BEDNAR, M. M., KIMELBERG, H. K., Mc AUUFFE, T. L., GROSS, C. E. Reduction in ischemic brain injury in rabbits by the anion transport inhibitor L-644, 711. Stroke, Dallas, v. 23, n. 1, p. 93-97, 1992.

125 KOLLING, I. G., SCHAPOVAL, E. E. Controle de qualidade microbiologica de produtos cosméticos. Aerosol Cosmet, São Paulo, v. 34, p. 4-10, 1984.

126 KOMARMY, L E., OXLEY, M. E., BRECHER, G. Hospital-acquired salmonelosis traced to carmine dye capsules. N. Engl. J. Med., Boston, v. 276, n. 15, p. 850852, 1967.

127 KOPPER, P. H. Studies on bacterial reducing activity in relation to age of culture. J. Bacteriol., Baltimore, v. 63, n. 5, p. 639-645, 1952.

128 KORN, M. Y., KUSHNAREV, V. M. The effect of various tetrazolium salts on bacterial reproduction. Mikrobiologyia, v. 34, n. 3, p. 469-472, 1965. Apud: Chem. Abstr., Columbus, v. 63, n. 8767f, 1965.

129 KOUJIMA,I., KANEMASA, Y. Improvement of the membrane filter technique for enumeration of enterococci in water. Nippon Saikingaku Zashi, Tokyo, v. 44, n. 6, p. 813-816, 1989.

130 KUHN, R., JERCHEL, D. Ber. Deutsch. Chem. Ges., 74-B, 949, 1941. Apud: GUNZ, F. W. Reduction of tetrazolium salts by some biological agents. Nature, London, v. 163, n. 4133, p. 98, 1949.

$131 \mathrm{KUN}, \mathrm{E}$. Mechanism of enzymatic reduction of triphenyltetrazolium chloride. Proc. Soc. Exp. Biol. Med., New York, v. 78, p. 195-197, 1951. 
132 KUN, E., ABOOD, L G. Colorimetric estimation of succinic dehydrogenase by triphenyltetrazolium chloride. Science, London,v. 109, n. 2824, p. 144-146, 1949.

133 KUSEWICZ, D., PIATKINWRZ, A. Use of tetrazolium blue in determination of the activity of yeast. Postepy mikrobiol., v. 9 n. 3, p. 563-567, 1970. Apud: Chem. Abstr., Columbus, v. 75, n. 59602z, 1971.

134 LAMBIN, S., DESVIGNES, A., KIGER, J. L, AZRIA, M. Etude de la contamination microbienne des sirops pharmaceutiques. Ann. Pharm. Fr., Paris, v. 30, n. 3, p. 161-168, 1972.

135 LANG, D. J., KUNZ, L J., MARTIN, A. R., SCHROEDER, S. A., THOMSON, L A. Carmine as a source of nosocomial salmonellosis. N. Engl. J. Med., Boston, v. 276, n. 15, p. 829-832, 1967.

136 LARSON, K., WEIBUH, C., CRONBERG, G. Comparison of light and eletron microscopic determinations of the number of bacteria and algae in lake water. Appl. Environ. Microbiol., Washington, v. 35, n. 2, p. 397-404, 1978.

137 LEDERBERG, J. Detection of fermentative variants with tetrazolium. J. Bacteriol., Baltimore, v. 56, p. 695, 1948.

138 LEECH, R. New methodology for microbiological quality assurance. In: BLOOMFIELD, S. F., BAIRD, R., LEAK, R. E., LEECH, R. Microbial quality assurance in pharmaceuticals, cosmetics and toiletries, Chichester: Ellis Horwood, 1988. p. 195-215. 
139 LSKA, B. J., CALBERT, H. E. A test for the detection of lactic bacteriophage using 2,3,5-tripheniltetrazolium chloride. J. Dairy Sci. Champaing, v. 41, p. 776-782, 1958.

140 USKA, B. J., CALBERT, H. E., KNIGT, S. G. Observations on the reduction of 2,3,5triphenyltetrazolium chloride by homofermentative lactic acid bacteria. J. Dainy Sci., Champaing, v. 41, p. 1218-1223, 1958.

141 LUCAS, J. P. Microbiological examination of cosmetics. In: SENZEL, A. J. Newburger's manual of cosmetic analysis. 2. ed., Washington: Association of Official Analytical Chemists, 1977. p. 132-140.

142 LUHDORF, H., TYBRING, L Microbial content in non-sterile pharmaceuticals. VI. Oral liquid preparations. Dan. Tidsskr. Farm., Copenhagen, v. 43, p. 229-237, 1969.

143 MAC LEOD, R. A. , KUO, S. C., GEJUNAS, R. Metabolic injury to bacteria. J. Bacteriol., Baltimore, v. 93, n. 3, p. 961-969, 1967.

144 MADDEN, J. M., JACKSON, G. J. Cosmetic preservation and microbes: viewpoint of the Food and Drug Administration. Cosmet. Toiletries, Oak Park, v. 96, n. 10, p. $75-77,1981$.

145 MANAFI, M., KNEIFEL, W., BASCOMB, S. Fluorogenic and chromogenic substrates used in bacterial diagnostics. Microbiol. Rev., Washington, v. 55, n.3, p. 335-348, 1991.

146 MANUAL ANÁLISES MICROBIOLÓGICAS DE COSMÉTICOS DO INCQS/ FIOCRUZ Grupo de Trabalho de Cosméticos reunidos no INCQS / FIOCRUZ. Aerosol Cosmet., São Paulo, v. 60, 1989. Encarte técnico. 
147 MATALON, M. E., SANDINE, W. E. Improved media for differentiation of rods and cocci in yogurt. J. Dairy Sci., Champaing, v. 69, n. 10, p. 2569-2576, 1986.

148 MATTILA, T. A modified Kelsey-Sykes method for testing disinfectants with 2,3,5triphenyltetrazolium chloride reduction as an indicator of bacterial growth. J. Appl. Bacteriol., Oxford, v. 62, p. 551-554, 1987.

149 MATTSON, A. M., JENSEN, C. O., DUTCHER, R. A. Triphenyltetrazolium chloride as a dye for vital tissues. Science, London, v. 106, p. 294-295, 1947.

150 MAY, P. S., WINTER, J. W., FRIED, G. H., ANTOPOL, W. Effect of tetrazolium salts on selected bacterial species. Proc. Soc. Exp. Biol. Med., New York, v. 105, n. 2, p. 364-365, 1960.

151 MC CARTHY, J. A., THOMAS, Jr., H. A., DELANEY, J. E. Evaluation of the reability of coliform density tests. Amer. J. Pub. Health, Washington, v. 48, p. 1628-1635, 1958.

152 MC CONVIUE, J. F., ANGER, C. B., ANDERSON, Jr., D. W. Methods for performing aerobic plate counts of anhydrous cosmetics utilizing Tween 60 and Arlacel 80 as dispersing agents. Appl. Microbiol., Washington, v. 27, n. 1, p. 5$7,1974$.

153 MC KINNON, C. H., MANSELL, R. Rapid counting of bacteria in rinses of milking equipment by a membrane filtration - epifluorescent microscopy technique. J. Appl. Bacteriol., Oxford,v. 51, p. 363, 1981.

154 MEAD, G. C. A medium for the isolation of Streptococcus faecalis, sensu 'strictu. Nature, London, v. 197, p. 1323-1324, 1963. 
155 MEDZON, E. L, BRADY, M. L Direct measurement of acetylesterase in living protist cells. J. Bacteriol., Baltimore, v. 97, n. 1, p. 402-415, 1969.

156 MEШO, M. T., SILVA, N. P. M. The use of triphenyltetrazolium chloride in the study of dehydrogenase activity of Brucellae. Mem. Inst. Oswaldo Cruz, Rio de Janeiro,v. 53, n. 1, p. 45-53, 1955.

157 MERKEL, J. R., NICKERSON, W. J. Release of mitochondria from yeast cells by the action of metal-chelating agents. Proc. Natl. Acad. Sci. U S A, Washington, v. 39, p. 1008-1013, 1953.

158 MESSER, J. W., BEHNEY, H. M., LEUDECKE, L. O. Microbiology count methods. In: RICHARDSON, G. H. Standard methods for the examination of dairy products. 15. ed., Washington: American Public Health Association, 1985. p. 133- 140.

159 MICROBIAL contamination of medicines administered to hospital patients. Pharm. J., London, v. 207, p. 96-99, 1971. [ Report by Public Health Laboratory Service Working Party]

160 MORSE, L J., WIШAMS, H. L., GREEN, F. P. J., ELDRIDGE, E. E., ROTTA, J. R. Septicemia due to Klebsiella pneumoniae originating from hand-cream dispenser. N. Engl. J. Med., Boston, v. 277, n. 9, p. 472-473, 1967.

161 MUDD, S., BRODIE, A. F., WINTERSCHEID, L C., HARTMAN, P. E., BEUTNER, E. H., MC LEAN, R. A. Further evidence of the existence of mitochondria in bacteria. J. Bacteriol., Baltimore, v. 62, n. 6, p. 729-739, 1951. 
162 MUDD, S., WINTERSCHEID, L C., DELAMATER, E. D., HENDERSON, H. J. Evidence suggesting that the granules of mycobacteria are mitochondria. $J$. Bacteriol., Baltimore, v. 62, n. 4, p. 459-475, 1951.

163 MUSTAKAШO, K. K., AHOS, E. O., AUTO, E. O. Tetrazolium reduction. Test for milk. Science, London, v. 122, p. 971-972, 1955.

164 NEAL, C. E., CALBERT, H. E. The application of the 2,3,5-triphenyltetrazolium chloride test for inhibitory substances in milk. J. Dairy Sci., Champaing, v. 38, n. 6, p. $597,1955$.

165 NEAL, C. E., CALBERT, H. E. The use of 2,3,5-triphenyltetrazolium chloride as a test for antibiotic substances in milk. J. Dairy Sci.. Champaing, v. 38, n. 6, p. 629-633, 1955.

166 NEGRETTI, F. Caractteristiche batteriologiche dipreparazioni farmaceutiche presenti sul mercato italiano. II Farmaco - Ed. Prat, Pavia, v. 39, p. 20-28, 1984.

167 NICKERSON, W. J., MERKEL, J. R. A light activation phenomenon in the enzimatic and nonenzymatic reduction of tetrazolium salts. Proc. Natt. Acad. Sci. U S.A, Washington, v. 39, p. 901-905, 1953.

168 NOBLE, W. C., SAVIN, J. A. Steroid cream contaminated with Pseudomonas aeruginosa. Lancet, London, v. 1, n. 7433, p. 347-349, 1966.

169 OBLINGER, J. L, KENNEDY, J. E. Jr. Evaluation of diluents used for total counts. J. Milk Food Technol, Ames, v. 39, n.2, p. 114-116, 1976. 
170 OBLINGER, J. L, KOBURGER, J. A. The most probable number technique. In: AMERICAN PUBLC HEALTH ASSOCIATION. Technical Commiteo on Microbiological Methods for Foods. Compendium of methods for the microbiological examination of foods. 2. ed. Wasghinton, 1984. p. 99-111.

171 OBLINGER, J. L, KOBURGER, J. A. Understanding and teaching the most probable number technique. J. Milk Food Technol., Ames, v. 38, p. 540-545, 1975.

172 OGUR, M., JOHN, R., NAGAI, S. Tetrazolium overlay technique for population studies of respiration deficiency in yeast. Science, London, v. 125, n. 3254, p. 928-929, 1957.

173 OHARA, M. T., SATTO, T. Medicamentos não estéreis. III. Contaminação microbiana em suspensão aquosa de uso oral. Rev. Farm. Bioquím. Univ. S. Paulo, São Paulo, v. 21, n. 1, p. 71-79, 1985.

174 OHARA, M. T., FISCHER, D. C. H., SATTO, T. Contaminação microbiana em condicionadores de cabelos. Rev. Farm. Bioquím. S. Paulo, São Paulo, v. 27, n. 1, p. 28-36, 1991.

175 PAGANO, J., LEVIN, J. D., TREJO, W. Antibiotics Annual, 1957-1958, 137-143. Apud: RIOUX, J. A., BASTIDE, J. M., GALZY, P. La réduction des sels de tétrazolium par les levures: application a la détermination rapide de quelques especes du genne Candida. Trav. Pharm. Montpellier, Montpellier, v. 20, n. 1, p. $41-46,1960$.

176 PALMGREN, U., STROM, G., BLOMQUIST, G., MALMGERG, P. Collection of airborne micro-organisms on nuclepore filters, estimation and analysis CMNEA method. J. Appl. Bacteriol., Oxford, v. 61, p. 401-406, 1986. 
177 PALMIERI, J. M. FDA methodology for the microbial analysis of cosmetics and topical drugs. J. Soc. Cosmet. Chem., New York, v. 34, n. 1-2, p. 35-39, 1983.

178 PARK, C. K., MENDELOW, A. D., GRAHAM, D. I., MC CULLOCH, J., TEASDALE, G. M. Correlation of triphenyltetrazolium chloride perfusion staining with conventional neurohistology in the detection of early brain ischaemia. Neuropathol. Appl. Neurobiol., Oxford, v. 14, n. 4, p. 289-298, 1988.

179 PATEL, N. K., KOSTENBAUDER, H. B. Interaction of preservatives with macromolecules. I. Binding of parahydroxybenzoic acid esters by polyoxyethylene 20 sorbitan monooleate (Tween 80). J. Am. Pharm. Assoc. Sci. Ed., Washington, v. 47, p. 289-293, 1958.

180 PATON, A. M., JONES, S. M. The observation and enumeration of microorganisms in fluids using membrane filtration and incident fluorescence microscopy. J. Appl. Bacteriol., Oxford, v. 38, p. 199-200, 1975.

181 PEChMANN, H. V., RUNGE, P. Ber. Deutsch. Chem. Ges., 27, 2920, 1984. Apud: GUNZ, F. W. Reduction of tetrazolium salts by some biological agents. Nature, London, v. 163, n. 4133, p. 98, 1949.

182 PEDERSEN, E. A., SZABOL, L Microbial content in non-sterile pharmaceuticals. II. Methods. Dan. Tidsskr. Farm., Copenhagen, v. 42, n. 2, p. 50-55, 1968.

183 PEDERSEN, E. A., ULRICH, K. Microbial content in non-sterile pharmaceuticals. III. Raw materials. Dan. Tidsskr. Farm., Copenhagen, v. 42, p. 71-83, 1968. 
184 PEDRAL, M. M. E. R. Avaliação da eficiência do método de fluoresceína (soluçào de diacetato de fluoresceína e brometo de etídio) no estudo da viabilidade de células leveduriformes de Sportothrix schenckii. São Paulo. 198373 p. [ Dissertaão - Mestrado, Instituto de Ciencias Biomédicas - USP ].

185 PEELER, J. T., GILCHRIST, J. E., DONNELIY, C. B., CAMPBEL, J. E. A collaborative study of the spiral plate method for examining milk samples. J. Food Prot., Ames, v. 40, p. 462- 464, 1977.

186 PERSONNÉ, J. C., ESTEVE, G., LOZANO, F. La propreté microbiologique des préparations pharmaceutiques et cosmetiques: position du Laboratorie National de la Santé . Labo-Pharma - Prob. Tech., Paris, v. 25, n. 270, p. 885-890, 1977.

187 PETTIPHER, G. L, MANSELL, R., MACKINNON , C. H., COUSINS, C. M. Rapid membrane filtration - epifluorescent microscopy technique for direct enumeration of bacteria in raw milk. Appl. Environ. Microbiol., Washington, v. 39, n. 2, p. 423-429, 1980.

188 PETTIPHER, G. L, RODRIGUES, U. M. Rapid enumeration of microorganisms in foods by the direct epifluorescent filter technique. Appl. Environ. Microbiol., Washington, v. 44, p. 809-813, 1982.

189 PHARMACOPÉE française. 8. ed., Paris: Comission Permanent de La Pharmacopée par L'ordre National des Pharmaciens. 1965.

190 PHARMACOPOEA internationalis. Especificaciones de la calidad de las preparaciones farmaceuticas. 2. ed. Ginebra, Organización Mundial de la Salud, 1970. p. XXXV. 
191 PHIUUS, I. Postoperative respiratory-tract infection with Pseudomonas aeruginosa due to contaminated lignocaine jelly. Lancet, London, v. 1, n. 7443, p. 903-904, 1966.

192 PINDER, A. C., PURDY, P. W., POUTER, S. A. G., CLARK, D. C. Validation of flow cytometry for rapid enumeration of bacterial concentrations in pure cultures. $J$. Appl. Bacteriol., Oxford, v. 69, n. 1, p. 92-100, 1990.

193 PISANO, F. D., KOSTENBAUDER, H. B. Interaction of preservatives with macromolecules. II. Correlation of binding data with required preservative concentrations of p-hydroxybenzoates in the presence of Tween 80 . J. Am. Pharm. Assoc. Sci. Ed., Washington, v. 49, p. 310-314, 1959.

194 PLAZA, C. J., de la ROSA, M. C., ARRIBAS, M. L G., MOSSO, M. A. Importance de la méthode utilisée pour le controle microbiologique de médicaments â usage topique. Pharm. Acta Helv., Zurich, v. 62, n. 2, p. 48-52, 1987.

195 POELMAN, M. C., PUISIEUX, F., CHAUMEIL, J. C. Les interactions entre antiseptiques et surfactifs. III. E'tude de l'interaction parahydroybenzoate de methyle-esters de sorbitanne polyoxyéthylénés par une méthode de dialyse. Ann. Pharm. Fr., Paris, v.33, p. 693-699, 1975.

196 PRATT, R., DUFRENOY, J. Stain Tech., 1948, 23, 137. Apud: FRED, R. B., KNIGHT, S. G. The reduction of 2,3,5-triphenyltetrazolium chloride by Penicillium chrysogenum. Science, London, v. 109, p. 169-170, 1949.

197 PUNCH, J. D., OLSON Jr., J. C. Comparison between standard methods procedure and a surface plate method for estimating psychrophilic bacteria in milk. J. Milk Food Technol., Ames, v. 27, p. 43-47, 1964. 
198 QUEIROZ, D. M., MENDES, E. N., ROCHA, G. A. Indicator medium for isolation of Campylobacter pylori. J. Clin. Microbiol., Washington, v. 25, n. 12, p. 2378 2379, 1987.

199 RAMIREZ-PONCE, M. P., RAMIREZ, J. M., GALLEGO, G. G. Rhodoquinone as a constituent of the dark electron-transfer system of Rhodospirillum rubrum. FEBS Lett., Amsterdam, v. 119, n. 1, p. 137-140, 1980.

200 RAMSDEL, G. A., JOHNSON, W. M. T., EVANS, F. R. Investigation of the resazurin as an indicator of the sanitary condition of milk. J. Dairy Sci., Champaing, v. 18, n. 11, p. 705-717, 1935.

201 RAUT, C. A cytochrome deficient mutant of Sacharomyces cerevisiae. Exp. Cell Res., New York, v. 4, n. 2, p. 295-305, 1953.

202 RAY, B., ADAMS Jr., D. M. Repair and detection of injured microorganisms. In: AMERICAN PUBLC HEALTH ASSOCIATION. Technical Committee on Microbiological Methods for Foods. Compendium of methods for the microbiological examination of foods. 2. ed., Washington, 1984. p. 112-123.

203 RAY, B., SPECK, M. L Discrepancies in the enumeration of Escherichia coli. Appl. Microbiol., Washington, v. 25, p. 494-498, 1973.

204 RAY, B., SPECK, M. L Discrepancies in the enumeration of Escherichia coli. Appl. Microbiol., Washington, v. 25, p. 494-498, 1973.

205 REID, F. R., WOOD, T. O. Pseudomonas comeal ulcer. The causative role of contaminated eye cosmetics. Arch. Ophthalmol., Chicago, v. 97, p. 1640-1641, 1979. 
206 RIBEIRO, L. M., HERR, S., PEFANIS, S. M., GOUS, A. G. The use of sensitivity discs in the identification of Campylobacter species. Onderstepoort J. Vet. Res., Pretoria, v. 57, n. 2, p. 129-131, 1990.

207 RIESEN, V. Digetion of algin by Pseudomonas maltophilia and Pseudomonas putida. Appl. Environ.Microbiol., Washington, v. 39, n. 1, p. 92-95, 1980.

208 RINGERTZ, O., RINGERTZ, S. The clinical significance of microbial contamination in pharmaceutical and allied products. Adv. Pharm. Sci., London, v. 5., p. 211226, 1982.

209 RIOUX, J. A., BASTIDE, J. M., GALZY, P. La réduction des sels de tétrazolium par les levures: application a la détermination rapide de quelques espêces du genre Candida. Trav. Pharm. Montpellier, Montpellier, v. 20, n. 1. p. 41-46, 1960.

210 ROBINSON, E. P. Pseudomonas aeruginosa contamination of liquid antiacids. A survey. J. Pharm. Sci., Washington, v. 60, p. 604-605, 1971.

211 RODRIGUES, U. M., KROL, R. G. Use of the direct epifluorescent filter technique for the enumeration of yeasts. J. Appl. Bacteriol., Oxford, v. 61, n. 2, p. 139-144, 1986.

212 RODRIGUES, U. M., KROL, R. G. Rapid selective enumeration of bacteria in foods using a microcolony epifluorescence microscopy technique. J. Appl. Bacteriol., Oxford, v. 64, n. 1, p. 65-78, 1988.

213 ROMOND, C. Aspect technologique des controles microbiologiques des médicaments, des aliments et des cosmétiques. Labo-Pharm. Probl. Tech., Paris, v. 25, n. 267, p. 543-547, 1977. 
214 RUSSEL, A. D., AHONKHAl, I., ROGER, D. T. Microbiological applications of the inactivation of antibiotics and other antimicrobial agent. J. Appl. Bacteriol., Oxford, v. 46, p. 207-245, 1979.

215 RUSSEL, M. Microbiological control of raw materials. In: BLOOMFIELD, S. F., BAIRD, R., LEAK, R. E., LEECH, R. Microbiological quality assurance in pharmaceuticals, cosmetics and toletries. Chichester: Ellis Horwood. 1988. p. 35-48.

216 SCOTT, H. Methods for counting and testing for micro-organisms in raw materials, topical and oral products. J. Soc. Cosmet. Chem., New York, v. 24, p. 65-78, 1973.

217 SELIGMAN, A. M., RUTENBURG, A. M. The histochemical demonstration of succinic dehydrogenase. Science, London, v. 113, n. 2934, p. 317-320, 1951.

218 SENTERFT, L B., JENSEN, K. E. Antimetabolic antibodies to Mycoplasma pneumoniae measured by tetrazolium reduction inhibition. Proc. Soc. Exp. Biol. Med., New York, v. 122, n. 2, p. 786-790, 1966.

219 SEVAG, M. G., FORBES, M. Oxidative interaction between glucose and nitrogenous substances. Arch. Biochem., New York, v. 29, n. 1, p. 229-230, .

220 SEVITT, S. Source of two-hospital infected cases of tetanus. Lancet, London, v.2, n. 6589, p. $1075-1078,1949$.

221 SIEGEL, S. Estatística não paramétrica para ciências do comportamento. São Paulo: Mac Graw Hill, 1981. 350 p. 
222 SLANETZ, L W., BENT, D. F., BARTLEY, C. H. Publ. Health Rep. Wash., 70, (1), 67 (1955). Apud: MEAD, G. C. A medium for the isolation of Streptococcus faecalis, sensu strictu. Nature, London, v. 197, n. 4874, p. 1323-1324, 1963.

223 SMIDT, B. F., ULRICH, K. Microbial content in non-sterile pharmaceuticals. V. Tablets. Dan. Tidsskr. Farm., Copenhagem, v. 42, n. 9, p. 257-263, 1968.

224 SMTH, F. E. Tetrazolium salt. Science, London, v. 113, p. 751-754, 1951.

225 SPOONER, D. F. Hazards associated with the microbiological contamination of non-sterile pharmaceuticals, cosmetics and toiletries. In: BLOOMFIELD, S. F., BAIRD, R. , LEAK, R. E., LEECH, R. Microbial quality assurance in pharmaceuticas, cosmetics and toiletries. Chichester: Ellis Horwood, 1988. p. 15-33.

226 SPOONER, D. F. Microbiological aspects of the EEC directive . Cosmet. Toiletries, Oak Park, v. 92, n. 9, p. 42-51, 1977.

227 STEIN, R. J., GERARDE, H. W. Triphenyltetrazolium chloride in tissue culture. Science, London, v. 111, n. 2895, p. 691, 1950.

228 STRAKA, R. P., STOKES, J. L Rapid destruction of bacteria in commonly used diluents and its elimination. Appl. Microbiol., Washington, v. 5, n. 1, p. 21-24, 1957.

229 STRAUS, F. H., CHERONIS, N. D., STRAUS, E. Demonstration of reducing enzyme systems in neoplams and living mammalian tissues by triphenyltetrazolium chloride. Science, London, v. 108, n. 2796, p. 113-115, 1948. 
230 TAGLIAPIETRA, L La qualitá microbiologica nei prodotti farmaceutici non obbligatoriamente sterili. Boll. Chim. Farm., Milano, v. II7, p. 1-13, 1978.

231 TENENBAUM, S. Considerations leading to the development of the microbial limit guidelines of the CTFA. Cosmet. Toiletries, Oak Park, v. 92, n. 3, p. 79-83, 1977.

232 TENENBAUM, S. Microbiological limit guidelines for cosmetics and toiletries. The cosmetic, toiletry and fragrance association. Cosmet. J., v. 4, p. $25-31,1973$. Apud: MC CONVILE, J. F., ANGER, C. B., ANDERSON Jr., D. W. Methods for performing aerobic plate counts of anhydrous cosmetics utilizaing Tween 60 and Arlacel 80 as dispersing agents. Appl. Microbiol. , Washington, v. 27, n. 1, p. 5-7, 1974.

233 TENGERDY, R. P., NAGY, J. G., MARTIN, B. Quantitative measurement of bacterial growth by the reduction of tetrazolium salts. Appl Microb., Baltimore, v. 15, n. 3 , p. 954-955, 1967.

234 THE INTERNATIONAL COMMISSION ON MICROBIOLOGICAL SPECIFICATIONS FOR FOODS (ICMSF) of the International Union of Microbiological Societies. Microorganisms in foods. 2 Sampling for microbiological analysis: principles and specific applications. 2. ed. Toronto: University of Toronto Press, 1986. p. 293.

235 THE INTERNATIONAL pharmacopoeia. 3. ed. Geneva: World Health Organization, 1979. v. 1.

236 THE UNITED States pharmacopeia. 12. ed. Easton: Mack, 1942.

237 THE UNITED States pharmacopeia. I3. ed. Easton: Mack, 1947. 
238 THE UNTTED States pharmacopeia. 14. ed. Easton: Mack, 1950.

239 THE UNITED States pharmacopeia. 15. ed. Easton: Mack, 1955.

240 THE UNITED States pharmacopeia. 16. ed. Easton: Mack, 1960.

241 THE UNITED States pharmacopeia. 17. ed. Easton: Mack, 1965.

242 THE UNITED States pharmacopeia. 18. ed. Easton: Mack, 1970.

243 THE UNITED States pharmacopeia. 19. ed. Rockville: The United States Pharmacopeial Convention, 1975.

244 THE UNTTED States pharmacopeia. 20. ed. Rockville: The United States Pharmacopeial Convention, 1980.

245 THE UNITED States pharmacopeia. 21. ed. Rockville: The United States Pharmacopeial Convention, 1985.

246 THE UNTTED States pharmacopeia. 22. ed. Rockville: The United States Pharmacopeial Convention, 1990.

247 TOMASIEWICZ, D. M., HOTCHKISS, D. T., REINBOLD, G. W., READ, R. B., HARTMAN, P. A. The most suitable number of colonies on plates for counting. J. Food Prot., Ames, v. 43, p. 282-286, 1980.

248 TREMEWAN, H. C. Tetanus neonatorum in New Zealand. New Zealand Med. J., v. 45, p. 312-313, 1946. Apud: BRUCH, C. W. Objectionable micro-organisms in non-sterile drugs and cosmetics. Drug Cosmet. Ind., New York, v. 111, n. 3, p. 51-54, 150-156, 1968. 
249 TSUJI, K., STAPERT, E. M., ROBERTSON, J. H., WAYYAKI, P. M. Sterility test method for petrolatum-based ophthalmic ointments. Appl. Microbiol., Washington, v. 20, p. 798, 1970.

250 TURAKKA, L, OJANEN, T., PRITTINEN, T. Microbiological purity testing of semisolid topical preparations. Pharmazie, Berlin, v. 41, p. 254-256, 1986.

251 TURNER, N., SANDINE, W. E., ELIKER, P. R., DAY, E. A. Use of tetrazolium dyes in an agar medium for differentiation of Streptococcus lactis and Streptococcus cremoris. J. Dairy Sci., Champaing, v. 46, p. 380-385, 1963.

252 ULRICH, K., FUGLSANG-SMIDT, B., HASTRUP, B., HANSEN, H., FISCHER, A. Microbial content in non-sterile pharmaceuticals. VII. Topical preparations. Dan. Tidsskr. Farm., Copenhagen, v. 45, p. 39-47, 1971.

253 USDIN, E., SHOCKMAN, G. E. D., TOENNIES, G. Tetrazolium bioautography. Appl. Microbiol., Washington, v. 2, n. 1, p. 29-33, 1954.

254 VAN ABBÉ, N. J., DIXON, H., HUGHES, O., WOODROFFE, R. C. S. The hygienic manufacture and preservation of toiletries and cosmetics. J. Soc. Cosmet. Chem., New York, v. 21, p. 719-800, 1970.

255 VANDERZANT, C., MATTHYS, A. W. Effect of temperature of the plating medium on the viable count of psychrophilic bacteria. J. Milk Food Technol, Ames, v. 28, p. 383-388, 1965.

256 WACHI, Y., YANAGI, M., KATSURA, H., OHTA, S. Decomposition of surfac-active agents by some bacteria isolated from deionized water. J. Soc. Cosmet. Chem., New York, v. 3l, n. 3-4, p. 67-84, 1980. 
257 WEBER, G. R., BLACK, L A. Inhibitors for neutralizing the germicidal action of quaternary ammorium compounds. Soap Sanit. Chem., New York, v. 24, p. 137-151, 1948.

258 WEIBULL, C. Observations on the staining of Bacillus megaterium with triphenyltetrazolium. J. Bacteriol., Baltimore, v. 66, n. 2, p. 137-139, 1953.

259 WESTWOOD, N. Microbial contamination of some pharmaceutical raw materials. Pharm. J., London, v. 207, n. 5622, p. 99-103, 1971.

260 WILSON, L A., AHEARN, D. G. Pseudomonas induced comeal ulcers associated with contaminated eye mascaras. Am. J. Ophtha/mol., Chicago, v. 84, p. $112-$ $119,1977$.

261 WOOD, R. M. Brucella ring test antigen prepared by reduction of a tetrazolium salt. Science, London, v. 112, n. 2899, p. 86, 1950.

262 WOODS, L L, SMTH, T. F. Tetrazolium agar overlay in test for Mycoplasma pneumoniae. Appl. Microbiol., Washington, v. 24, n. 1, p. 148-149, 1972.

263 WORLD HEALTH ORGANIZATION. Microbiological contamination of nonsterile drugs. WHO/PHARM/69453. 10 p. [ mimeogr.]

264 WRIGHT, E. O., REINBOLD, G. W., BURMEISTER, L, MELLON, J. Prediction of standard plate count of manufacturing-grade raw milk from the plate loop count. J. Milk Food Technol., Ames, v. 33, p. 168-170, 1970.

265 ZAMENHOF, S. Gene unstabilization. Induced by heat and nitrous acid. J. Bacteriol., Baltimore, v. 81, p. 111-114, 1961. 
266 ZIEGLER, N. R., HALVORSON, H. O. Application of statistics to problems in bacteriology. IV. Experimental comparison of the dilution method, the plate count, and the direct count for the determination of bacterial populations. $J$. Bacteriol., Baltimore, v. 29, p. 609-633, 1935.

267 ZIMMERMANN, R., ITURRIAGA, R., BECKER-BIRCK, J. Simultaneous determination of the total number of aquatic bacteria and the number thereof involved in respiration. Appl. Environ. Microb., Washington, v. 36, n. 6, p. 926$935,1962$.

268 ZWOLSKAKWIEK, Z. Usefulness of tetrazole salts for investigting the reducing ability of bacili . Gruzlica, v. 42, n. 1, p. 75-83, 1974. Apud: Chem. Abstr., Columbus, v. 81, n. 60633r, 1974.

269 ZYGMUNT, W. A. Inhibition of antibiotic formation by bromthymol blue and other indictors in Strptomyces rimosus. Nature, London, v. 195, p. 1102, 1962. 


\section{RESUMO}

O cloreto de trifeniltetrazólio (TTC) foi empregado neste trabalho visando padronização de método altemativo para o teste de limite microbiano em medicamentos e cosméticos, com redução no tempo de análise, além de possibilitar a aplicação da técnica de semeadura em profundidade em amostras hidroinsolúveis com opacidade e carga contaminante menor que $10^{2} \mathrm{UFC} / \mathrm{g}(\mathrm{mL})$. Na técnica de tubos múltiplos, a aplicação do corante não possibilitou a redução do tempo de incubação, pois a sensibilidade para detecção de suspensão bacteriana por meio de coloração do trifenilformazano foi de $10^{8} \mathrm{UFC} / \mathrm{mL}$ após 1 hora de reação e $10^{7} \mathrm{UFC} / \mathrm{mL}$ após 4 horas, suspensões estas visivelmente turvas. A adição de glicose e ácido glutâmico no meio de caseina-soja, nas concentrações de $0,5 \%$ e $0,1 \%$, respectivamente, não aumentou a sensibilidade da reação. 0 polissorbato 20 , adicionado ao meio de cultura, líquido ou sólido, promoveu a difusão do trifenilformazano das células para o meio, fator que não favorece a visualização da massa celular no meio líquido e nem das colônias. A concentração mínima de TTC que resultou em coloração máxima no meio líquido foi de 500 e $1000 \mu \mathrm{g} / \mathrm{mL}$, dependendo da espécie bacteriana. Entretanto, suspensões bacterianas com 102, 10 e $1 \mathrm{UFC} / \mathrm{mL}$ testadas, pela técnica de tubos multiplos, com adição do corante na forma de solução após 20 horas em meio de caseina-soja, forneceram resultados equivalentes, quanto ao número de tubos positivos e negativos frente às duas concentrações . A comparação desta técnica alternativa com a da subcultura demonstrou ser o tempo de 20 horas de incubação insuficientes para detecção pelo TTC, quando inoculadas alíquotas de $1 \mathrm{~mL}$ de suspensão com número da ordem de $1 \mathrm{UFC} / \mathrm{mL}$ Na técnica de semeadura em profundidade, após incubação de 48 horas, a coloração das colônias bacterianas foi efetuada cobrindo-se a superfície do meio de cultura com $5 \mathrm{~mL}$ de ágar a 1,0\% contendo TTC. A concentração de 0,025\% do corante promoveu a coloração das colônias após 1 hora. Entretanto, na presença de suspensão de hidróxido de aluminio a $6 \%$ a concentração mínima eficaz de TTC foi de $0,1 \%$. Para leveduras em meio líquido essa concentração foi de $2.500 \mu \mathrm{g} / \mathrm{mL}$ no 
meio neutralizado. Em meio sólido, na presença de material opalescente, a concentração eficaz foi de 2,0\%, com o TTC adicionado na dispersão de ágar em tampão pH 7,5. Amostras de produtos comercializados com característica opalescente foram submetidas à análise pelo método de tubos múltiplos com sub-cultura e pela revelação com TTC. Simultaneamente as mesmas foram testadas pelo método de semeadura em profundidade, inoculando-se $2 \mathrm{~mL}$ das diluições 1:4 e 1:10 com revelação das colônias com o corante. O tempo para obtenção dos resultados foi de 72 horas pelo método oficial e de 50 horas pelo método com TTC, tanto em meio líquido como em sólido. A comparação dos dados obtidos pelos 3 métodos não resultou em diferença significativa para a maioria das amostras testadas. Entretanto, os coeficientes de variação foram sempre menores para o método de semeadura em profundidade com a amostra diluída de 1:4, indicando maior precisão deste sobre os outros, principalmente em relação ao número mais provável. 


\section{ABSTRACT}

The conventional methods for bioburden assessment are restrictive when applied to evaluate microbiological quality of pharmaceuticals and cosmetics. Triphenyltetrazolium chloride (TTC) was applied in this standartization study as alternative method for microbial limit test of pharmaceuticals and cosmetics. This method aimed at to reduce the assay time by conciliating the pour-plate technique analysis low bioburden of samples containing opacifiers. The application of this dye in the multiple tubes technique did not reduce incubation time, because the bacterial suspension sensitivity to triphenylformazan colour was $10^{8} \mathrm{CUF} / \mathrm{mL}$ to 1 hour reaction and $10^{7} \mathrm{CUF} / \mathrm{mL}$ to 4 hours. Suspensions with these bioburden are clearly turbid. The addition of $0.5 \%$ glicose and $0.1 \%$ glutamic acid to soybean-casein digest medium did not increase the reaction sensitivity. The addition of polissorbate 20 to solid or liquid media promotted the difusion of triphenylformazan from the cells to media; it rendered difficult of cellular mass detection in liquid medium and as much as colonies. The minimum concentration of TTC that produced maximum colour in liquid medium was 500 and $1,000 \mu \mathrm{g} / \mathrm{mL}$, depending on the bacteria. However, bacterial suspensions with $10^{2} \mathrm{CUF} / \mathrm{mL}$ tested by multiple tubes technique with 20 hours of incubation and by microbial growth detection after TTC addition provided equivalent numbers of positive and negative tubes with both concentrations. The comparison of this alternative method with that of sub-culture proved that 20 hours of microbial growth is not enough to be detected by TTC, when $1 \mathrm{~mL}$ of $1 \mathrm{CUF} / \mathrm{mL}$ suspension was planted. The dying of bacterial colonies was performed by covering the medium surface with $5 \mathrm{~mL}$ of $1 \%$ agar with TTC, molten at $48 \mathrm{C}$. The concentration of TTC that colored colonies in 1 hour was $0.025 \%$. However, in presence of $6 \%$ aluminium hidroxide suspension the minimum effective concentration was $0.1 \%$. The concentration required to detect yeasts in liquid media was $2,500 \mu \mathrm{g} / \mathrm{mL}$ in neutral $\mathrm{pH}$ condition. To detect yeast colonies in opalescent solid medium effective TTC concentration was $2 \%$; in this case the dye was added to agar dispersed in 7.5 phosfate buffer. Samples of marketed produtcts were analysed through multiple tubes method with sub-culture and by TTC addition. Same samples 
were tested through pour-plate technique by inoculating $2 \mathrm{~mL}$ of $1: 4$ and $1: 10$ dilutions. The time required for results was 72 hours by the official method and 50 hours by alternative proposed method in liquid or solid medium. When the 3 method results were compared no significant differences were observed in almost all of the samples. However, the coefficient of variation related to pour-plate method results from 1:4 sample dilution was always lower than the others, mainly when compared with those obtained from multiple tubes method. Therefore, the alternative pour-plate method is the most accurate one. 